\title{
Synthesis of a Diastereomer of the Marine Macrolide Lytophilippine A
}

\author{
Supporting Information \\ Part 1 \\ André Klüppel, Annika Gille, Ceren Ester Karayel and Martin Hiersemann* \\ Fakultät für Chemie und Chemische Biologie \\ Technische Universität Dortmund \\ 44227 Dortmund, Germany \\ martin.hiersemann@tu-dortmund.de
}

\section{Table of Contents}

$\begin{array}{ll}\text { SI-1-1 } & \text { Materials and Methods } \\ \text { SI-1-2 } & \text { List of Abbreviations } \\ \text { SI-1-3 } & \text { Synopsis } \\ \text { SI-1-8 } & \text { Procedures and Characterization } \\ \text { SI-1-49 } & { }^{1} \text { H NMR Mosher Ester Analyses } \\ \text { SI-1-51 } & { }^{13} \text { C NMR Acetonide Analyses } \\ \text { SI-1-52 } & { }^{1} \text { H and }{ }^{13} \text { C NMR Comparison with Rezanka and Lee } \\ \text { SI-1-60 } & \text { References }\end{array}$

\section{Materials and Methods}

Unless otherwise stated, all moisture-sensitive reactions were performed in flame-dried septum-sealed glassware under an atmosphere of argon. Commercially available reagents, catalysts and solvents were used as purchased. Toluene (PhMe), tetrahydrofuran (THF), dichloromethane $\left(\mathrm{CH}_{2} \mathrm{Cl}_{2}\right)$, diethyl ether $\left(\mathrm{Et}_{2} \mathrm{O}\right)$ and acetonitrile $(\mathrm{MeCN})$ were dried deploying the commercially available MBraun MB SPS 800 solvent purification system. Molecular sieves were activated by heating (220 to $240{ }^{\circ} \mathrm{C}$ ) under reduced pressure $\left(5 \cdot 10^{-2} \mathrm{mbar}\right)$ for $3 \mathrm{~h}$. Triethylamine and diisopropylamine were distilled from activated $4 \AA$ molecular sieves and stored under an atmosphere of argon. Pyridine and $n$-hexane were distilled from activated $4 \AA$ molecular sieves and stored under an atmosphere of argon over activated $4 \AA$ molecular sieves. Methanol $(\mathrm{MeOH})$ was distilled from magnesium and stored under an atmosphere of argon over activated $4 \AA$ molecular sieves. IBX was prepared according to the literature and stored in the refrigerator. ${ }^{1}$ TBSOTf was prepared according to the literature and stored in the freezer. ${ }^{2}$ Aqueous phosphate buffer $(\mathrm{pH} 7)$ was prepared by addition of aqueous sodium dihydrogen phosphate $(0.1 \mathrm{M}$ $\left.\mathrm{NaH}_{2} \mathrm{PO}_{4}, 433 \mathrm{~mL}\right)$ to aqueous sodium hydrogen phosphate $\left(0.1 \mathrm{M} \mathrm{Na}_{2} \mathrm{HPO}_{4}, 1000 \mathrm{~mL}\right) . \mathrm{CDCl}_{3}$ was stored over activated $4 \AA$ molecular sieves. Reagents were transferred by means of syringe. Solids were introduced under a counter-flow of argon. Analytical TLC was performed using precoated silica gel foils type $60 \mathrm{~F}_{254}(4 \mathrm{~cm})$. Visualization was achieved using $254 \mathrm{~nm}$ ultraviolet irradiation followed by staining with the Kägi-Miescher reagent ( $p$-anisaldehyde $2.53 \% v / v$, acetic acid $0.96 \% v / v$, ethanol $93.06 \% v / v$, conc. $\left.\mathrm{H}_{2} \mathrm{SO}_{4} 3.45 \% \mathrm{v} / \mathrm{v}\right)$ or the $\mathrm{KMnO}_{4}$ reagent: $\mathrm{KMnO}_{4}(3 \mathrm{~g}), \mathrm{K}_{2} \mathrm{CO}_{3}(20 \mathrm{~g}), \mathrm{NaOH}(0.25 \mathrm{~g}$ in $5 \mathrm{~mL}$ $\left.\mathrm{H}_{2} \mathrm{O}\right), \mathrm{H}_{2} \mathrm{O}(300 \mathrm{~mL}){ }^{3}$ Chromatographic purification ${ }^{4}$ was performed on silica gel (particle size $0.040-0.063 \mathrm{~mm})$. Mixtures of cyclohexane and ethyl acetate, $n$-pentane and diethyl ether or dichloromethane and methanol were used as eluents. ${ }^{1} \mathrm{H}$ NMR spectra were recorded at 300, 400, 500, 600 or $700 \mathrm{MHz}$. Chemical shifts $(\delta)$ are reported in ppm relative to $\mathrm{CDCl}_{3}(7.26 \mathrm{ppm})$ or $\mathrm{CD}_{3} \mathrm{OD}(3.31 \mathrm{ppm})$, unless stated otherwise. ${ }^{5}$ Signal splitting patterns are labeled by the following abbreviations: br. $\mathrm{s}=$ broad singlet, $\mathrm{s}=$ singlet, $\mathrm{d}=$ doublet, $\mathrm{t}=$ triplet, $\mathrm{q}=$ quartet, quin $=$ quintet, $\mathrm{sxt}=$ sextet, $\mathrm{m}=$ multiplet or overlap of nonequivalent resonances. Coupling constants $(\mathrm{Hz})$ are given as reported by the NMR processing and analysis software. ${ }^{13} \mathrm{C}$ NMR spectra were recorded at 75, 101, 126, 151 or $176 \mathrm{MHz}$. 
Unless otherwise reported all ${ }^{13} \mathrm{C}$ NMR spectra were obtained with broadband proton decoupling. Chemical shifts are reported in ppm relative to $\mathrm{CDCl}_{3}(77.16 \mathrm{ppm})$ or $\mathrm{CD}_{3} \mathrm{OD}(49.00 \mathrm{ppm})$; the total number of reported ${ }^{13} \mathrm{C}$ atom signals may fall short of the expected number because of coincidental chemical shifts, even for constitutopic or diastereotopic carbon atoms. ${ }^{19} \mathrm{~F}$ NMR spectra were recorded at 471 or $565 \mathrm{MHz}$. Chemical shifts are reported in ppm. The NMR peak assignment rests on the interpretation of ${ }^{13} \mathrm{C}$ DEPT, ${ }^{1} \mathrm{H}^{1} \mathrm{H}$ COSY, ${ }^{1} \mathrm{H}^{1} \mathrm{H}$ NOESY, ${ }^{1} \mathrm{H}^{13} \mathrm{C} \mathrm{HSQC}$ and ${ }^{1} \mathrm{H}^{13} \mathrm{C}$ HMBC experiments. Unless stated otherwise, IR spectra were recorded on a Nicolet Avatar E.S.P. as a thin film on a KBr disk or on a Bruker Tensor 27 spectrometer (PLATINUM Diamond ATR). Infrared absorptions are reported in reciprocal wavelength $v\left(\mathrm{~cm}^{-1}\right)$ and are adjusted down- or upward to 0 or $5 \mathrm{~cm}^{-1}$. Relative intensities are indicated as they appear using the following abbreviations: $\mathrm{s}=$ strong, $\mathrm{m}=$ middle, $\mathrm{w}=$ weak . Molecular formula assignment was confirmed by combustion elemental analysis using the elemental analyzers Leco CHNS-932 or Elementar Vario Micro Cube. Low resolution mass spectra (LRMS) were recorded on a Acquity QDa Detector coupled to a Waters Alliance e2695 Separations Module. High resolution mass spectra (HRMS) were recorded on a LTQ Orbitrap (Thermo Electron) or on a Bruker timsTOF mass spectrometer using electrospray ionization (ESI). Optical rotations were measured with an A. Krüss Optical polarimeter operating on the sodium D-line $(589 \mathrm{~nm})$ using a quartz glass cuvette $(1 \mathrm{~mL})$ and are reported as: $[\alpha]_{\mathrm{D}}{ }^{\mathrm{T}}$ (concentration in $\mathrm{g} / 100 \mathrm{~mL}$, solvent). Melting points (m.p.) are uncorrected and were recorded on a Büchi B-540 or a Büchi M-560 melting point apparatus.

Abbreviations (in order of their appearance)

DEPT
COSY
NOESY
HSQC
HMBC
MsCl
NaHMDS
IBX
DMSO
cont.
MOMCl
DIPEA
DMAP
DIBAL-H
LDA
conc.
D-(-)-DIPT
MS
TBHP
CSA
MTPA-Cl
PTSA
MNBA
TBSOTf
DDQ
DMS
TfOH
BnCl
TBAI
DIPA

Distortionless Enhancement by Polarization Transfer Correlation Spectroscopy Nuclear Overhauser Effect Spectroscopy Heteronuclear Single Quantum Correlation Heteronuclear Multiple Bond Correlation methanesulfonyl chloride sodium bis(trimethylsilyl)amide 2-iodoxybenzoic acid dimethyl sulfoxide contaminated chloromethyl methyl ether $\mathrm{N}, \mathrm{N}$-diisopropylethylamine 4-(dimethylamino)pyridine diisobutylaluminium hydride lithium diisopropylamide concentrated

(-)-diisopropyl $D$-tartrate molecular sieve tert-butyl hydroperoxide

(1S)-(+)-10-camphorsulfonic acid $\alpha$-methoxy- $\alpha$-(trifluoromethyl)phenylacetyl chloride $p$-toluenesulfonic acid

2-methyl-6-nitrobenzoic anhydride tert-butyldimethylsilyl trifluoromethanesulfonate

2,3-dichloro-5,6-dicyano- $p$-benzoquinone dimethyl sulfoxide

trifluoromethanesulfonic acid benzyl chloride

tetrabutylammonium iodide diisopropylamine
$\mathrm{MeSO}_{2} \mathrm{Cl}$

$\left(\mathrm{Me}_{3} \mathrm{Si}\right)_{2} \mathrm{NNa}$

$\mathrm{Me}_{2} \mathrm{SO}$

$\mathrm{ClCH}_{2} \mathrm{OCH}_{3}$ $(i \text {-Pr })_{2} \mathrm{NEt}$

$(i-\mathrm{Bu})_{2} \mathrm{AlH}$

$(i-\mathrm{Pr})_{2} \mathrm{NLi}$

$\mathrm{Me}_{3} \mathrm{COOH}$

$\mathrm{Me}_{2} \mathrm{~S}$

$\mathrm{CF}_{3} \mathrm{SO}_{3} \mathrm{H}$

$(n-\mathrm{Bu})_{4} \mathrm{NI}$

$(i-\mathrm{Pr})_{2} \mathrm{NH}$ 
Synthesis of a Diastereomer of the Marine Macrolide Lytophilippine A

\section{Synopsis (continued...)}

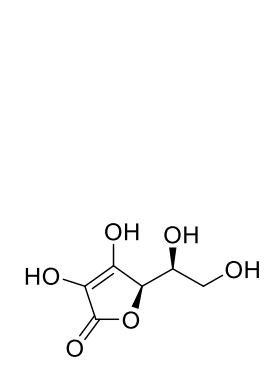

$(+)-\mathbf{S 1}$

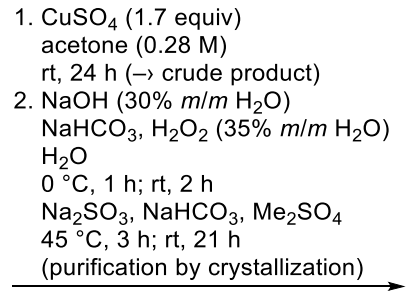

$76 \%(12.33 \mathrm{~g})$ chromatographic purification not required

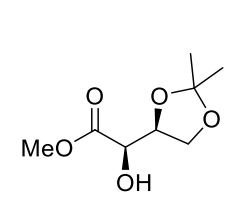

$(+)-S 2$ $\mathrm{dr} \geq$ 95:5(NMR)
$\mathrm{MsCl}$ (1.2 equiv), $\mathrm{Et}_{3} \mathrm{~N}$ (1.3 equiv) $\mathrm{CH}_{2} \mathrm{Cl}_{2}(0.33 \mathrm{M})$

(purification by crystallization)

$85 \%(14.87 \mathrm{~g})$

chromatographic purification

not required

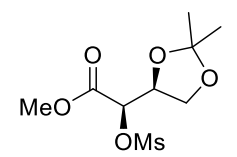

(+)-S3

$\mathrm{dr} \geq 95: 5$ (NMR)

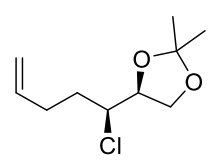

(-)-S6 $\mathrm{dr} \geq 95: 5$ (NMR)
$\mathrm{Cl}_{2} \mathrm{C}=\mathrm{NMe}_{2} \mathrm{Cl}$ ( 1.3 equiv) pyridine (5 equiv) $\mathrm{CH}_{2} \mathrm{Cl}_{2}(0.25 \mathrm{M})$

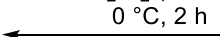

$85 \%(12.69 \mathrm{~g})$

contaminated with ca. $8 \%$ impurities

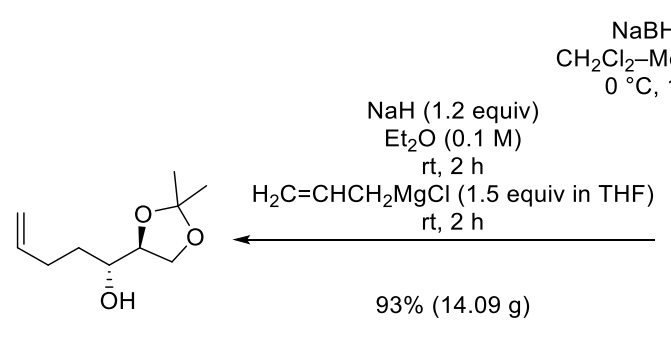

(-)-S5 $\mathrm{dr} \geq$ 95:5 (NMR)

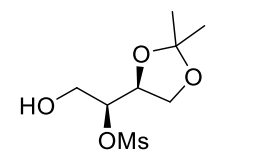

(-)-S4

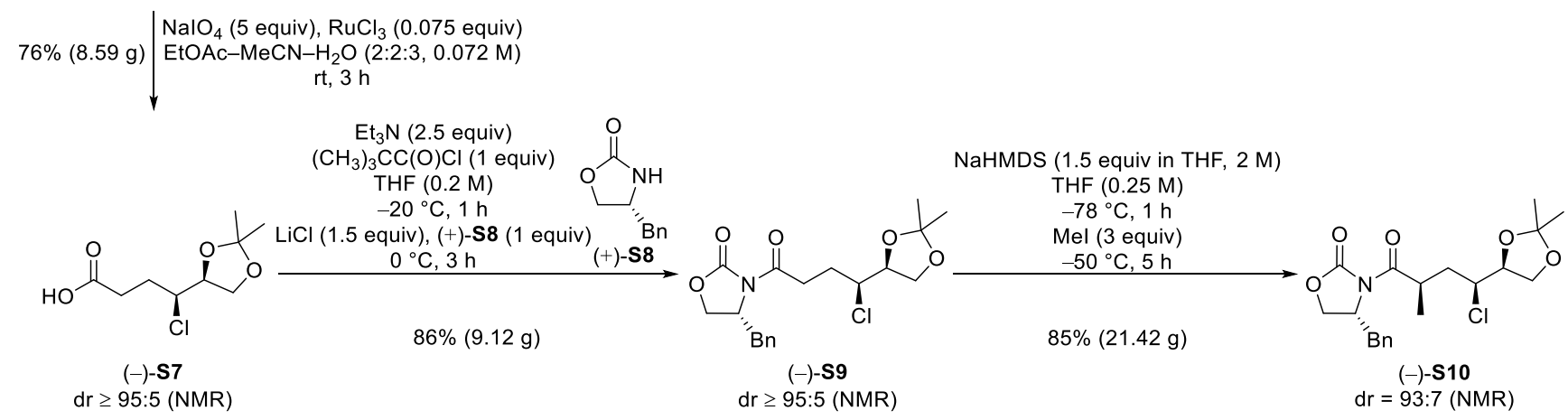

1. (-)-2 (1.1 equiv in $\mathrm{CH}_{2} \mathrm{Cl}_{2}, 0.23 \mathrm{M}$ ), $\mathrm{Et}_{3} \mathrm{~N}$ (2.8 equiv)

$(c \text {-hex })_{2}$ BOTf ( 2.5 equiv in $n$-hexane, $1 \mathrm{M}$ )

$-78{ }^{\circ} \mathrm{C}, 2 \mathrm{~h}$

(+)-3 (1 equiv in $\mathrm{CH}_{2} \mathrm{Cl}_{2}, 0.096 \mathrm{M}$ )

$-78^{\circ} \mathrm{C}, 2 \mathrm{~h} ;-70^{\circ} \mathrm{C}, 19 \mathrm{~h} ; 0^{\circ} \mathrm{C}, 1 \mathrm{~h}$

$(\rightarrow$ contaminated product)

2. $\mathrm{MOMCI}$, DIPEA, DMAP

$\mathrm{CH}_{2} \mathrm{Cl}_{2}$ $\mathrm{MesO}_{2} \mathrm{~S}^{-\mathrm{N}}$

$55{ }^{\circ} \mathrm{C}, 48 \mathrm{~h}$ ( $\rightarrow$ cont. product)

3. DIBAL-H (in $\mathrm{CH}_{2} \mathrm{Cl}_{2}, 1 \mathrm{M}$ )

$\mathrm{CH}_{2} \mathrm{Cl}_{2}$

$(-)-2$

$\mathrm{dr} \geq 95: 5$ (NMR)

$-78^{\circ} \mathrm{C}, 15 \mathrm{~min}$

$45 \%(4.34 \mathrm{~g})(-)-2$

$48 \%(4.08 \mathrm{~g}) \mathrm{S} 12$

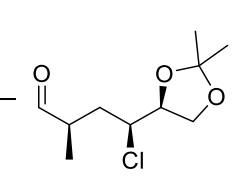

(+)-3

$\mathrm{dr}=93: 7(\mathrm{NMR})$

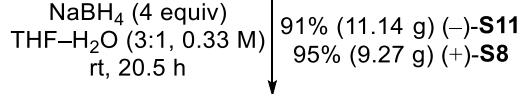

IBX ( 2.5 equiv $)$ $\mathrm{CH}_{2} \mathrm{Cl}_{2}$-DMSO $(1: 1,0.14 \mathrm{M})$

$0{ }^{\circ} \mathrm{C}, 10 \mathrm{~min} ; \mathrm{rt}, 4 \mathrm{~h}$

$92 \%(25.85 \mathrm{~g})$

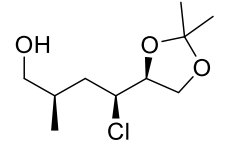

(-)-S11 $\mathrm{dr}=93: 7(\mathrm{NMR})$

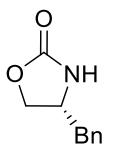

(+)-S8

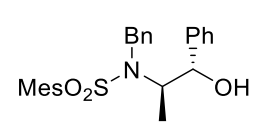

S12

$\mathrm{dr} \geq$ 95:5 (NMR)

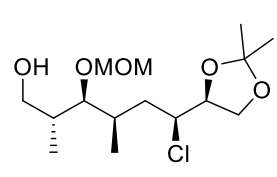

$(-)-4$

$\mathrm{dr}=82: 18(\mathrm{NMR})$
IBX (5 equiv)

$\mathrm{CH}_{2} \mathrm{Cl}_{2}$-DMSO $(1: 1,0.1 \mathrm{M})$ $0{ }^{\circ} \mathrm{C}, 5 \mathrm{~min} ; \mathrm{rt}, 5.5 \mathrm{~h}$

$93 \%(13.54 \mathrm{~g})$

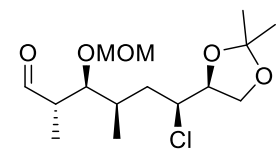

$(-)-5$

$\mathrm{dr}=82: 18(\mathrm{NMR})$

Stated masses refer to isolated masses after purification by chromatography.

Diastereoselectivities were determined from ${ }^{l} \mathrm{H}$ NMR spectra. 
Synthesis of a Diastereomer of the Marine Macrolide Lytophilippine A

\section{Synopsis (...continued...)}
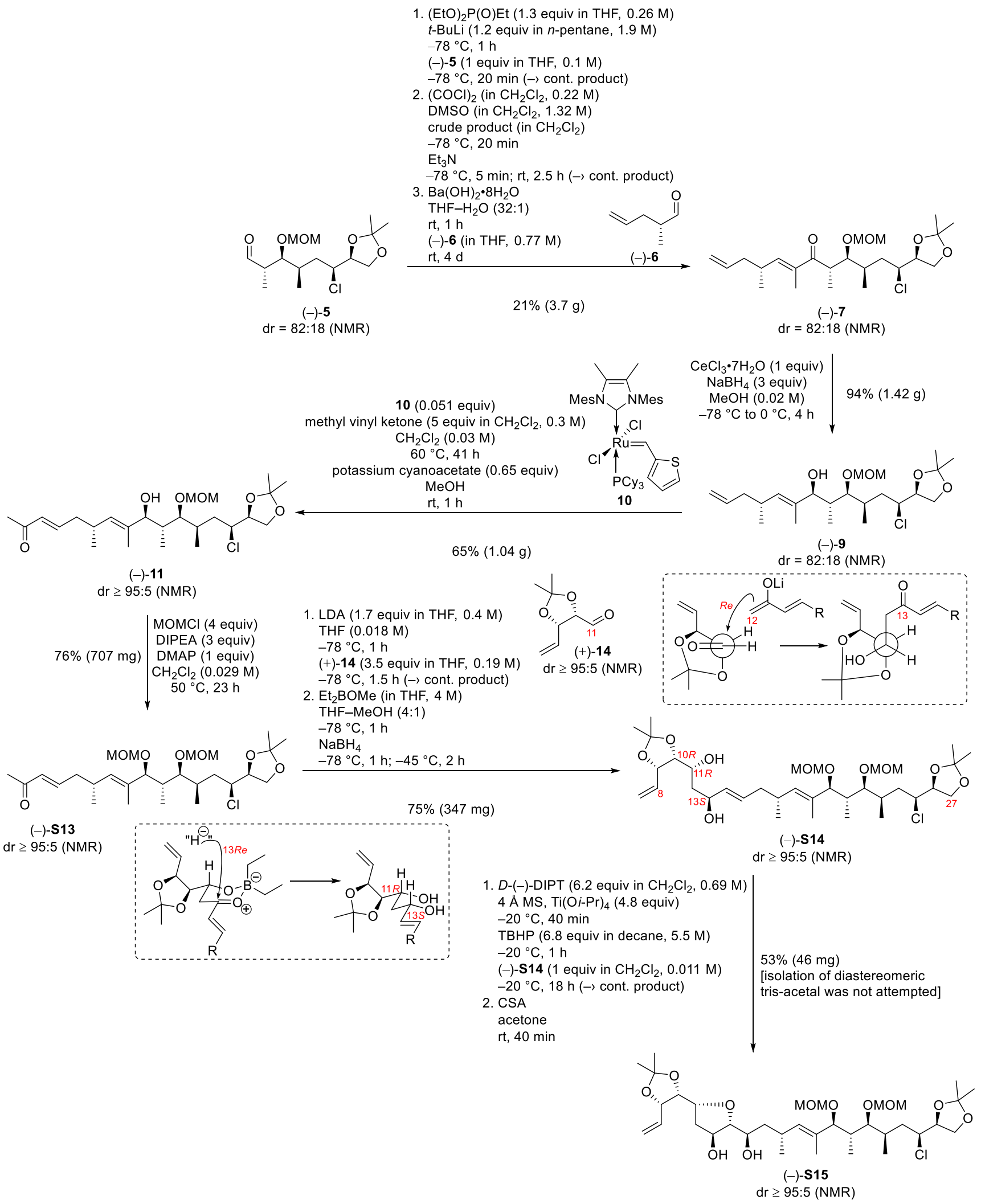

Stated masses refer to isolated masses after purification by chromatography.

Diastereoselectivities were determined from ${ }^{1} H$ NMR spectra. 


\section{Synopsis (...continued...)}
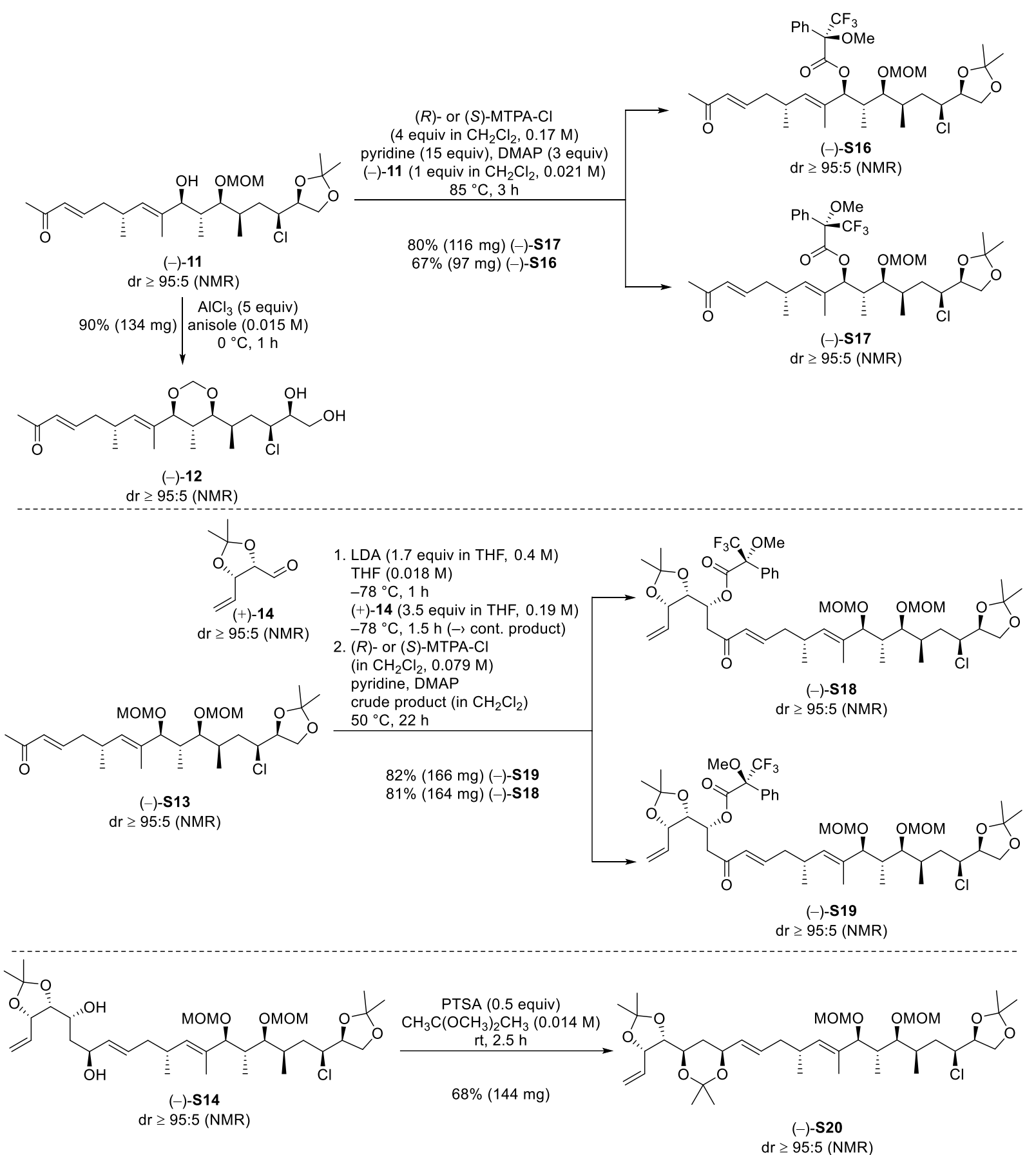

Stated masses refer to isolated masses after purification by chromatography.

Diastereoselectivities were determined from ${ }^{1} \mathrm{H}$ NMR spectra. 


\section{Synopsis (...continued...)}
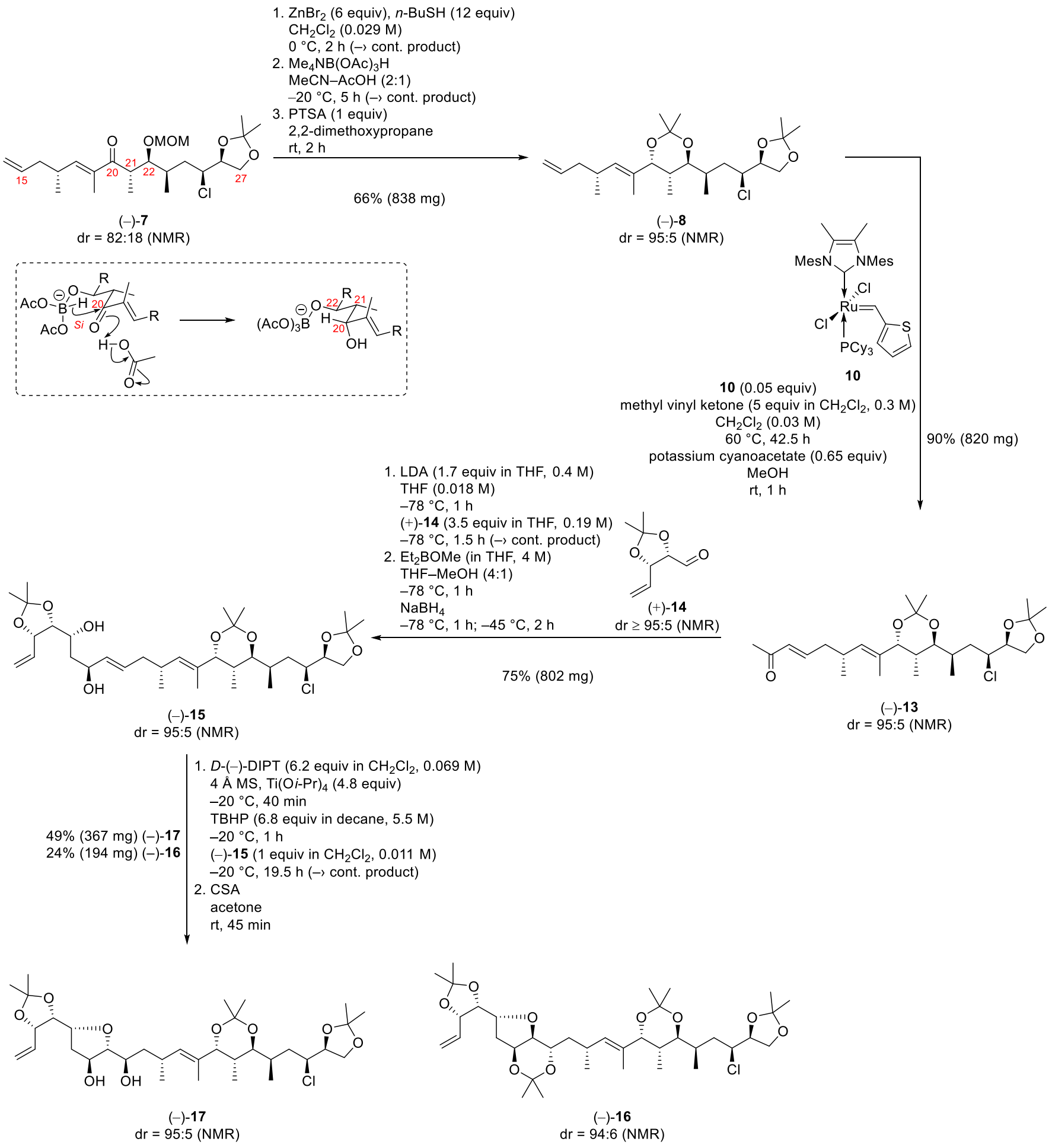

Stated masses refer to isolated masses after purification by chromatography. Diastereoselectivities were determined from ${ }^{l} \mathrm{H} N \mathrm{NR}$ spectra. 
Synthesis of a Diastereomer of the Marine Macrolide Lytophilippine A

\section{Synopsis (...continued)}

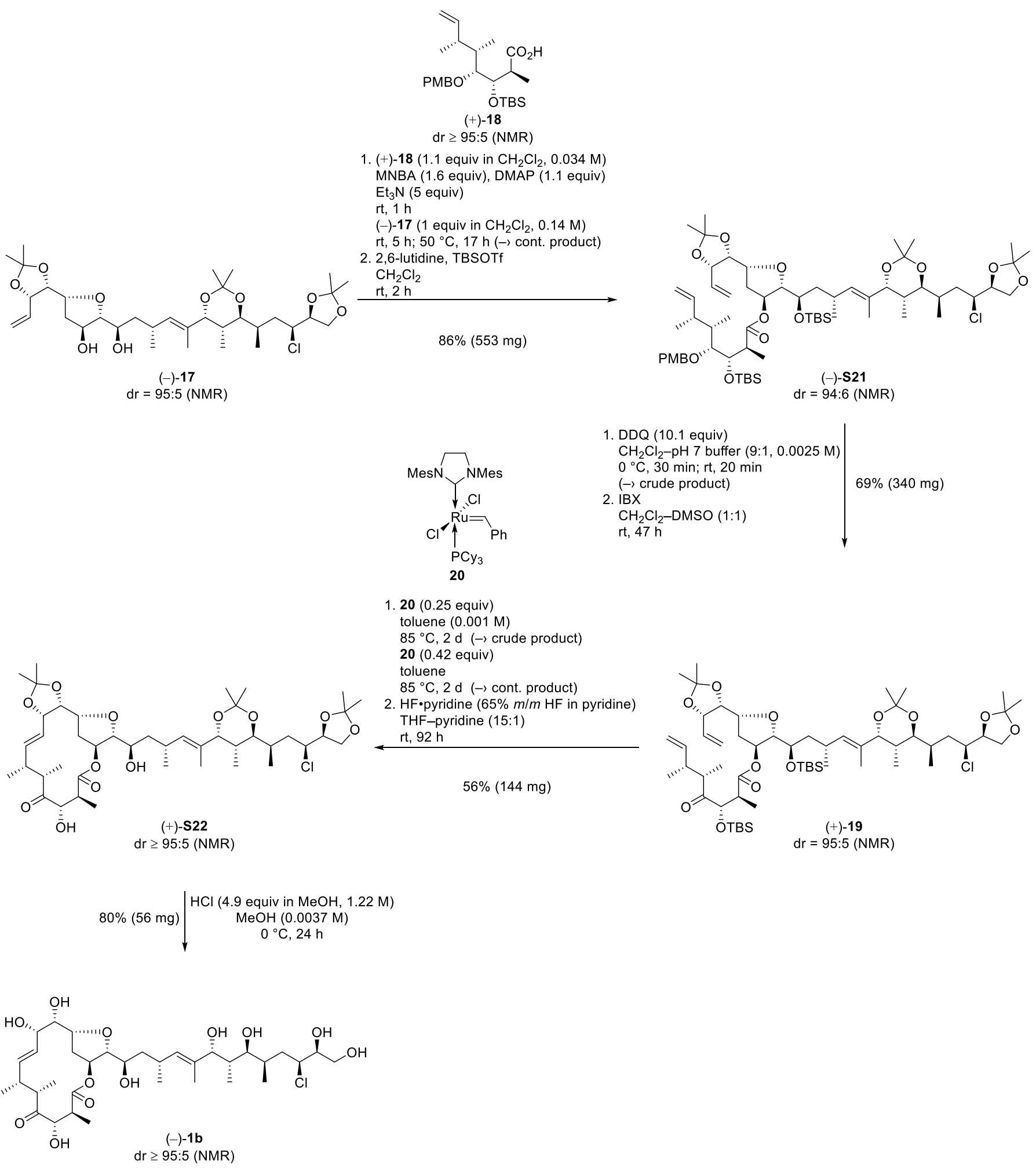

Stated masses refer to isolated masses after purification by chromatography.

Diastereoselectivities were determined from ${ }^{1} \mathrm{H} N \mathrm{NR}$ spectra. 


\section{Procedures and Characterization}

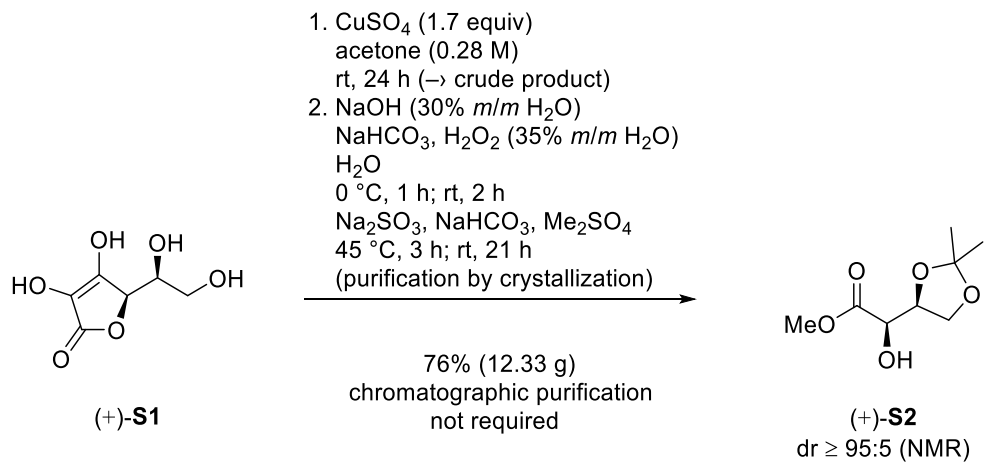

$\boldsymbol{\alpha}$-Hydroxy Ester (+)-S2. ${ }^{6}$ To a stirred suspension of $L$-(+)-ascorbic acid $\mathbf{S 1}\left(\mathrm{C}_{6} \mathrm{H}_{8} \mathrm{O}_{6}, 176.12 \mathrm{~g} / \mathrm{mol}, 15 \mathrm{~g}\right.$, $85.17 \mathrm{mmol}, 1$ equiv) in acetone $(300 \mathrm{~mL}, 0.28 \mathrm{M})$ was added anhydrous copper(II) sulfate $\left(\mathrm{CuSO}_{4}, 159.6\right.$ $\mathrm{g} / \mathrm{mol}, 23.11 \mathrm{~g}, 144.8 \mathrm{mmol}, 1.7$ equiv) in one portion. After being stirred for $24 \mathrm{~h}$ at ambient temperature, the grey suspension was filtered, and the solid grey residue was washed with acetone (4x). The filtrate was concentrated under reduced pressure to deliver a white solid (18.33 g), presumably the corresponding acetonide, which was used without proof of structure or of purity.

To a suspension of the white solid $(18.33 \mathrm{~g})$ in water $(85 \mathrm{~mL})$ was added $\mathrm{NaOH}(30 \% \mathrm{~m} / \mathrm{m}$ in water, 1.33 $\mathrm{g} / \mathrm{mL}, 7.66 \mathrm{~mL}, 10.19 \mathrm{~g}$ containing $3.06 \mathrm{~g} \mathrm{NaOH}, 39.997 \mathrm{~g} / \mathrm{mol}, 76.43 \mathrm{mmol}$ ). The suspension was stirred at ambient temperature until a homogenous yellowish solution was obtained. Sodium hydrogen carbonate $\left(\mathrm{NaHCO}_{3}, 84.01 \mathrm{~g} / \mathrm{mol}, 21.46 \mathrm{~g}, 255.45 \mathrm{mmol}\right)$ was subsequently added at ambient temperature. The resulting suspension was then cooled to $0{ }^{\circ} \mathrm{C}$ and hydrogen peroxide $\left(\mathrm{H}_{2} \mathrm{O}_{2}, 35 \% \mathrm{~m} / \mathrm{m}\right.$ in water, $16.55 \mathrm{~g}$ containing $5.79 \mathrm{~g} \mathrm{H}_{2} \mathrm{O}_{2}, 34.01 \mathrm{~g} / \mathrm{mol}, 170.32 \mathrm{mmol}$ ) was added dropwise over a period of $1 \mathrm{~h}$. The formation of a white foam was observed. After being stirred for $2 \mathrm{~h}$ at ambient temperature, sodium sulfite $\left(\mathrm{Na}_{2} \mathrm{SO}_{3}, 126.04 \mathrm{~g} / \mathrm{mol}, 1.4 \mathrm{~g}, 11.11 \mathrm{mmol}\right)$ and sodium hydrogen carbonate $\left(\mathrm{NaHCO}_{3}, 84.01 \mathrm{~g} / \mathrm{mol}\right.$, $14.31 \mathrm{~g}, 170.34 \mathrm{mmol})$ were added. The reaction flask was placed in a pre-heated oil bath $\left(45^{\circ} \mathrm{C}\right)$. Dimethyl sulfate $\left(\mathrm{Me}_{2} \mathrm{SO}_{4}, 126.13 \mathrm{~g} / \mathrm{mol}, 1.33 \mathrm{~g} / \mathrm{mL}, 32.3 \mathrm{~mL}, 42.96 \mathrm{~g}, 340.6 \mathrm{mmol}\right)$ was added dropwise over a period of $2 \mathrm{~h}$ at $45^{\circ} \mathrm{C}$, and stirring was continued for $1 \mathrm{~h}$ at $45^{\circ} \mathrm{C}$. The resulting white suspension was cooled to ambient temperature and stirring was continued for $21 \mathrm{~h}$. The reaction mixture was diluted by the addition of water and $\mathrm{CH}_{2} \mathrm{Cl}_{2}$ (1:2). The resulting biphasic mixture was transferred into a separatory funnel using $\mathrm{CH}_{2} \mathrm{Cl}_{2}$ for rinsing. The phases were separated, and the aqueous layer was extracted with $\mathrm{CH}_{2} \mathrm{Cl}_{2}(3 \times)$. The combined organic layers were dried $\left(\mathrm{MgSO}_{4}\right)$. Removal of the volatiles under reduced pressure afforded (+)-S2 $\left(\mathrm{C}_{8} \mathrm{H}_{14} \mathrm{O}_{5}, 190.2 \mathrm{~g} / \mathrm{mol}, 12.33 \mathrm{~g}, 64.82 \mathrm{mmol}, 76 \%\right.$, dr $\geq 95: 5$ according to NMR evaluation) as a slightly yellow oil and sufficiently pure for characterization. $\mathrm{R}_{\mathrm{f}} 0.34$ (cyclohexane-ethyl acetate, $1: 1) ;[\alpha]_{\mathrm{D}}{ }^{20}=+15.9\left(c=1, \mathrm{CHCl}_{3}\right) ;{ }^{1} \mathrm{H} \mathrm{NMR}\left(\mathrm{CDCl}_{3}, 500 \mathrm{MHz}\right) \delta 1.35(\mathrm{~s}$, $3 \mathrm{H}), 1.42(\mathrm{~s}, 3 \mathrm{H}), 2.92(\mathrm{~d}, J=8.1 \mathrm{~Hz}, 1 \mathrm{H}), 3.82(\mathrm{~s}, 3 \mathrm{H}), 4.01(\mathrm{dd}, J=8.3,6.8 \mathrm{~Hz}, 1 \mathrm{H}), 4.09(\mathrm{dd}, J=8.3$, $6.8 \mathrm{~Hz}, 1 \mathrm{H}), 4.12(\mathrm{dd}, J=8.1,2.8 \mathrm{~Hz}, 1 \mathrm{H}), 4.38$ (apparent td, $J=6.8,2.8 \mathrm{~Hz}, 1 \mathrm{H}) ;{ }^{13} \mathrm{C} \mathrm{NMR}\left(\mathrm{CDCl}_{3}, 126\right.$ MHz) $\delta 25.4\left(\mathrm{CH}_{3}\right), 26.2\left(\mathrm{CH}_{3}\right), 52.9\left(\mathrm{CH}_{3}\right), 65.7\left(\mathrm{CH}_{2}\right), 70.5(\mathrm{CH}), 76.4(\mathrm{CH}), 110.2(\mathrm{C}), 172.6(\mathrm{C})$; IR v 3470 (w), 2990 (w), 1745 (s), 1440 (m), 1375 (m), 1265 (m), 1215 (s), 1135 (s), 1070 (s), 1000 (w), 975 $(\mathrm{w}), 890(\mathrm{w}), 845(\mathrm{w}), 510(\mathrm{w}) \mathrm{cm}^{-1}$. Our analytical data matched those reported previously.

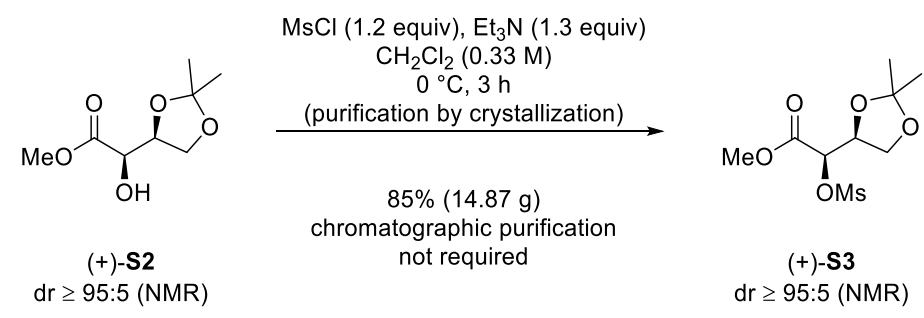

Mesylate (+)-S3. ${ }^{7}$ To a stirred solution of $\alpha$-hydroxy ester (+)-S2 $\left(\mathrm{C}_{8} \mathrm{H}_{14} \mathrm{O}_{5}, 190.2 \mathrm{~g} / \mathrm{mol}, 12.33 \mathrm{~g}, 64.83\right.$ mmol, 1 equiv) in $\mathrm{CH}_{2} \mathrm{Cl}_{2}(195 \mathrm{~mL}, 0.33 \mathrm{M})$ at $0{ }^{\circ} \mathrm{C}$ was added dropwise triethylamine $(\mathrm{Et} 3 \mathrm{~N}, 101.19$ 
$\mathrm{g} / \mathrm{mol}, 0.726 \mathrm{~g} / \mathrm{mL}, 11.82 \mathrm{~mL}, 8.58 \mathrm{~g}, 84.79 \mathrm{mmol}, 1.3$ equiv) and methanesulfonyl chloride (MsCl, $\mathrm{CH}_{3} \mathrm{ClO}_{2} \mathrm{~S}, 114.54 \mathrm{~g} / \mathrm{mol}, 1.48 \mathrm{~g} / \mathrm{mL}, 6.02 \mathrm{~mL}, 8.91 \mathrm{~g}, 77.79 \mathrm{mmol}, 1.2$ equiv) yielding a cloudy yellow suspension. After being stirred for $3 \mathrm{~h}$ at $0{ }^{\circ} \mathrm{C}$, the reaction mixture was diluted by the addition of saturated aqueous $\mathrm{NH}_{4} \mathrm{Cl}$ solution. The resulting biphasic mixture was transferred into a separatory funnel using $\mathrm{CH}_{2} \mathrm{Cl}_{2}$ for rinsing. The phases were separated, and the aqueous layer was extracted with $\mathrm{CH}_{2} \mathrm{Cl}_{2}$ (3x). The combined organic layers were dried $\left(\mathrm{MgSO}_{4}\right)$. Removal of the volatiles under reduced pressure afforded a slightly yellow solid, which was dissolved in a small amount of ethyl acetate $(50 \mathrm{~mL})$. Subsequent dilution with cyclohexane $(700 \mathrm{~mL})$ triggered precipitation of a yellowish solid. The solid was collected by filtration and successively washed with cyclohexane $(4 \times)$ and cold ethanol $(2 \times)$. Removal of all volatiles under reduced pressure afforded (+)-S3 $\left(\mathrm{C}_{9} \mathrm{H}_{16} \mathrm{O}_{7} \mathrm{~S}, 268.28 \mathrm{~g} / \mathrm{mol}, 14.87 \mathrm{~g}, 55.43 \mathrm{mmol}, 85 \%\right.$, $\mathrm{dr} \geq 95: 5$ according to NMR evaluation) as a white solid sufficiently pure for characterization. $\mathrm{R}_{\mathrm{f}} 0.37$ (cyclohexane-ethyl acetate, 1:1); m.p. $113.8{ }^{\circ} \mathrm{C} ;[\alpha]_{\mathrm{D}}{ }^{20}=+34.4\left(c=1, \mathrm{CHCl}_{3}\right) ;{ }^{1} \mathrm{H} \mathrm{NMR}\left(\mathrm{CDCl}_{3}, 500\right.$ $\mathrm{MHz}) \delta 1.35(\mathrm{~s}, 3 \mathrm{H}), 1.44(\mathrm{~s}, 3 \mathrm{H}), 3.19(\mathrm{~s}, 3 \mathrm{H}), 3.84(\mathrm{~s}, 3 \mathrm{H}), 4.03(\mathrm{dd}, J=8.9,5.5 \mathrm{~Hz}, 1 \mathrm{H}), 4.14(\mathrm{dd}, J=$ 8.9, $6.7 \mathrm{~Hz}, 1 \mathrm{H}), 4.54$ (apparent dt, $J=6.6,5.3 \mathrm{~Hz}, 1 \mathrm{H}), 5.00(\mathrm{~d}, J=4.9 \mathrm{~Hz}, 1 \mathrm{H}) ;{ }^{13} \mathrm{C} \mathrm{NMR}\left(\mathrm{CDCl}_{3}, 126\right.$ $\mathrm{MHz}) \delta 25.4\left(\mathrm{CH}_{3}\right), 26.2\left(\mathrm{CH}_{3}\right), 39.3\left(\mathrm{CH}_{3}\right) 53.2\left(\mathrm{CH}_{3}\right), 65.6\left(\mathrm{CH}_{2}\right), 74.7(\mathrm{CH}), 77.4(\mathrm{CH}), 110.8(\mathrm{C})$, $167.3(\mathrm{C}) ; \mathrm{IR} \vee 2990(\mathrm{~m}), 1755$ (s), 1440 (m), 1370 (s), 1335 (s),1275 (m), 1220 (s), 1175 (s), 1110 (m), $1060(\mathrm{~m}), 990(\mathrm{~m}), 970(\mathrm{~m}), 865(\mathrm{~m}), 785(\mathrm{~m}), 540(\mathrm{~s}), 515(\mathrm{~s}) \mathrm{cm}^{-1}$. Our analytical data matched those reported previously.

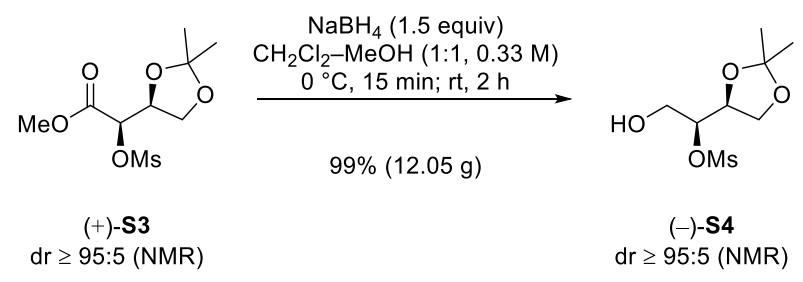

Alcohol (-)-S4. To a stirred solution of mesylate (+)-S3 $\left(\mathrm{C}_{9} \mathrm{H}_{16} \mathrm{O}_{7} \mathrm{~S}, 268.28 \mathrm{~g} / \mathrm{mol}, 26.49 \mathrm{~g}, 98.74 \mathrm{mmol}\right.$, 1 equiv) in $\mathrm{CH}_{2} \mathrm{Cl}_{2}(150 \mathrm{~mL})$ and methanol $(150 \mathrm{~mL})$ (overall: $\left.0.33 \mathrm{M}\right)$ at $0{ }^{\circ} \mathrm{C}$ was added sodium borohydride $\left(\mathrm{NaBH}_{4}, 37.83 \mathrm{~g} / \mathrm{mol}, 5.6 \mathrm{~g}, 148.03 \mathrm{mmol}, 1.5\right.$ equiv) in three portions over a period of 5 min. Gas formation was observed and stirring was continued for $15 \mathrm{~min}$ at $0{ }^{\circ} \mathrm{C}$. After being stirred for $2 \mathrm{~h}$ at ambient temperature, the slightly yellow reaction mixture was diluted by the addition of saturated aqueous $\mathrm{NH}_{4} \mathrm{Cl}$ solution. The resulting biphasic mixture was transferred into a separatory funnel using $\mathrm{CH}_{2} \mathrm{Cl}_{2}$ for rinsing. The phases were separated, and the aqueous layer was extracted with ethyl acetate $(3 \times)$. The combined organic layers were dried $\left(\mathrm{MgSO}_{4}\right)$. Removal of all volatiles under reduced pressure and subsequent purification of the slightly yellow oil by flash chromatography (cyclohexane-ethyl acetate, 5:1 to 1:1) delivered (-)-S4 $\left(\mathrm{C}_{8} \mathrm{H}_{16} \mathrm{O}_{6} \mathrm{~S}, 240.27 \mathrm{~g} / \mathrm{mol}, 23.47 \mathrm{~g}, 97.68 \mathrm{mmol}, 99 \%\right.$, dr $\geq 95: 5$ according to NMR evaluation) as a colorless oil. $\mathrm{R}_{\mathrm{f}} 0.17$ (cyclohexane-ethyl acetate, $\left.1: 1\right) ;[\alpha]_{\mathrm{D}}{ }^{20}=-3.4(c$ $\left.=1, \mathrm{CHCl}_{3}\right) ;{ }^{1} \mathrm{H} \mathrm{NMR}\left(\mathrm{CDCl}_{3}, 500 \mathrm{MHz}\right) \delta 1.35(\mathrm{~s}, 3 \mathrm{H}), 1.44(\mathrm{~s}, 3 \mathrm{H}), 2.44(\mathrm{t}, J=5.8 \mathrm{~Hz}, 1 \mathrm{H}), 3.14(\mathrm{~s}$, $3 \mathrm{H}), 3.78-3.88(\mathrm{~m}, 2 \mathrm{H}), 3.90(\mathrm{dd}, J=8.9,6.2 \mathrm{~Hz}, 1 \mathrm{H}), 4.10(\mathrm{dd}, J=8.7,6.7 \mathrm{~Hz}, 1 \mathrm{H}), 4.35$ (apparent q, $J$ $=6.0 \mathrm{~Hz}, 1 \mathrm{H}), 4.67$ (apparent td, $J=5.7,3.7 \mathrm{~Hz}, 1 \mathrm{H}) ;{ }^{13} \mathrm{C} \mathrm{NMR}\left(\mathrm{CDCl}_{3}, 126 \mathrm{MHz}\right) \delta 25.3\left(\mathrm{CH}_{3}\right), 26.3$ $\left(\mathrm{CH}_{3}\right), 38.8\left(\mathrm{CH}_{3}\right), 62.5\left(\mathrm{CH}_{2}\right), 65.6\left(\mathrm{CH}_{2}\right), 74.8(\mathrm{CH}), 82.9(\mathrm{CH}), 110.2(\mathrm{C}) ; \mathrm{IR} \vee 3475(\mathrm{~m}), 2990(\mathrm{~m})$, 2940 (m), 2895 (m), 1460 (m), 1355 (s), 1260 (s), 1215 (s), 1175 (s), 1120 (m), 1075 (s), 970 (s), 925 (s), 850 (s), 815 (m), 525 (m) cm ${ }^{-1}$; Anal. Calcd. for $\mathrm{C}_{8} \mathrm{H}_{16} \mathrm{O}_{6} \mathrm{~S}: \mathrm{C}, 40.0$; H, 6.7; Found: C, 39.9; H, 6.6.

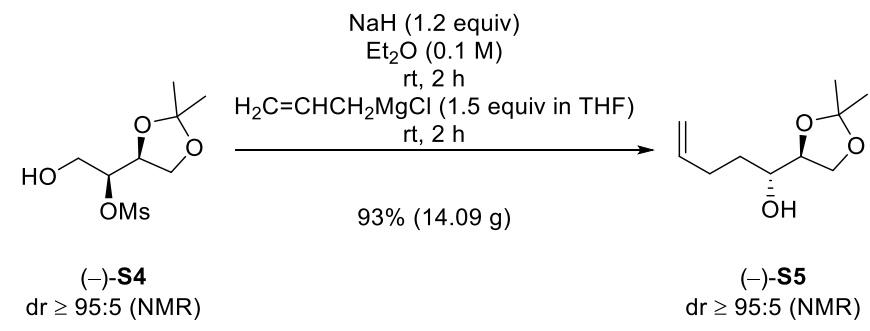

Bis(homoallylic) Alcohol (-)-S5. ${ }^{8}$ Note: This telescoped one-pot procedure merges epoxide formation 
and epoxide opening. To a stirred solution of the alcohol (-)-S4 $\left(\mathrm{C}_{8} \mathrm{H}_{16} \mathrm{O}_{6} \mathrm{~S}, 240.27 \mathrm{~g} / \mathrm{mol}, 19.56 \mathrm{~g}, 81.4\right.$ mmol, 1 equiv) in diethyl ether $(814 \mathrm{~mL}, 0.1 \mathrm{M})$ at $0{ }^{\circ} \mathrm{C}$ was added sodium hydride $(\mathrm{NaH}, 60 \% \mathrm{~m} / \mathrm{m}$ dispersion in mineral oil, $3.9 \mathrm{~g}$ containing $2.34 \mathrm{~g} \mathrm{NaH}, 24 \mathrm{~g} / \mathrm{mol}, 97.5 \mathrm{mmol}, 1.2$ equiv) to afford an orange suspension. After being stirred for $2 \mathrm{~h}$ at ambient temperature, the orange suspension was cooled to $0{ }^{\circ} \mathrm{C}$ and allylmagnesium chloride $\left(\mathrm{C}_{3} \mathrm{H}_{5} \mathrm{ClMg}, 1.7 \mathrm{M}\right.$ in THF, $71.8 \mathrm{~mL}, 122.06 \mathrm{mmol}, 1.5$ equiv) was added. After being stirred for $2 \mathrm{~h}$ at ambient temperature, the grayish orange suspension was diluted by the addition of saturated aqueous $\mathrm{NH}_{4} \mathrm{Cl}$ solution. The resulting biphasic mixture was transferred into a separatory funnel using diethyl ether for rinsing. The phases were separated, and the aqueous layer was extracted with diethyl ether $(3 \times)$. The combined organic layers were dried $\left(\mathrm{MgSO}_{4}\right)$. Removal of all volatiles under reduced pressure and subsequent purification of the yellow oil by flash chromatography (n-pentane-diethyl ether, 50:1 to 2:1) delivered volatile (-)-S5 $\left(\mathrm{C}_{10} \mathrm{H}_{18} \mathrm{O}_{3}, 186.25 \mathrm{~g} / \mathrm{mol}, 14.09 \mathrm{~g}, 75.65\right.$ mmol, 93\%, dr $\geq 95: 5$ according to NMR evaluation) as a colorless oil. $\mathrm{R}_{\mathrm{f}} 0.29$ (cyclohexane-ethyl acetate, 2:1); $[\alpha]_{\mathrm{D}}{ }^{20}=-18.4\left(c=1, \mathrm{CHCl}_{3}\right) ;{ }^{1} \mathrm{H} \mathrm{NMR}\left(\mathrm{CDCl}_{3}, 500 \mathrm{MHz}\right) \delta 1.36(\mathrm{~s}, 3 \mathrm{H}), 1.42(\mathrm{~s}, 3 \mathrm{H})$, $1.43-1.50(\mathrm{~m}, 1 \mathrm{H}), 1.52-1.61(\mathrm{~m}, 1 \mathrm{H}), 2.02$ (br. s, $1 \mathrm{H}), 2.10-2.21(\mathrm{~m}, 1 \mathrm{H}), 2.23-2.33(\mathrm{~m}, 1 \mathrm{H}), 3.78$ (apparent dt, $J=8.0,3.4 \mathrm{~Hz}, 1 \mathrm{H}$ ), 3.90 (apparent t, $J=7.3 \mathrm{~Hz}, 1 \mathrm{H}), 3.97$ (apparent t, $J=7.3 \mathrm{~Hz}, 1 \mathrm{H}$ ), 4.02 (apparent td, $J=7.0,4.2 \mathrm{~Hz}, 1 \mathrm{H}), 4.98(\mathrm{dd}, J=10.1,1.0 \mathrm{~Hz}, 1 \mathrm{H}), 5.06(\mathrm{dd}, J=17.2,1.5 \mathrm{~Hz}, 1 \mathrm{H}), 5.82$ (apparent ddt, $J=17.1,10.3,6.6 \mathrm{~Hz}, 1 \mathrm{H}) ;{ }^{13} \mathrm{C} \mathrm{NMR}\left(\mathrm{CDCl}_{3}, 126 \mathrm{MHz}\right) \delta 25.4\left(\mathrm{CH}_{3}\right), 26.6\left(\mathrm{CH}_{3}\right), 30.1$ $\left(\mathrm{CH}_{2}\right), 32.0\left(\mathrm{CH}_{2}\right), 64.8\left(\mathrm{CH}_{2}\right), 70.5(\mathrm{CH}), 78.8(\mathrm{CH}), 109.1(\mathrm{C}), 115.3\left(\mathrm{CH}_{2}\right), 138.2(\mathrm{CH}) ; \mathrm{IR} v 3460(\mathrm{~s})$, 3075 (w), 2985 (s), 2935 (s), 1640 (m), 1455 (m), 1415 (w), 1370 (s), 1255 (s), 1215 (s), 1160 (s), 1070 (s), $995(\mathrm{~m}), 915(\mathrm{~s}), 855(\mathrm{~s}), 515(\mathrm{w}) \mathrm{cm}^{-1}$. Our analytical data matched those reported in the literature.
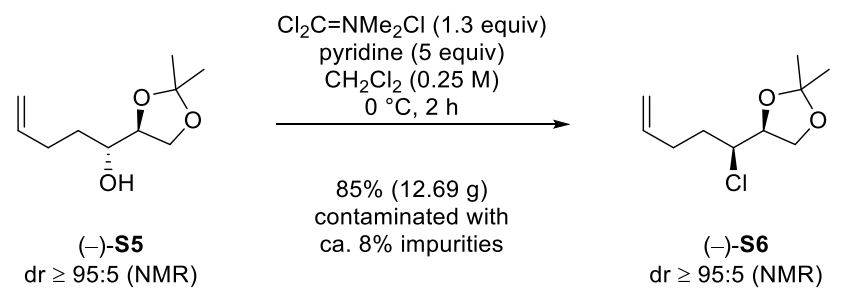

Chloride (-)-S6. ${ }^{8}$ To a stirred solution of bis(homoallylic) alcohol (-)-S5 $\left(\mathrm{C}_{10} \mathrm{H}_{18} \mathrm{O}_{3}, 186.25 \mathrm{~g} / \mathrm{mol}, 13.55\right.$ $\mathrm{g}, 72.75 \mathrm{mmol}, 1$ equiv) in $\mathrm{CH}_{2} \mathrm{Cl}_{2}(291 \mathrm{~mL}, 0.25 \mathrm{M})$ at $0{ }^{\circ} \mathrm{C}$ was added pyridine $\left(\mathrm{C}_{5} \mathrm{H}_{5} \mathrm{~N}, 79.1 \mathrm{~g} / \mathrm{mol}\right.$, $0.98 \mathrm{~g} / \mathrm{mL}, 29.36 \mathrm{~mL}, 28.77 \mathrm{~g}, 363.72 \mathrm{mmol}, 5$ equiv $)$ and phosgene iminium chloride $\left(\mathrm{C}_{3} \mathrm{H}_{6} \mathrm{Cl}_{3} \mathrm{~N}, 162.44\right.$ $\mathrm{g} / \mathrm{mol}, 15.36 \mathrm{~g}, 94.56 \mathrm{mmol}, 1.3$ equiv). After being stirred for $45 \mathrm{~min}$ at $0{ }^{\circ} \mathrm{C}$, the yellow reaction mixture was diluted by the addition of methanol $(364 \mathrm{~mL})$ and stirring was continued for $30 \mathrm{~min}$ at $0{ }^{\circ} \mathrm{C}$. The reaction mixture was diluted by the addition of aqueous $1 \mathrm{M} \mathrm{NaOH}$ solution and stirring was continued for $1 \mathrm{~h}$ at ambient temperature. The resulting biphasic mixture was transferred into a separatory funnel using $\mathrm{CH}_{2} \mathrm{Cl}_{2}$ for rinsing. The phases were separated, and the aqueous layer was extracted with diethyl ether $(3 \times)$. The combined organic layers were dried $\left(\mathrm{MgSO}_{4}\right)$. Removal of all volatiles under reduced pressure and subsequent purification of the yellow oil by flash chromatography ( $n$-pentane-diethyl ether, 500:1 to 50:1) delivered volatile (-)-S6 $\left(\mathrm{C}_{10} \mathrm{H}_{17} \mathrm{ClO}_{2}, 204.69 \mathrm{~g} / \mathrm{mol}, 12.69 \mathrm{~g}, 62 \mathrm{mmol}, 85 \%\right.$, dr $\geq 95: 5$ according to NMR evaluation) as a slightly yellow oil contaminated with NMR-visible but inseparable impurities (ca. 8\% n/n). $\mathrm{R}_{\mathrm{f}} 0.49$ (cyclohexane-ethyl acetate, $\left.5: 1\right) ;[\alpha]_{\mathrm{D}}{ }^{20}=-31.0\left(c=1, \mathrm{CHCl}_{3}\right) ;{ }^{1} \mathrm{H}$ NMR $\left(\mathrm{CDCl}_{3}, 400 \mathrm{MHz}\right) \delta 1.36(\mathrm{~s}, 3 \mathrm{H}), 1.46(\mathrm{~s}, 3 \mathrm{H}), 1.71-1.90(\mathrm{~m}, 2 \mathrm{H}), 2.14-2.26(\mathrm{~m}, 1 \mathrm{H}), 2.31-2.43(\mathrm{~m}, 1 \mathrm{H})$, $3.87(\mathrm{dd}, J=8.6,6.3 \mathrm{~Hz}, 1 \mathrm{H}), 3.87-3.93(\mathrm{~m}, 1 \mathrm{H}), 4.06(\mathrm{dd}, J=8.6,6.7 \mathrm{~Hz}, 1 \mathrm{H}), 4.28$ (apparent td, $J=$ 6.4, 5.2 Hz, 1H), 4.99-5.04 (m, 1H), 5.08 (apparent dq, $J=17.1,1.6 \mathrm{~Hz}, 1 \mathrm{H}), 5.77$ (dddd, $J=17.1,10.3$, 7.2, $6.0 \mathrm{~Hz}, 1 \mathrm{H}) ;{ }^{13} \mathrm{C} \mathrm{NMR}\left(\mathrm{CDCl}_{3}, 101 \mathrm{MHz}\right) \delta 25.3\left(\mathrm{CH}_{3}\right), 26.3\left(\mathrm{CH}_{3}\right), 30.5\left(\mathrm{CH}_{2}\right), 32.5\left(\mathrm{CH}_{2}\right), 61.8$ $(\mathrm{CH}), 66.4\left(\mathrm{CH}_{2}\right), 78.4(\mathrm{CH}), 110.1(\mathrm{C}), 116.1\left(\mathrm{CH}_{2}\right), 137.0(\mathrm{CH})$; IR v $3080(\mathrm{w}), 2985(\mathrm{~s}), 2935(\mathrm{~s}), 2890$ (m), 1640 (m), 1455 (m), 1380 (s), 1370 (s), 1265 (s), 1215 (s), 1155 (s), 1065 (s), 1000 (m), 915 (s), 855 (s) $\mathrm{cm}^{-1}$. Our analytical data matched those reported in the literature. 


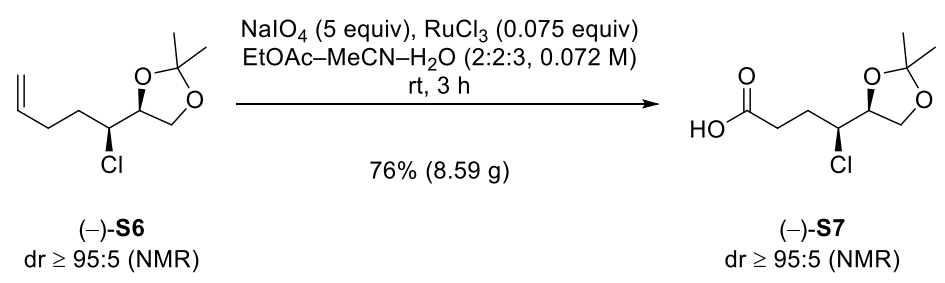

Carboxylic Acid (-)-S7. ${ }^{8}$ Note: This procedure was optimized to replace $\mathrm{CCl}_{4}$ in the solvent system by EtOAc. To a stirred solution of the chloride (-)-S6 $\left(\mathrm{C}_{10} \mathrm{H}_{17} \mathrm{ClO}_{2}, 204.69 \mathrm{~g} / \mathrm{mol}, 10.36 \mathrm{~g}, 50.61 \mathrm{mmol}, 1\right.$ equiv) in ethyl acetate $(202 \mathrm{~mL})$, acetonitrile $(202 \mathrm{~mL})$ and water $(303 \mathrm{~mL})$ (overall: $0.072 \mathrm{M})$ was added sodium periodate $\left(\mathrm{NaIO}_{4}, 213.89 \mathrm{~g} / \mathrm{mol}, 54.1 \mathrm{~g}, 252.93 \mathrm{mmol}, 5\right.$ equiv) to afford a colorless emulsion. After $10 \mathrm{~min}$ at ambient temperature, anhydrous ruthenium(III) chloride $\left(\mathrm{RuCl}_{3}, 207.42 \mathrm{~g} / \mathrm{mol}, 0.79 \mathrm{~g}\right.$, $3.81 \mathrm{mmol}, 0.075$ equiv) was added. Vigorous stirring of the biphasic black mixture was continued at room temperature for $3 \mathrm{~h}$ at which point a white solid had precipitated. The reaction mixture was diluted by the addition of saturated aqueous $\mathrm{NH}_{4} \mathrm{Cl}$ solution and water $(v / v=1: 1)$. The resulting purple biphasic mixture was transferred into a separatory funnel using ethyl acetate for rinsing. The phases were separated, and the aqueous layer was extracted with ethyl acetate $(4 \times)$. The combined organic layers were dried $\left(\mathrm{MgSO}_{4}\right)$. Removal of all volatiles under reduced pressure and subsequent purification of the black oil by flash chromatography (cyclohexane-ethyl acetate, $20: 1$ to $2: 1)$ delivered (-)-S7 $\left(\mathrm{C}_{9} \mathrm{H}_{15} \mathrm{ClO}_{4}, 222.67\right.$ $\mathrm{g} / \mathrm{mol}, 8.59 \mathrm{~g}, 38.58 \mathrm{mmol}, 76 \%$, dr $\geq 95: 5$ according to NMR evaluation) as a colorless amorphous solid. $\mathrm{R}_{\mathrm{f}} 0.51$ (cyclohexane-ethyl acetate, 1:2); m.p. $38.1^{\circ} \mathrm{C} ;[\alpha]_{\mathrm{D}}{ }^{20}=-27.5\left(c=1, \mathrm{CHCl}_{3}\right) ;{ }^{1} \mathrm{H} \mathrm{NMR}\left(\mathrm{CDCl}_{3}\right.$, $400 \mathrm{MHz}) \delta 1.37(\mathrm{~s}, 3 \mathrm{H}), 1.46(\mathrm{~s}, 3 \mathrm{H}), 1.97$ (dddd, $J=14.5,10.9,7.8,5.5 \mathrm{~Hz}, 1 \mathrm{H}), 2.16$ (apparent dtd, $J=$ 14.8, 7.5, 2.7 Hz, 1H), 2.53-2.75 (m, 2H), 3.91 (dd, $J=8.7,6.2 \mathrm{~Hz}, 1 \mathrm{H}), 3.99$ (ddd, $J=10.8,4.8,3.0 \mathrm{~Hz}$, $1 \mathrm{H}), 4.09$ (dd, $J=8.5,6.8 \mathrm{~Hz}, 1 \mathrm{H}), 4.29$ (apparent $\mathrm{td}, J=6.3,4.8 \mathrm{~Hz}, 1 \mathrm{H})$, note: $\mathrm{CO}_{2} \mathrm{H}$ signal was not detectable; ${ }^{13} \mathrm{C}$ NMR $\left(\mathrm{CDCl}_{3}, 101 \mathrm{MHz}\right) \delta 25.2\left(\mathrm{CH}_{3}\right), 26.3\left(\mathrm{CH}_{3}\right), 28.5\left(\mathrm{CH}_{2}\right), 30.8\left(\mathrm{CH}_{2}\right), 61.3(\mathrm{CH})$, $66.3\left(\mathrm{CH}_{2}\right), 78.2(\mathrm{CH}), 110.4(\mathrm{C}), 178.9(\mathrm{C})$; IR $\vee 2985(\mathrm{w}), 1710(\mathrm{~s}), 1445(\mathrm{~m}), 1370(\mathrm{~m}), 1260(\mathrm{~m})$, $1210(\mathrm{~m}), 1160(\mathrm{~m}), 1070(\mathrm{~s}), 915(\mathrm{~m}), 845(\mathrm{~s}), 800(\mathrm{~m}), 685(\mathrm{~m}) \mathrm{cm}^{-1}$. Our analytical data matched those reported in the literature.

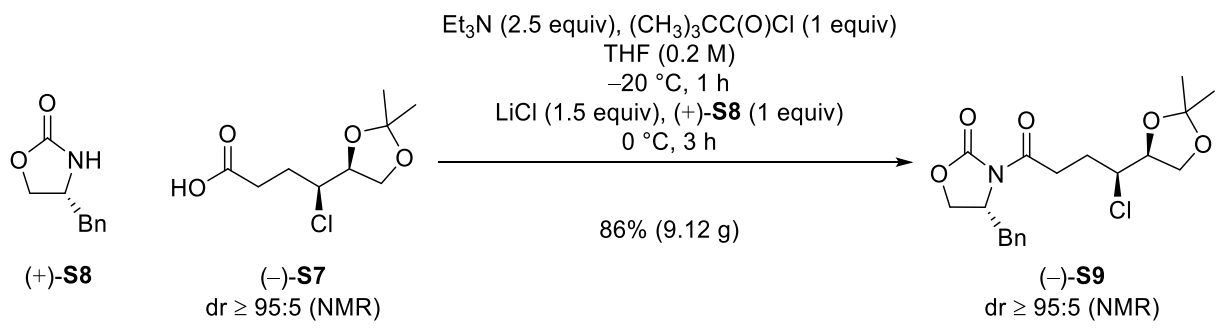

Imide (-)-S9. ${ }^{8,9}$ To a stirred solution of the carboxylic acid (-)-S7 $\left(\mathrm{C}_{9} \mathrm{H}_{15} \mathrm{ClO}_{4}, 222.67 \mathrm{~g} / \mathrm{mol}, 6.18 \mathrm{~g}\right.$, $27.75 \mathrm{mmol}, 1$ equiv) in THF $(140 \mathrm{~mL}, 0.2 \mathrm{M})$ at $-20{ }^{\circ} \mathrm{C}$ was added triethylamine $\left(\mathrm{Et}_{3} \mathrm{~N}, 101.19 \mathrm{~g} / \mathrm{mol}\right.$, $0.726 \mathrm{~g} / \mathrm{mL}, 9.72 \mathrm{~mL}, 7.06 \mathrm{~g}, 69.77 \mathrm{mmol}, 2.5$ equiv) and pivaloyl chloride $\left(\mathrm{C}_{5} \mathrm{H}_{9} \mathrm{ClO}, 120.58 \mathrm{~g} / \mathrm{mol}, 0.98\right.$ $\mathrm{g} / \mathrm{mL}, 3.41 \mathrm{~mL}, 3.34 \mathrm{~g}, 27.7 \mathrm{mmol}, 1$ equiv) to afford a white suspension. After being stirred for $1 \mathrm{~h}$ at $20{ }^{\circ} \mathrm{C}$, the white suspension was warmed to $0{ }^{\circ} \mathrm{C}$. Dried $\left(0.05 \mathrm{mbar}, 175{ }^{\circ} \mathrm{C}, 1 \mathrm{~h}\right)$ lithium choride $(\mathrm{LiCl}$, $42.39 \mathrm{~g} / \mathrm{mol}, 1.76 \mathrm{~g}, 41.52 \mathrm{mmol}, 1.5 \mathrm{equiv})$ and (+)-S8 ${ }^{10}\left(\mathrm{C}_{10} \mathrm{H}_{11} \mathrm{NO}_{2}, 177.2 \mathrm{~g} / \mathrm{mol}, 4.92 \mathrm{~g}, 27.77 \mathrm{mmol}\right.$, 1 equiv) were added to afford a white suspension. After being stirred for $3 \mathrm{~h}$ at $0{ }^{\circ} \mathrm{C}$, the white suspension was diluted by the addition of saturated aqueous $\mathrm{NH}_{4} \mathrm{Cl}$ solution. The resulting biphasic mixture was transferred into a separatory funnel using diethyl ether for rinsing. The phases were separated, and the aqueous layer was extracted with diethyl ether $(3 \times)$. The combined organic layers were dried $\left(\mathrm{MgSO}_{4}\right)$. Removal of all volatiles under reduced pressure and subsequent purification of the yellow oil by flash chromatography (cyclohexane-ethyl acetate, 5:1 to 1:1) delivered (-)-S9 $\left(\mathrm{C}_{19} \mathrm{H}_{24} \mathrm{ClNO}_{5}, 381.85 \mathrm{~g} / \mathrm{mol}\right.$, $9.12 \mathrm{~g}, 23.88 \mathrm{mmol}, 86 \%$, dr $\geq 95: 5$ according to NMR evaluation) as a white solid. $\mathrm{R}_{\mathrm{f}} 0.31$ (cyclohexane-ethyl acetate, 2:1); m.p. $59.2{ }^{\circ} \mathrm{C}$; $[\alpha]_{\mathrm{D}}{ }^{20}=-57.5\left(c=1, \mathrm{CHCl}_{3}\right) ;{ }^{1} \mathrm{H} \mathrm{NMR}\left(\mathrm{CDCl}_{3}, 300\right.$ $\mathrm{MHz}) \delta 1.38(\mathrm{~s}, 3 \mathrm{H}), 1.48(\mathrm{~s}, 3 \mathrm{H}), 2.02$ (dddd, $J=14.6,10.7,6.9,5.9 \mathrm{~Hz}, 1 \mathrm{H}), 2.25$ (apparent dtd, $J=$ 14.8, 7.5, $2.7 \mathrm{~Hz}, 1 \mathrm{H}), 2.76(\mathrm{dd}, J=13.4,9.7 \mathrm{~Hz}, 1 \mathrm{H}), 3.10-3.26(\mathrm{~m}, 2 \mathrm{H}), 3.30(\mathrm{dd}, J=13.2,3.3 \mathrm{~Hz}, 1 \mathrm{H})$, 
3.94 (dd, $J=8.4,6.2 \mathrm{~Hz}, 1 \mathrm{H}), 4.05$ (ddd, $J=10.7,5.0,2.9 \mathrm{~Hz}, 1 \mathrm{H}), 4.11$ (dd, $J=8.4,6.6 \mathrm{~Hz}, 1 \mathrm{H}), 4.15-$ $4.26(\mathrm{~m}, 2 \mathrm{H}), 4.32$ (apparent td, $J=6.6,5.1 \mathrm{~Hz}, 1 \mathrm{H}), 4.66$ (apparent ddt, $J=10.0,6.9,3.3 \mathrm{~Hz}, 1 \mathrm{H}$ ), 7.17$7.23(\mathrm{~m}, 2 \mathrm{H}), 7.24-7.39(\mathrm{~m}, 3 \mathrm{H}) ;{ }^{13} \mathrm{C} \mathrm{NMR}\left(\mathrm{CDCl}_{3}, 75 \mathrm{MHz}\right) \delta 25.3\left(\mathrm{CH}_{3}\right), 26.3\left(\mathrm{CH}_{3}\right), 28.1\left(\mathrm{CH}_{2}\right), 32.6$ $\left(\mathrm{CH}_{2}\right), 38.0\left(\mathrm{CH}_{2}\right), 55.3(\mathrm{CH}), 61.6(\mathrm{CH}), 66.4\left(\mathrm{CH}_{2}\right), 78.4(\mathrm{CH}), 110.3(\mathrm{C}), 127.5(\mathrm{CH}), 129.1(\mathrm{CH})$, $129.5(\mathrm{CH}), 135.3(\mathrm{C}), 153.5(\mathrm{C}), 172.3(\mathrm{C})$; IR $\vee 3015(\mathrm{w}), 2975(\mathrm{w}), 2925(\mathrm{w}), 1785$ (s), $1695(\mathrm{~s}), 1480$ (w), $1455(\mathrm{~m}), 1385(\mathrm{~s}), 1280(\mathrm{~m}), 1210(\mathrm{~s}), 1065(\mathrm{~m}), 1025(\mathrm{~m}), 975(\mathrm{~m}), 840(\mathrm{~m}), 745(\mathrm{~m}), 700(\mathrm{~m}) \mathrm{cm}^{-}$

${ }^{1}$. Our analytical data matched those reported in the literature.

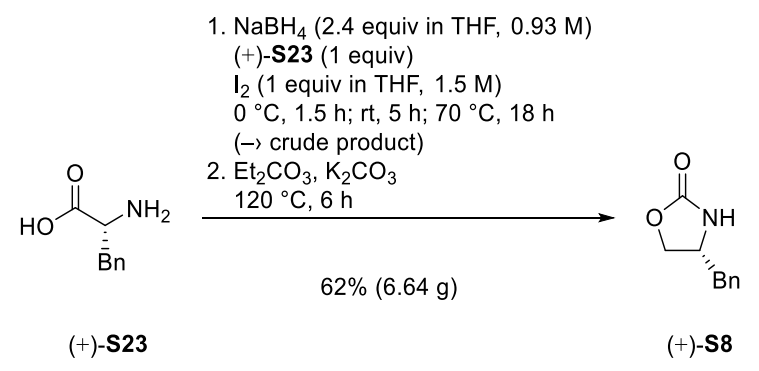

Oxazolidinone (+)-S8. ${ }^{10,11}$ Note: Slightly modified and optimized procedure. To a stirred solution of sodium borohydride $\left(\mathrm{NaBH}_{4}, 37.83 \mathrm{~g} / \mathrm{mol}, 5.5 \mathrm{~g}, 145.39 \mathrm{mmol}, 2.4\right.$ equiv) in THF (157 mL, $\left.0.93 \mathrm{M}\right)$ at 0 ${ }^{\circ} \mathrm{C}$ was added $D$-(+)-phenylalanine $\mathbf{S 2 3}\left(\mathrm{C}_{9} \mathrm{H}_{11} \mathrm{NO}_{2}, 165.19 \mathrm{~g} / \mathrm{mol}, 10 \mathrm{~g}, 60.54 \mathrm{mmol}, 1\right.$ equiv) in one portion to afford a white suspension. After being stirred for $5 \mathrm{~min}$ at $0{ }^{\circ} \mathrm{C}$, a purple solution of iodine $\left(\mathrm{I}_{2}\right.$, $253.81 \mathrm{~g} / \mathrm{mol}, 15.37 \mathrm{~g}, 60.56 \mathrm{mmol}, 1$ equiv) in THF $(42.5 \mathrm{~mL}, 1.5 \mathrm{M})$ (overall: $0.3 \mathrm{M}$ in phenylalanine in THF) was added dropwise over a period of $1.5 \mathrm{~h}$ at $0{ }^{\circ} \mathrm{C}$ to afford a white suspension. After being stirred for $5 \mathrm{~h}$ at ambient temperature, the white suspension was placed in a pre-heated oil bath $\left(70{ }^{\circ} \mathrm{C}\right)$, and stirring was continued for $18 \mathrm{~h}$. The resulting white suspension was cooled to ambient temperature and was slowly diluted by the addition of $\mathrm{MeOH}$ until a clear solution was obtained. Removal of all volatiles under reduced pressure afforded a white paste which was diluted by the addition of $\mathrm{KOH}(20 \% \mathrm{~m} / \mathrm{m}$ in water, $85 \mathrm{~mL}$ ). The resulting clear solution was stirred for $16.5 \mathrm{~h}$ at ambient temperature and was subsequently diluted by the addition of $\mathrm{CH}_{2} \mathrm{Cl}_{2}$. The resulting biphasic mixture was transferred into a separatory funnel using $\mathrm{CH}_{2} \mathrm{Cl}_{2}$ for rinsing. The phases were separated, and the aqueous layer was extracted with $\mathrm{CH}_{2} \mathrm{Cl}_{2}(6 \times)$. The combined organic layers were dried $\left(\mathrm{MgSO}_{4}\right)$. Removal of all volatiles under reduced pressure delivered a white solid $(9.99 \mathrm{~g})$, presumably $D-(+)$-phenylalaninol, which was used without proof of structure or of purity.

To a solution of the white solid $(9.99 \mathrm{~g})$ in diethyl carbonate $\left(\mathrm{Et}_{2} \mathrm{CO}_{3}, 118.13 \mathrm{~g} / \mathrm{mol}, 0.975 \mathrm{~g} / \mathrm{mL}, 8.8 \mathrm{~mL}\right.$, $8.58 \mathrm{~g}, 72.63 \mathrm{mmol})$ was added potassium carbonate $\left(\mathrm{K}_{2} \mathrm{CO}_{3}, 138.2 \mathrm{~g} / \mathrm{mol}, 0.84 \mathrm{~g}, 6.08 \mathrm{mmol}\right)$ to afford a white suspension. The suspension was placed in a pre-heated oil bath $\left(120^{\circ} \mathrm{C}\right)$. Ethanol was removed by distillation as it was formed. After being stirred for $6 \mathrm{~h}$ at $120^{\circ} \mathrm{C}{ }^{\circ} \mathrm{C}$, the white suspension was cooled to ambient temperature and was diluted by the addition of diethyl ether. Filtration through Celite ${ }^{\circledR}$ and subsequent rinsing with diethyl ether $(6 \times)$ afforded a clear solution. After removal of the volatiles under reduced pressure $\left(40{ }^{\circ} \mathrm{C}, 400 \mathrm{mbar}\right)$, water was added, and the resulting biphasic mixture was transferred into a separatory funnel using diethyl ether for rinsing. The phases were separated, and the organic layer was washed with saturated aqueous $\mathrm{NaHCO}_{3}$ solution $(3 \times)$. The organic layer was dried $\left(\mathrm{MgSO}_{4}\right)$. Removal of all volatiles under reduced pressure and subsequent purification of the clear oil by flash chromatography (cyclohexane-ethyl acetate, 5:1 to 1:1) delivered (+)-S8 $\left(\mathrm{C}_{10} \mathrm{H}_{11} \mathrm{NO}_{2}, 177.2 \mathrm{~g} / \mathrm{mol}, 6.64\right.$ $\mathrm{g}, 37.47 \mathrm{mmol}, 62 \%$ ) as a white solid. $\mathrm{R}_{\mathrm{f}} 0.31$ (cyclohexane-ethyl acetate, $1: 2$ ); m.p. $86.5{ }^{\circ} \mathrm{C} ;[\alpha]_{\mathrm{D}}{ }^{20}=$ +61.0 $\left(c=1, \mathrm{CHCl}_{3}\right) ;{ }^{1} \mathrm{H} \mathrm{NMR}\left(\mathrm{CDCl}_{3}, 400 \mathrm{MHz}\right) \delta 2.81-2.94(\mathrm{~m}, 2 \mathrm{H}), 4.04-4.17(\mathrm{~m}, 2 \mathrm{H}), 4.43$ (apparent t, $J=8.2 \mathrm{~Hz}, 1 \mathrm{H}), 5.94$ (br. s, $1 \mathrm{H}), 7.15-7.20(\mathrm{~m}, 2 \mathrm{H}), 7.24-7.30(\mathrm{~m}, 1 \mathrm{H}), 7.30-7.37$ (m, 2H); ${ }^{13} \mathrm{C} \mathrm{NMR}\left(\mathrm{CDCl}_{3}, 101 \mathrm{MHz}\right) \delta 41.5\left(\mathrm{CH}_{2}\right), 53.9(\mathrm{CH}), 69.7\left(\mathrm{CH}_{2}\right), 127.3(\mathrm{CH}), 129.1(\mathrm{CH}), 129.1(\mathrm{CH})$, $136.0(\mathrm{C}), 159.6(\mathrm{C}) ; \mathrm{IR} \vee 3280(\mathrm{~m}), 2925(\mathrm{w}), 1960$ (w), 1750 (s), $1710(\mathrm{~s}), 1455$ (w), $1405(\mathrm{~m}), 1365$ (w), $1245(\mathrm{~m}), 1095(\mathrm{~m}), 1065(\mathrm{~m}), 1020$ (s), $945(\mathrm{~m}), 900(\mathrm{w}), 760(\mathrm{~m}), 710(\mathrm{~s}), 615(\mathrm{~m}), 525(\mathrm{~m}) \mathrm{cm}^{-1}$. Our analytical data are in accordance to those reported in the literature. 


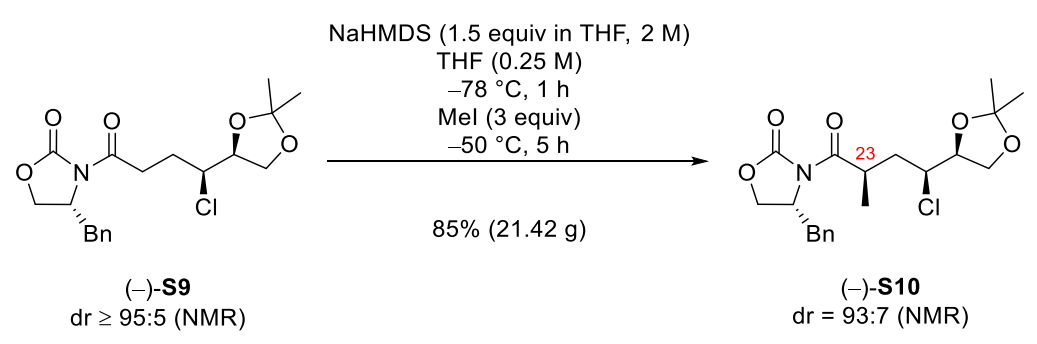

Methylated Imide (-)-S10. ${ }^{8}$ To a stirred solution of the imide (-)-S9 $\left(\mathrm{C}_{19} \mathrm{H}_{24} \mathrm{ClNO}_{5}, 381.85 \mathrm{~g} / \mathrm{mol}, 24.21\right.$ $\mathrm{g}, 63.4 \mathrm{mmol}, 1$ equiv) in THF $(254 \mathrm{~mL}, 0.25 \mathrm{M})$ at $-78{ }^{\circ} \mathrm{C}$ was added sodium bis(trimethylsilyl)amide (NaHMDS, $\mathrm{C}_{6} \mathrm{H}_{18} \mathrm{NNaSi}_{2}, 2 \mathrm{M}$ in THF, $47.55 \mathrm{~mL}, 95.1 \mathrm{mmol}, 1.5$ equiv) to afford a yellow solution. After being stirred for $1 \mathrm{~h}$ at $-78{ }^{\circ} \mathrm{C}$, the resulting white suspension was warmed to $-50{ }^{\circ} \mathrm{C}$. Iodomethane $\left(\mathrm{CH}_{3} \mathrm{I}, 141.94 \mathrm{~g} / \mathrm{mol}, 2.28 \mathrm{~g} / \mathrm{mL}, 11.84 \mathrm{~mL}, 27 \mathrm{~g}, 190.22 \mathrm{mmol}, 3\right.$ equiv) was added at $-50{ }^{\circ} \mathrm{C}$ to afford a yellow solution. After being stirred for $5 \mathrm{~h}$ at $-50{ }^{\circ} \mathrm{C}$, the yellow reaction mixture was diluted by the addition of saturated aqueous $\mathrm{NH}_{4} \mathrm{Cl}$ solution. The resulting biphasic mixture was transferred into a separatory funnel using diethyl ether for rinsing. The phases were separated, and the aqueous layer was extracted with diethyl ether (4x). The combined organic layers were dried $\left(\mathrm{MgSO}_{4}\right)$. Removal of all volatiles under reduced pressure and subsequent purification of the yellow oil by flash chromatography (cyclohexane-ethyl acetate, 50:1 to 20:1) delivered an inseparable mixture of diastereomers of (-)-S10 $\left(\mathrm{C}_{20} \mathrm{H}_{26} \mathrm{ClNO}_{5}, 395.88 \mathrm{~g} / \mathrm{mol}, 21.42 \mathrm{~g}, 54.11 \mathrm{mmol}, 85 \%\right.$, dr = 93:7 according to NMR evaluation $)$ as a viscous clear oil. The ratio of diastereomers was determined by integration of the ${ }^{1} \mathrm{H}$ NMR signals at 2.71 ppm (minor) and $2.79 \mathrm{ppm}$ (major). The absolute configuration of 23- $\mathrm{CH}$ was assigned in accordance with the accepted stereochemical model for the asymmetric induction by the chiral auxiliary. $R_{\mathrm{f}} 0.38$ (cyclohexane-ethyl acetate, $2: 1) ;[\alpha]_{\mathrm{D}}{ }^{20}=-64.5\left(c=1, \mathrm{CHCl}_{3}\right)$; NMR data are reported for the major diastereomer: ${ }^{1} \mathrm{H}$ NMR $\left(\mathrm{CDCl}_{3}, 500 \mathrm{MHz}\right) \delta 1.30(\mathrm{~d}, J=7.0 \mathrm{~Hz}, 3 \mathrm{H}), 1.38(\mathrm{~s}, 3 \mathrm{H}), 1.47(\mathrm{~s}, 3 \mathrm{H}), 1.73-$ $1.82(\mathrm{~m}, 1 \mathrm{H}), 2.24-2.32(\mathrm{~m}, 1 \mathrm{H}), 2.79(\mathrm{dd}, J=13.4,9.4 \mathrm{~Hz}, 1 \mathrm{H}), 3.22(\mathrm{dd}, J=13.3,2.3 \mathrm{~Hz}, 1 \mathrm{H}), 3.84$ $3.94(\mathrm{~m}, 2 \mathrm{H}), 4.01-4.13(\mathrm{~m}, 2 \mathrm{H}), 4.13-4.21(\mathrm{~m}, 1 \mathrm{H}), 4.21-4.28(\mathrm{~m}, 2 \mathrm{H}), 4.65-4.73(\mathrm{~m}, 1 \mathrm{H}), 7.16-7.24$ $(\mathrm{m}, 2 \mathrm{H}), 7.24-7.30(\mathrm{~m}, 1 \mathrm{H}), 7.30-7.36(\mathrm{~m}, 2 \mathrm{H}) ;{ }^{13} \mathrm{C} \mathrm{NMR}\left(\mathrm{CDCl}_{3}, 126 \mathrm{MHz}\right) \delta 18.8\left(\mathrm{CH}_{3}\right), 25.3\left(\mathrm{CH}_{3}\right)$, $26.3\left(\mathrm{CH}_{3}\right), 35.7(\mathrm{CH}), 37.0\left(\mathrm{CH}_{2}\right), 38.0\left(\mathrm{CH}_{2}\right), 55.3(\mathrm{CH}), 60.7(\mathrm{CH}), 66.3\left(\mathrm{CH}_{2}\right), 66.6\left(\mathrm{CH}_{2}\right), 78.7(\mathrm{CH})$, $110.2(\mathrm{C}), 127.5(\mathrm{CH}), 129.1(\mathrm{CH}), 129.6(\mathrm{CH}), 135.2(\mathrm{C}), 152.8(\mathrm{C}), 176.0(\mathrm{C}) ; \mathrm{IR} \vee 3085(\mathrm{~m}), 3060$ (m), 3030 (s), 2985 (s), 1790 (s), 1695 (s), 1605 (m), 1480 (s), 1455 (s), 1385 (s), 1220 (s), 1055 (s), 970 $(\mathrm{s}), 920(\mathrm{~m}), 850(\mathrm{~s}), 760(\mathrm{~s}), 705(\mathrm{~s}), 665(\mathrm{~m}), 565(\mathrm{~m}) \mathrm{cm}^{-1}$. Our analytical data are in accordance to those reported in the literature.
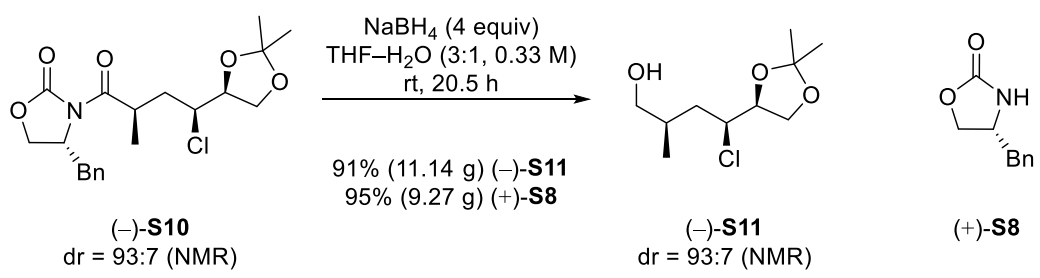

Alcohol (-)-S11. ${ }^{8}$ To a stirred solution of a diastereomeric mixture $(\mathrm{dr}=93: 7)$ of the methylated imide $(-$ )-S10 $\left(\mathrm{C}_{20} \mathrm{H}_{26} \mathrm{ClNO}_{5}, 395.88 \mathrm{~g} / \mathrm{mol}, 21.69 \mathrm{~g}, 54.79 \mathrm{mmol}, 1\right.$ equiv) in water (41.5 mL) and THF (124.5 $\mathrm{mL}$ ) (overall: $0.33 \mathrm{M})$ at ambient temperature was added sodium borohydride $\left(\mathrm{NaBH}_{4}, 37.83 \mathrm{~g} / \mathrm{mol}, 8.36\right.$ $\mathrm{g}, 220.99 \mathrm{mmol}, 4$ equiv) in three portions over a period of $5 \mathrm{~min}$ to afford a colorless cloudy solution. After being stirred for $20.5 \mathrm{~h}$ at ambient temperature, the cloudy reaction mixture was diluted by the slow addition of saturated aqueous $\mathrm{NH}_{4} \mathrm{Cl}$ solution. The resulting biphasic mixture was transferred into a separatory funnel using diethyl ether for rinsing. The phases were separated, and the aqueous layer was extracted with diethyl ether $(4 \times)$. The combined organic layers were dried $\left(\mathrm{MgSO}_{4}\right)$. Removal of all volatiles under reduced pressure and subsequent purification of the colorless oil by flash chromatography (cyclohexane-ethyl acetate, 10:1 to 1:1) delivered an inseparable mixture of diastereomers of $(-)$-S11 $\left(\mathrm{C}_{10} \mathrm{H}_{19} \mathrm{ClO}_{3}, 222.71 \mathrm{~g} / \mathrm{mol}, 11.14 \mathrm{~g}, 50.02 \mathrm{mmol}, 91 \%, \mathrm{dr}=93: 7\right.$ according to NMR evaluation $)$ as a clear colorless oil, and (+)-S8 $\left(\mathrm{C}_{10} \mathrm{H}_{11} \mathrm{NO}_{2}, 177.2 \mathrm{~g} / \mathrm{mol}, 9.27 \mathrm{~g}, 52.31 \mathrm{mmol}, 95 \%\right.$ auxiliary recycling) as 
a white solid. The ratio of diastereomers was determined by integration of the ${ }^{1} \mathrm{H}$ NMR signals at 0.94 $\mathrm{ppm}$ (minor) and $1.00 \mathrm{ppm}$ (major). $\mathrm{R}_{\mathrm{f}} 0.31$ (cyclohexane-ethyl acetate, $\left.2: 1\right) ;[\alpha]_{\mathrm{D}}{ }^{20}=-32.3(c=1$, $\left.\mathrm{CHCl}_{3}\right)$; NMR data are reported for the major diastereomer: ${ }^{1} \mathrm{H} \mathrm{NMR}\left(\mathrm{CDCl}_{3}, 500 \mathrm{MHz}\right) \delta 1.00(\mathrm{~d}, J=$ $6.9 \mathrm{~Hz}, 3 \mathrm{H}), 1.36$ (s, 3H), 1.46 (s, 3H), 1.57 (br. s, $1 \mathrm{H}), 1.64$ (ddd, $J=14.7,10.6,4.5 \mathrm{~Hz}, 1 \mathrm{H}), 1.82$ (ddd, $J=14.5,9.1,3.2 \mathrm{~Hz}, 1 \mathrm{H}), 1.97-2.07(\mathrm{~m}, 1 \mathrm{H}), 3.48-3.60(\mathrm{~m}, 2 \mathrm{H}), 3.88(\mathrm{dd}, J=8.5,5.3 \mathrm{~Hz}, 1 \mathrm{H}), 4.04-$ $4.11(\mathrm{~m}, 2 \mathrm{H}), 4.26$ (apparent td, $J=6.4,5.1 \mathrm{~Hz}, 1 \mathrm{H}) ;{ }^{13} \mathrm{C} \mathrm{NMR}\left(\mathrm{CDCl}_{3}, 126 \mathrm{MHz}\right) \delta 17.9\left(\mathrm{CH}_{3}\right), 25.3$ $\left(\mathrm{CH}_{3}\right), 26.3\left(\mathrm{CH}_{3}\right), 32.6(\mathrm{CH}), 37.4\left(\mathrm{CH}_{2}\right), 60.8(\mathrm{CH}), 66.5\left(\mathrm{CH}_{2}\right), 66.8\left(\mathrm{CH}_{2}\right), 78.6(\mathrm{CH}), 110.2(\mathrm{C})$; IR v 3440 (s), 2985 (s), 2960 (s), 2935 (s), 1455 (s), 1370 (s), 1215 (s), 1055 (s), 855 (s), 680 (w) cm ${ }^{-1}$. Our analytical data are in accordance to those reported in the literature.

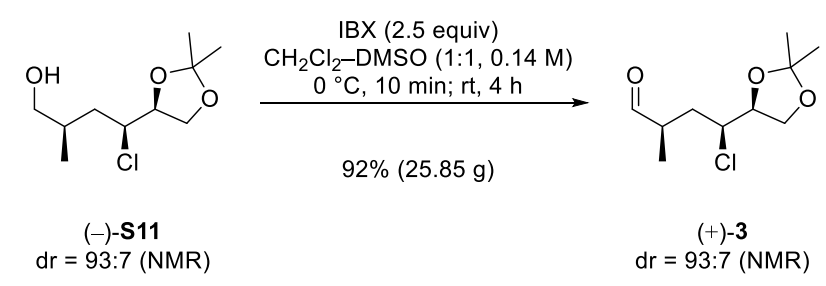

Aldehyde (+)-3. ${ }^{8}$ Note: The reaction was carried out in parallel in five batches. To each of the five colorless solutions of a diastereomeric mixture $(\mathrm{dr}=93: 7)$ of the alcohol $(-)-\mathbf{S 1 1}\left(\mathrm{C}_{10} \mathrm{H}_{19} \mathrm{ClO}_{3}, 222.71\right.$ $\mathrm{g} / \mathrm{mol}, 28.5 \mathrm{~g}$ [5×5.7 g], $127.97 \mathrm{mmol}, 1$ equiv) in $\mathrm{CH}_{2} \mathrm{Cl}_{2}(450 \mathrm{~mL}$ [5×90 mL]) and DMSO $(450 \mathrm{~mL}$ [5×90 mL]) (overall: $0.14 \mathrm{M}$ ) at $0{ }^{\circ} \mathrm{C}$ was added 2-iodoxybenzoic acid (IBX, $\mathrm{C}_{7} \mathrm{H}_{5} \mathrm{IO}_{4}, 280.02 \mathrm{~g} / \mathrm{mol}, 89.6$ $\mathrm{g}[5 \times 17.92 \mathrm{~g}], 319.98 \mathrm{mmol}, 2.5$ equiv) to afford five white suspensions. After being stirred for $10 \mathrm{~min}$ at $0{ }^{\circ} \mathrm{C}$ and subsequently $4 \mathrm{~h}$ at ambient temperature, the five white suspensions were diluted by the slow addition of saturated aqueous $\mathrm{Na}_{2} \mathrm{~S}_{2} \mathrm{O}_{3}$ solution at $0{ }^{\circ} \mathrm{C}$. After being stirred for 20 min at ambient temperature, the resulting five clear colorless biphasic mixtures were transferred into a single separatory funnel using $\mathrm{CH}_{2} \mathrm{Cl}_{2}$ for rinsing. The phases were separated, and the aqueous layer was extracted with $\mathrm{CH}_{2} \mathrm{Cl}_{2}(3 \times)$. The combined organic layers were transferred into a separatory funnel and washed with saturated aqueous $\mathrm{NaCl}$ solution $(2 \times)$. The combined organic layers were dried $\left(\mathrm{MgSO}_{4}\right)$. Removal of all volatiles under reduced pressure and subsequent purification of the slightly yellow oil by flash chromatography (cyclohexane-ethyl acetate, 20:1 to 10:1) delivered an inseparable mixture of diastereomers of (+)-3 $\left(\mathrm{C}_{10} \mathrm{H}_{17} \mathrm{ClO}_{3}, 220.69 \mathrm{~g} / \mathrm{mol}, 25.85 \mathrm{~g}, 117.13 \mathrm{mmol}, 91 \%, \mathrm{dr}=93: 7\right.$ according to NMR evaluation) as a clear colorless oil. The ratio of diastereomers was determined by integration of the ${ }^{1} \mathrm{H}$ NMR signals at $1.66 \mathrm{ppm}$ (minor) and $1.74 \mathrm{ppm}$ (major). $\mathrm{R}_{\mathrm{f}} 0.46$ (cyclohexane-ethyl acetate, 2:1); $[\alpha]_{\mathrm{D}}^{20}=+16.3\left(c=1, \mathrm{CHCl}_{3}\right)$; $\mathrm{NMR}$ data are reported for the major diastereomer: ${ }^{1} \mathrm{H} \mathrm{NMR}\left(\mathrm{CDCl}_{3}, 500\right.$ MHz) $\delta 1.19(\mathrm{~d}, J=7.5 \mathrm{~Hz}, 3 \mathrm{H}), 1.36(\mathrm{~s}, 3 \mathrm{H}), 1.46(\mathrm{~s}, 3 \mathrm{H}), 1.74(\mathrm{ddd}, J=14.5,11.3,3.2 \mathrm{~Hz}, 1 \mathrm{H}), 2.14$ (ddd, $J=14.6,9.8,2.6 \mathrm{~Hz}, 1 \mathrm{H}), 2.77-2.87(\mathrm{~m}, 1 \mathrm{H}), 3.91(\mathrm{dd}, J=8.5,6.3 \mathrm{~Hz}, 1 \mathrm{H}), 4.02(\mathrm{ddd}, J=11.1$, 4.6, $2.5 \mathrm{~Hz}, 1 \mathrm{H}), 4.07(\mathrm{dd}, J=8.5,6.7 \mathrm{~Hz}, 1 \mathrm{H}), 4.26$ (apparent td, $J=6.2,4.6 \mathrm{~Hz}, 1 \mathrm{H}), 9.67$ (apparent s, $1 \mathrm{H}) ;{ }^{13} \mathrm{C} \mathrm{NMR}\left(\mathrm{CDCl}_{3}, 126 \mathrm{MHz}\right) \delta 14.5\left(\mathrm{CH}_{3}\right), 25.3\left(\mathrm{CH}_{3}\right), 26.3\left(\mathrm{CH}_{3}\right), 34.8\left(\mathrm{CH}_{2}\right), 43.4(\mathrm{CH}), 60.4$ $(\mathrm{CH}), 66.5\left(\mathrm{CH}_{2}\right), 78.4(\mathrm{CH}), 110.3(\mathrm{C}), 203.8(\mathrm{CH})$; IR $\vee 2985(\mathrm{~s}), 2935(\mathrm{~s}), 2885(\mathrm{~m}), 2720(\mathrm{w}), 1725$ (s), $1455(\mathrm{~m}), 1370(\mathrm{~s}), 1215(\mathrm{~s}), 1065(\mathrm{~s}), 855(\mathrm{~s}), 500(\mathrm{w}) \mathrm{cm}^{-1}$. Our analytical data are in accordance to those reported in the literature.
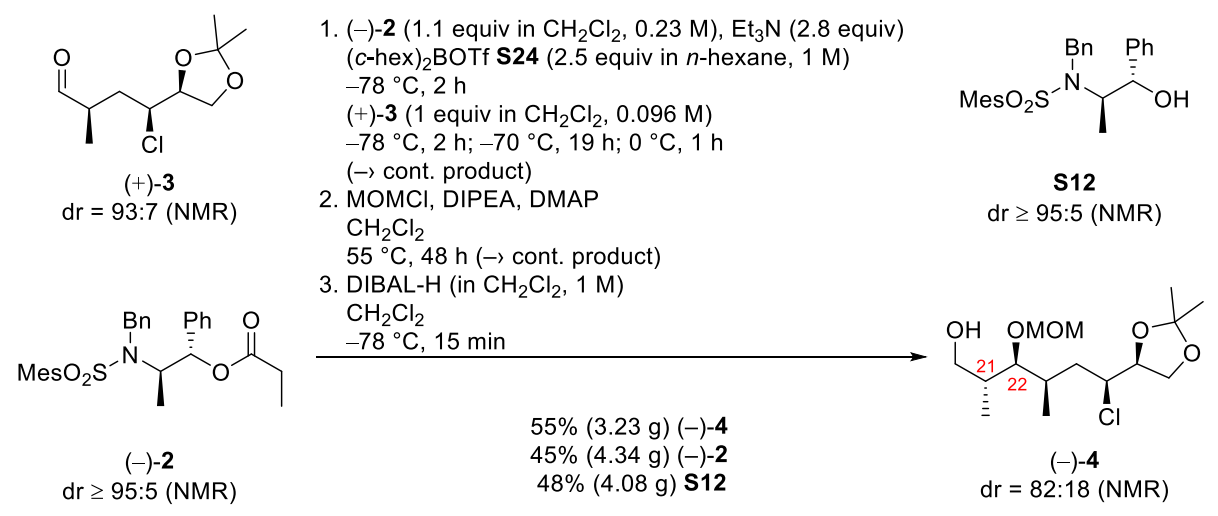
Alcohol (-)-4. To a stirred solution of the white solid (-)-2 $\left(\mathrm{C}_{28} \mathrm{H}_{33} \mathrm{NO}_{4} \mathrm{~S}, 479.64 \mathrm{~g} / \mathrm{mol}, 9.56 \mathrm{~g}, 19.93\right.$ mmol, 1.1 equiv) in $\mathrm{CH}_{2} \mathrm{Cl}_{2}(85 \mathrm{~mL}, 0.23 \mathrm{M})$ at ambient temperature was added triethylamine ( $\mathrm{Et}_{3} \mathrm{~N}$, $101.19 \mathrm{~g} / \mathrm{mol}, 0.726 \mathrm{~g} / \mathrm{mL}, 7.08 \mathrm{~mL}, 5.14 \mathrm{~g}, 50.8 \mathrm{mmol}, 2.8$ equiv) to afford a colorless solution. The solution was cooled to $-78{ }^{\circ} \mathrm{C}$ and dicylohexylboron trifuoromethanesulfonate S24 $\left((c \text {-hex })_{2}\right.$ BOTf, $\mathrm{C}_{13} \mathrm{H}_{22} \mathrm{BF}_{3} \mathrm{O}_{3} \mathrm{~S}, 1 \mathrm{M}$ in $n$-hexane, $45.31 \mathrm{~mL}, 45.31 \mathrm{mmol}, 2.5$ equiv, prepared as described below) was added dropwise to afford a slightly yellow solution. Stirring at $-78{ }^{\circ} \mathrm{C}$ was continued for $2 \mathrm{~h}$. A solution of a diastereomeric mixture $(\mathrm{dr}=93: 7)$ of the aldehyde $(+)-3\left(\mathrm{C}_{10} \mathrm{H}_{17} \mathrm{ClO}_{3}, 220.69 \mathrm{~g} / \mathrm{mol}, 4 \mathrm{~g}, 18.12\right.$ mmol, 1 equiv) in $\mathrm{CH}_{2} \mathrm{Cl}_{2}$ (189 mL, $0.096 \mathrm{M}$; overall: $0.066 \mathrm{M}$ in $\mathrm{CH}_{2} \mathrm{Cl}_{2}$ ) was subsequently added at -78 ${ }^{\circ} \mathrm{C}$ over a period of $1 \mathrm{~h}$. The reaction mixture was stirred at $-78{ }^{\circ} \mathrm{C}$ for $1 \mathrm{~h}$, at $-70{ }^{\circ} \mathrm{C}$ for $19 \mathrm{~h}$, and at $0{ }^{\circ} \mathrm{C}$ for $1 \mathrm{~h}$. The resulting slightly yellow reaction mixture was diluted by the addition of aqueous phosphate buffer $(\mathrm{pH} 7,80 \mathrm{~mL})$, methanol $(80 \mathrm{~mL})$, and hydrogen peroxide $(35 \% \mathrm{~m} / \mathrm{m}$ in water, $54 \mathrm{~mL})$ at $-78{ }^{\circ} \mathrm{C}$. The slightly yellow biphasic mixture was allowed to warm to ambient temperature. After being stirred for $3 \mathrm{~h}$ at ambient temperature, the biphasic mixture was transferred into a beaker using $\mathrm{CH}_{2} \mathrm{Cl}_{2}$ for rinsing. The slightly yellow biphasic mixture was diluted by the addition of saturated aqueous $\mathrm{Na}_{2} \mathrm{~S}_{2} \mathrm{O}_{3}$ solution at $0{ }^{\circ} \mathrm{C}$. After being stirred for $1 \mathrm{~h}$ at $0{ }^{\circ} \mathrm{C}$, the resulting slightly yellow biphasic mixture was transferred into a separatory funnel using $\mathrm{CH}_{2} \mathrm{Cl}_{2}$ for rinsing. The phases were separated, and the aqueous layer was extracted with $\mathrm{CH}_{2} \mathrm{Cl}_{2}(4 \times)$. The combined organic layers were dried $\left(\mathrm{MgSO}_{4}\right)$. Removal of all volatiles under reduced pressure and attempted purification of the slightly yellow oil by flash chromatography (cyclohexane-ethyl acetate, 20:1 to 1:1) delivered unconsumed (-)-2 $\left(\mathrm{C}_{28} \mathrm{H}_{33} \mathrm{NO}_{4} \mathrm{~S}, 479.64 \mathrm{~g} / \mathrm{mol}, 4.34 \mathrm{~g}\right.$, $9.05 \mathrm{mmol}, 45 \%$ substrate recovery) as a white solid and a clear colorless oil (9.6 g). NMR analysis of the clear colorless oil revealed significant but inseparable impurities of unconsumed aldehyde (+)-3, and the clear colorless oil was used without further purification.

A sealable glass pressure tube was charged with the clear colorless oil $(9.6 \mathrm{~g})$ in $\mathrm{CH}_{2} \mathrm{Cl}_{2}(185 \mathrm{~mL})$ to afford a colorless solution. Chloromethyl methyl ether $\left(\mathrm{MOMCl}, \mathrm{C}_{2} \mathrm{H}_{5} \mathrm{ClO}, 80.51 \mathrm{~g} / \mathrm{mol}, 1.06 \mathrm{~g} / \mathrm{mL}, 4.16\right.$ $\mathrm{mL}, 4.41 \mathrm{~g}, 54.78 \mathrm{mmol}$ ), $N, N$-diisopropylethylamine (DIPEA, $\mathrm{C}_{8} \mathrm{H}_{19} \mathrm{~N}, 129.25 \mathrm{~g} / \mathrm{mol}, 0.742 \mathrm{~g} / \mathrm{mL}, 6.99$ $\mathrm{mL}, 5.19 \mathrm{~g}, 40.15 \mathrm{mmol}$ ), and 4-(dimethylamino)pyridine (DMAP, $\mathrm{C}_{7} \mathrm{H}_{10} \mathrm{~N}_{2}, 122.17 \mathrm{~g} / \mathrm{mol}, 1.67 \mathrm{~g}, 13.67$ mmol) were added at ambient temperature to afford a colorless solution. The tube was sealed with a Teflon screw cap and placed in a pre-heated oil bath $\left(55^{\circ} \mathrm{C}\right)$. After being stirred for $19 \mathrm{~h}$ at $55^{\circ} \mathrm{C}$, the resulting orange solution was cooled to ambient temperature. $\mathrm{MOMCl}\left(\mathrm{C}_{2} \mathrm{H}_{5} \mathrm{ClO}, 80.51 \mathrm{~g} / \mathrm{mol}, 1.06\right.$ $\mathrm{g} / \mathrm{mL}, 4.16 \mathrm{~mL}, 4.41 \mathrm{~g}, 54.78 \mathrm{mmol})$, DIPEA $\left(\mathrm{C}_{8} \mathrm{H}_{19} \mathrm{~N}, 129.25 \mathrm{~g} / \mathrm{mol}, 0.742 \mathrm{~g} / \mathrm{mL}, 6.99 \mathrm{~mL}, 5.19 \mathrm{~g}, 40.15\right.$ mmol), and DMAP $\left(\mathrm{C}_{7} \mathrm{H}_{10} \mathrm{~N}_{2}, 122.17 \mathrm{~g} / \mathrm{mol}, 1.67 \mathrm{~g}, 13.67 \mathrm{mmol}\right)$ were added at ambient temperature to afford an orange solution. The tube was sealed with a Teflon screw cap and placed in a pre-heated oil bath $\left(55^{\circ} \mathrm{C}\right)$. After being stirred for $29 \mathrm{~h}$ at $55^{\circ} \mathrm{C}$, the resulting orange solution was diluted by the addition of aqueous phosphate buffer $(\mathrm{pH} 7)$ and saturated aqueous $\mathrm{NH}_{4} \mathrm{Cl}$ solution $(v / v=1: 1)$ at ambient temperature. The resulting orange biphasic mixture was transferred into a separatory funnel using $\mathrm{CH}_{2} \mathrm{Cl}_{2}$ for rinsing. The phases were separated, and the aqueous layer was extracted with $\mathrm{CH}_{2} \mathrm{Cl}_{2}(4 \times)$. The combined organic layers were dried $\left(\mathrm{MgSO}_{4}\right)$. Removal of all volatiles under reduced pressure and attempted purification of the orange oil by flash chromatography (cyclohexane-ethyl acetate, 20:1 to 5:1) delivered a slightly yellow oil $(9.04 \mathrm{~g})$. NMR analysis of the slightly yellow oil revealed significant but inseparable impurities of unconsumed aldehyde (+)-3, and the slightly yellow oil was used without further purification.

To a stirred solution of the slightly yellow oil $(9.04 \mathrm{~g})$ in $\mathrm{CH}_{2} \mathrm{Cl}_{2}(364 \mathrm{~mL})$ at $-78{ }^{\circ} \mathrm{C}$ was added diisobutylaluminium hydride (DIBAL-H, $\mathrm{C}_{8} \mathrm{H}_{19} \mathrm{Al}, 1 \mathrm{M}$ in $\mathrm{CH}_{2} \mathrm{Cl}_{2}, 72.87 \mathrm{~mL}, 72.87 \mathrm{mmol}$ ) to afford a colorless solution. After being stirred for $15 \mathrm{~min}$ at $-78{ }^{\circ} \mathrm{C}$, the resulting colorless solution was diluted by the slow addition of saturated aqueous $\mathrm{NH}_{4} \mathrm{Cl}$ solution and saturated aqueous potassium sodium tartrate solution $(v / v=1: 2)$ at $-78{ }^{\circ} \mathrm{C}$. The cooling bath was removed, and the colorless biphasic mixture was allowed to warm to ambient temperature. After being stirred for $12 \mathrm{~h}$ at ambient temperature, the resulting colorless biphasic mixture was transferred into a separatory funnel using $\mathrm{CH}_{2} \mathrm{Cl}_{2}$ for rinsing. The phases were separated, and the aqueous layer was extracted with $\mathrm{CH}_{2} \mathrm{Cl}_{2}(4 \times)$. The combined organic layers were dried $\left(\mathrm{MgSO}_{4}\right)$. Removal of all volatiles under reduced pressure delivered a colorless oil. Purification of the colorless oil by flash chromatography (cyclohexane-ethyl acetate, 10:1 to 1:2) yielded an inseparable 
mixture of diastereomers of (-)-4 $\left(\mathrm{C}_{15} \mathrm{H}_{29} \mathrm{ClO}_{5}, 324.84 \mathrm{~g} / \mathrm{mol}, 3.23 \mathrm{~g}, 9.94 \mathrm{mmol}, 55 \%\right.$, $\mathrm{dr}=82: 18$ according to NMR evaluation) as a clear colorless oil, and $\mathbf{S 1 2}{ }^{12}\left(\mathrm{C}_{25} \mathrm{H}_{29} \mathrm{NO}_{3} \mathrm{~S}, 423.57 \mathrm{~g} / \mathrm{mol}, 4.08 \mathrm{~g}, 9.63\right.$ mmol, 48\% auxiliary recycling, $\mathrm{dr} \geq 95: 5$ according to NMR evaluation) as a white solid. (-)-4: The ratio of diastereomers was determined by integration of the ${ }^{1} \mathrm{H}$ NMR signals at $0.95 \mathrm{ppm}$ (major) and $1.00 \mathrm{ppm}$ (minor). The absolute configuration of $21-\mathrm{CH}$ and $22-\mathrm{CH}$ was tentatively assigned and later confirmed by the interpretation of a NOE experiment. $\mathrm{R}_{\mathrm{f}} 0.17$ (cyclohexane-ethyl acetate, $\left.5: 1\right) ;[\alpha]_{\mathrm{D}}{ }^{20}=-27.1(c=1$, $\left.\mathrm{CHCl}_{3}\right)$; NMR data are reported for the major diastereomer: ${ }^{1} \mathrm{H} \mathrm{NMR}\left(\mathrm{CDCl}_{3}, 500 \mathrm{MHz}\right) \delta 0.93-0.97(\mathrm{~m}$, $6 \mathrm{H}), 1.37(\mathrm{~s}, 3 \mathrm{H}), 1.46(\mathrm{~s}, 3 \mathrm{H}), 1.59$ (ddd, $J=15.3,11.0,3.9 \mathrm{~Hz}, 1 \mathrm{H}), 1.80-1.88(\mathrm{~m}, 1 \mathrm{H}), 1.91$ (ddd, $J=$ 14.0, 10.2, 3.9 Hz, 1H), 2.06-2.15 (m, 1H), 2.48 (br. s, 1H), 3.38-3.42 (m, 4H), 3.55-3.60 (m, 1H), 3.71$3.76(\mathrm{~m}, 1 \mathrm{H}), 3.91(\mathrm{dd}, J=8.5,6.4 \mathrm{~Hz}, 1 \mathrm{H}), 4.04-4.10(\mathrm{~m}, 2 \mathrm{H}), 4.26$ (apparent td, $J=6.5,6.0 \mathrm{~Hz}, 1 \mathrm{H})$, 4.65-4.70 (m, 2H); ${ }^{13} \mathrm{C} \mathrm{NMR}\left(\mathrm{CDCl}_{3}, 126 \mathrm{MHz}\right) \delta 14.7\left(\mathrm{CH}_{3}\right), 14.9\left(\mathrm{CH}_{3}\right), 25.3\left(\mathrm{CH}_{3}\right), 26.3\left(\mathrm{CH}_{3}\right), 31.9$ $(\mathrm{CH}), 37.2\left(\mathrm{CH}_{2}\right), 38.2(\mathrm{CH}), 56.2\left(\mathrm{CH}_{3}\right), 60.5(\mathrm{CH}), 65.7\left(\mathrm{CH}_{2}\right), 66.3\left(\mathrm{CH}_{2}\right), 78.7(\mathrm{CH}), 83.5(\mathrm{CH}), 99.0$ $\left(\mathrm{CH}_{2}\right), 110.1(\mathrm{C})$; IR $\vee 3475(\mathrm{w}), 2935(\mathrm{w}), 1455(\mathrm{w}), 1370(\mathrm{~m}), 1255(\mathrm{w}), 1215(\mathrm{~m}), 1145(\mathrm{~m}), 1030(\mathrm{~s})$, $985(\mathrm{~m}), 915(\mathrm{~m}), 850(\mathrm{~m}), 795(\mathrm{~m}), 685(\mathrm{w}), 555(\mathrm{w}), 510(\mathrm{w}) \mathrm{cm}^{-1}$; Anal. Calcd. for $\mathrm{C}_{15} \mathrm{H}_{29} \mathrm{ClO}_{5}$ : C, 55.5; H, 9.0; Found: C, 55.6; H, 9.1. S12: $\mathrm{R}_{\mathrm{f}} 0.69$ (cyclohexane-ethyl acetate, $\left.1: 1\right) ;{ }^{1} \mathrm{H} \mathrm{NMR}\left(\mathrm{CDCl}_{3}, 500\right.$ MHz) $\delta 1.04(\mathrm{~d}, J=7.1 \mathrm{~Hz}, 3 \mathrm{H}), 2.13$ (br. s, 1H), 2.29 (s, 3H), 2.65 (s, 6H), 3.84 (q, $J=6.7 \mathrm{~Hz}, 1 \mathrm{H}), 4.55$ $(\mathrm{d}, J=16.1 \mathrm{~Hz}, 1 \mathrm{H}), 4.78(\mathrm{~d}, J=16.1 \mathrm{~Hz}, 1 \mathrm{H}), 5.00(\mathrm{~s}, 1 \mathrm{H}), 6.93(\mathrm{~s}, 2 \mathrm{H}), 7.08(\mathrm{~d}, J=7.2 \mathrm{~Hz}, 2 \mathrm{H}), 7.17-$ $7.26(\mathrm{~m}, 4 \mathrm{H}), 7.29(\mathrm{t}, J=7.4 \mathrm{~Hz}, 2 \mathrm{H}), 7.34(\mathrm{~d}, J=7.2 \mathrm{~Hz}, 2 \mathrm{H}) ;{ }^{13} \mathrm{C} \mathrm{NMR}\left(\mathrm{CDCl}_{3}, 126 \mathrm{MHz}\right) \delta 10.1$ $\left(\mathrm{CH}_{3}\right), 21.0\left(\mathrm{CH}_{3}\right), 23.2\left(\mathrm{CH}_{3}\right), 49.3\left(\mathrm{CH}_{2}\right), 59.9(\mathrm{CH}), 76.8(\mathrm{CH}), 125.7(\mathrm{CH}), 127.4(\mathrm{CH}), 127.6(\mathrm{CH})$, $127.9(\mathrm{CH}), 128.3(\mathrm{CH}), 128.8(\mathrm{CH}), 132.3(\mathrm{CH}), 133.7(\mathrm{C}), 138.8(\mathrm{C}), 140.4(\mathrm{C}), 142.3(\mathrm{C}), 142.8(\mathrm{C})$; IR v $3505(\mathrm{~m}), 3060(\mathrm{w}), 2980(\mathrm{w}), 2930(\mathrm{w}), 1600(\mathrm{~m}), 1455(\mathrm{~m}), 1305$ (s), 1145 (s), $1020(\mathrm{~s}), 855(\mathrm{~m})$, $660(\mathrm{~s}) \mathrm{cm}^{-1}$. Our analytical data are in accordance to those reported in the literature.

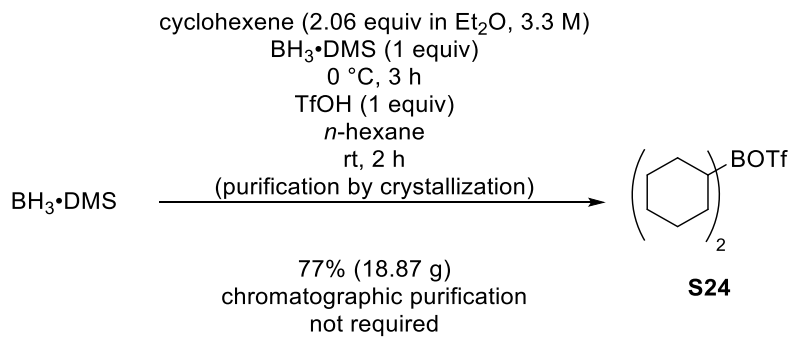

Dicylohexylboron Trifuoromethanesulfonate S24. ${ }^{13}$ Note: All actions must be performed carefully under an inert atmosphere. To a stirred solution of cyclohexene $\left(\mathrm{C}_{6} \mathrm{H}_{10}, 82.15 \mathrm{~g} / \mathrm{mol}, 0.81 \mathrm{~g} / \mathrm{mL}, 15.67\right.$ $\mathrm{mL}, 12.69 \mathrm{~g}, 154.47 \mathrm{mmol}, 2.06$ equiv) in diethyl ether $(47 \mathrm{~mL}, 3.3 \mathrm{M})$ at $0{ }^{\circ} \mathrm{C}$ was added borane dimethyl sulfide complex $\left(\mathrm{BH}_{3} \cdot{ }^{\circ} \mathrm{DMS}, \mathrm{C}_{2} \mathrm{H}_{9} \mathrm{BS}, 75.96 \mathrm{~g} / \mathrm{mol}, 0.801 \mathrm{~g} / \mathrm{mL}, 7.57 \mathrm{~mL}, 6.06 \mathrm{~g}, 94 \%\right.$ purity, $5.7 \mathrm{~g}, 75.04 \mathrm{mmol}, 1$ equiv) over a period of $15 \mathrm{~min}$ to afford a white suspension. After being stirred for 3 $\mathrm{h}$ at $0{ }^{\circ} \mathrm{C}$, all volatiles were removed under reduced pressure $\left(0{ }^{\circ} \mathrm{C}, 100 \mathrm{mbar}\right.$ to $\left.50 \mathrm{mbar}\right)$, and the flask was vented with argon to afford a white solid. To a stirred solution of the white solid in $n$-hexane $(47 \mathrm{~mL}$, $3.3 \mathrm{M}$ ) at ambient temperature was added trifluoromethanesulfonic acid $\left(\mathrm{TfOH}, \mathrm{CHF}_{3} \mathrm{O}_{3} \mathrm{~S}, 150.07 \mathrm{~g} / \mathrm{mol}\right.$, $1.71 \mathrm{~g} / \mathrm{mL}, 6.62 \mathrm{~mL}, 11.32 \mathrm{~g}, 75.43 \mathrm{mmol}, 1$ equiv) over a period of $15 \mathrm{~min}$ using a glass syringe to afford a clear colorless solution. After being stirred for $1 \mathrm{~h}$ at ambient temperature, stirring was discontinued, and the colorless solution was kept for $1 \mathrm{~h}$ at ambient temperature. The upper phase of the resulting biphasic mixture was transferred into a weighted round-bottomed flask by syringe. The round-bottomed flask was locked with a glass stopper, sealed with parafilm, and kept in a freezer $\left(-30{ }^{\circ} \mathrm{C}\right)$ for $16 \mathrm{~h}$. Precipitation of colorless crystals was observed. The solvent was subsequently removed by syringe. Remaining volatiles were evaporated under reduced pressure (ambient temperature, $0.05 \mathrm{mbar}$ ) to afford S24 (assumed to be $\mathrm{C}_{13} \mathrm{H}_{22} \mathrm{BF}_{3} \mathrm{O}_{3} \mathrm{~S}, 326.18 \mathrm{~g} / \mathrm{mol}, 18.87 \mathrm{~g}, 57.85 \mathrm{mmol}, 77 \%$ ) as white crystals. The crystals were dissolved in $n$-hexane $(58 \mathrm{~mL})$ to afford a solution $(1 \mathrm{M})$ that was immediately used as described above. 


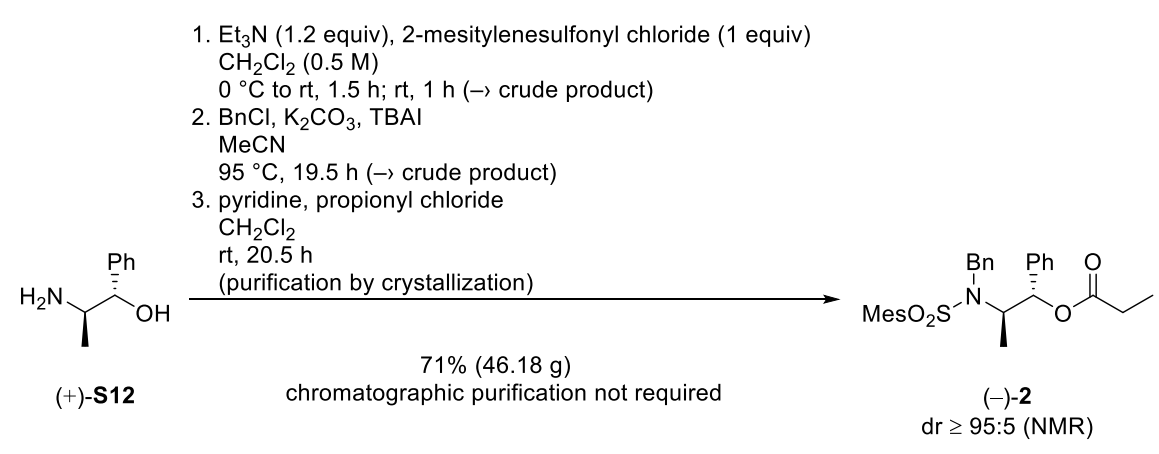

Propyl Propionate (-)-2. ${ }^{12}$ Note: Slightly modified and optimized procedure. The reaction sequence was carried out in parallel in two batches. To each of the two colorless solutions of $(1 S, 2 R)-(+)$-norephedrine S12 $\left(\mathrm{C}_{9} \mathrm{H}_{13} \mathrm{NO}, 151.21 \mathrm{~g} / \mathrm{mol}, 20.56 \mathrm{~g}\right.$ [2×10.28 g], $135.97 \mathrm{mmol}, 1$ equiv) in $\mathrm{CH}_{2} \mathrm{Cl}_{2}(272 \mathrm{~mL}$ [2×136 $\mathrm{mL}], 0.5 \mathrm{M})$ at $0{ }^{\circ} \mathrm{C}$ was added triethylamine $\left(\mathrm{Et}_{3} \mathrm{~N}, 101.19 \mathrm{~g} / \mathrm{mol}, 0.726 \mathrm{~g} / \mathrm{mL}, 22.74 \mathrm{~mL}[2 \times 11.37 \mathrm{~mL}]\right.$, $16.51 \mathrm{~g}$ [2×8.255 g], $163.16 \mathrm{mmol}, 1.2 \mathrm{equiv})$ and 2-mesitylenesulfonyl chloride $\left(\mathrm{C}_{9} \mathrm{H}_{11} \mathrm{ClO}_{2} \mathrm{~S}, 218.7\right.$ $\mathrm{g} / \mathrm{mol}, 29.74 \mathrm{~g}$ [2×14.87 g], $135.99 \mathrm{mmol}, 1$ equiv) to afford two white suspensions. The two white suspensions were allowed warming to ambient temperature over a period of $1.5 \mathrm{~h}$ and were subsequently stirred for $1 \mathrm{~h}$ at ambient temperature. The two white suspensions were diluted by the addition of diethyl ether at ambient temperature. The resulting two clear colorless solutions were transferred into a single separatory funnel using diethyl ether for rinsing and were washed successively with water, $1 \mathrm{M}$ aqueous $\mathrm{HCl}$ solution, water, saturated aqueous $\mathrm{NaHCO}_{3}$ solution, and saturated aqueous $\mathrm{NaCl}$ solution. The combined organic layers were dried $\left(\mathrm{MgSO}_{4}\right)$. Removal of all volatiles under reduced pressure delivered a highly viscos colorless oil (45.34 g), presumably the corresponding sulfonamide, which was used without proof of structure or of purity.

To each of the two colorless solutions of the highly viscos colorless oil $(45.34 \mathrm{~g}$ [ $2 \times 22.67 \mathrm{~g}])$ in acetonitrile $(258 \mathrm{~mL}[2 \times 129 \mathrm{~mL}])$ at ambient temperature was added benzyl chloride $(\mathrm{BnCl}, 126.58$ $\mathrm{g} / \mathrm{mol}, 1.1 \mathrm{~g} / \mathrm{mL}, 18.78 \mathrm{~mL}$ [2×9.39 mL], $20.66 \mathrm{~g}$ [2×10.33 g], $163.22 \mathrm{mmol}$ ), potassium carbonate $\left(\mathrm{K}_{2} \mathrm{CO}_{3}, 138.2 \mathrm{~g} / \mathrm{mol}, 22.56 \mathrm{~g}[2 \times 11.28 \mathrm{~g}], 163.24 \mathrm{mmol}\right)$, and tetrabutylammonium iodide (TBAI, $\left.\mathrm{C}_{16} \mathrm{H}_{36} \mathrm{IN}, 369.38 \mathrm{~g} / \mathrm{mol}, 0.5 \mathrm{~g}[2 \times 0.25 \mathrm{~g}], 1.35 \mathrm{mmol}\right)$ to afford two white suspensions. The two reaction flasks were placed in pre-heated oil baths $\left(95^{\circ} \mathrm{C}\right)$. After being stirred for $19.5 \mathrm{~h}$ at $95{ }^{\circ} \mathrm{C}$, the two white suspensions were allowed to cool to ambient temperature. The two white suspensions were diluted by the addition of $\mathrm{CH}_{2} \mathrm{Cl}_{2}$ at ambient temperature. The two white suspensions were filtered, and the solid white residues were washed with $\mathrm{CH}_{2} \mathrm{Cl}_{2}(4 \times)$. The two filtrates were concentrated under reduced pressure to deliver two white solids (52.05 g [26.18 g+25.87 g]), presumably the corresponding $N$-benzyl sulfonamides, which were used without proof of structure or of purity.

To each of the two colorless solutions of the white solids $\left(52.05 \mathrm{~g}\right.$ [26.18 g+25.87 g]) in $\mathrm{CH}_{2} \mathrm{Cl}_{2}(760 \mathrm{~mL}$ $[2 \times 380 \mathrm{~mL}])$ at $0{ }^{\circ} \mathrm{C}$ was added pyridine $\left(\mathrm{C}_{5} \mathrm{H}_{5} \mathrm{~N}, 79.1 \mathrm{~g} / \mathrm{mol}, 0.98 \mathrm{~g} / \mathrm{mL}, 14.26 \mathrm{~mL}[2 \times 7.13 \mathrm{~mL}], 13.97 \mathrm{~g}\right.$ [2×6.985 g], $176.61 \mathrm{mmol})$, and freshly distilled $\left(90{ }^{\circ} \mathrm{C}\right)$ propionyl chloride $\left(\mathrm{C}_{3} \mathrm{H}_{5} \mathrm{ClO}, 92.52 \mathrm{~g} / \mathrm{mol}, 1.06\right.$ $\mathrm{g} / \mathrm{mL}, 14.24 \mathrm{~mL}[2 \times 7.12 \mathrm{~mL}], 15.09 \mathrm{~g}$ [2×7.545 g], $163.1 \mathrm{mmol})$ to afford two slightly yellow solutions. After being stirred for $20.5 \mathrm{~h}$ at ambient temperature, the resulting two yellow reaction mixtures were diluted by the addition of saturated aqueous $\mathrm{NH}_{4} \mathrm{Cl}$ solution. The resulting two yellow biphasic mixtures were transferred into a single separatory funnel using $\mathrm{CH}_{2} \mathrm{Cl}_{2}$ for rinsing. The phases were separated, and the aqueous layer was extracted with $\mathrm{CH}_{2} \mathrm{Cl}_{2}(4 \times)$. The combined organic layers were dried $\left(\mathrm{MgSO}_{4}\right)$. Removal of all volatiles under reduced pressure triggered precipitation of a yellowish solid. The solid was collected by filtration and washed with cyclohexane (6×). Removal of all volatiles under reduced pressure afforded (-)-2 $\left(\mathrm{C}_{28} \mathrm{H}_{33} \mathrm{NO}_{4} \mathrm{~S}, 479.64 \mathrm{~g} / \mathrm{mol}, 46.18 \mathrm{~g}, 96.28 \mathrm{mmol}, 71 \%\right.$, dr $\geq 95: 5$ according to NMR evaluation) as a white solid sufficiently pure for characterization. $\mathrm{R}_{\mathrm{f}} 0.63$ (cyclohexane-ethyl acetate, 1:1); m.p. $148.7{ }^{\circ} \mathrm{C} ;[\alpha]_{\mathrm{D}}{ }^{20}=-9.5\left(c=1, \mathrm{CHCl}_{3}\right) ;{ }^{1} \mathrm{H} \mathrm{NMR}\left(\mathrm{CDCl}_{3}, 500 \mathrm{MHz}\right) \delta 1.03(\mathrm{t}, J=7.6 \mathrm{~Hz}, 3 \mathrm{H})$, $1.13(\mathrm{~d}, J=7.0 \mathrm{~Hz}, 3 \mathrm{H}), 2.08-2.24(\mathrm{~m}, 2 \mathrm{H}), 2.28(\mathrm{~s}, 3 \mathrm{H}), 2.52(\mathrm{~s}, 6 \mathrm{H}), 4.06$ (apparent qd, $J=6.9,4.1 \mathrm{~Hz}$, $1 \mathrm{H}), 4.61(\mathrm{~d}, J=16.8 \mathrm{~Hz}, 1 \mathrm{H}), 4.72(\mathrm{~d}, J=16.8 \mathrm{~Hz}, 1 \mathrm{H}), 5.86(\mathrm{~d}, J=3.8 \mathrm{~Hz}, 1 \mathrm{H}), 6.88(\mathrm{~s}, 2 \mathrm{H}), 6.90-6.95$ $(\mathrm{m}, 2 \mathrm{H}), 7.16-7.23(\mathrm{~m}, 4 \mathrm{H}), 7.23-7.29(\mathrm{~m}, 2 \mathrm{H}), 7.33(\mathrm{~d}, J=7.4 \mathrm{~Hz}, 2 \mathrm{H}) ;{ }^{13} \mathrm{C} \mathrm{NMR}\left(\mathrm{CDCl}_{3}, 126 \mathrm{MHz}\right) \delta$ $8.9\left(\mathrm{CH}_{3}\right), 12.9\left(\mathrm{CH}_{3}\right), 21.0\left(\mathrm{CH}_{3}\right), 23.1\left(\mathrm{CH}_{3}\right), 27.6\left(\mathrm{CH}_{2}\right), 48.3\left(\mathrm{CH}_{2}\right), 56.9(\mathrm{CH}), 78.1(\mathrm{CH}), 126.1$ 
$(\mathrm{CH}), 127.2(\mathrm{CH}), 127.5(\mathrm{CH}), 127.9(\mathrm{CH}), 128.5(\mathrm{CH}), 128.5(\mathrm{CH}), 132.3(\mathrm{CH}), 133.5(\mathrm{C}), 138.8(\mathrm{C})$, 138.8 (C), $140.3(\mathrm{C}), 142.6(\mathrm{C}), 172.7(\mathrm{C}) ; \mathrm{IR} \vee 2980(\mathrm{~m}), 1750$ (s), $1605(\mathrm{~m}), 1455$ (m), $1320(\mathrm{~s}), 1165$ $(\mathrm{s}), 1020(\mathrm{~m}), 935(\mathrm{~m}), 860(\mathrm{~s}), 765(\mathrm{~s}), 650(\mathrm{~m}), 570(\mathrm{~m}), 525(\mathrm{~m}) \mathrm{cm}^{-1}$. Our analytical data are in accordance to those reported in the literature.

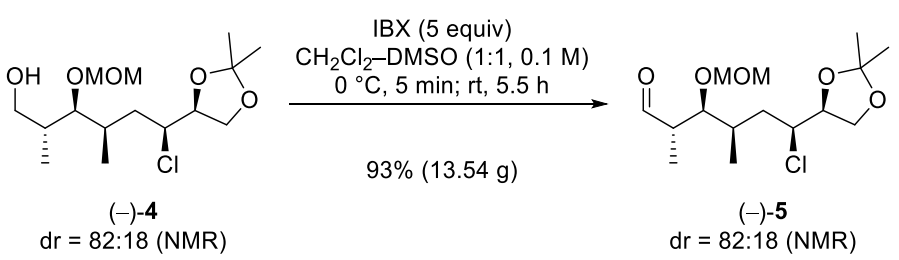

Aldehyde (-)-5. Note: The reaction was carried out in parallel in two batches. To each of the two colorless solutions of a diastereomeric mixture $(\mathrm{dr}=82: 18)$ of the alcohol $(-)-4\left(\mathrm{C}_{15} \mathrm{H}_{29} \mathrm{ClO}_{5}, 324.84\right.$ $\mathrm{g} / \mathrm{mol}, 14.64 \mathrm{~g}$ [2×7.32 g], $45.07 \mathrm{mmol}, 1$ equiv $)$ in $\mathrm{CH}_{2} \mathrm{Cl}_{2}(225 \mathrm{~mL}$ [2×112.5 mL]) and DMSO $(225 \mathrm{~mL}$ [2×112.5 mL]) (overall: $0.1 \mathrm{M}$ ) at $0{ }^{\circ} \mathrm{C}$ was added 2-iodoxybenzoic acid $\left(\mathrm{IBX}, \mathrm{C}_{7} \mathrm{H}_{5} \mathrm{IO}_{4}, 280.02 \mathrm{~g} / \mathrm{mol}\right.$, $63.08 \mathrm{~g} \mathrm{[} 2 \times 31.54 \mathrm{~g}], 225.27 \mathrm{mmol}, 5$ equiv) to afford two white suspensions. After being stirred for $5 \mathrm{~min}$ at $0{ }^{\circ} \mathrm{C}$ and subsequently for $5.5 \mathrm{~h}$ at ambient temperature, the two white suspensions were diluted by the slow addition of saturated aqueous $\mathrm{Na}_{2} \mathrm{~S}_{2} \mathrm{O}_{3}$ solution at $0{ }^{\circ} \mathrm{C}$. After being stirred for 30 min at ambient temperature, the resulting two clear colorless biphasic mixtures were transferred into a single separatory funnel using $\mathrm{CH}_{2} \mathrm{Cl}_{2}$ for rinsing. The phases were separated, and the aqueous layer was extracted with $\mathrm{CH}_{2} \mathrm{Cl}_{2}(4 \times)$. The combined organic layers were transferred into a separatory funnel and washed with saturated aqueous $\mathrm{NaCl}$ solution $(2 \times)$. The combined organic layers were dried $\left(\mathrm{MgSO}_{4}\right)$. Removal of all volatiles under reduced pressure and subsequent purification of the slightly yellow oil by flash chromatography (cyclohexane-ethyl acetate, 20:1 to 10:1) delivered an inseparable mixture of diastereomers of (-)-5 $\left(\mathrm{C}_{15} \mathrm{H}_{27} \mathrm{ClO}_{5}, 322.83 \mathrm{~g} / \mathrm{mol}, 13.54 \mathrm{~g}, 41.94 \mathrm{mmol}, 93 \%, \mathrm{dr}=82: 18\right.$ according to NMR evaluation) as a clear colorless oil. The ratio of diastereomers was determined by integration of the ${ }^{1} \mathrm{H}$ NMR signals at $3.66 \mathrm{ppm}$ (minor) and $3.72 \mathrm{ppm}$ (major). $\mathrm{R}_{\mathrm{f}} 0.4$ (cyclohexane-ethyl acetate, 2:1); $[\alpha]_{\mathrm{D}}{ }^{20}=-38.4\left(c=1, \mathrm{CHCl}_{3}\right)$; NMR data are reported for the major diastereomer: ${ }^{1} \mathrm{H} \mathrm{NMR}\left(\mathrm{CDCl}_{3}, 400\right.$ MHz) $\delta 0.98(\mathrm{~d}, J=6.9 \mathrm{~Hz}, 3 \mathrm{H}), 1.07(\mathrm{~d}, J=6.9 \mathrm{~Hz}, 3 \mathrm{H}), 1.37(\mathrm{~s}, 3 \mathrm{H}), 1.46(\mathrm{~s}, 3 \mathrm{H}), 1.61(\mathrm{ddd}, J=14.0$, 11.7, $4.7 \mathrm{~Hz}, 1 \mathrm{H}), 1.94$ (ddd, $J=14.0,9.8,3.9 \mathrm{~Hz}, 1 \mathrm{H}), 2.07-2.18(\mathrm{~m}, 1 \mathrm{H}), 2.69$ (apparent quind, $J=7.4$, $3.2 \mathrm{~Hz}, 1 \mathrm{H}), 3.33(\mathrm{~s}, 3 \mathrm{H}), 3.72(\mathrm{dd}, J=8.3,2.0 \mathrm{~Hz}, 1 \mathrm{H}), 3.91(\mathrm{dd}, J=8.3,6.4 \mathrm{~Hz}, 1 \mathrm{H}), 4.03-4.12(\mathrm{~m}$, 2H), 4.25 (apparent td, $J=6.4,4.9 \mathrm{~Hz}, 1 \mathrm{H}), 4.56-4.71(\mathrm{~m}, 2 \mathrm{H}), 9.72(\mathrm{~d}, J=2.9 \mathrm{~Hz}, 1 \mathrm{H}) ;{ }^{13} \mathrm{C} \mathrm{NMR}$ $\left(\mathrm{CDCl}_{3}, 101 \mathrm{MHz}\right) \delta 11.8\left(\mathrm{CH}_{3}\right), 14.8\left(\mathrm{CH}_{3}\right), 25.3\left(\mathrm{CH}_{3}\right), 26.3\left(\mathrm{CH}_{3}\right), 31.8(\mathrm{CH}), 36.8\left(\mathrm{CH}_{2}\right), 49.6(\mathrm{CH})$, $56.1\left(\mathrm{CH}_{3}\right), 60.5(\mathrm{CH}), 66.4\left(\mathrm{CH}_{2}\right), 78.7(\mathrm{CH}), 81.1(\mathrm{CH}), 98.2\left(\mathrm{CH}_{2}\right), 110.1(\mathrm{C}), 204.1(\mathrm{CH})$; IR v 2940 (w), $1725(\mathrm{~m}), 1455(\mathrm{w}), 1370(\mathrm{w}), 1260(\mathrm{w}), 1215(\mathrm{~m}), 1150(\mathrm{~m}), 1030(\mathrm{~s}), 920(\mathrm{~m}), 850(\mathrm{~m}), 685(\mathrm{w})$, $510(w) \mathrm{cm}^{-1}$; Anal. Calcd. for $\mathrm{C}_{15} \mathrm{H}_{27} \mathrm{ClO}_{5}$ : C, 55.8; H, 8.4; Found: C, 55.7; H, 8.4.

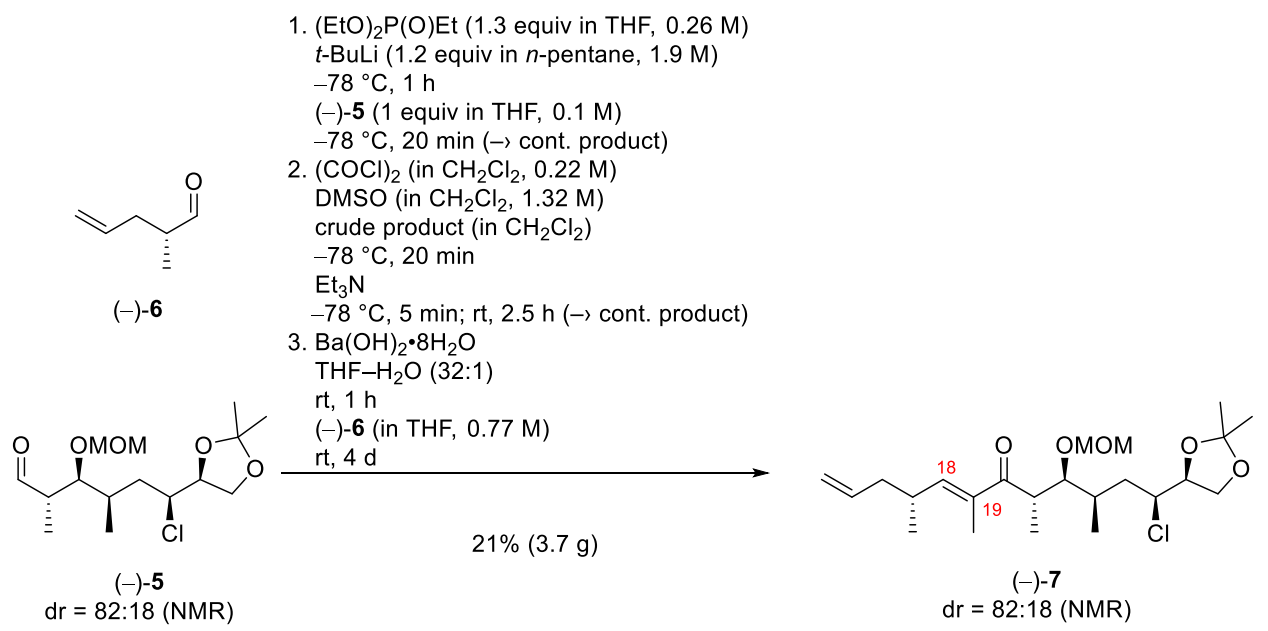

Enone (-)-7. Note: The reaction sequence was carried out in parallel in two batches. To each of the two 
colorless solutions of diethyl ethylphosphonate $\left(\mathrm{C}_{6} \mathrm{H}_{15} \mathrm{O}_{3} \mathrm{P}, 166.16 \mathrm{~g} / \mathrm{mol}, 1.024 \mathrm{~g} / \mathrm{mL}, 8.79 \mathrm{~mL}[2 \times 4.395\right.$

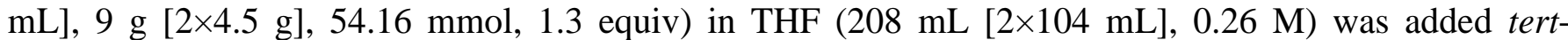
butyllithium $\left(\mathrm{C}_{4} \mathrm{H}_{9} \mathrm{Li}, 1.9 \mathrm{M}\right.$ in $n$-pentane, $26.32 \mathrm{~mL}$ [2×13.16 mL], $50.01 \mathrm{mmol}, 1.2$ equiv) at $-78{ }^{\circ} \mathrm{C}$ to afford two slightly yellow solutions. After being stirred for $1 \mathrm{~h}$ at $-78{ }^{\circ} \mathrm{C}$, a diastereomeric mixture $(\mathrm{dr}=$ 82:18) of the aldehyde (-)-5 $\left(\mathrm{C}_{15} \mathrm{H}_{27} \mathrm{ClO}_{5}, 322.83 \mathrm{~g} / \mathrm{mol}, 13.44 \mathrm{~g}\right.$ [2×6.72 g], $41.63 \mathrm{mmol}, 1$ equiv $)$ in THF $\left(418 \mathrm{~mL}\right.$ [2×209 mL], $0.1 \mathrm{M}$; overall: $0.067 \mathrm{M}$ in THF) was added dropwise at $-78{ }^{\circ} \mathrm{C}$ to both solutions to afford two slightly yellow solutions. After being stirred for $20 \mathrm{~min}$ at $-78{ }^{\circ} \mathrm{C}$, the resulting two slightly yellow solutions were diluted by the slow addition of saturated aqueous $\mathrm{NH}_{4} \mathrm{Cl}$ solution at $78{ }^{\circ} \mathrm{C}$. The cooling baths were removed, and the two slightly yellow biphasic mixtures were allowed to warm to ambient temperature. The resulting two yellow biphasic mixtures were transferred into a single separatory funnel using $\mathrm{CH}_{2} \mathrm{Cl}_{2}$ for rinsing. The phases were separated, and the aqueous layer was extracted with $\mathrm{CH}_{2} \mathrm{Cl}_{2}(8 \times)$. The combined organic layers were dried $\left(\mathrm{MgSO}_{4}\right)$. Removal of all volatiles under reduced pressure and attempted purification of the slightly yellow oil by flash chromatography (cyclohexane-ethyl acetate, 5:1 to 0:1) delivered a colorless oil (22.62 g). NMR analysis revealed significant but inseparable impurities, and the colorless oil was used without further purification.

The colorless oil (22.62 g) was dissolved in $\mathrm{CH}_{2} \mathrm{Cl}_{2}(278 \mathrm{~mL})$. To each of two colorless solutions of oxalyl chloride $\left(\mathrm{C}_{2} \mathrm{Cl}_{2} \mathrm{O}_{2}, 126.92 \mathrm{~g} / \mathrm{mol}, 1.5 \mathrm{~g} / \mathrm{mL}, 7.76 \mathrm{~mL}[2 \times 3.88 \mathrm{~mL}], 11.64 \mathrm{~g}\right.$ [2×5.82 g], 91.71 $\mathrm{mmol})$ in $\mathrm{CH}_{2} \mathrm{Cl}_{2}(417 \mathrm{~mL}$ [ $\left.2 \times 208.5 \mathrm{~mL}], 0.22 \mathrm{M}\right)$ at $-78{ }^{\circ} \mathrm{C}$ were added mixtures of dimethyl sulfoxide (DMSO, $\mathrm{C}_{2} \mathrm{H}_{6} \mathrm{OS}, 78.13 \mathrm{~g} / \mathrm{mol}, 1.1 \mathrm{~g} / \mathrm{mL}, 13.04 \mathrm{~mL}$ [2×6.52 mL], $14.34 \mathrm{~g}$ [2×7.17 g], $183.54 \mathrm{mmol}$ ) in $\mathrm{CH}_{2} \mathrm{Cl}_{2}(139 \mathrm{~mL}$ [ $\left.2 \times 69.5 \mathrm{~mL}], 1.32 \mathrm{M}\right)$ over a period of $5 \mathrm{~min}$ to afford two yellow solutions. After being stirred for $5 \mathrm{~min}$ at $-78{ }^{\circ} \mathrm{C}$, one half $(139 \mathrm{~mL})$ of the solution of the colorless oil in $\mathrm{CH}_{2} \mathrm{Cl}_{2}$ was added dropwise to each of the two yellow solutions at $-78{ }^{\circ} \mathrm{C}$ to afford two yellow reaction mixtures. After being stirred for $20 \mathrm{~min}$ at $-78{ }^{\circ} \mathrm{C}$, triethylamine $\left(\mathrm{Et}_{3} \mathrm{~N}, 101.19 \mathrm{~g} / \mathrm{mol}, 0.726 \mathrm{~g} / \mathrm{mL}, 58.1 \mathrm{~mL}[2 \times 29.05\right.$ $\mathrm{mL}$ ], $42.18 \mathrm{~g}$ [ $2 \times 21.09 \mathrm{~g}$ ], $416.84 \mathrm{mmol}$ ) was added over a period of $5 \mathrm{~min}$ at $-78{ }^{\circ} \mathrm{C}$ to both solutions to afford two yellow cloudy solutions. After being stirred for $5 \mathrm{~min}$ at $-78{ }^{\circ} \mathrm{C}$, the cooling baths were removed, and stirring was continued at ambient temperature. After being stirred for $2.5 \mathrm{~h}$ at ambient temperature, the resulting two yellow solutions were diluted by the slow addition of saturated aqueous $\mathrm{NH}_{4} \mathrm{Cl}$ solution at ambient temperature. The resulting two yellow biphasic mixtures were transferred into a single separatory funnel using $\mathrm{CH}_{2} \mathrm{Cl}_{2}$ for rinsing. The phases were separated, and the aqueous layer was extracted with $\mathrm{CH}_{2} \mathrm{Cl}_{2}(8 \times)$. The combined organic layers were dried $\left(\mathrm{MgSO}_{4}\right)$. Removal of all volatiles under reduced pressure and attempted purification of the yellow oil by flash chromatography (cyclohexane-ethyl acetate, 10:1 to 0:1) delivered a yellow oil (19.53 g). NMR analysis revealed significant but inseparable impurities, and the colorless oil was used without further purification.

To each of the two yellow solutions of the yellow oil $(19.53 \mathrm{~g}[2 \times 9.765 \mathrm{~g}])$ in THF $(514 \mathrm{~mL}$ [ $2 \times 257 \mathrm{~mL}])$ and water $(16 \mathrm{~mL}[2 \times 8 \mathrm{~mL}])$ was added barium hydroxide octahydrate $\left(\mathrm{BaH}_{18} \mathrm{O}_{10}, 315.46 \mathrm{~g} / \mathrm{mol}, 12.02 \mathrm{~g}\right.$ $[2 \times 6.01 \mathrm{~g}], 38.1 \mathrm{mmol})$ at ambient temperature to afford two yellow suspensions. After being stirred for 1 $\mathrm{h}$ at ambient temperature, the volatile aldehyde $(-)-6\left(\mathrm{C}_{6} \mathrm{H}_{10} \mathrm{O}, 33 \% \mathrm{~m} / \mathrm{m}\right.$ in $\mathrm{CH}_{2} \mathrm{Cl}_{2}, 5.96 \mathrm{~g}$ [2×2.98 g] containing $1.97 \mathrm{~g}$ [2×0.985 g] (-)-6, $98.15 \mathrm{~g} / \mathrm{mol}, 20.07 \mathrm{mmol})$ in THF (128 mL [2×64 mL], $0.77 \mathrm{M})$ was added to both suspensions to afford two yellow suspensions. After being stirred at ambient temperature for $4 \mathrm{~d}$, the resulting yellow reaction mixture were diluted at ambient temperature by the addition of saturated aqueous $\mathrm{NH}_{4} \mathrm{Cl}$ solution and diethyl ether $(v / v=3: 1)$. The resulting two yellow biphasic mixtures were transferred into a single separatory funnel using diethyl ether for rinsing. The phases were separated, and the aqueous layer was extracted with $\mathrm{CH}_{2} \mathrm{Cl}_{2}(8 \times)$. The combined organic layers were dried $\left(\mathrm{MgSO}_{4}\right)$. Removal of all volatiles under reduced pressure delivered a yellow oil. Purification of the yellow oil by flash chromatography (cyclohexane-ethyl acetate, 50:1 to 0:1 and $\mathrm{CH}_{2} \mathrm{Cl}_{2}-$ methanol, $250: 1$ to 50:1) afforded a yellow oil (8.21 g) and an inseparable mixture of diastereomers of $(-)-7\left(\mathrm{C}_{23} \mathrm{H}_{39} \mathrm{ClO}_{5}\right.$, $431.01 \mathrm{~g} / \mathrm{mol}, 3.7 \mathrm{~g}, 8.58 \mathrm{mmol}, 21 \%, \mathrm{dr}=82: 18$ according to NMR evaluation) as a colorless oil. Note: Subjecting the recovered yellow oil to the analogous conditions two more times led to the isolation of additional (-)-7 (overall: $5.28 \mathrm{~g}, 12.25 \mathrm{mmol}, 29 \%$ ). The ratio of diastereomers was determined by integration of the ${ }^{1} \mathrm{H}$ NMR signals at $3.75 \mathrm{ppm}$ (minor) and $3.80 \mathrm{ppm}$ (major). The configuration of the 18- $\mathrm{CH} / 19-\mathrm{C}$ double bond was tentatively assigned and later confirmed by the interpretation of a NOE experiment. $\mathrm{R}_{\mathrm{f}} 0.6$ (cyclohexane-ethyl acetate, $\left.2: 1\right) ;[\alpha]_{\mathrm{D}}{ }^{20}=-52.7\left(c=1, \mathrm{CHCl}_{3}\right)$; NMR data are reported 
for the major diastereomer: ${ }^{1} \mathrm{H}$ NMR $\left(\mathrm{CDCl}_{3}, 600 \mathrm{MHz}\right) \delta 0.97-1.00(\mathrm{~m}, 6 \mathrm{H}), 1.05-1.07(\mathrm{~m}, 3 \mathrm{H}), 1.38(\mathrm{~s}$, $3 \mathrm{H}), 1.47(\mathrm{~s}, 3 \mathrm{H}), 1.59$ (ddd, $J=14.3,11.8,3.6 \mathrm{~Hz}, 1 \mathrm{H}), 1.79(\mathrm{~d}, J=1.3 \mathrm{~Hz}, 3 \mathrm{H}), 1.94(\mathrm{ddd}, J=14.2$, 10.6, $2.6 \mathrm{~Hz}, 1 \mathrm{H}), 2.10-2.20(\mathrm{~m}, 3 \mathrm{H}), 2.68$ (apparent dq, $J=9.4,6.9 \mathrm{~Hz}, 1 \mathrm{H}), 3.25(\mathrm{~s}, 3 \mathrm{H}), 3.52$ (apparent $\mathrm{dq}, J=9.5,7.0 \mathrm{~Hz}, 1 \mathrm{H}), 3.80(\mathrm{dd}, J=9.5,1.1 \mathrm{~Hz}, 1 \mathrm{H}), 3.92(\mathrm{dd}, J=8.5,6.6 \mathrm{~Hz}, 1 \mathrm{H}), 4.06(\mathrm{dd}, J=8.5$, $6.6 \mathrm{~Hz}, 1 \mathrm{H}), 4.10(\mathrm{ddd}, J=11.8,5.1,2.6 \mathrm{~Hz}, 1 \mathrm{H}), 4.22$ (apparent td, $J=6.6,5.1 \mathrm{~Hz}, 1 \mathrm{H}), 4.35(\mathrm{~d}, J=6.7$ $\mathrm{Hz}, 1 \mathrm{H}), 4.51(\mathrm{~d}, J=6.7 \mathrm{~Hz}, 1 \mathrm{H}), 4.99-5.06(\mathrm{~m}, 2 \mathrm{H}), 5.72$ (apparent ddt, $J=17.1,10.1,7.1 \mathrm{~Hz}, 1 \mathrm{H}), 6.41$ $(\mathrm{dd}, J=9.5,1.2 \mathrm{~Hz}, 1 \mathrm{H}) ;{ }^{13} \mathrm{C} \mathrm{NMR}\left(\mathrm{CDCl}_{3}, 151 \mathrm{MHz}\right) \delta 12.1\left(\mathrm{CH}_{3}\right), 14.5\left(\mathrm{CH}_{3}\right), 15.6\left(\mathrm{CH}_{3}\right), 19.7\left(\mathrm{CH}_{3}\right)$, $25.5\left(\mathrm{CH}_{3}\right), 26.4\left(\mathrm{CH}_{3}\right), 30.7(\mathrm{CH}), 33.7(\mathrm{CH}), 37.3\left(\mathrm{CH}_{2}\right), 41.2\left(\mathrm{CH}_{2}\right), 42.5(\mathrm{CH}), 55.7\left(\mathrm{CH}_{3}\right), 60.9(\mathrm{CH})$, $66.6\left(\mathrm{CH}_{2}\right), 79.2(\mathrm{CH}), 82.1(\mathrm{CH}), 98.9\left(\mathrm{CH}_{2}\right), 110.0(\mathrm{C}), 116.6\left(\mathrm{CH}_{2}\right), 136.0(\mathrm{C}), 136.2(\mathrm{CH}), 147.7$ (CH), $205.3(\mathrm{C}) ;$ IR $\vee 2970(\mathrm{w}), 1665(\mathrm{~m}), 1640(\mathrm{w}), 1455(\mathrm{w}), 1370(\mathrm{~m}), 1260(\mathrm{w}), 1215(\mathrm{~m}), 1155(\mathrm{~m})$, 1030 (s), 965 (w), 915 (m), 855 (m), 795 (w), 740 (w), 685 (w), 555 (w), 510 (w), 425 (w); Anal. Calcd. for $\mathrm{C}_{23} \mathrm{H}_{39} \mathrm{ClO}_{5}$ : C, 64.1; $\mathrm{H}, 9.1$; Found: $\mathrm{C}, 63.9 ; \mathrm{H}, 9.1$.

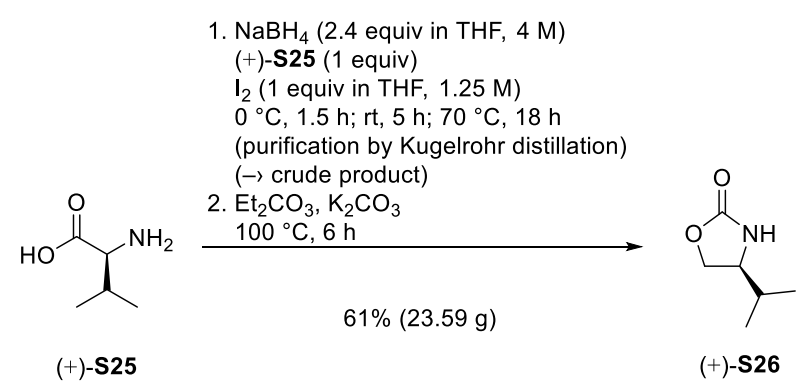

Oxazolidinone (+)-S26. ${ }^{10,11}$ Note: Slightly modified and optimized procedure. To a stirred solution of sodium borohydride $\left(\mathrm{NaBH}_{4}, 37.83 \mathrm{~g} / \mathrm{mol}, 27.13 \mathrm{~g}, 717.16 \mathrm{mmol}, 2.4\right.$ equiv) in THF $(179 \mathrm{~mL}, 4 \mathrm{M})$ at 0 ${ }^{\circ} \mathrm{C}$ was added $L-(+)$-valine $\mathbf{S 2 5}\left(\mathrm{C}_{5} \mathrm{H}_{11} \mathrm{NO}_{2}, 117.15 \mathrm{~g} / \mathrm{mol}, 35 \mathrm{~g}, 298.76 \mathrm{mmol}, 1\right.$ equiv) in one portion to afford a white suspension. After being stirred for $5 \mathrm{~min}$ at $0{ }^{\circ} \mathrm{C}$, a purple solution of iodine $\left(\mathrm{I}_{2}, 253.81\right.$ $\mathrm{g} / \mathrm{mol}, 75.83 \mathrm{~g}, 298.77 \mathrm{mmol}, 1$ equiv) in THF (239 mL, 1.25 M) (overall: $0.71 \mathrm{M}$ in valine in THF) was added dropwise over a period of $1.5 \mathrm{~h}$ at $0{ }^{\circ} \mathrm{C}$ to afford a white suspension. After being stirred for $5 \mathrm{~h}$ at ambient temperature, the white suspension was placed in a pre-heated oil bath $\left(70{ }^{\circ} \mathrm{C}\right)$, and stirring was continued for $18 \mathrm{~h}$. The resulting white suspension was cooled to ambient temperature and was slowly diluted by the addition of $\mathrm{MeOH}$ until a clear solution was obtained. Removal of all volatiles under reduced pressure afforded a white paste which was diluted by the addition of $\mathrm{KOH}(20 \% \mathrm{~m} / \mathrm{m}$ in water, $269 \mathrm{~mL}$ ). The resulting clear solution was stirred for $16.5 \mathrm{~h}$ at ambient temperature and was subsequently diluted by the addition of $\mathrm{CH}_{2} \mathrm{Cl}_{2}$. The resulting biphasic mixture was transferred into a separatory funnel using $\mathrm{CH}_{2} \mathrm{Cl}_{2}$ for rinsing. The phases were separated, and the aqueous layer was extracted with $\mathrm{CH}_{2} \mathrm{Cl}_{2}$ $(5 \times)$. The combined organic layers were dried $\left(\mathrm{MgSO}_{4}\right)$. Removal of all volatiles under reduced pressure and subsequent Kugelrohr distillation $\left(85^{\circ} \mathrm{C}, 0.8 \mathrm{mbar}\right)$ of the clear oil delivered a white solid $(24.5 \mathrm{~g})$, presumably $L-(+)$-valinol, which was used without proof of structure or of purity.

To a solution of the white solid $(24.5 \mathrm{~g})$ in diethyl carbonate $\left(\mathrm{Et}_{2} \mathrm{CO}_{3}, 118.13 \mathrm{~g} / \mathrm{mol}, 0.975 \mathrm{~g} / \mathrm{mL}, 29.74\right.$ $\mathrm{mL}, 29 \mathrm{~g}, 245.49 \mathrm{mmol})$ was added potassium carbonate $\left(\mathrm{K}_{2} \mathrm{CO}_{3}, 138.2 \mathrm{~g} / \mathrm{mol}, 3.28 \mathrm{~g}, 23.73 \mathrm{mmol}\right)$ to afford a white suspension. The suspension was placed in a pre-heated oil bath $\left(100^{\circ} \mathrm{C}\right)$. Ethanol was removed by distillation as it was formed. After being stirred for $6 \mathrm{~h}$ at $100{ }^{\circ} \mathrm{C}{ }^{\circ} \mathrm{C}$, the white suspension was cooled to ambient temperature and was diluted by the addition of diethyl ether. Filtration through Celite ${ }^{\circledR}$ and subsequent rinsing with diethyl ether (6x) afforded a clear solution. Removal of all volatiles under reduced pressure and subsequent purification of the clear oil by flash chromatography (cyclohexane-ethyl acetate, 20:1 to 2:1) delivered (+)-S26 $\left(\mathrm{C}_{6} \mathrm{H}_{11} \mathrm{NO}_{2}, 129.16 \mathrm{~g} / \mathrm{mol}, 23.59 \mathrm{~g}, 182.64\right.$ mmol, $61 \%$ ) as a white solid. $\mathrm{R}_{\mathrm{f}} 0.49$ (ethyl acetate); m.p. $72.3{ }^{\circ} \mathrm{C} ;[\alpha]_{\mathrm{D}}{ }^{20}=+7.5\left(c=1, \mathrm{CHCl}_{3}\right) ;{ }^{1} \mathrm{H}$ NMR $\left(\mathrm{CDCl}_{3}, 400 \mathrm{MHz}\right) \delta 0.89(\mathrm{~d}, J=6.8 \mathrm{~Hz}, 3 \mathrm{H}), 0.95(\mathrm{~d}, J=6.7 \mathrm{~Hz}, 3 \mathrm{H}), 1.72$ (apparent dsxt, $J=13.5,6.8$ $\mathrm{Hz}, 1 \mathrm{H}), 3.60$ (apparent dt, $J=8.1,6.8 \mathrm{~Hz}, 1 \mathrm{H}), 4.09(\mathrm{dd}, J=8.6,6.4 \mathrm{~Hz} 1 \mathrm{H}), 4.43$ (apparent t, $J=8.7$ $\mathrm{Hz}, 1 \mathrm{H}), 6.67$ (br. s, $1 \mathrm{H}) ;{ }^{13} \mathrm{C} \mathrm{NMR}\left(\mathrm{CDCl}_{3}, 101 \mathrm{MHz}\right) \delta 17.8\left(\mathrm{CH}_{3}\right), 18.1\left(\mathrm{CH}_{3}\right), 32.8(\mathrm{CH}), 58.5(\mathrm{CH})$, $68.7\left(\mathrm{CH}_{2}\right), 160.6(\mathrm{C})$; IR v $3260(\mathrm{~m}), 2960(\mathrm{w}), 1720$ (s), $1470(\mathrm{w}), 1405(\mathrm{~m}), 1385(\mathrm{~m}), 1360(\mathrm{w}), 1325$ (w), $1245(\mathrm{~s}), 1180(\mathrm{w}), 1135(\mathrm{w}), 1090(\mathrm{~m}), 1050(\mathrm{~m}), 1010(\mathrm{~s}), 980(\mathrm{w}), 935(\mathrm{~s}), 900(\mathrm{w}), 770(\mathrm{~m}), 680$ 
(m), $550(\mathrm{w}), 460(\mathrm{w}), 415(\mathrm{w}) \mathrm{cm}^{-1}$. Our analytical data are in accordance to those reported in the literature.

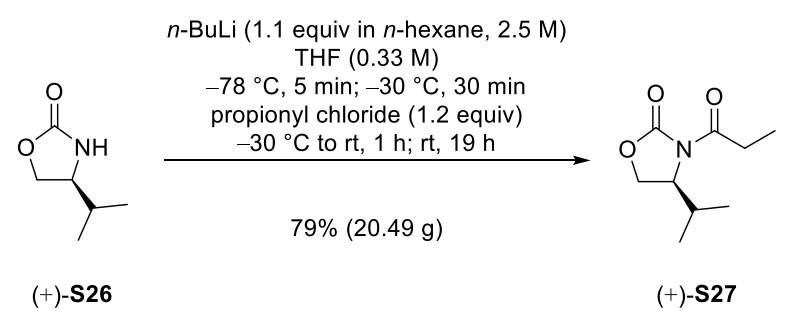

$N$-Propionyl Oxazolidinone (+)-S27. ${ }^{14}$ Note: Slightly modified and optimized procedure. To a stirred solution of the oxazolidinone (+)-S26 $\left(\mathrm{C}_{6} \mathrm{H}_{11} \mathrm{NO}_{2}, 129.16 \mathrm{~g} / \mathrm{mol}, 18.06 \mathrm{~g}, 139.83 \mathrm{mmol}, 1 \mathrm{equiv}\right)$ in THF $(419 \mathrm{~mL}, 0.33 \mathrm{M})$ at $-78{ }^{\circ} \mathrm{C}$ was added $n$-butyllithium $\left(\mathrm{C}_{4} \mathrm{H}_{9} \mathrm{Li}, 2.5 \mathrm{M}\right.$ in $n$-hexane, $61.52 \mathrm{~mL}, 153.8$ mmol, 1.1 equiv) to afford a slightly yellow solution. After being stirred for $5 \mathrm{~min}$ at $-78{ }^{\circ} \mathrm{C}$, the solution was warmed to $-30{ }^{\circ} \mathrm{C}$ and stirring was continued at $-30{ }^{\circ} \mathrm{C}$ for $30 \mathrm{~min}$. Freshly distilled $\left(90{ }^{\circ} \mathrm{C}\right)$ propionyl chloride $\left(\mathrm{C}_{3} \mathrm{H}_{5} \mathrm{ClO}, 92.52 \mathrm{~g} / \mathrm{mol}, 1.06 \mathrm{~g} / \mathrm{mL}, 14.64 \mathrm{~mL}, 15.52 \mathrm{~g}, 167.75 \mathrm{mmol}, 1.2\right.$ equiv) was added at $-30{ }^{\circ} \mathrm{C}$ to afford a slightly yellow solution. The slightly yellow reaction mixture was allowed warming to ambient temperature over a period of $1 \mathrm{~h}$. After being stirred for $19 \mathrm{~h}$ at ambient temperature, the yellow reaction mixture was diluted by the slow addition of saturated aqueous $\mathrm{NH}_{4} \mathrm{Cl}$ solution at ambient temperature. The resulting biphasic mixture was transferred into a separatory funnel using diethyl ether for rinsing. The phases were separated, and the aqueous layer was extracted with $\mathrm{CH}_{2} \mathrm{Cl}_{2}(5 \times)$. The combined organic layers were dried $\left(\mathrm{MgSO}_{4}\right)$. Removal of all volatiles under reduced pressure and subsequent purification of the yellow oil by flash chromatography (cyclohexane-ethyl acetate, 100:1 to 5:1) delivered (+)-S27 $\left(\mathrm{C}_{9} \mathrm{H}_{15} \mathrm{NO}_{3}, 185.22 \mathrm{~g} / \mathrm{mol}, 20.49 \mathrm{~g}, 110.63 \mathrm{mmol}, 79 \%\right)$ as a clear colorless oil. $\mathrm{R}_{\mathrm{f}}$ 0.29 (cyclohexane-ethyl acetate, $5: 1) ;[\alpha]_{\mathrm{D}}{ }^{20}=+97.9\left(c=1, \mathrm{CHCl}_{3}\right) ;{ }^{1} \mathrm{H} \mathrm{NMR}\left(\mathrm{CDCl}_{3}, 400 \mathrm{MHz}\right) \delta 0.89$ $(\mathrm{d}, J=6.9 \mathrm{~Hz}, 3 \mathrm{H}), 0.92(\mathrm{~d}, J=7.1 \mathrm{~Hz}, 3 \mathrm{H}), 1.17(\mathrm{t}, J=7.4 \mathrm{~Hz}, 3 \mathrm{H}), 1.72$ (apparent dquind, $J=14.0,7.0$, $3.9 \mathrm{~Hz}, 1 \mathrm{H}), 2.85-3.04(\mathrm{~m}, 2 \mathrm{H}), 4.18-4.30(\mathrm{~m}, 2 \mathrm{H}), 4.43$ (apparent dt, $J=8.3,3.5 \mathrm{~Hz}, 1 \mathrm{H}) ;{ }^{13} \mathrm{C} \mathrm{NMR}$ $\left(\mathrm{CDCl}_{3}, 101 \mathrm{MHz}\right) \delta 8.6\left(\mathrm{CH}_{3}\right), 14.8\left(\mathrm{CH}_{3}\right), 18.1\left(\mathrm{CH}_{3}\right), 28.5(\mathrm{CH}), 29.3\left(\mathrm{CH}_{2}\right), 58.6(\mathrm{CH}), 63.5\left(\mathrm{CH}_{2}\right)$, $154.3(\mathrm{C}), 174.2$ (C); IR v 2965 (w), 2880 (w), 1775 (s), 1700 (s), 1485 (w), 1460 (w), 1375 (s), 1300 (m), $1245(\mathrm{~m}), 1205$ (s), $1145(\mathrm{~m}), 1120(\mathrm{~m}), 1070(\mathrm{~m}), 1025(\mathrm{~m}), 985(\mathrm{~m}), 945(\mathrm{~m}), 895(\mathrm{w}), 805(\mathrm{w}), 775$ $(\mathrm{m}), 760(\mathrm{~m}), 700(\mathrm{~m}), 600(\mathrm{w}) \mathrm{cm}^{-1}$. Our analytical data are in accordance to those reported in the literature.

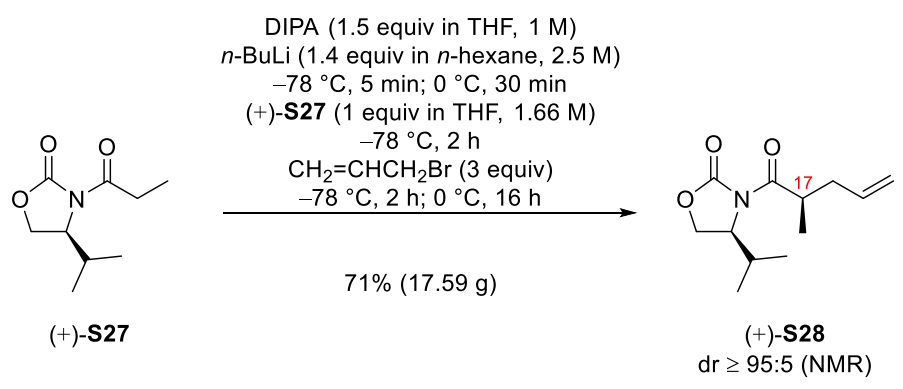

(S)-4-Isopropyl-3-((R)-2-methylpent-4-enoyl)oxazolidin-2-one (+)-S28. ${ }^{15}$ Note: Slightly modified and optimized procedure. To a stirred solution of diisopropylamine (DIPA, $\mathrm{C}_{6} \mathrm{H}_{15} \mathrm{~N}, 101.19 \mathrm{~g} / \mathrm{mol}, 0.722$ $\mathrm{g} / \mathrm{mL}, 23.14 \mathrm{~mL}, 16.71 \mathrm{~g}, 165.13 \mathrm{mmol}, 1.5$ equiv) in THF $(164 \mathrm{~mL}, 1 \mathrm{M})$ at $-78{ }^{\circ} \mathrm{C}$ was added $n$ butyllithium $\left(\mathrm{C}_{4} \mathrm{H}_{9} \mathrm{Li}, 2.5 \mathrm{M}\right.$ in $n$-hexane, $61.46 \mathrm{~mL}, 153.65 \mathrm{mmol}, 1.4$ equiv) to afford a colorless solution. After being stirred for $5 \mathrm{~min}$ at $-78{ }^{\circ} \mathrm{C}$, the solution was warmed to $0{ }^{\circ} \mathrm{C}$ and stirring was continued at $0{ }^{\circ} \mathrm{C}$ for $30 \mathrm{~min}$. A solution of $N$-propionyl oxazolidinone (+)-S27 $\left(\mathrm{C}_{9} \mathrm{H}_{15} \mathrm{NO}_{3}, 185.22 \mathrm{~g} / \mathrm{mol}\right.$, $20.33 \mathrm{~g}, 109.76 \mathrm{mmol}, 1$ equiv) in THF (66 mL, $1.66 \mathrm{M}$; overall: $0.48 \mathrm{M}$ in THF) was added at $-78^{\circ} \mathrm{C}$ to afford a slightly yellow solution. After being stirred for $2 \mathrm{~h}$ at $-78{ }^{\circ} \mathrm{C}$, allyl bromide $\left(\mathrm{C}_{3} \mathrm{H}_{5} \mathrm{Br}, 120.98\right.$ $\mathrm{g} / \mathrm{mol}, 1.398 \mathrm{~g} / \mathrm{mL}, 28.45 \mathrm{~mL}, 39.77 \mathrm{~g}, 328.76 \mathrm{mmol}, 3$ equiv) was added at $-78{ }^{\circ} \mathrm{C}$ to afford a yellow reaction mixture. After being stirred for $2 \mathrm{~h}$ at $-78{ }^{\circ} \mathrm{C}$ and subsequently $16 \mathrm{~h}$ at $0{ }^{\circ} \mathrm{C}$, the yellow reaction 
mixture was diluted by the slow addition of saturated aqueous $\mathrm{NH}_{4} \mathrm{Cl}$ solution at $0{ }^{\circ} \mathrm{C}$. The resulting biphasic mixture was transferred into a separatory funnel using diethyl ether for rinsing. The phases were separated, and the aqueous layer was extracted with $\mathrm{CH}_{2} \mathrm{Cl}_{2}(4 \times)$. The combined organic layers were dried $\left(\mathrm{MgSO}_{4}\right)$. Removal of all volatiles under reduced pressure and subsequent purification of the yellow oil by flash chromatography (cyclohexane-ethyl acetate, 100:1 to 2:1) delivered (+)-S28 $\left(\mathrm{C}_{12} \mathrm{H}_{19} \mathrm{NO}_{3}, 225.29\right.$ $\mathrm{g} / \mathrm{mol}, 17.59 \mathrm{~g}, 78.08 \mathrm{mmol}, 71 \%, \mathrm{dr} \geq 95: 5$ according to NMR evaluation) as a yellow oil. The absolute configuration of 17- $\mathrm{CH}$ was assigned in accordance with the accepted stereochemical model for the asymmetric induction by the chiral auxiliary. $\mathrm{R}_{\mathrm{f}} 0.29$ (cyclohexane-ethyl acetate, $\left.5: 1\right) ;[\alpha]_{\mathrm{D}}{ }^{20}=+62.6(c=$ $\left.1, \mathrm{CHCl}_{3}\right) ;{ }^{1} \mathrm{H} \mathrm{NMR}\left(\mathrm{CDCl}_{3}, 500 \mathrm{MHz}\right) \delta 0.86(\mathrm{~d}, J=6.9 \mathrm{~Hz}, 3 \mathrm{H}), 0.90(\mathrm{~d}, J=7.1 \mathrm{~Hz}, 3 \mathrm{H}), 1.14(\mathrm{~d}, J=$ $6.8 \mathrm{~Hz}, 3 \mathrm{H}$ ), 2.20 (apparent dt, $J=13.9,7.0 \mathrm{~Hz}, 1 \mathrm{H}$ ), 2.32 (apparent dquind, $J=14.0,7.0,3.8 \mathrm{~Hz}, 1 \mathrm{H}$ ), 2.50 (apparent dt, $J=13.8,6.8 \mathrm{~Hz}, 1 \mathrm{H}$ ), 3.88 (apparent sxt, $J=6.8 \mathrm{~Hz}, 1 \mathrm{H}$ ), 4.20 (dd, $J=9.1,3.0 \mathrm{~Hz}$, $1 \mathrm{H}), 4.26$ (apparent t, $J=8.6 \mathrm{~Hz}, 1 \mathrm{H}), 4.45$ (apparent dt, $J=8.4,3.4 \mathrm{~Hz}, 1 \mathrm{H}), 5.03$ (apparent dt, $J=10.1$, $0.9 \mathrm{~Hz}, 1 \mathrm{H}), 5.04-5.09(\mathrm{~m}, 1 \mathrm{H}), 5.79$ (apparent ddt, $J=17.1,10.1,7.0 \mathrm{~Hz}, 1 \mathrm{H}) ;{ }^{13} \mathrm{C} \mathrm{NMR}\left(\mathrm{CDCl}_{3}, 126\right.$ MHz) $\delta 14.8\left(\mathrm{CH}_{3}\right), 16.4\left(\mathrm{CH}_{3}\right), 18.1\left(\mathrm{CH}_{3}\right), 28.5(\mathrm{CH}), 37.3(\mathrm{CH}), 38.4\left(\mathrm{CH}_{2}\right), 58.6(\mathrm{CH}), 63.2\left(\mathrm{CH}_{2}\right)$, $117.3\left(\mathrm{CH}_{2}\right), 135.4(\mathrm{CH}), 153.9(\mathrm{C}), 176.6(\mathrm{C})$; IR $\vee 2970(\mathrm{w}), 2930(\mathrm{w}), 1770(\mathrm{~s}), 1695(\mathrm{~s}), 1640(\mathrm{w})$, 1485 (w), 1455 (w), 1385 (s), 1300 (m), 1240 (m), 1200 (s), 1140 (w), 1120 (m), 1090 (s), 1055 (m), 1015 (w), $990(\mathrm{~s}), 965(\mathrm{~m}), 915(\mathrm{~m}), 775(\mathrm{w}), 745(\mathrm{w}), 705(\mathrm{w}), 690(\mathrm{w}), 645(\mathrm{w}), 460(\mathrm{w}) \mathrm{cm}^{-1}$. Our analytical data are in accordance to those reported in the literature.

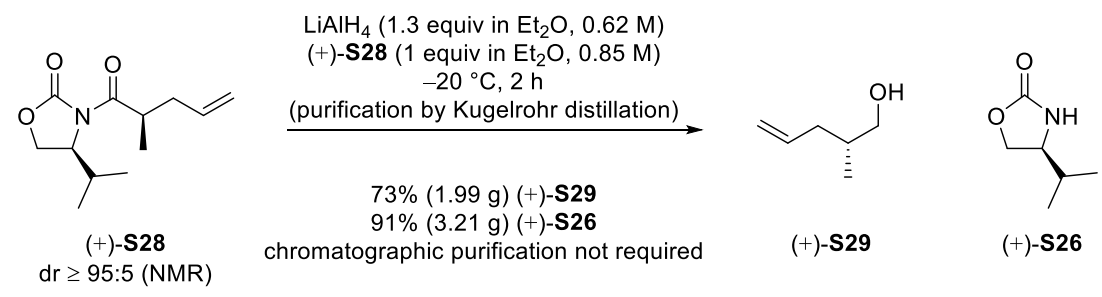

Alcohol (+)-S29. ${ }^{16}$ Note: Slightly modified and optimized procedure. To a stirred grey suspension of lithium aluminum hydride $\left(\mathrm{LiAlH}_{4}, 37.95 \mathrm{~g} / \mathrm{mol}, 1.35 \mathrm{~g}, 35.57 \mathrm{mmol}, 1.3 \mathrm{equiv}\right)$ in diethyl ether $(57 \mathrm{~mL}$, $0.62 \mathrm{M})$ at $-20{ }^{\circ} \mathrm{C}$ was added a solution of $(S)$-4-isopropyl-3-((R)-2-methylpent-4-enoyl)oxazolidin-2-one (+)-S28 $\left(\mathrm{C}_{12} \mathrm{H}_{19} \mathrm{NO}_{3}, 225.29 \mathrm{~g} / \mathrm{mol}, 6.16 \mathrm{~g}, 27.34 \mathrm{mmol}, 1\right.$ equiv) in diethyl ether $(32 \mathrm{~mL}, 0.85 \mathrm{M}$; overall: $0.31 \mathrm{M}$ in diethyl ether) to afford a slightly yellow grey suspension. After being stirred for $2 \mathrm{~h}$ at $20{ }^{\circ} \mathrm{C}$, the slightly yellow grey suspension was diluted by the slow addition of saturated aqueous potassium sodium tartrate solution at $-20{ }^{\circ} \mathrm{C}$. The cooling bath was removed, and the colorless biphasic mixture was allowed to warm to ambient temperature. After being stirred for $5 \mathrm{~h}$ at ambient temperature, the resulting colorless biphasic mixture was transferred into a separatory funnel using diethyl ether for rinsing. The phases were separated, and the aqueous layer was extracted with diethyl ether (4x). The combined organic layers were dried $\left(\mathrm{MgSO}_{4}\right)$. Removal of all volatiles under reduced pressure $\left(40{ }^{\circ} \mathrm{C}\right.$, 600 mbar) and subsequent purification of the yellow oil by Kugelrohr distillation $\left(90{ }^{\circ} \mathrm{C}, 5 \mathrm{mbar}\right)$ delivered volatile (+)-S29 $\left(\mathrm{C}_{6} \mathrm{H}_{12} \mathrm{O}, 100.16 \mathrm{~g} / \mathrm{mol}, 1.99 \mathrm{~g}, 19.87 \mathrm{mmol}, 73 \%\right)$ as a colorless oil, and (+)S26 $\left(\mathrm{C}_{6} \mathrm{H}_{11} \mathrm{NO}_{2}, 129.16 \mathrm{~g} / \mathrm{mol}, 3.21 \mathrm{~g}, 24.85 \mathrm{mmol}, 91 \%\right.$ auxiliary recycling $)$ as a slightly yellow solid. $\mathrm{R}_{\mathrm{f}}$ 0.26 (cyclohexane-ethyl acetate, $5: 1) ;[\alpha]_{\mathrm{D}}{ }^{20}=+3.4\left(c=1, \mathrm{CHCl}_{3}\right) ;{ }^{1} \mathrm{H} \mathrm{NMR}\left(\mathrm{CDCl}_{3}, 500 \mathrm{MHz}\right) \delta 0.92$ $(\mathrm{d}, J=6.8 \mathrm{~Hz}, 3 \mathrm{H}), 1.35$ (br. s, $1 \mathrm{H}), 1.74$ (apparent dsxt, $J=13.3,6.6 \mathrm{~Hz}, 1 \mathrm{H}), 1.95$ (apparent dt, $J=14.1$, $7.2 \mathrm{~Hz}, 1 \mathrm{H}$ ), 2.17 (apparent dt, $J=13.7,6.6 \mathrm{~Hz}, 1 \mathrm{H}), 3.43-3.55(\mathrm{~m}, 2 \mathrm{H}), 4.99-5.08(\mathrm{~m}, 2 \mathrm{H}), 5.81$ (apparent ddt, $J=17.1,10.0,7.2 \mathrm{~Hz}, 1 \mathrm{H}) ;{ }^{13} \mathrm{C} \mathrm{NMR}\left(\mathrm{CDCl}_{3}, 126 \mathrm{MHz}\right) \delta 16.5\left(\mathrm{CH}_{3}\right), 35.7(\mathrm{CH}), 38.0$ $\left(\mathrm{CH}_{2}\right), 68.1\left(\mathrm{CH}_{2}\right), 116.3\left(\mathrm{CH}_{2}\right), 137.1(\mathrm{CH})$; IR $\vee 3330(\mathrm{~m}), 3075(\mathrm{w}), 2955(\mathrm{~m}), 2910(\mathrm{~m}), 2875(\mathrm{~m})$,

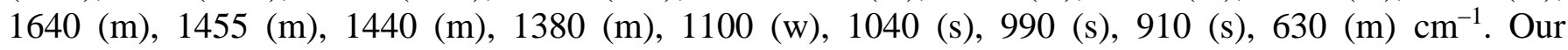
analytical data are in accordance to those reported in the literature. 


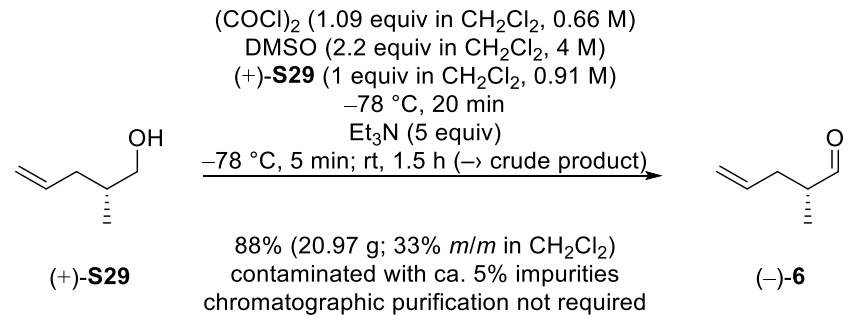

Aldehyde (-)-6. ${ }^{17}$ Note: The reaction was carried out in parallel in four batches and in accordance to the literature procedure. To each of the four colorless solutions of oxalyl chloride $\left(\mathrm{C}_{2} \mathrm{Cl}_{2} \mathrm{O}_{2}, 126.92 \mathrm{~g} / \mathrm{mol}\right.$, $1.5 \mathrm{~g} / \mathrm{mL}, 7.52 \mathrm{~mL}$ [ $4 \times 1.88 \mathrm{~mL}], 11.28 \mathrm{~g}$ [ $2 \times 2.82 \mathrm{~g}$ ], $86.82 \mathrm{mmol}, 1.09$ equiv $)$ in $\mathrm{CH}_{2} \mathrm{Cl}_{2}(132 \mathrm{~mL}$ [ $4 \times 33$ $\mathrm{mL}$ ], $0.66 \mathrm{M}$ ) at $-78{ }^{\circ} \mathrm{C}$ were added mixtures of dimethyl sulfoxide (DMSO, $\mathrm{C}_{2} \mathrm{H}_{6} \mathrm{OS}, 78.13 \mathrm{~g} / \mathrm{mol}, 1.1$ $\mathrm{g} / \mathrm{mL}, 12.48 \mathrm{~mL}$ [ $4 \times 3.12 \mathrm{~mL}], 13.72 \mathrm{~g}$ [4×3.43 g], $175.6 \mathrm{mmol}, 2.2$ equiv) in $\mathrm{CH}_{2} \mathrm{Cl}_{2}(44 \mathrm{~mL}$ [ $4 \times 11 \mathrm{~mL}]$, $4 \mathrm{M}$ ) over a period of $5 \mathrm{~min}$ to afford four white suspensions. After being stirred for $5 \mathrm{~min}$ at $-78{ }^{\circ} \mathrm{C}$, a mixture of the volatile alcohol (+)-S29 $\left(\mathrm{C}_{6} \mathrm{H}_{12} \mathrm{O}, 100.16 \mathrm{~g} / \mathrm{mol}, 8 \mathrm{~g}[4 \times 2 \mathrm{~g}], 79.87 \mathrm{mmol}, 1\right.$ equiv) in $\mathrm{CH}_{2} \mathrm{Cl}_{2}$ (88 $\mathrm{mL}$ [ $4 \times 22 \mathrm{~mL}$ ], $0.91 \mathrm{M}$; overall: $0.3 \mathrm{M}$ in $\mathrm{CH}_{2} \mathrm{Cl}_{2}$ ) was added dropwise to each of the white suspensions at $-78{ }^{\circ} \mathrm{C}$ to afford four white reaction mixtures. After being stirred for 20 min at $-78{ }^{\circ} \mathrm{C}$, triethylamine $\left(\mathrm{Et}_{3} \mathrm{~N}, 101.19 \mathrm{~g} / \mathrm{mol}, 0.726 \mathrm{~g} / \mathrm{mL}, 55.36 \mathrm{~mL}\right.$ [4×13.84 mL], $40.2 \mathrm{~g}$ [4×10.05 g], 397.27 mmol, 5 equiv) was added over a period of $5 \mathrm{~min}$ at $-78^{\circ} \mathrm{C}$ to afford four yellow white suspensions. After being stirred for $5 \mathrm{~min}$ at $-78{ }^{\circ} \mathrm{C}$, the cooling baths were removed, and stirring was continued at ambient temperature. After being stirred for $1.5 \mathrm{~h}$ at ambient temperature, the resulting four yellow white suspensions were diluted by the slow addition of water at $0{ }^{\circ} \mathrm{C}$. The resulting four yellow biphasic mixtures were transferred into a single separatory funnel using $\mathrm{CH}_{2} \mathrm{Cl}_{2}$ for rinsing and were washed successively with $1 \mathrm{M}$ aqueous $\mathrm{HCl}$ solution $(4 \times)$, saturated aqueous $\mathrm{NaHCO}_{3}$ solution, and saturated aqueous $\mathrm{NaCl}$ solution. The combined organic layer was dried $\left(\mathrm{MgSO}_{4}\right)$. Removal of volatiles under reduced pressure $\left(40{ }^{\circ} \mathrm{C}, 640 \mathrm{mbar}\right)$ to a final volume of $15 \mathrm{~mL}$ delivered a yellow solution $(20.97 \mathrm{~g}) .{ }^{1} \mathrm{H}$ NMR examination of an aliquot revealed that the yellow solution consisted of $\mathrm{CH}_{2} \mathrm{Cl}_{2}$ and volatile (-)-6 $\left(\mathrm{C}_{6} \mathrm{H}_{10} \mathrm{O}, 33 \% \mathrm{~m} / \mathrm{m}\right.$ in $\mathrm{CH}_{2} \mathrm{Cl}_{2}, 20.97 \mathrm{~g}$ containing $\left.6.92 \mathrm{~g}(-)-6,98.15 \mathrm{~g} / \mathrm{mol}, 70.5 \mathrm{mmol}, 88 \%\right)$ contaminated with NMR-visible but inseparable impurities (ca. $5 \% \mathrm{n} / \mathrm{n}$ ). The solution was used without further purification. $[\alpha]_{\mathrm{D}}{ }^{20}=-7.2\left(c=1, \mathrm{CHCl}_{3}\right) ;{ }^{1} \mathrm{H} \mathrm{NMR}\left(\mathrm{CDCl}_{3}, 400 \mathrm{MHz}\right) \delta 1.11(\mathrm{~d}, J=6.6 \mathrm{~Hz}, 3 \mathrm{H})$, 2.10-2.20 (m, 1H), 2.39-2.52 (m, 2H), 5.04-5.12 (m, 2H), $5.30\left(\mathrm{~s}, \mathrm{CH}_{2} \mathrm{Cl}_{2}\right), 5.75-5.82(\mathrm{~m}, 1 \mathrm{H}), 9.66$ (apparent s, $1 \mathrm{H}) ;{ }^{13} \mathrm{C} \mathrm{NMR}\left(\mathrm{CDCl}_{3}, 151 \mathrm{MHz}\right) \delta 13.2\left(\mathrm{CH}_{3}\right), 34.9\left(\mathrm{CH}_{2}\right), 46.0(\mathrm{CH}), 53.6\left(\mathrm{CH}_{2} \mathrm{Cl}_{2}\right), 117.4$ $\left(\mathrm{CH}_{2}\right), 135.1(\mathrm{CH}), 204.8(\mathrm{C})$; IR $\vee 2965(\mathrm{~m}), 2930(\mathrm{~m}), 2875(\mathrm{~m}), 2605(\mathrm{w}), 2500(\mathrm{w}), 1725(\mathrm{~s}), 1640$ (m), $1440(\mathrm{~m}), 1395(\mathrm{~m}), 1245(\mathrm{~m}), 1160(\mathrm{~m}), 1035(\mathrm{~m}), 995(\mathrm{~m}), 915(\mathrm{~s}), 875(\mathrm{~m}), 810(\mathrm{~m}), 765(\mathrm{~m}), 710$ (m), $470(\mathrm{w}) \mathrm{cm}^{-1}$. Our analytical data matched those reported in the literature.

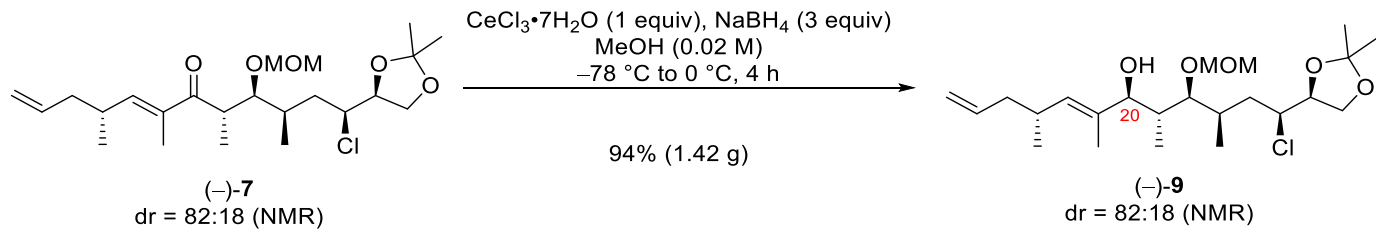

Allyl Alcohol (-)-9. To a stirred solution of a diastereomeric mixture ( $\mathrm{dr}=82: 18)$ of the enone $(-)-7$ $\left(\mathrm{C}_{23} \mathrm{H}_{39} \mathrm{ClO}_{5}, 431.01 \mathrm{~g} / \mathrm{mol}, 1.5 \mathrm{~g}, 3.48 \mathrm{mmol}, 1\right.$ equiv $)$ in methanol $(174 \mathrm{~mL}, 0.02 \mathrm{M})$ at $0{ }^{\circ} \mathrm{C}$ was added cerium(III) choride heptahydrate $\left(\mathrm{CeCl}_{3} \mathrm{H}_{14} \mathrm{O}_{7}, 372.58 \mathrm{~g} / \mathrm{mol}, 1.3 \mathrm{~g}, 3.49 \mathrm{mmol}, 1\right.$ equiv) to afford a colorless solution. The reaction mixture was stirred at $0{ }^{\circ} \mathrm{C}$ until a homogenous solution was obtained. The colorless solution was cooled to $-78{ }^{\circ} \mathrm{C}$ and sodium borohydride $\left(\mathrm{NaBH}_{4}, 37.83 \mathrm{~g} / \mathrm{mol}, 395 \mathrm{mg}\right.$, $10.44 \mathrm{mmol}, 3$ equiv) was added to afford a colorless reaction mixture. The colorless reaction mixture was allowed warming to $0{ }^{\circ} \mathrm{C}$ over a period of $4 \mathrm{~h}$. The colorless solution was diluted by the addition of saturated aqueous $\mathrm{NH}_{4} \mathrm{Cl}$ solution and $\mathrm{CH}_{2} \mathrm{Cl}_{2}(v / v=1: 1)$ at $0{ }^{\circ} \mathrm{C}$. The resulting colorless biphasic mixture was transferred into a separatory funnel using $\mathrm{CH}_{2} \mathrm{Cl}_{2}$ for rinsing. The phases were separated, and the aqueous layer was extracted with $\mathrm{CH}_{2} \mathrm{Cl}_{2}(4 \times)$. The combined organic layers were dried $\left(\mathrm{MgSO}_{4}\right)$. Removal of all volatiles under reduced pressure and subsequent purification of the slightly yellow oil by 
flash chromatography (cyclohexane-ethyl acetate, 20:1 to 10:1) delivered an inseparable mixture of diastereomers of (-)-9 $\left(\mathrm{C}_{23} \mathrm{H}_{41} \mathrm{ClO}_{5}, 433.03 \mathrm{~g} / \mathrm{mol}, 1.42 \mathrm{~g}, 3.28 \mathrm{mmol}, 94 \%\right.$, dr = 82:18 according to NMR evaluation) as a colorless oil. The ratio of diastereomers was determined by integration of the ${ }^{1} \mathrm{H}$ NMR signals at $0.92 \mathrm{ppm}$ (major) and $0.98 \mathrm{ppm}$ (minor). The absolute configuration of 20-CH was tentatively assigned and later confirmed by the configurational correlation method of Mosher. $\mathrm{R}_{\mathrm{f}} 0.37$ (cyclohexaneethyl acetate, 2:1); $[\alpha]_{\mathrm{D}}{ }^{20}=-39.2\left(c=1, \mathrm{CHCl}_{3}\right)$; NMR data are reported for the major diastereomer: ${ }^{1} \mathrm{H}$ $\operatorname{NMR}\left(\mathrm{CDCl}_{3}, 500 \mathrm{MHz}\right) \delta 0.71(\mathrm{~d}, J=6.9 \mathrm{~Hz}, 3 \mathrm{H}), 0.92(\mathrm{~d}, J=6.7 \mathrm{~Hz}, 3 \mathrm{H}), 1.01(\mathrm{~d}, J=6.9 \mathrm{~Hz}, 3 \mathrm{H})$, $1.38(\mathrm{~s}, 3 \mathrm{H}), 1.46(\mathrm{~s}, 3 \mathrm{H}), 1.58(\mathrm{ddd}, J=14.6,11.2,3.3 \mathrm{~Hz}, 1 \mathrm{H}), 1.62(\mathrm{~d}, J=1.3 \mathrm{~Hz}, 3 \mathrm{H}), 1.84-1.97(\mathrm{~m}$, 2H), 1.97-2.17 (m, 3H), 2.48 (apparent dq, $J=9.3,6.8 \mathrm{~Hz}, 1 \mathrm{H}), 3.14(\mathrm{~d}, J=1.2 \mathrm{~Hz}, 1 \mathrm{H}), 3.40(\mathrm{~s}, 3 \mathrm{H})$, $3.56(\mathrm{~d}, J=6.5 \mathrm{~Hz}, 1 \mathrm{H}), 3.83(\mathrm{~d}, J=9.4 \mathrm{~Hz}, 1 \mathrm{H}), 3.89(\mathrm{dd}, J=8.5,6.5 \mathrm{~Hz}, 1 \mathrm{H}), 4.04-4.12(\mathrm{~m}, 2 \mathrm{H}), 4.24$ (apparent td, $J=6.4,5.5 \mathrm{~Hz}, 1 \mathrm{H}), 4.68(\mathrm{~d}, J=6.9 \mathrm{~Hz}, 1 \mathrm{H}), 4.74(\mathrm{~d}, J=6.5 \mathrm{~Hz}, 1 \mathrm{H}), 4.95-5.04(\mathrm{~m}, 2 \mathrm{H})$, 5.18 (dd, $J=9.5,0.9 \mathrm{~Hz}, 1 \mathrm{H}), 5.78$ (apparent ddt, $J=17.1,10.0,7.2 \mathrm{~Hz}, 1 \mathrm{H}) ;{ }^{13} \mathrm{C} \mathrm{NMR}\left(\mathrm{CDCl}_{3}, 126\right.$ MHz) $\delta 11.0\left(\mathrm{CH}_{3}\right), 14.8\left(\mathrm{CH}_{3}\right), 15.7\left(\mathrm{CH}_{3}\right), 20.4\left(\mathrm{CH}_{3}\right), 25.4\left(\mathrm{CH}_{3}\right), 26.4\left(\mathrm{CH}_{3}\right), 31.9(\mathrm{CH}), 32.1(\mathrm{CH})$, $38.2\left(\mathrm{CH}_{2}\right), 39.7(\mathrm{CH}), 41.6\left(\mathrm{CH}_{2}\right), 56.2\left(\mathrm{CH}_{3}\right), 61.1(\mathrm{CH}), 66.5\left(\mathrm{CH}_{2}\right), 79.0(\mathrm{CH}), 81.8(\mathrm{CH}), 84.5(\mathrm{CH})$, $98.1\left(\mathrm{CH}_{2}\right), 110.1(\mathrm{C}), 115.8\left(\mathrm{CH}_{2}\right), 134.3(\mathrm{C}), 134.8(\mathrm{CH}), 137.3(\mathrm{CH}) ; \mathrm{IR} \vee 3485(\mathrm{w}), 2960(\mathrm{w}), 1640$ (w), $1455(\mathrm{w}), 1370(\mathrm{~m}), 1255(\mathrm{w}), 1215(\mathrm{~m}), 1155(\mathrm{~m}), 1035(\mathrm{~s}), 910(\mathrm{~m}), 855(\mathrm{~m}), 685(\mathrm{w}), 510(\mathrm{w}) \mathrm{cm}^{-}$ 1; Anal. Calcd. for $\mathrm{C}_{23} \mathrm{H}_{41} \mathrm{ClO}_{5}$ : C, 63.8; H, 9.5; Found: C, 63.9; H, 9.6.

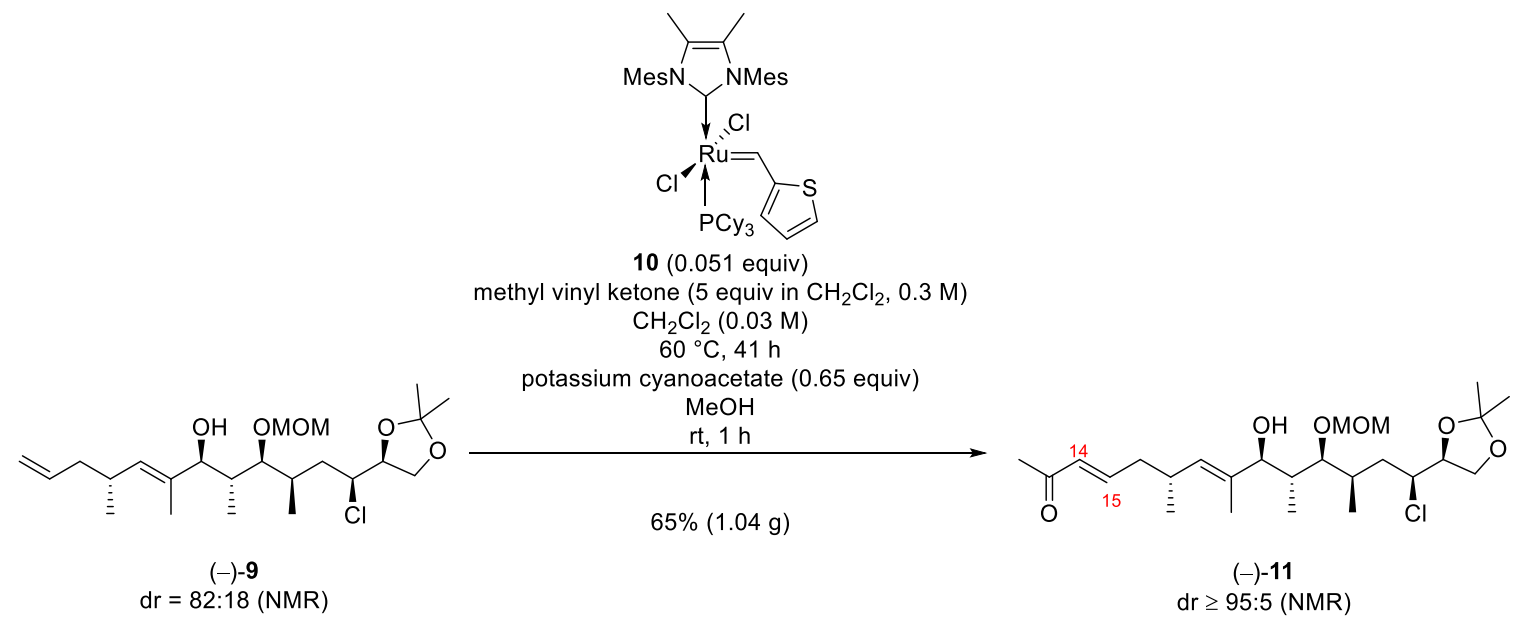

Enone (-)-11. Note: The reaction was carried out in parallel in two batches. Two sealable glass pressure tubes were charged with a diastereomeric mixture $(\mathrm{dr}=82: 18)$ of allyl alcohol $(-)-9\left(\mathrm{C}_{23} \mathrm{H}_{41} \mathrm{ClO}_{5}, 433.03\right.$ $\mathrm{g} / \mathrm{mol}, 1.46 \mathrm{~g}$ [2× $730 \mathrm{mg}$ ], $3.37 \mathrm{mmol}, 1$ equiv) in $\mathrm{CH}_{2} \mathrm{Cl}_{2}(113 \mathrm{~mL}$ [2×56.5 mL], $0.03 \mathrm{M}$, degassed by three freeze-pump-thaw-cycles) to afford two colorless solutions. A solution of freshly distilled $\left(95{ }^{\circ} \mathrm{C}\right)$ methyl vinyl ketone $\left(\mathrm{C}_{4} \mathrm{H}_{6} \mathrm{O}, 70.09 \mathrm{~g} / \mathrm{mol}, 0.864 \mathrm{~g} / \mathrm{mL}, 1.38 \mathrm{~mL}\right.$ [2×690 $\left.\mu \mathrm{L}\right], 1.19 \mathrm{~g}$ [2×595 mg], 16.98 mmol, 5 equiv) in $\mathrm{CH}_{2} \mathrm{Cl}_{2}(56 \mathrm{~mL}$ [2×28 mL], $0.3 \mathrm{M}$, degassed by three freeze-pump-thaw-cycles) (overall: $0.02 \mathrm{M}$ in (-)-9 in $\mathrm{CH}_{2} \mathrm{Cl}_{2}$ ), and catMETium ${ }^{\circledR} \mathrm{RF} 3 \mathrm{10}\left(\mathrm{C}_{46} \mathrm{H}_{65} \mathrm{Cl}_{2} \mathrm{~N}_{2} \mathrm{PRuS}, 881.04 \mathrm{~g} / \mathrm{mol}, 150 \mathrm{mg}\right.$ [ $2 \times 75 \mathrm{mg}$ ], $170 \mu \mathrm{mol}, 0.051$ equiv) were added at ambient temperature to both solutions to afford two brown solutions. The tubes were sealed with Teflon screw caps and placed in a pre-heated oil bath (60 $\left.{ }^{\circ} \mathrm{C}\right)$. After being stirred for $41 \mathrm{~h}$ at $60{ }^{\circ} \mathrm{C}$, the resulting two dark brown reaction mixtures were cooled to ambient temperature and transferred into a single round-bottomed flask using $\mathrm{CH}_{2} \mathrm{Cl}_{2}$ for rinsing. Removal of volatiles under reduced pressure $\left(40{ }^{\circ} \mathrm{C}, 640 \mathrm{mbar}\right)$ delivered a black liquid. Methanol (68 $\mathrm{mL})$ and potassium cyanoacetate $\left(\mathrm{C}_{3} \mathrm{H}_{2} \mathrm{KNO}_{2}, 123.15 \mathrm{~g} / \mathrm{mol}, 318 \mathrm{mg}, 85 \%\right.$ purity, $270 \mathrm{mg}, 2.19 \mathrm{mmol}$, 0.65 equiv) were added and stirring was continued at ambient temperature for $1 \mathrm{~h}$. Removal of all volatiles under reduced pressure and subsequent purification of the black oil by flash chromatography (cyclohexane-ethyl acetate, 5:1 to 2:1) delivered (-)-11 $\left(\mathrm{C}_{25} \mathrm{H}_{43} \mathrm{ClO}_{6}, 475.06 \mathrm{~g} / \mathrm{mol}, 1.04 \mathrm{~g}, 2.19 \mathrm{mmol}\right.$, $65 \%$, $d r \geq 95: 5$ according to NMR evaluation) as a viscos colorless oil. The configuration of the 14$\mathrm{CH} / 15-\mathrm{CH}$ double bond was assigned by coupling constant analysis: 6.75 (apparent dt, $J=15.7,7.3 \mathrm{~Hz}$, $1 \mathrm{H}) . \mathrm{R}_{\mathrm{f}} 0.34$ (cyclohexane-ethyl acetate, $\left.1: 1\right) ;[\alpha]_{\mathrm{D}}{ }^{20}=-40.8\left(c=1, \mathrm{CHCl}_{3}\right) ;{ }^{1} \mathrm{H} \mathrm{NMR}\left(\mathrm{CDCl}_{3}, 500 \mathrm{MHz}\right)$ $\delta 0.71(\mathrm{~d}, J=6.9 \mathrm{~Hz}, 3 \mathrm{H}), 0.97(\mathrm{~d}, J=6.7 \mathrm{~Hz}, 3 \mathrm{H}), 1.01(\mathrm{~d}, J=6.9 \mathrm{~Hz}, 3 \mathrm{H}), 1.37(\mathrm{~s}, 3 \mathrm{H}), 1.46(\mathrm{~s}, 3 \mathrm{H})$, 
$1.58(\mathrm{ddd}, J=14.8,11.6,3.6 \mathrm{~Hz}, 1 \mathrm{H}), 1.63(\mathrm{~s}, 3 \mathrm{H}), 1.85-1.97(\mathrm{~m}, 2 \mathrm{H}), 2.08-2.16(\mathrm{~m}, 1 \mathrm{H}), 2.16-2.29(\mathrm{~m}$, 5H), 2.59 (apparent dsxt, $J=9.2,6.8 \mathrm{~Hz}, 1 \mathrm{H}), 3.29(\mathrm{~s}, 1 \mathrm{H}), 3.40(\mathrm{~s}, 3 \mathrm{H}), 3.54(\mathrm{~d}, J=7.4 \mathrm{~Hz}, 1 \mathrm{H}), 3.83(\mathrm{~d}$, $J=9.4 \mathrm{~Hz}, 1 \mathrm{H}), 3.90(\mathrm{dd}, J=8.5,6.5 \mathrm{~Hz}, 1 \mathrm{H}), 4.04-4.11(\mathrm{~m}, 2 \mathrm{H}), 4.24$ (apparent td, $J=6.6,5.4 \mathrm{~Hz}, 1 \mathrm{H})$, $4.69(\mathrm{~d}, J=7.0 \mathrm{~Hz}, 1 \mathrm{H}), 4.74(\mathrm{~d}, J=6.7 \mathrm{~Hz}, 1 \mathrm{H}), 5.19(\mathrm{~d}, J=9.3 \mathrm{~Hz}, 1 \mathrm{H}), 6.07(\mathrm{~d}, J=15.9 \mathrm{~Hz}, 1 \mathrm{H}), 6.75$ (apparent dt, $J=15.7,7.3 \mathrm{~Hz}, 1 \mathrm{H}) ;{ }^{13} \mathrm{C} \mathrm{NMR}\left(\mathrm{CDCl}_{3}, 126 \mathrm{MHz}\right) \delta 11.2\left(\mathrm{CH}_{3}\right), 14.9\left(\mathrm{CH}_{3}\right), 15.6\left(\mathrm{CH}_{3}\right)$, $20.6\left(\mathrm{CH}_{3}\right), 25.3\left(\mathrm{CH}_{3}\right), 26.4\left(\mathrm{CH}_{3}\right), 27.0\left(\mathrm{CH}_{3}\right), 31.8(\mathrm{CH}), 32.0(\mathrm{CH}), 38.0\left(\mathrm{CH}_{2}\right), 39.7(\mathrm{CH}), 40.1$ $\left(\mathrm{CH}_{2}\right), 56.3\left(\mathrm{CH}_{3}\right), 61.1(\mathrm{CH}), 66.5\left(\mathrm{CH}_{2}\right), 78.9(\mathrm{CH}), 81.7(\mathrm{CH}), 84.8(\mathrm{CH}), 98.2\left(\mathrm{CH}_{2}\right), 110.1(\mathrm{C}), 132.7$ $(\mathrm{CH}), 133.6(\mathrm{CH}), 135.4(\mathrm{C}), 146.8(\mathrm{CH}), 198.9(\mathrm{C})$; IR $v 2965(\mathrm{w}), 1630(\mathrm{~s}), 1560(\mathrm{w}), 1455(\mathrm{w}), 1370$ (m), 1255 (m), 1215 (m), 1155 (m), 1095 (m), 1065 (m), 1035 (s), 980 (w), 915 (w), 855 (w), 745 (s), 700 (w), $665(\mathrm{w}) \mathrm{cm}^{-1}$; Anal. Calcd. for $\mathrm{C}_{25} \mathrm{H}_{43} \mathrm{ClO}_{6}$ : C, 63.2; H, 9.1; Found: C, 63.0; H, 9.1.

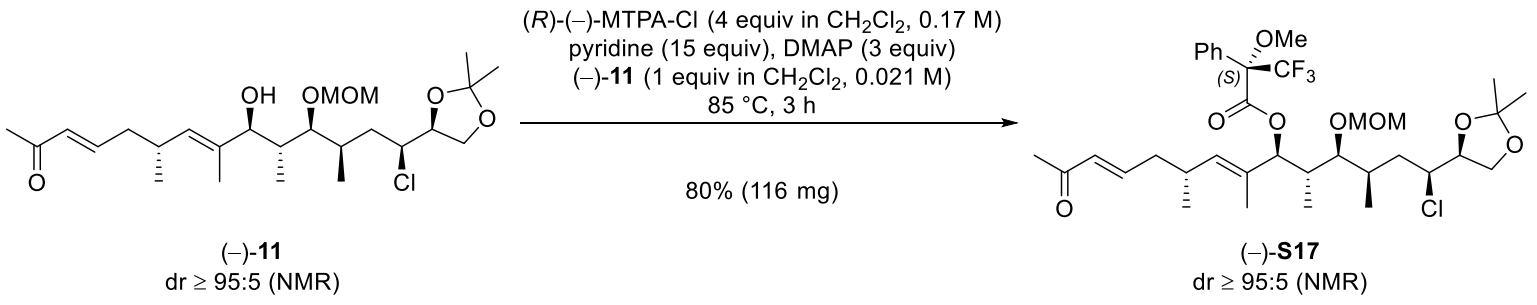

(S)-Mosher Ester (-)-S17. A sealable glass pressure tube was charged with $(R)-(-)$ - $\alpha$-methoxy- $\alpha$ (trifluoromethyl)phenylacetyl chloride $\left((R)-(-)-\mathrm{MTPA}-\mathrm{Cl}, \mathrm{C}_{10} \mathrm{H}_{8} \mathrm{ClF}_{3} \mathrm{O}_{2}, 252.62 \mathrm{~g} / \mathrm{mol}, 1.35 \mathrm{~g} / \mathrm{mL}, 158\right.$ $\mu \mathrm{L}, 213 \mathrm{mg}, 842 \mu \mathrm{mol}, 4$ equiv) in $\mathrm{CH}_{2} \mathrm{Cl}_{2}(5 \mathrm{~mL}, 0.17 \mathrm{M})$ to afford a colorless solution. Pyridine $\left(\mathrm{C}_{5} \mathrm{H}_{5} \mathrm{~N}, 79.1 \mathrm{~g} / \mathrm{mol}, 0.98 \mathrm{~g} / \mathrm{mL}, 255 \mu \mathrm{L}, 250 \mathrm{mg}, 3.16 \mathrm{mmol}, 15\right.$ equiv), 4-(dimethylamino)pyridine (DMAP, $\mathrm{C}_{7} \mathrm{H}_{10} \mathrm{~N}_{2}, 122.17 \mathrm{~g} / \mathrm{mol}, 77 \mathrm{mg}, 630 \mu \mathrm{mol}, 3$ equiv) and, enone (-)-11 $\left(\mathrm{C}_{25} \mathrm{H}_{43} \mathrm{ClO}_{6}, 475.06\right.$ $\mathrm{g} / \mathrm{mol}, 100 \mathrm{mg}, 210 \mu \mathrm{mol}, 1$ equiv) dissolved in $\mathrm{CH}_{2} \mathrm{Cl}_{2}\left(10 \mathrm{~mL}, 0.021 \mathrm{M}\right.$; overall: $0.014 \mathrm{M}$ in $\left.\mathrm{CH}_{2} \mathrm{Cl}_{2}\right)$ were added at ambient temperature to afford a colorless reaction mixture. The tube was sealed with a Teflon screw cap and placed in a pre-heated oil bath $\left(85^{\circ} \mathrm{C}\right)$. After being stirred for $3 \mathrm{~h}$ at $85{ }^{\circ} \mathrm{C}$, the resulting yellow cloudy solution was diluted by the addition of saturated aqueous $\mathrm{NH}_{4} \mathrm{Cl}$ solution at ambient temperature. The resulting yellow biphasic mixture was transferred into a separatory funnel using $\mathrm{CH}_{2} \mathrm{Cl}_{2}$ for rinsing. The phases were separated, and the aqueous layer was extracted with $\mathrm{CH}_{2} \mathrm{Cl}_{2}(4 \times)$. The combined organic layers were dried $\left(\mathrm{MgSO}_{4}\right)$. Removal of all volatiles under reduced pressure and subsequent purification of the remaining yellow oil by flash chromatography (cyclohexane-ethyl acetate, 10:1 to 2:1) delivered (-)-S17 $\left(\mathrm{C}_{35} \mathrm{H}_{50} \mathrm{ClF}_{3} \mathrm{O}_{8}, 691.22 \mathrm{~g} / \mathrm{mol}, 116 \mathrm{mg}, 168 \mu \mathrm{mol}, 80 \%\right.$, dr $\geq 95: 5$ according to NMR evaluation) as a colorless oil. $\mathrm{R}_{\mathrm{f}} 0.43$ (cyclohexane-ethyl acetate, $\left.2: 1\right) ;[\alpha]_{\mathrm{D}}{ }^{20}=-32.9(c=1$, $\left.\mathrm{CHCl}_{3}\right) ;{ }^{1} \mathrm{H} \mathrm{NMR}\left(\mathrm{CDCl}_{3}, 500 \mathrm{MHz}\right) \delta 0.84\left(\mathrm{~d}, J=7.2 \mathrm{~Hz}, 3 \mathrm{H}, 21^{\prime}-\mathrm{CH}_{3}\right), 0.87\left(\mathrm{~d}, J=6.5 \mathrm{~Hz}, 3 \mathrm{H}, 23{ }^{\prime}-\right.$ $\left.\mathrm{CH}_{3}\right), 0.98\left(\mathrm{~d}, J=6.7 \mathrm{~Hz}, 3 \mathrm{H}, 17{ }^{\prime}-\mathrm{CH}_{3}\right), 1.37\left(\mathrm{~s}, 3 \mathrm{H}\right.$, acetonide- $\left.\mathrm{CH}_{3}\right), 1.46\left(\mathrm{~s}, 3 \mathrm{H}\right.$, acetonide- $\left.\mathrm{CH}_{3}\right), 1.53$ (ddd, $\left.J=13.4,9.6,4.1 \mathrm{~Hz}, 1 \mathrm{H}, 24-\mathrm{CH}_{2}\right), 1.59$ (s, 3H, 19'- $\left.\mathrm{CH}_{3}\right), 1.85-1.96$ (m, 2H, 24-CH $\left.2+23-\mathrm{CH}\right), 2.13$ (s, 3H, 12- $\mathrm{CH}_{3}$ ), 2.15-2.27 (m, 3H, 16- $\left.\mathrm{CH}_{2}+21-\mathrm{CH}\right), 2.57$ (apparent dsxt, $J=9.1,6.9 \mathrm{~Hz}, 1 \mathrm{H}, 17-\mathrm{CH}$ ), $3.28(\mathrm{dd}, J=4.9,2.3 \mathrm{~Hz}, 1 \mathrm{H}, 22-\mathrm{CH}), 3.34$ (s, 3H, MOM-CH 3$), 3.50\left(\mathrm{~s}, 3 \mathrm{H},-\mathrm{OCH}_{3}\right), 3.85-3.91(\mathrm{~m}, 2 \mathrm{H}$, $\left.25-\mathrm{CH}+27-\mathrm{CH}_{2}\right), 4.05\left(\mathrm{dd}, J=8.3,6.8 \mathrm{~Hz}, 1 \mathrm{H}, 27-\mathrm{CH}_{2}\right), 4.20$ (apparent td, $J=6.5,4.8 \mathrm{~Hz}, 1 \mathrm{H}, 26-\mathrm{CH}_{2}$ ), $4.50\left(\mathrm{~d}, J=6.8 \mathrm{~Hz}, 1 \mathrm{H}, \mathrm{MOM}-\mathrm{CH}_{2}\right), 4.57\left(\mathrm{~d}, J=6.9 \mathrm{~Hz}, 1 \mathrm{H}, \mathrm{MOM}_{-} \mathrm{CH}_{2}\right), 5.29$ (d, $J=9.0 \mathrm{~Hz}, 1 \mathrm{H}, 20-$ $\mathrm{CH}), 5.42(\mathrm{~d}, J=9.5 \mathrm{~Hz}, 1 \mathrm{H}, 18-\mathrm{CH}), 6.05(\mathrm{~d}, J=15.9 \mathrm{~Hz}, 1 \mathrm{H}, 14-\mathrm{CH}), 6.69$ (apparent dt, $J=15.5,7.3$ $\mathrm{Hz}, 1 \mathrm{H}, 15-\mathrm{CH}), 7.34-7.41(\mathrm{~m}, 3 \mathrm{H}, 3 \times \mathrm{Ph}-\mathrm{CH}), 7.49(\mathrm{~d}, J=7.7 \mathrm{~Hz}, 2 \mathrm{H}, 2 \times \mathrm{Ph}-\mathrm{CH}) ;{ }^{13} \mathrm{C} \mathrm{NMR}\left(\mathrm{CDCl}_{3}\right.$, $126 \mathrm{MHz}) \delta 12.4\left(\mathrm{CH}_{3}\right), 13.9\left(\mathrm{CH}_{3}\right), 15.9\left(\mathrm{CH}_{3}\right), 20.6\left(\mathrm{CH}_{3}\right), 25.4\left(\mathrm{CH}_{3}\right), 26.3\left(\mathrm{CH}_{3}\right), 26.8\left(\mathrm{CH}_{3}\right), 32.1$ $(\mathrm{CH}), 32.2(\mathrm{CH}), 38.5(\mathrm{CH}), 38.8\left(\mathrm{CH}_{2}\right), 40.0\left(\mathrm{CH}_{2}\right), 55.4\left(\mathrm{CH}_{3}\right), 55.9\left(\mathrm{CH}_{3}\right), 60.7(\mathrm{CH}), 66.6\left(\mathrm{CH}_{2}\right), 78.2$ $(\mathrm{CH}), 82.2(\mathrm{CH}), 83.7(\mathrm{CH}), 84.5(\mathrm{q}, J=27.9 \mathrm{~Hz}, \mathrm{C}), 98.1\left(\mathrm{CH}_{2}\right), 110.0(\mathrm{C}), 123.6(\mathrm{q}, J=288.3 \mathrm{~Hz}, \mathrm{C})$, $127.7(\mathrm{CH}), 128.4(\mathrm{CH}), 129.7(\mathrm{CH}), 130.7(\mathrm{C}), 132.3(\mathrm{C}), 132.8(\mathrm{CH}), 137.3(\mathrm{CH}), 146.0(\mathrm{CH}), 165.6$ (C), $198.9(\mathrm{C}) ;{ }^{19} \mathrm{~F} \mathrm{NMR}\left(\mathrm{CDCl}_{3}, 565 \mathrm{MHz}\right) \delta$-71.0; IR $\vee 2955(\mathrm{w}), 1745(\mathrm{~m}), 1675(\mathrm{~m}), 1630(\mathrm{w}), 1455$ (w), 1370 (w), 1250 (s), 1165 (s), 1120 (m), 1070 (m), 1030 (s), 985 (s), 915 (m), 855 (w), 765 (w), 720 (m), $700(\mathrm{w}), 510(\mathrm{w}) \mathrm{cm}^{-1}$; HRMS (ESI): $\mathrm{m} / \mathrm{z}[\mathrm{M}+\mathrm{Na}]^{+}$Calcd. for $\mathrm{C}_{35} \mathrm{H}_{50} \mathrm{ClF}_{3} \mathrm{NaO}_{8}$ : 713.30385; Found: 713.30332 . 


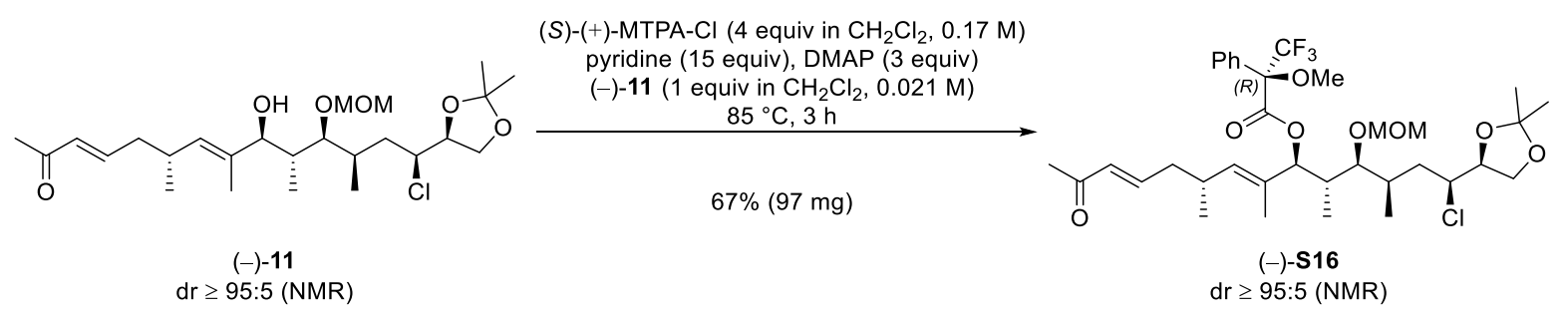

$(\boldsymbol{R})$-Mosher Ester (-)-S16. A sealable glass pressure tube was charged with $(S)-(+)$ - $\alpha$-methoxy- $\alpha$ (trifluoromethyl)phenylacetyl chloride $\left((S)-(+)-\mathrm{MTPA}-\mathrm{Cl}, \mathrm{C}_{10} \mathrm{H}_{8} \mathrm{ClF}_{3} \mathrm{O}_{2}, 252.62 \mathrm{~g} / \mathrm{mol}, 1.35 \mathrm{~g} / \mathrm{mL}, 158\right.$ $\mu \mathrm{L}, 213 \mathrm{mg}, 843 \mu \mathrm{mol}, 4$ equiv) in $\mathrm{CH}_{2} \mathrm{Cl}_{2}(5 \mathrm{~mL}, 0.17 \mathrm{M})$ to afford a colorless solution. Pyridine $\left(\mathrm{C}_{5} \mathrm{H}_{5} \mathrm{~N}, 79.1 \mathrm{~g} / \mathrm{mol}, 0.98 \mathrm{~g} / \mathrm{mL}, 255 \mu \mathrm{L}, 250 \mathrm{mg}, 3.16 \mathrm{mmol}, 15\right.$ equiv), 4-(dimethylamino)pyridine (DMAP, $\mathrm{C}_{7} \mathrm{H}_{10} \mathrm{~N}_{2}, 122.17 \mathrm{~g} / \mathrm{mol}, 77 \mathrm{mg}, 630 \mu \mathrm{mol}, 3$ equiv) and, enone (-)-11 $\left(\mathrm{C}_{25} \mathrm{H}_{43} \mathrm{ClO}_{6}, 475.06\right.$ $\mathrm{g} / \mathrm{mol}, 100 \mathrm{mg}, 210 \mu \mathrm{mol}, 1$ equiv) dissolved in $\mathrm{CH}_{2} \mathrm{Cl}_{2}\left(10 \mathrm{~mL}, 0.021 \mathrm{M}\right.$; overall: $0.014 \mathrm{M}$ in $\left.\mathrm{CH}_{2} \mathrm{Cl}_{2}\right)$ were added at ambient temperature to afford a colorless reaction mixture. The tube was sealed with a Teflon screw cap and placed in a pre-heated oil bath $\left(85^{\circ} \mathrm{C}\right)$. After being stirred for $3 \mathrm{~h}$ at $85{ }^{\circ} \mathrm{C}$, the resulting yellow cloudy solution was diluted by the addition of saturated aqueous $\mathrm{NH}_{4} \mathrm{Cl}$ solution at ambient temperature. The resulting yellow biphasic mixture was transferred into a separatory funnel using $\mathrm{CH}_{2} \mathrm{Cl}_{2}$ for rinsing. The phases were separated, and the aqueous layer was extracted with $\mathrm{CH}_{2} \mathrm{Cl}_{2}(4 \times)$. The combined organic layers were dried $\left(\mathrm{MgSO}_{4}\right)$. Removal of all volatiles under reduced pressure and subsequent purification of the remaining yellow oil by flash chromatography (cyclohexane-ethyl acetate, 10:1 to 2:1) delivered (-)-S16 $\left(\mathrm{C}_{35} \mathrm{H}_{50} \mathrm{ClF}_{3} \mathrm{O}_{8}, 691.22 \mathrm{~g} / \mathrm{mol}, 97 \mathrm{mg}, 140 \mu \mathrm{mol}, 67 \%\right.$, $\mathrm{dr} \geq 95: 5$ according to NMR evaluation) as a colorless oil. $\mathrm{R}_{\mathrm{f}} 0.43$ (cyclohexane-ethyl acetate, $\left.2: 1\right) ;[\alpha]_{\mathrm{D}}{ }^{20}=-2.9(c=1$, $\left.\mathrm{CHCl}_{3}\right) ;{ }^{1} \mathrm{H} \mathrm{NMR}\left(\mathrm{CDCl}_{3}, 500 \mathrm{MHz}\right) \delta 0.84\left(\mathrm{~d}, J=7.2 \mathrm{~Hz}, 3 \mathrm{H}, 21^{\prime}-\mathrm{CH}_{3}\right), 0.96\left(\mathrm{~d}, J=6.8 \mathrm{~Hz}, 6 \mathrm{H}, 23{ }^{\prime}-\right.$ $\left.\mathrm{CH}_{3}+17^{\prime}-\mathrm{CH}_{3}\right), 1.34\left(\mathrm{~s}, 3 \mathrm{H}\right.$, acetonide- $\left.\mathrm{CH}_{3}\right), 1.43\left(\mathrm{~s}, 6 \mathrm{H}\right.$, acetonide- $\mathrm{CH}_{3}+19$ '- $\left.\mathrm{CH}_{3}\right), 1.56$ (ddd, $J=14.9$, $\left.10.5,4.7 \mathrm{~Hz}, 1 \mathrm{H}, 24-\mathrm{CH}_{2}\right), 1.89$ (ddd, $\left.J=13.4,9.6,4.1 \mathrm{~Hz}, 1 \mathrm{H}, 24-\mathrm{CH}_{2}\right), 1.96-2.06(\mathrm{~m}, 1 \mathrm{H}, 23-\mathrm{CH})$, 2.15-2.27 (m, 6H, 16- $\left.\mathrm{CH}_{2}+21-\mathrm{CH}+12-\mathrm{CH}_{3}\right), 2.53$ (apparent dsxt, $\left.J=9.1,7.0 \mathrm{~Hz}, 1 \mathrm{H}, 17-\mathrm{CH}\right), 3.33$ (dd, $J$ $=6.0,2.3 \mathrm{~Hz}, 1 \mathrm{H}, 22-\mathrm{CH}), 3.35\left(\mathrm{~s}, 3 \mathrm{H}, \mathrm{MOM}-\mathrm{CH}_{3}\right), 3.53\left(\mathrm{~s}, 3 \mathrm{H},-\mathrm{OCH}_{3}\right), 3.85(\mathrm{dd}, J=8.4,6.4 \mathrm{~Hz}, 1 \mathrm{H}$, 27- $\mathrm{CH}_{2}$ ), 3.90 (apparent dt, $J=10.6,4.1 \mathrm{~Hz}, 1 \mathrm{H}, 25-\mathrm{CH}$ ), 4.00 (dd, $J=8.3,6.8 \mathrm{~Hz}, 1 \mathrm{H}, 27-\mathrm{CH}_{2}$ ), 4.18 (apparent td, $J=6.3,4.9 \mathrm{~Hz}, 1 \mathrm{H}, 26-\mathrm{CH}), 4.55\left(\mathrm{~d}, J=7.0 \mathrm{~Hz}, 1 \mathrm{H}, \mathrm{MOM}-\mathrm{CH}_{2}\right), 4.64(\mathrm{~d}, J=7.0 \mathrm{~Hz}, 1 \mathrm{H}$, MOM-CH 2$), 5.29$ (d, $J=8.9 \mathrm{~Hz}, 1 \mathrm{H}, 20-\mathrm{CH}), 5.37(\mathrm{~d}, J=9.4 \mathrm{~Hz}, 1 \mathrm{H}, 18-\mathrm{CH}), 6.07(\mathrm{~d}, J=15.9 \mathrm{~Hz}, 1 \mathrm{H}$, 14-CH), 6.73 (apparent dt, $J=15.4,7.4 \mathrm{~Hz}, 1 \mathrm{H}, 15-\mathrm{CH}), 7.33-7.41(\mathrm{~m}, 3 \mathrm{H}, 3 \times \mathrm{Ph}-\mathrm{CH}), 7.53(\mathrm{~d}, J=7.7$ $\mathrm{Hz}, 2 \mathrm{H}, 2 \times \mathrm{Ph}-\mathrm{CH}) ;{ }^{13} \mathrm{C} \mathrm{NMR}\left(\mathrm{CDCl}_{3}, 126 \mathrm{MHz}\right) \delta 12.0\left(\mathrm{CH}_{3}\right), 14.5\left(\mathrm{CH}_{3}\right), 15.8\left(\mathrm{CH}_{3}\right), 20.5\left(\mathrm{CH}_{3}\right), 25.3$ $\left(\mathrm{CH}_{3}\right), 26.3\left(\mathrm{CH}_{3}\right), 26.9\left(\mathrm{CH}_{3}\right), 32.0(\mathrm{CH}), 32.4(\mathrm{CH}), 38.2(\mathrm{CH}), 38.3\left(\mathrm{CH}_{2}\right), 40.0\left(\mathrm{CH}_{2}\right), 55.5\left(\mathrm{CH}_{3}\right)$, $56.0\left(\mathrm{CH}_{3}\right), 60.8(\mathrm{CH}), 66.5\left(\mathrm{CH}_{2}\right), 78.3(\mathrm{CH}), 83.0(\mathrm{CH}), 84.0(\mathrm{CH}), 84.6(\mathrm{q}, J=27.6 \mathrm{~Hz}, \mathrm{C}), 98.4\left(\mathrm{CH}_{2}\right)$, $110.0(\mathrm{C}), 123.5$ (q, $J=289.0 \mathrm{~Hz}, \mathrm{C}), 127.7(\mathrm{CH}), 128.4(\mathrm{CH}), 129.7(\mathrm{CH}), 130.7(\mathrm{C}), 132.3(\mathrm{C}), 132.8$ $(\mathrm{CH}), 137.1(\mathrm{CH}), 146.1(\mathrm{CH}), 165.7(\mathrm{C}), 198.9(\mathrm{C}) ;{ }^{19} \mathrm{~F} \mathrm{NMR}\left(\mathrm{CDCl}_{3}, 565 \mathrm{MHz}\right) \delta-71.2 ; \mathrm{IR} v 2955(\mathrm{w})$, 1745 (m), 1675 (m), 1630 (w), 1455 (w), 1370 (w), 1255 (s), 1165 (s), 1120 (m), 1070 (m), 1030 (s), 915 (m), $855(\mathrm{w}), 765(\mathrm{w}), 720(\mathrm{~m}), 700(\mathrm{w}), 545(\mathrm{w}) \mathrm{cm}^{-1}$; HRMS (ESI): m/z [M + Na] $]^{+}$Calcd. for $\mathrm{C}_{35} \mathrm{H}_{50} \mathrm{ClF}_{3} \mathrm{NaO}_{8}$ : 713.30385; Found: 713.30337.
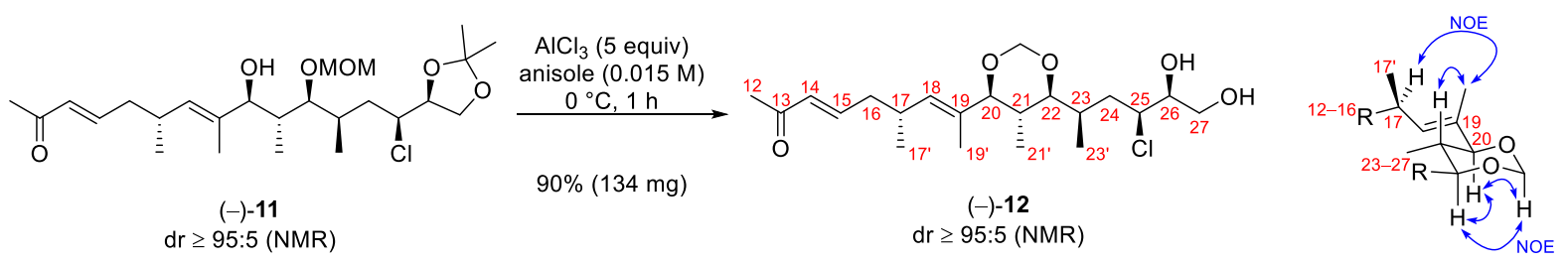

Methylene Acetal (-)-12. To a stirred solution of the enone (-)-11 $\left(\mathrm{C}_{25} \mathrm{H}_{43} \mathrm{ClO}_{6}, 475.06 \mathrm{~g} / \mathrm{mol}, 175 \mathrm{mg}\right.$, $368 \mu \mathrm{mol}, 1$ equiv) in anisole $(25 \mathrm{~mL}, 0.015 \mathrm{M})$ at $0{ }^{\circ} \mathrm{C}$ was added anhydrous aluminium(III) chloride $\left(\mathrm{AlCl}_{3}, 133.34 \mathrm{~g} / \mathrm{mol}, 246 \mathrm{mg}, 1.84 \mathrm{mmol}, 5\right.$ equiv) to afford a slightly yellow suspension. After being stirred for $1 \mathrm{~h}$ at $0{ }^{\circ} \mathrm{C}$, the yellow suspension was diluted by the addition of saturated aqueous $\mathrm{NaHCO}_{3}$ solution at $0{ }^{\circ} \mathrm{C}$. The resulting yellow biphasic mixture was transferred into a separatory funnel using 
ethyl acetate for rinsing. The phases were separated, and the aqueous layer was extracted with ethyl acetate $(6 \times)$. The combined organic layers were dried $\left(\mathrm{MgSO}_{4}\right)$. Removal of all volatiles under reduced pressure and subsequent purification of the yellow oil by flash chromatography (cyclohexane-ethyl acetate, 5:1 to 1:2) delivered (-)-12 $\left(\mathrm{C}_{21} \mathrm{H}_{35} \mathrm{ClO}_{5}, 402.96 \mathrm{~g} / \mathrm{mol}, 134 \mathrm{mg}, 333 \mu \mathrm{mol}, 90 \%\right.$, dr $\geq 95: 5$ according to NMR evaluation) as a colorless oil. The assignment of the absolute configuration of 20-CH, 21-CH and 22-CH rests on the interpretation of the results of a NOE experiment and the ${ }^{1} \mathrm{H}$ NMR data of the Mosher esters $(S)-(-)-S 17$ and $(R)-(-)-S 16$. The ${ }^{1} \mathrm{H}$ NMR chemical shifts for $(S)-(-)$-S17 and $(R)-(-)-$ S16 suggest a $20 S$ configuration (Figure SI-1-2). NOE correlation observed between acetal- $\mathrm{CH}_{2}{ }^{R e}$ and 20$\mathrm{CH}$, acetal- $\mathrm{CH}_{2}{ }^{R e}$ and $22-\mathrm{CH}, 20-\mathrm{CH}$ and $22-\mathrm{CH}, 20-\mathrm{CH}$ and $21^{\prime}-\mathrm{CH}_{3}$ as well as $22-\mathrm{CH}$ and $21^{\prime}-\mathrm{CH}_{3}$. The assignment of the configuration of the trisubstituted double bond between $18-\mathrm{CH}$ and $19-\mathrm{C}$ rest on the interpretation of the results of a NOE experiment. NOE correlation observed between $18-\mathrm{CH}$ and $20-\mathrm{CH}$, $17-\mathrm{CH}$ and $19^{\prime}-\mathrm{CH}_{3}$ as well as $21-\mathrm{CH}$ and $19^{\prime}-\mathrm{CH}_{3} . \mathrm{R}_{\mathrm{f}} 0.4\left(\mathrm{CH}_{2} \mathrm{Cl}_{2}-\right.$ methanol, 10:1); $[\alpha]_{\mathrm{D}}{ }^{25}=-57.5(c=1$, $\left.\mathrm{CHCl}_{3}\right) ;{ }^{1} \mathrm{H} \mathrm{NMR}\left(\mathrm{CDCl}_{3}, 400 \mathrm{MHz}\right) \delta 0.64\left(\mathrm{~d}, J=6.7 \mathrm{~Hz}, 3 \mathrm{H}, 21{ }^{\prime}-\mathrm{CH}_{3}\right), 0.96(\mathrm{~d}, J=7.0 \mathrm{~Hz}, 3 \mathrm{H}, 23$ '$\left.\mathrm{CH}_{3}\right), 0.99\left(\mathrm{~d}, J=6.7 \mathrm{~Hz}, 3 \mathrm{H}, 17{ }^{\prime}-\mathrm{CH}_{3}\right), 1.66$ (d, $\left.J=1.4 \mathrm{~Hz}, 3 \mathrm{H}, 19 '-\mathrm{CH}_{3}\right), 1.71-1.89$ (m, 2H, 21-CH+24$\mathrm{CH}_{2}$ ), 1.96 (ddd, $\left.J=14.1,9.9,3.5 \mathrm{~Hz}, 1 \mathrm{H}, 24-\mathrm{CH}_{2}\right), 2.08-2.17(\mathrm{~m}, 1 \mathrm{H}, 23-\mathrm{CH}), 2.17-2.29$ (m, 6H, 16$\left.\mathrm{CH}_{2}+12-\mathrm{CH}_{3}+-\mathrm{OH}\right), 2.55-2.66(\mathrm{~m}, 2 \mathrm{H}, 17-\mathrm{CH}+-\mathrm{OH}), 3.25(\mathrm{dd}, J=9.7,2.2 \mathrm{~Hz}, 1 \mathrm{H}, 22-\mathrm{CH}), 3.52(\mathrm{~d}, J=$ $\left.9.8 \mathrm{~Hz}, 1 \mathrm{H}, 20-\mathrm{CH}_{2}\right), 3.66-3.77\left(\mathrm{~m}, 3 \mathrm{H}, 26-\mathrm{CH}+27-\mathrm{CH}_{2}\right), 4.11$ (apparent dt, $J=11.1,3.6 \mathrm{~Hz}, 1 \mathrm{H}, 25-$ $\mathrm{CH}), 4.73\left(\mathrm{~d}, J=6.1 \mathrm{~Hz}, 1 \mathrm{H}\right.$, acetal- $\left.\mathrm{CH}_{2}{ }^{R e}\right), 5.08\left(\mathrm{~d}, J=6.1 \mathrm{~Hz}, 1 \mathrm{H}\right.$, acetal- $\left.\mathrm{CH}_{2}{ }^{S i}\right), 5.24(\mathrm{dd}, J=9.3,1.3$ $\mathrm{Hz}, 1 \mathrm{H}, 18-\mathrm{CH}$ ), 6.06 (apparent dt, $J=15.9,1.3 \mathrm{~Hz}, 1 \mathrm{H}, 14-\mathrm{CH}), 6.73$ (apparent dt, $J=15.9,7.4 \mathrm{~Hz}, 1 \mathrm{H}$, 15-CH); ${ }^{13} \mathrm{C} \mathrm{NMR}\left(\mathrm{CDCl}_{3}, 101 \mathrm{MHz}\right) \delta 11.7\left(\mathrm{CH}_{3}\right), 12.1\left(\mathrm{CH}_{3}\right), 13.9\left(\mathrm{CH}_{3}\right), 20.6\left(\mathrm{CH}_{3}\right), 26.9\left(\mathrm{CH}_{3}\right), 30.4$ $(\mathrm{CH}), 31.8(\mathrm{CH}), 33.4(\mathrm{CH}), 37.4\left(\mathrm{CH}_{2}\right), 40.0\left(\mathrm{CH}_{2}\right), 63.3(\mathrm{CH}), 64.2\left(\mathrm{CH}_{2}\right), 74.7(\mathrm{CH}), 81.5(\mathrm{CH}), 89.2$ $(\mathrm{CH}), 93.5\left(\mathrm{CH}_{2}\right), 132.6(\mathrm{C}), 132.7(\mathrm{CH}), 135.3(\mathrm{CH}), 146.6(\mathrm{CH}), 199.0(\mathrm{C})$; IR $\vee 3420(\mathrm{w}), 2965(\mathrm{w})$, $1670(\mathrm{~m}), 1360$ (w), $1255(\mathrm{~m}), 1175(\mathrm{~m}), 1040(\mathrm{~s}), 980(\mathrm{~m}), 940(\mathrm{w}), 860(\mathrm{w}), 705(\mathrm{w}), 560(\mathrm{w}) \mathrm{cm}^{-1}$; HRMS (ESI): $\mathrm{m} / \mathrm{z}[\mathrm{M}+\mathrm{H}]^{+}$Calcd. for $\mathrm{C}_{21} \mathrm{H}_{36} \mathrm{ClO}_{5}$ : 403.22458; Found: 403.22456, m/z [M + Na] ${ }^{+}$Calcd. for $\mathrm{C}_{21} \mathrm{H}_{35} \mathrm{ClNaO}_{5}$ : 425.20652; Found: 425.20621 .

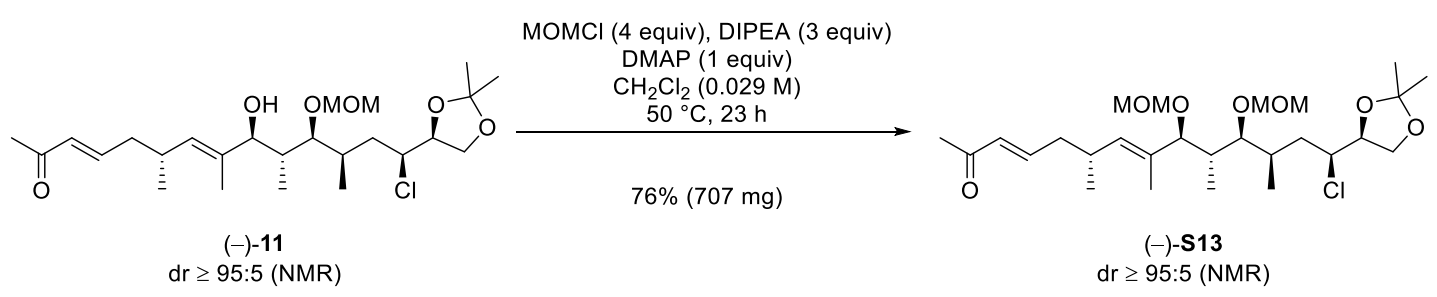

Bis(methoxymethyl) Ether (-)-S13. A sealable glass pressure tube was charged with enone (-)-11 $\left(\mathrm{C}_{25} \mathrm{H}_{43} \mathrm{ClO}_{6}, 475.06 \mathrm{~g} / \mathrm{mol}, 854 \mathrm{mg}, 1.8 \mathrm{mmol}, 1\right.$ equiv) in $\mathrm{CH}_{2} \mathrm{Cl}_{2}(63 \mathrm{~mL}, 0.029 \mathrm{M})$ to afford a colorless solution. Chloromethyl methyl ether $\left(\mathrm{MOMCl}, \mathrm{C}_{2} \mathrm{H}_{5} \mathrm{ClO}, 80.51 \mathrm{~g} / \mathrm{mol}, 1.06 \mathrm{~g} / \mathrm{mL}, 546 \mu \mathrm{L}, 579 \mathrm{mg}, 7.19\right.$ mmol, 4 equiv), $N, N$-diisopropylethylamine (DIPEA, $\mathrm{C}_{8} \mathrm{H}_{19} \mathrm{~N}, 129.25 \mathrm{~g} / \mathrm{mol}, 0.742 \mathrm{~g} / \mathrm{mL}, 939 \mu \mathrm{L}, 697$ $\mathrm{mg}, 5.39 \mathrm{mmol}, 3$ equiv), and 4-(dimethylamino)pyridine (DMAP, $\mathrm{C}_{7} \mathrm{H}_{10} \mathrm{~N}_{2}, 122.17 \mathrm{~g} / \mathrm{mol}, 220 \mathrm{mg}, 1.8$ mmol, 1 equiv) were added at ambient temperature to afford a colorless reaction mixture. The tube was sealed with a Teflon screw cap and placed in a pre-heated oil bath $\left(50{ }^{\circ} \mathrm{C}\right)$. After being stirred for $23 \mathrm{~h}$ at $50{ }^{\circ} \mathrm{C}$, the resulting orange reaction mixture was diluted by the addition of aqueous phosphate buffer $(\mathrm{pH}$ 7 ) at ambient temperature. The resulting orange biphasic mixture was transferred into a separatory funnel using $\mathrm{CH}_{2} \mathrm{Cl}_{2}$ for rinsing. The phases were separated, and the aqueous layer was extracted with $\mathrm{CH}_{2} \mathrm{Cl}_{2}$ $(4 \times)$. The combined organic layers were dried $\left(\mathrm{MgSO}_{4}\right)$. Removal of all volatiles under reduced pressure and subsequent purification of the remaining orange oil by flash chromatography (cyclohexane-ethyl acetate, 20:1 to 5:1) delivered (-)-S13 $\left(\mathrm{C}_{27} \mathrm{H}_{47} \mathrm{ClO}_{7}, 519.12 \mathrm{~g} / \mathrm{mol}, 707 \mathrm{mg}, 1.36 \mathrm{mmol}, 76 \%\right.$, dr $\geq 95: 5$ according to NMR evaluation) as a viscos colorless oil. $\mathrm{R}_{\mathrm{f}} 0.37$ (cyclohexane-ethyl acetate, $\left.2: 1\right) ;[\alpha]_{\mathrm{D}}{ }^{20}=$ $-36.8\left(c=1, \mathrm{CHCl}_{3}\right) ;{ }^{1} \mathrm{H} \mathrm{NMR}\left(\mathrm{CDCl}_{3}, 600 \mathrm{MHz}\right) \delta 0.78(\mathrm{~d}, J=7.3 \mathrm{~Hz}, 3 \mathrm{H}), 0.99(\mathrm{~d}, J=6.7 \mathrm{~Hz}, 3 \mathrm{H})$, $1.00(\mathrm{~d}, J=6.9 \mathrm{~Hz}, 3 \mathrm{H}), 1.37(\mathrm{~s}, 3 \mathrm{H}), 1.46(\mathrm{~s}, 3 \mathrm{H}), 1.50-1.57(\mathrm{~m}, 4 \mathrm{H}), 1.92(\mathrm{ddd}, J=14.4,9.2,2.9 \mathrm{~Hz}$, $1 \mathrm{H}), 2.05-2.13(\mathrm{~m}, 2 \mathrm{H}), 2.15-2.28(\mathrm{~m}, 5 \mathrm{H}), 2.57-2.65(\mathrm{~m}, 1 \mathrm{H}), 3.34(\mathrm{~s}, 3 \mathrm{H}), 3.38(\mathrm{~s}, 3 \mathrm{H}), 3.67(\mathrm{~d}, J=9.5$ $\mathrm{Hz}, 1 \mathrm{H}), 3.69(\mathrm{dd}, J=4.1,2.0 \mathrm{~Hz}, 1 \mathrm{H}), 3.88(\mathrm{dd}, J=8.5,6.5 \mathrm{~Hz}, 1 \mathrm{H}), 4.04-4.09$ (m, 2H), 4.24 (apparent $\mathrm{td}, J=6.5,5.3 \mathrm{~Hz}, 1 \mathrm{H}), 4.47(\mathrm{~d}, J=6.3 \mathrm{~Hz}, 1 \mathrm{H}), 4.52(\mathrm{~d}, J=6.2 \mathrm{~Hz}, 1 \mathrm{H}), 4.57(\mathrm{~d}, J=6.7 \mathrm{~Hz}, 1 \mathrm{H}), 4.59$ 
$(\mathrm{d}, J=6.8 \mathrm{~Hz}, 1 \mathrm{H}), 5.17(\mathrm{dd}, J=9.5,1.0 \mathrm{~Hz}, 1 \mathrm{H}), 6.06$ (apparent dt, $J=15.9,1.3, \mathrm{~Hz}, 1 \mathrm{H}), 6.74$ (apparent dt, $J=15.9,7.3 \mathrm{~Hz}, 1 \mathrm{H}) ;{ }^{13} \mathrm{C} \mathrm{NMR}\left(\mathrm{CDCl}_{3}, 151 \mathrm{MHz}\right) \delta 11.4\left(\mathrm{CH}_{3}\right), 12.6\left(\mathrm{CH}_{3}\right), 16.9\left(\mathrm{CH}_{3}\right)$, $20.9\left(\mathrm{CH}_{3}\right), 25.4\left(\mathrm{CH}_{3}\right), 26.3\left(\mathrm{CH}_{3}\right), 26.9\left(\mathrm{CH}_{3}\right), 30.6(\mathrm{CH}), 32.2(\mathrm{CH}), 39.0(\mathrm{CH}), 39.9\left(\mathrm{CH}_{2}\right), 40.3$ $\left(\mathrm{CH}_{2}\right), 55.8\left(\mathrm{CH}_{3}\right), 56.3\left(\mathrm{CH}_{3}\right), 61.5(\mathrm{CH}), 66.6\left(\mathrm{CH}_{2}\right), 78.8(\mathrm{CH}), 79.9(\mathrm{CH}), 85.6(\mathrm{CH}), 94.9\left(\mathrm{CH}_{2}\right), 96.9$ $\left(\mathrm{CH}_{2}\right), 110.0(\mathrm{C}), 132.5(\mathrm{CH}), 133.1(\mathrm{C}), 135.5(\mathrm{CH}), 146.8(\mathrm{CH}), 198.8(\mathrm{C})$; IR $\vee 2930(\mathrm{w}), 1675(\mathrm{~m})$, $1630(\mathrm{w}), 1455(\mathrm{w}), 1370(\mathrm{~m}), 1250(\mathrm{~m}), 1215(\mathrm{~m}), 1155(\mathrm{~m}), 1025(\mathrm{~s}), 920(\mathrm{~m}), 855(\mathrm{w}), 545(\mathrm{w}) \mathrm{cm}^{-1}$; Anal. Calcd. for $\mathrm{C}_{27} \mathrm{H}_{47} \mathrm{ClO}_{7}$ : C, 62.5; H, 9.1; Found: $\mathrm{C}, 62.5$; H, 9.2.
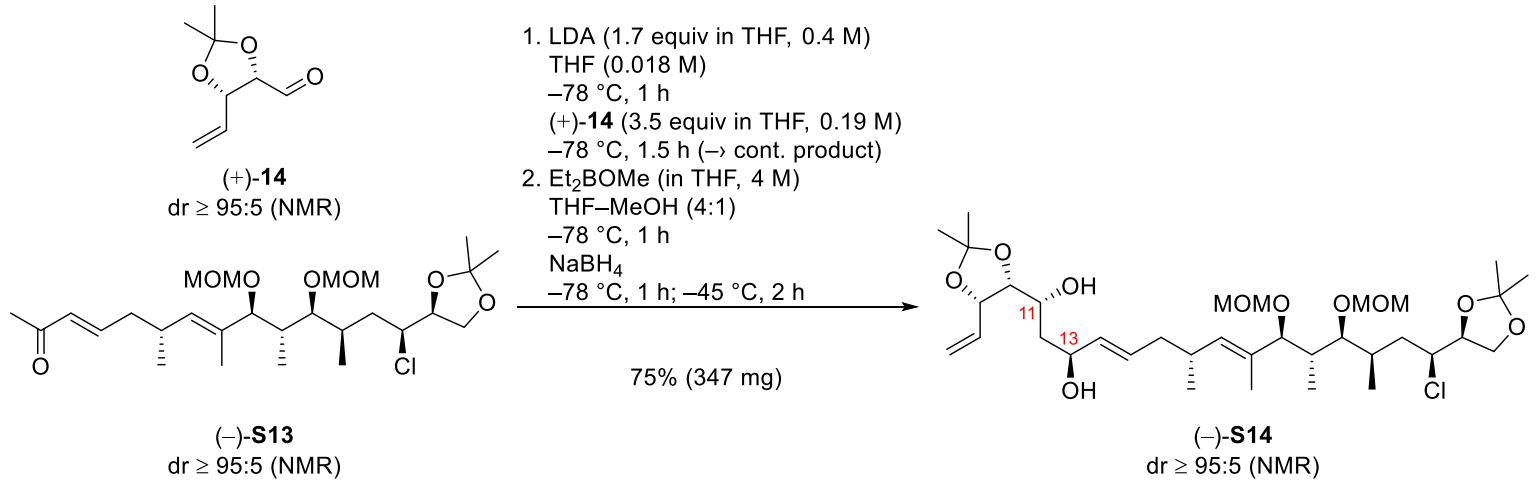

syn-11,13-Diol (-)-S14. To a stirred solution of diisopropylamine (DIPA, $\mathrm{C}_{6} \mathrm{H}_{15} \mathrm{~N}, 101.19 \mathrm{~g} / \mathrm{mol}, 0.722$ $\mathrm{g} / \mathrm{mL}, 570 \mu \mathrm{L}, 412 \mathrm{mg}, 4.07 \mathrm{mmol})$ in THF $(7.5 \mathrm{~mL})$ at $-78{ }^{\circ} \mathrm{C}$ was added $n$-butyllithium $\left(\mathrm{C}_{4} \mathrm{H}_{9} \mathrm{Li}, 2.5 \mathrm{M}\right.$ in $n$-hexane, $1.53 \mathrm{~mL}, 3.83 \mathrm{mmol}$ ) to afford a colorless solution. After being stirred for $5 \mathrm{~min}$ at $-78{ }^{\circ} \mathrm{C}$, the solution was warmed to $0{ }^{\circ} \mathrm{C}$ and stirring was continued at $0{ }^{\circ} \mathrm{C}$ for $30 \mathrm{~min}$. A part of the resulting lithium diisopropylamide solution (LDA, $\mathrm{C}_{6} \mathrm{H}_{14} \mathrm{LiN}$, assumed to be $0.4 \mathrm{M}$ in THF- $n$-hexane $\{5: 1\}$ ) was used immediately according to the following procedure: Bis(methoxymethyl) ether (-)-S13 $\left(\mathrm{C}_{27} \mathrm{H}_{47} \mathrm{ClO}_{7}\right.$, $519.12 \mathrm{~g} / \mathrm{mol}, 726 \mathrm{mg}, 1.4 \mathrm{mmol}, 1$ equiv) was dissolved in THF (79 mL, $0.018 \mathrm{M})$ and cooled to $-78{ }^{\circ} \mathrm{C}$. LDA $\left(\mathrm{C}_{6} \mathrm{H}_{14} \mathrm{LiN}\right.$, assumed to be $0.4 \mathrm{M}$ in THF- $n$-hexane $\{5: 1\}, 5.95 \mathrm{~mL}, 2.38 \mathrm{mmol}, 1.7$ equiv $)$ was added at $-78{ }^{\circ} \mathrm{C}$ to afford a colorless reaction mixture. After being stirred for $1 \mathrm{~h}$ at $-78{ }^{\circ} \mathrm{C}$, a solution of the freshly prepared aldehyde $(+)-\mathbf{1 4}\left(\mathrm{C}_{8} \mathrm{H}_{12} \mathrm{O}_{3}, 80 \% \mathrm{~m} / \mathrm{m}\right.$ in diethyl ether, $960 \mathrm{mg}$ containing $768 \mathrm{mg}(+)-$ 14, $156.18 \mathrm{~g} / \mathrm{mol}, 4.92 \mathrm{mmol}, 3.5$ equiv) in THF (26 mL, 0.19 M) (overall: $0.013 \mathrm{M}$ in (-)-S13 in THF) was added dropwise at $-78{ }^{\circ} \mathrm{C}$ to afford a colorless reaction mixture. After being stirred for $1.5 \mathrm{~h}$ at -78 ${ }^{\circ} \mathrm{C}$, the colorless solution was diluted by the slow addition of saturated aqueous $\mathrm{NH}_{4} \mathrm{Cl}$ solution at $-78{ }^{\circ} \mathrm{C}$. The resulting colorless biphasic mixture was transferred into a separatory funnel using diethyl ether for rinsing. The phases were separated, and the aqueous layer was extracted with $\mathrm{CH}_{2} \mathrm{Cl}_{2}(4 \times)$. The combined organic layers were dried $\left(\mathrm{MgSO}_{4}\right)$. Removal of all volatiles under reduced pressure and attempted purification of the colorless oil by flash chromatography (cyclohexane-ethyl acetate, 10:1 to 1:1) delivered a clear colorless oil ( $824 \mathrm{mg}$ ). NMR analysis revealed significant but inseparable impurities of unconsumed aldehyde (+)-14, and, to avoid decomposition due to extensive chromatography, the colorless oil was used without further purification.

Note: The reaction was carried out in parallel in two batches. To two stirred solutions of the colorless oil (400 mg [2×200 mg]; $48.5 \% \mathrm{~m} / \mathrm{m}$ of the total product) in THF $(48 \mathrm{~mL} \mathrm{[2 \times 24} \mathrm{mL])} \mathrm{and} \mathrm{methanol}(12 \mathrm{~mL}$ $[2 \times 6 \mathrm{~mL}])$ at $-78{ }^{\circ} \mathrm{C}$ was added diethylmethoxyborane $\left(\mathrm{Et}_{2} \mathrm{BOMe}, \mathrm{C}_{5} \mathrm{H}_{13} \mathrm{BO}, 4 \mathrm{M}\right.$ in THF, $592 \mu \mathrm{L}[2 \times 296$ $\mu \mathrm{L}], 2.37 \mathrm{mmol})$ to afford two colorless solutions. After being stirred for $1 \mathrm{~h}$ at $-78{ }^{\circ} \mathrm{C}$, sodium borohydride $\left(\mathrm{NaBH}_{4}, 37.83 \mathrm{~g} / \mathrm{mol}, 112 \mathrm{mg}\right.$ [2×56 mg], $\left.2.96 \mathrm{mmol}\right)$ was added at $-78{ }^{\circ} \mathrm{C}$ to both solutions to afford two colorless reaction mixtures. After being stirred for $1 \mathrm{~h}$ at $-78{ }^{\circ} \mathrm{C}$ and subsequently $2 \mathrm{~h}$ at -45 ${ }^{\circ} \mathrm{C}$, the two colorless solutions were diluted by the addition of aqueous phosphate buffer $(\mathrm{pH} 7,40 \mathrm{~mL}$ $[2 \times 20 \mathrm{~mL}])$, methanol $(40 \mathrm{~mL}[2 \times 20 \mathrm{~mL}])$, and hydrogen peroxide $(35 \% \mathrm{~m} / \mathrm{m}$ in water, $20 \mathrm{~mL}[2 \times 10$ $\mathrm{mL}])$ at $-78{ }^{\circ} \mathrm{C}$. The two colorless biphasic mixtures were allowed to warm to ambient temperature and were immediately transferred into a single beaker using $\mathrm{CH}_{2} \mathrm{Cl}_{2}$ for rinsing. The colorless biphasic mixture was diluted by the very slow addition of saturated aqueous $\mathrm{Na}_{2} \mathrm{~S}_{2} \mathrm{O}_{3}$ solution $(80 \mathrm{~mL})$ at $0{ }^{\circ} \mathrm{C}$. The resulting colorless biphasic mixture was transferred into a separatory funnel using $\mathrm{CH}_{2} \mathrm{Cl}_{2}$ for rinsing. The phases were separated, and the aqueous layer was extracted with $\mathrm{CH}_{2} \mathrm{Cl}_{2}(5 \times)$. The combined organic 
layers were dried $\left(\mathrm{MgSO}_{4}\right)$. Removal of all volatiles under reduced pressure and subsequent purification of the remaining colorless oil by flash chromatography (cyclohexane-ethyl acetate, 5:1 to 1:2) delivered (-)-S14 $\left(\mathrm{C}_{35} \mathrm{H}_{61} \mathrm{ClO}_{10}, 677.31 \mathrm{~g} / \mathrm{mol}, 347 \mathrm{mg}, 512 \mu \mathrm{mol}, 75 \%\right.$ considering that $48.5 \% \mathrm{~m} / \mathrm{m}$ of the total product from the aldol reaction were used, $\mathrm{dr} \geq 95: 5$ according to NMR evaluation) as a viscos colorless oil. The absolute configuration of 11- $\mathrm{CH}$ and 13-CH was tentatively assigned and later confirmed by the configurational correlation method of Mosher and the ${ }^{13} \mathrm{C}$ NMR acetonide analysis of Rychnovsky. $\mathrm{R}_{\mathrm{f}}$ 0.37 (cyclohexane-ethyl acetate, $1: 1) ;[\alpha]_{\mathrm{D}}{ }^{20}=-11.2\left(c=1, \mathrm{CHCl}_{3}\right) ;{ }^{1} \mathrm{H} \mathrm{NMR}\left(\mathrm{CDCl}_{3}, 400 \mathrm{MHz}\right) \delta 0.77$ $(\mathrm{d}, J=7.1 \mathrm{~Hz}, 3 \mathrm{H}), 0.94(\mathrm{~d}, J=6.7 \mathrm{~Hz}, 3 \mathrm{H}), 1.00(\mathrm{~d}, J=6.8 \mathrm{~Hz}, 3 \mathrm{H}), 1.36(\mathrm{~s}, 3 \mathrm{H}), 1.37(\mathrm{~s}, 3 \mathrm{H}), 1.45(\mathrm{~s}$, $3 \mathrm{H}), 1.46(\mathrm{~s}, 3 \mathrm{H}), 1.50(\mathrm{~s}, 3 \mathrm{H}), 1.51-1.64(\mathrm{~m}, 2 \mathrm{H}), 1.80-1.97(\mathrm{~m}, 3 \mathrm{H}), 2.03-2.20(\mathrm{~m}, 3 \mathrm{H}), 2.45-2.58(\mathrm{~m}$, $1 \mathrm{H}), 3.35$ (s, $3 \mathrm{H}), 3.38(\mathrm{~s}, 3 \mathrm{H}), 3.64-3.71(\mathrm{~m}, 2 \mathrm{H}), 3.76$ (br. s, $1 \mathrm{H}), 3.83-3.90(\mathrm{~m}, 2 \mathrm{H}), 3.95(\mathrm{dd}, J=8.5$, $6.2 \mathrm{~Hz}, 1 \mathrm{H}), 3.99-4.09(\mathrm{~m}, 3 \mathrm{H}), 4.21-4.28(\mathrm{~m}, 2 \mathrm{H}), 4.50-4.59(\mathrm{~m}, 3 \mathrm{H}), 4.65-4.71(\mathrm{~m}, 2 \mathrm{H}), 5.07(\mathrm{~d}, J=$ $9.7 \mathrm{~Hz}, 1 \mathrm{H}), 5.27(\mathrm{~d}, J=10.4 \mathrm{~Hz}, 1 \mathrm{H}), 5.37-5.47(\mathrm{~m}, 3 \mathrm{H}), 6.07(\mathrm{ddd}, J=17.1,10.4,6.7 \mathrm{~Hz}, 1 \mathrm{H}) ;{ }^{13} \mathrm{C}$ NMR $\left(\mathrm{CDCl}_{3}, 101 \mathrm{MHz}\right) \delta 11.1\left(\mathrm{CH}_{3}\right), 12.8\left(\mathrm{CH}_{3}\right), 16.9\left(\mathrm{CH}_{3}\right), 21.2\left(\mathrm{CH}_{3}\right), 25.4\left(\mathrm{CH}_{3}\right), 25.6\left(\mathrm{CH}_{3}\right), 26.4$ $\left(\mathrm{CH}_{3}\right), 27.9\left(\mathrm{CH}_{3}\right), 30.7(\mathrm{CH}), 32.5(\mathrm{CH}), 38.4(\mathrm{CH}), 39.6\left(\mathrm{CH}_{2}\right), 40.2\left(\mathrm{CH}_{2}\right), 40.3\left(\mathrm{CH}_{2}\right), 55.9\left(\mathrm{CH}_{3}\right)$, $56.0\left(\mathrm{CH}_{3}\right), 61.3(\mathrm{CH}), 66.6\left(\mathrm{CH}_{2}\right), 70.9(\mathrm{CH}), 74.2(\mathrm{CH}), 78.7(\mathrm{CH}), 79.0(\mathrm{CH}), 79.9(\mathrm{CH}), 80.8(\mathrm{CH})$, $86.7(\mathrm{CH}), 94.4\left(\mathrm{CH}_{2}\right), 96.9\left(\mathrm{CH}_{2}\right), 108.6(\mathrm{C}), 110.0(\mathrm{C}), 117.6\left(\mathrm{CH}_{2}\right), 130.5(\mathrm{CH}), 131.6(\mathrm{C}), 134.1(\mathrm{CH})$, $134.8(\mathrm{CH}), 137.3(\mathrm{CH})$; IR $\vee 2925(\mathrm{w}), 1740(\mathrm{w}), 1455(\mathrm{w}), 1370(\mathrm{~m}), 1245(\mathrm{~m}), 1215(\mathrm{~m}), 1155(\mathrm{~m})$, 1030 (s), $920(\mathrm{~m}), 875(\mathrm{~m}), 515(\mathrm{w}) \mathrm{cm}^{-1}$; Anal. Calcd. for $\mathrm{C}_{35} \mathrm{H}_{61} \mathrm{ClO}_{10}$ : C, 62.1; H, 9.1; Found: C, 62.0; $\mathrm{H}, 9.3$.

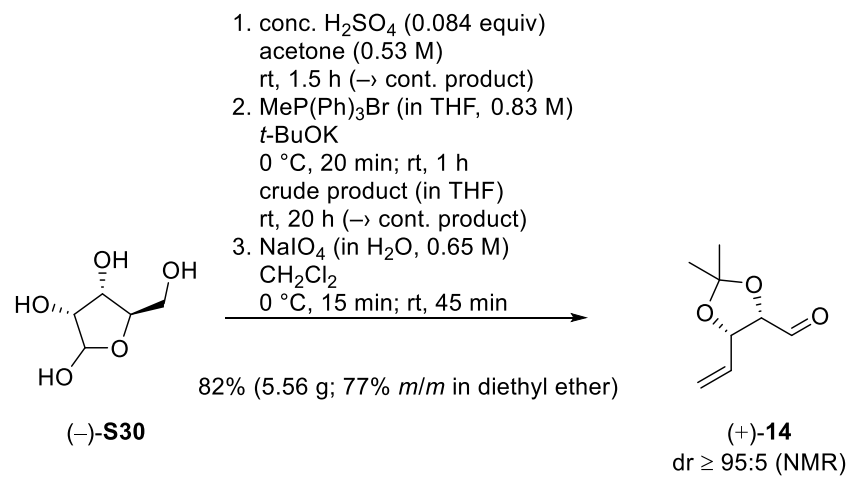

Aldehyde (+)-14. ${ }^{18}$ Note: Slightly modified and optimized procedure. To a stirred suspension of $D-(-)-$ ribose $\mathbf{S 3 0}\left(\mathrm{C}_{5} \mathrm{H}_{10} \mathrm{O}_{5}, 150.13 \mathrm{~g} / \mathrm{mol}, 20 \mathrm{~g}, 133.22 \mathrm{mmol}, 1\right.$ equiv) in acetone $(250 \mathrm{~mL}, 0.53 \mathrm{M})$ at ambient temperature was added concentrated sulfuric acid $\left(\mathrm{H}_{2} \mathrm{SO}_{4}, 98.08 \mathrm{~g} / \mathrm{mol}, 1.84 \mathrm{~g} / \mathrm{mL}, 598 \mu \mathrm{L}, 1.1 \mathrm{~g}, 11.22\right.$ mmol, 0.084 equiv) to afford a yellow suspension. After being stirred for $1.5 \mathrm{~h}$ at ambient temperature, solid $\mathrm{KHCO}_{3}$ was added till no more gas formation was observed. The yellow white suspension was filtered, and the solid white residue was washed with acetone $(3 \times)$. The filtrate was concentrated under reduced pressure and attempted purification of the yellow oil by flash chromatography (cyclohexaneethyl acetate, 10:1 to 1:1) delivered a colorless oil (20.27 g). NMR analysis revealed significant but inseparable impurities, and the colorless oil was used without further purification.

To a stirred solution of methyltriphenylphosphonium bromide $\left(\mathrm{C}_{19} \mathrm{H}_{18} \mathrm{BrP}, 357.22 \mathrm{~g} / \mathrm{mol}, 106.63 \mathrm{~g}, 298.5\right.$ $\mathrm{mmol})$ in THF $(359 \mathrm{~mL}, 0.83 \mathrm{M})$ at $0{ }^{\circ} \mathrm{C}$ was added potassium tert-butoxide $\left(\mathrm{C}_{4} \mathrm{H}_{9} \mathrm{KO}, 112.21 \mathrm{~g} / \mathrm{mol}\right.$, $35.88 \mathrm{~g}, 319.76 \mathrm{mmol}$ ) to afford a slightly yellow solution. After being stirred for $20 \mathrm{~min}$ at $0{ }^{\circ} \mathrm{C}$ and, after removal of the cooling bath, subsequently $1 \mathrm{~h}$ at ambient temperature, a solution of the colorless oil from above $(20.27 \mathrm{~g})$ in THF $(233 \mathrm{~mL})$ was added at $0{ }^{\circ} \mathrm{C}$ to afford a yellow reaction mixture. The cooling bath was removed, and stirring was continued for $20 \mathrm{~h}$ at ambient temperature. The yellow reaction mixture was diluted by the addition of water at ambient temperature. The resulting yellow biphasic mixture was transferred into a separatory funnel using diethyl ether for rinsing. The phases were separated, and the aqueous layer was extracted with $\mathrm{CH}_{2} \mathrm{Cl}_{2}(3 \times)$. The combined organic layers were dried $\left(\mathrm{MgSO}_{4}\right)$. Removal of all volatiles under reduced pressure and attempted purification of the yellow oil by flash chromatography (cyclohexane-ethyl acetate, 50:1 to 1:1) delivered a viscous yellow oil (71.24 g). NMR analysis revealed significant but inseparable impurities of triphenylphosphine $\left(\mathrm{Ph}_{3} \mathrm{PO}\right)$, and the 
viscous yellow oil was used without further purification.

To a stirred solution of the viscous yellow oil $(17.81 \mathrm{~g} ; 25 \% \mathrm{~m} / \mathrm{m}$ of the total product, contaminated with $\left.\mathrm{Ph}_{3} \mathrm{PO}\right)$ in $\mathrm{CH}_{2} \mathrm{Cl}_{2}(132 \mathrm{~mL})$ at $0{ }^{\circ} \mathrm{C}$ was added sodium periodate $\left(\mathrm{NaIO}_{4}, 213.89 \mathrm{~g} / \mathrm{mol}, 9.43 \mathrm{~g}, 44.09\right.$ $\mathrm{mmol})$ dissolved in water $(68 \mathrm{~mL}, 0.65 \mathrm{M})$ to afford a slightly yellow biphasic mixture. After being stirred for $15 \mathrm{~min}$ at $0{ }^{\circ} \mathrm{C}$ and, after removal of the cooling bath, subsequently $45 \mathrm{~min}$ at ambient temperature, the slightly yellow biphasic mixture was diluted by the addition of water and $\mathrm{CH}_{2} \mathrm{Cl}_{2}(v / v=1: 1)$ at ambient temperature. The slightly yellow biphasic mixture was transferred into a separatory funnel using $\mathrm{CH}_{2} \mathrm{Cl}_{2}$ for rinsing. The phases were separated, and the aqueous layer was extracted with $\mathrm{CH}_{2} \mathrm{Cl}_{2}(3 \times)$. The combined organic layers were dried $\left(\mathrm{MgSO}_{4}\right)$. Removal of volatiles under reduced pressure $\left(40{ }^{\circ} \mathrm{C}, 600\right.$ mbar) delivered a slightly yellow oil. Purification of the slightly yellow oil by flash chromatography $(n-$ pentane-diethyl ether, 10:1 to 2:1) and subsequent removal of volatiles under reduced pressure $\left(40{ }^{\circ} \mathrm{C}\right.$, $500 \mathrm{mbar})$ to a final volume of $5 \mathrm{~mL}$ delivered a colorless solution $(5.56 \mathrm{~g}) .{ }^{1} \mathrm{H}$ NMR examination of an aliquot revealed that the colorless solution consisted of diethyl ether and volatile $(+)-\mathbf{1 4}\left(\mathrm{C}_{8} \mathrm{H}_{12} \mathrm{O}_{3}, 77 \%\right.$ $\mathrm{m} / \mathrm{m}$ in diethyl ether, $5.56 \mathrm{~g}$ containing $4.28 \mathrm{~g}(+)-14,156.18 \mathrm{~g} / \mathrm{mol}, 27.4 \mathrm{mmol}, 82 \%$ considering that $25 \% \mathrm{~m} / \mathrm{m}$ of the total product from the Wittig reaction were used, dr $\geq 95: 5$ according to NMR evaluation). The solution was used without further purification. $\mathrm{R}_{\mathrm{f}} 0.14$ (cyclohexane-ethyl acetate, 5:1); $[\alpha]_{\mathrm{D}}{ }^{20}=+0.6\left(c=1, \mathrm{CHCl}_{3}\right) ;{ }^{1} \mathrm{H} \mathrm{NMR}\left(\mathrm{CDCl}_{3}, 500 \mathrm{MHz}\right) \delta 1.44(\mathrm{~s}, 3 \mathrm{H}), 1.63(\mathrm{~s}, 3 \mathrm{H}), 4.42(\mathrm{dd}, J=7.5$, $3.1 \mathrm{~Hz}, 1 \mathrm{H}$ ), 4.86 (apparent t, $J=7.3 \mathrm{~Hz}, 1 \mathrm{H}$ ), 5.33 (apparent dt, $J=10.4,1.2 \mathrm{~Hz}, 1 \mathrm{H}$ ), 5.47 (apparent dt, $J=17.1,1.3 \mathrm{~Hz}, 1 \mathrm{H}), 5.76(\mathrm{ddd}, J=17.1,10.3,7.0 \mathrm{~Hz}, 1 \mathrm{H}), 9.56(\mathrm{~d}, J=3.1 \mathrm{~Hz}, 1 \mathrm{H}) ;{ }^{13} \mathrm{C} \mathrm{NMR}\left(\mathrm{CDCl}_{3}\right.$, $126 \mathrm{MHz}) \delta 25.5\left(\mathrm{CH}_{3}\right), 27.5\left(\mathrm{CH}_{3}\right), 79.2(\mathrm{CH}), 82.4(\mathrm{CH}), 111.4(\mathrm{C}), 120.0\left(\mathrm{CH}_{2}\right), 131.3(\mathrm{CH}), 200.9$ $(\mathrm{CH}) ; \mathrm{IR} \vee 2990(\mathrm{w}), 2940(\mathrm{w}), 1735(\mathrm{~s}), 1455(\mathrm{w}), 1430(\mathrm{w}), 1375(\mathrm{~s}), 1245(\mathrm{~m}), 1215(\mathrm{~s}), 1160(\mathrm{~m})$, $1110(\mathrm{~m}), 1060$ (s), 1015 (m), $990(\mathrm{~m}), 935$ (m), 870 (s), 795 (w), $640(\mathrm{w}), 515(\mathrm{w}) \mathrm{cm}^{-1}$. Our analytical data matched those reported in the literature.
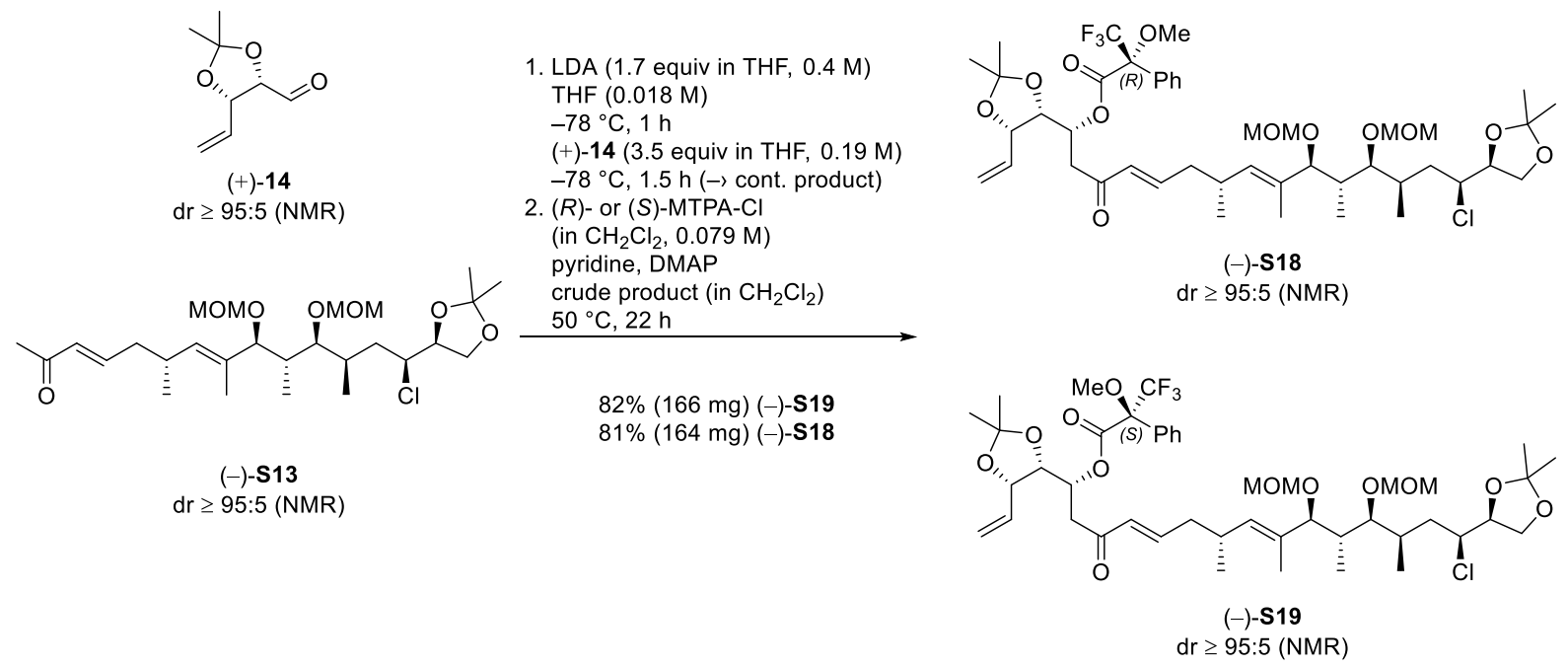

$(S)$ - and $(R)$-Mosher Ester (-)-S19 and (-)-S18. To a stirred solution of diisopropylamine (DIPA, $\left.\mathrm{C}_{6} \mathrm{H}_{15} \mathrm{~N}, 101.19 \mathrm{~g} / \mathrm{mol}, 0.722 \mathrm{~g} / \mathrm{mL}, 570 \mu \mathrm{L}, 412 \mathrm{mg}, 4.07 \mathrm{mmol}\right)$ in THF $(7.5 \mathrm{~mL})$ at $-78{ }^{\circ} \mathrm{C}$ was added $n$-butyllithium $\left(\mathrm{C}_{4} \mathrm{H}_{9} \mathrm{Li}, 2.5 \mathrm{M}\right.$ in $n$-hexane, $\left.1.53 \mathrm{~mL}, 3.83 \mathrm{mmol}\right)$ to afford a colorless solution. After being stirred for $5 \mathrm{~min}$ at $-78{ }^{\circ} \mathrm{C}$, the solution was warmed to $0{ }^{\circ} \mathrm{C}$ and stirring was continued at $0{ }^{\circ} \mathrm{C}$ for $30 \mathrm{~min}$. A part of the resulting lithium diisopropylamide solution (LDA, $\mathrm{C}_{6} \mathrm{H}_{14} \mathrm{LiN}$, assumed to be $0.4 \mathrm{M}$ in THF- $n$-hexane $\{5: 1\})$ was used immediately according to the following procedure: Bis(methoxymethyl) ether (-)-S13 $\left(\mathrm{C}_{27} \mathrm{H}_{47} \mathrm{ClO}_{7}, 519.12 \mathrm{~g} / \mathrm{mol}, 726 \mathrm{mg}, 1.4 \mathrm{mmol}, 1\right.$ equiv) was dissolved in THF $(79 \mathrm{~mL}, 0.018 \mathrm{M})$ and cooled to $-78{ }^{\circ} \mathrm{C}$. LDA $\left(\mathrm{C}_{6} \mathrm{H}_{14} \mathrm{LiN}\right.$, assumed to be $0.4 \mathrm{M}$ in $\mathrm{THF}-n$-hexane $\{5: 1\}, 5.95 \mathrm{~mL}, 2.38 \mathrm{mmol}, 1.7$ equiv) was added at $-78{ }^{\circ} \mathrm{C}$ to afford a colorless reaction mixture. After being stirred for $1 \mathrm{~h}$ at $-78{ }^{\circ} \mathrm{C}$, a solution of the freshly prepared aldehyde $(+)-14\left(\mathrm{C}_{8} \mathrm{H}_{12} \mathrm{O}_{3}, 80 \% \mathrm{~m} / \mathrm{m}\right.$ in diethyl ether, $960 \mathrm{mg}$ containing $768 \mathrm{mg}(+)-14,156.18 \mathrm{~g} / \mathrm{mol}, 4.92 \mathrm{mmol}, 3.5$ equiv) in THF (26 mL, $0.19 \mathrm{M}$ ) (overall: $0.013 \mathrm{M}$ in (-)-S13 in THF) was added dropwise at $-78{ }^{\circ} \mathrm{C}$ to afford a colorless reaction mixture. After being stirred for $1.5 \mathrm{~h}$ at $-78{ }^{\circ} \mathrm{C}$, the colorless solution was diluted by the slow addition of 
saturated aqueous $\mathrm{NH}_{4} \mathrm{Cl}$ solution at $-78{ }^{\circ} \mathrm{C}$. The resulting colorless biphasic mixture was transferred into a separatory funnel using diethyl ether for rinsing. The phases were separated, and the aqueous layer was extracted with $\mathrm{CH}_{2} \mathrm{Cl}_{2}(4 \times)$. The combined organic layers were dried $\left(\mathrm{MgSO}_{4}\right)$. Removal of all volatiles under reduced and attempted purification of the colorless oil by flash chromatography (cyclohexane-ethyl acetate, 10:1 to 1:1) delivered a clear colorless oil $(824 \mathrm{mg})$. NMR analysis revealed significant but inseparable impurities of unconsumed aldehyde (+)-14, and, to avoid further decomposition during chromatography, the colorless oil was used without further purification.

Note: The reaction was carried out in parallel in two batches. Two sealable glass pressure tubes were charged with $(R)$-(-)- $\alpha$-methoxy- $\alpha$-(trifluoromethyl)phenylacetyl chloride $((R)-(-)$-MTPA-Cl, $\left.\mathrm{C}_{10} \mathrm{H}_{8} \mathrm{ClF}_{3} \mathrm{O}_{2}, 252.62 \mathrm{~g} / \mathrm{mol}, 1.35 \mathrm{~g} / \mathrm{mL}, 148 \mu \mathrm{L}[2 \times 74 \mu \mathrm{L}], 200 \mathrm{mg}[2 \times 100 \mathrm{mg}], 792 \mu \mathrm{mol}\right)$ in $\mathrm{CH}_{2} \mathrm{Cl}_{2}$ $(10 \mathrm{~mL}[2 \times 5 \mathrm{~mL}], 0.079 \mathrm{M})$ to afford two colorless solutions. Pyridine $\left(\mathrm{C}_{5} \mathrm{H}_{5} \mathrm{~N}, 79.1 \mathrm{~g} / \mathrm{mol}, 0.98 \mathrm{~g} / \mathrm{mL}\right.$, $241 \mu \mathrm{L}[2 \times 120.5 \mu \mathrm{L}], 236 \mathrm{mg}[2 \times 118 \mathrm{mg}], 2.98 \mathrm{mmol}$ ), 4-(dimethylamino)pyridine (DMAP, $\mathrm{C}_{7} \mathrm{H}_{10} \mathrm{~N}_{2}$, $122.17 \mathrm{~g} / \mathrm{mol}, 72 \mathrm{mg}[2 \times 36 \mathrm{mg}], 589 \mu \mathrm{mol})$ and, a solution of the colorless oil from above $(134 \mathrm{mg}$ [ $2 \times 67$ $\mathrm{mg}] ; 16.3 \% \mathrm{~m} / \mathrm{m}$ of the total product $)$ in $\mathrm{CH}_{2} \mathrm{Cl}_{2}(10 \mathrm{~mL}$ [2×5 mL]) was added at ambient temperature to both solutions to afford two slightly yellow solutions. The tubes were sealed with a Teflon screw cap and placed in a pre-heated oil bath $\left(50{ }^{\circ} \mathrm{C}\right)$. After being stirred for $22 \mathrm{~h}$ at $50{ }^{\circ} \mathrm{C}$, the resulting two yellow reaction mixtures were diluted by the addition of saturated aqueous $\mathrm{NH}_{4} \mathrm{Cl}$ solution at ambient temperature. The resulting two slightly yellow biphasic mixtures were transferred into a single separatory funnel using $\mathrm{CH}_{2} \mathrm{Cl}_{2}$ for rinsing. The phases were separated, and the aqueous layer was extracted with $\mathrm{CH}_{2} \mathrm{Cl}_{2}(4 \times)$. The combined organic layers were dried $\left(\mathrm{MgSO}_{4}\right)$. Removal of all volatiles under reduced pressure and subsequent purification of the remaining slightly yellow oil by flash chromatography (cyclohexane-ethyl acetate, 20:1 to 5:1) delivered (-)-S19 $\left(\mathrm{C}_{45} \mathrm{H}_{66} \mathrm{ClF}_{3} \mathrm{O}_{12}, 891.46 \mathrm{~g} / \mathrm{mol}, 166 \mathrm{mg}, 186\right.$ $\mu \mathrm{mol}, 82 \%$ considering that $16.3 \% \mathrm{~m} / \mathrm{m}$ of the total product from the aldol reaction were used, $\mathrm{dr} \geq 95: 5$ according to NMR evaluation) as a viscous colorless oil. $\mathrm{R}_{\mathrm{f}} 0.51$ (cyclohexane-ethyl acetate, $2: 1$ ); $[\alpha]_{\mathrm{D}}{ }^{25}$ $=-39.9\left(c=1, \mathrm{CHCl}_{3}\right) ;{ }^{1} \mathrm{H} \mathrm{NMR}\left(\mathrm{CDCl}_{3}, 600 \mathrm{MHz}\right) \delta 0.77\left(\mathrm{~d}, J=7.3 \mathrm{~Hz}, 3 \mathrm{H}, 21^{\prime}-\mathrm{CH}_{3}\right), 0.97(\mathrm{~d}, J=6.7$ $\left.\mathrm{Hz}, 3 \mathrm{H}, 17^{\prime}-\mathrm{CH}_{3}\right), 1.00\left(\mathrm{~d}, J=6.9 \mathrm{~Hz}, 3 \mathrm{H}, 23^{\prime}-\mathrm{CH}_{3}\right), 1.31$ (s, 3H, acetonide- $\left.\mathrm{CH}_{3}\right), 1.37$ (s, 3H, acetonide$\left.\mathrm{CH}_{3}\right), 1.43\left(\mathrm{~s}, 3 \mathrm{H}\right.$, acetonide- $\left.\mathrm{CH}_{3}\right), 1.45\left(\mathrm{~s}, 3 \mathrm{H}\right.$, acetonide- $\left.\mathrm{CH}_{3}\right), 1.50-1.56\left(\mathrm{~m}, 4 \mathrm{H}, 19\right.$ '- $\left.\mathrm{CH}_{3}+24-\mathrm{CH}_{2}\right)$, 1.92 (ddd, $\left.J=14.4,9.2,2.8 \mathrm{~Hz}, 1 \mathrm{H}, 24-\mathrm{CH}_{2}\right), 2.04-2.13$ (m, 2H, 21-CH+23-CH), 2.15-2.24 (m, 2H, 16$\mathrm{CH}_{2}$ ), 2.58 (apparent dsxt, $\left.J=9.2,7.0 \mathrm{~Hz}, 1 \mathrm{H}, 17-\mathrm{CH}\right), 2.89$ (dd, $\left.J=17.3,3.5 \mathrm{~Hz}, 1 \mathrm{H}, 12-\mathrm{CH}_{2}\right), 3.03(\mathrm{dd}$, $\left.J=17.4,7.4 \mathrm{~Hz}, 1 \mathrm{H}, 12-\mathrm{CH}_{2}\right), 3.30\left(\mathrm{~s}, 3 \mathrm{H}, \mathrm{MOM}_{-} \mathrm{CH}_{3}\right), 3.38\left(\mathrm{~s}, 3 \mathrm{H}, \mathrm{MOM}-\mathrm{CH}_{3}\right), 3.49\left(\mathrm{~s}, 3 \mathrm{H},-\mathrm{OCH}_{3}\right)$, $3.66(\mathrm{~d}, J=9.6 \mathrm{~Hz}, 1 \mathrm{H}, 20-\mathrm{CH}), 3.68(\mathrm{dd}, J=4.1,2.0 \mathrm{~Hz}, 1 \mathrm{H}, 22-\mathrm{CH}), 3.88(\mathrm{dd}, J=8.5,6.5 \mathrm{~Hz}, 1 \mathrm{H}, 27-$ $\left.\mathrm{CH}_{2}\right), 4.04-4.08\left(\mathrm{~m}, 2 \mathrm{H}, 25-\mathrm{CH}+27-\mathrm{CH}_{2}\right), 4.24$ (apparent td, $\left.J=6.5,5.3 \mathrm{~Hz}, 1 \mathrm{H}, 26-\mathrm{CH}\right), 4.41(\mathrm{dd}, J=$ $6.8,5.4 \mathrm{~Hz}, 1 \mathrm{H}, 10-\mathrm{CH}), 4.43\left(\mathrm{~d}, J=6.3 \mathrm{~Hz}, 1 \mathrm{H}, \mathrm{MOM}_{-} \mathrm{CH}_{2}\right), 4.49\left(\mathrm{~d}, J=6.3 \mathrm{~Hz}, 1 \mathrm{H}, \mathrm{MOM}-\mathrm{CH}_{2}\right), 4.57$ $\left(\mathrm{d}, J=6.7 \mathrm{~Hz}, 1 \mathrm{H}, \mathrm{MOM}-\mathrm{CH}_{2}\right), 4.64$ (apparent tt, $\left.J=6.7,1.1 \mathrm{~Hz}, 1 \mathrm{H}, 9-\mathrm{CH}\right), 4.69(\mathrm{~d}, J=6.8 \mathrm{~Hz}, 1 \mathrm{H}$, MOM-CH 2 ), 5.12 (apparent dt, $J=10.5,1.3 \mathrm{~Hz}, 1 \mathrm{H}, 8^{\prime}-\mathrm{CH}_{2}$ ), 5.15 (dd, $\left.J=9.5,1.1 \mathrm{~Hz}, 1 \mathrm{H}, 18-\mathrm{CH}\right), 5.33$ (apparent dt, $\left.J=17.1,1.4 \mathrm{~Hz}, 1 \mathrm{H}, 8^{\prime}-\mathrm{CH}_{2}\right), 5.50$ (ddd, $\left.J=7.4,5.3,3.6 \mathrm{~Hz}, 1 \mathrm{H}, 11-\mathrm{CH}\right), 5.67$ (ddd, $J=$ 17.1, 10.4, $6.6 \mathrm{~Hz}, 1 \mathrm{H}, 8-\mathrm{CH}$ ), 6.09 (apparent dt, $J=15.8,1.3 \mathrm{~Hz}, 1 \mathrm{H}, 14-\mathrm{CH}$ ), 6.76 (apparent dt, $J=$

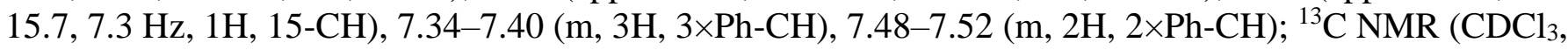
$151 \mathrm{MHz}) \delta 11.3\left(\mathrm{CH}_{3}\right), 12.6\left(\mathrm{CH}_{3}\right), 16.9\left(\mathrm{CH}_{3}\right), 20.8\left(\mathrm{CH}_{3}\right), 25.0\left(\mathrm{CH}_{3}\right), 25.4\left(\mathrm{CH}_{3}\right), 26.3\left(\mathrm{CH}_{3}\right), 27.1$ $\left(\mathrm{CH}_{3}\right), 30.6(\mathrm{CH}), 32.1(\mathrm{CH}), 38.9(\mathrm{CH}), 39.9\left(\mathrm{CH}_{2}\right), 40.2\left(\mathrm{CH}_{2}\right), 40.3\left(\mathrm{CH}_{2}\right), 55.6\left(\mathrm{CH}_{3}\right), 55.8\left(\mathrm{CH}_{3}\right)$, $56.2\left(\mathrm{CH}_{3}\right), 61.5(\mathrm{CH}), 66.6\left(\mathrm{CH}_{2}\right), 71.7(\mathrm{CH}), 77.7(\mathrm{CH}), 78.0(\mathrm{CH}), 78.8(\mathrm{CH}), 79.9(\mathrm{CH}), 84.2(\mathrm{q}, J=$ $27.6 \mathrm{~Hz}, \mathrm{C}), 85.5(\mathrm{CH}), 94.8\left(\mathrm{CH}_{2}\right), 96.8\left(\mathrm{CH}_{2}\right), 109.0(\mathrm{C}), 110.0(\mathrm{C}), 119.1\left(\mathrm{CH}_{2}\right), 123.3(\mathrm{q}, J=288.3$ $\mathrm{Hz}, \mathrm{C}), 127.6(\mathrm{CH}), 128.4(\mathrm{CH}), 129.7(\mathrm{CH}), 131.4(\mathrm{CH}), 132.1(\mathrm{C}), 132.4(\mathrm{CH}), 133.0(\mathrm{C}), 135.5(\mathrm{CH})$, $146.5(\mathrm{CH}), 165.8(\mathrm{C}), 195.8(\mathrm{C}) ;{ }^{19} \mathrm{~F} \mathrm{NMR}\left(\mathrm{CDCl}_{3}, 565 \mathrm{MHz}\right) \delta-71.4$; IR $\vee 2930(\mathrm{w}), 1745(\mathrm{~m}), 1675$ (w), $1630(\mathrm{w}), 1455(\mathrm{w}), 1375(\mathrm{~m}), 1255(\mathrm{~m}), 1215(\mathrm{~m}), 1165$ (s), $1025(\mathrm{~s}), 920(\mathrm{~m}), 855(\mathrm{~m}), 765(\mathrm{w})$, $720(\mathrm{~m}), 515(\mathrm{w}) \mathrm{cm}^{-1}$; HRMS (ESI): $\mathrm{m} / \mathrm{z}[\mathrm{M}+\mathrm{Na}]^{+}$Calcd. for $\mathrm{C}_{45} \mathrm{H}_{66} \mathrm{ClF}_{3} \mathrm{NaO}_{12}$ : 913.40871; Found: 913.40864.

In analogy to the procedure for the preparation of the $(S)$-Mosher Ester (-)-S19, the colorless oil from above $\left(134 \mathrm{mg}\right.$ [2×67 mg]; $16.3 \% \mathrm{~m} / \mathrm{m}$ of the total product) in $\mathrm{CH}_{2} \mathrm{Cl}_{2}(10 \mathrm{~mL}$ [2×5 mL]) was treated with $(S)$-(-)- $\alpha$-methoxy- $\alpha$-(trifluoromethyl)phenylacetyl chloride $\left((S)-(-)-\mathrm{MTPA}-\mathrm{Cl}, \mathrm{C}_{10} \mathrm{H}_{8} \mathrm{ClF}_{3} \mathrm{O}_{2}, \quad 252.62\right.$ $\mathrm{g} / \mathrm{mol}, 1.35 \mathrm{~g} / \mathrm{mL}, 148 \mu \mathrm{L}[2 \times 74 \mu \mathrm{L}$ ], $200 \mathrm{mg}$ [ $2 \times 100 \mathrm{mg}$ ], $792 \mu \mathrm{mol})$, pyridine $\left(\mathrm{C}_{5} \mathrm{H}_{5} \mathrm{~N}, 79.1 \mathrm{~g} / \mathrm{mol}, 0.98\right.$ $\mathrm{g} / \mathrm{mL}, 241 \mu \mathrm{L}[2 \times 120.5 \mu \mathrm{L}], 236 \mathrm{mg}[2 \times 118 \mathrm{mg}], 2.98 \mathrm{mmol}), 4$-(dimethylamino)pyridine (DMAP, 
$\mathrm{C}_{7} \mathrm{H}_{10} \mathrm{~N}_{2}, 122.17 \mathrm{~g} / \mathrm{mol}, 72 \mathrm{mg}$ [2×36 mg], $\left.589 \mu \mathrm{mol}\right)$ in $\mathrm{CH}_{2} \mathrm{Cl}_{2}(10 \mathrm{~mL}$ [2×5 mL]) to deliver (-)-S18 $\left(\mathrm{C}_{45} \mathrm{H}_{66} \mathrm{ClF}_{3} \mathrm{O}_{12}, 891.46 \mathrm{~g} / \mathrm{mol}, 164 \mathrm{mg}, 184 \mu \mathrm{mol}, 81 \%\right.$ considering that $16.3 \% \mathrm{~m} / \mathrm{m}$ of the total product from the aldol reaction were used, $\mathrm{dr} \geq 95: 5$ according to NMR evaluation) as a viscous colorless oil. $\mathrm{R}_{\mathrm{f}}$ 0.51 (cyclohexane-ethyl acetate, $2: 1) ;[\alpha]_{\mathrm{D}}{ }^{25}=-6.2\left(c=1, \mathrm{CHCl}_{3}\right) ;{ }^{1} \mathrm{H}$ and ${ }^{13} \mathrm{C}$ NMR spectra show trace amounts of chloroform: ${ }^{1} \mathrm{H}$ NMR $\left(\mathrm{CDCl}_{3}, 500 \mathrm{MHz}\right) \delta 0.77\left(\mathrm{~d}, J=7.3 \mathrm{~Hz}, 3 \mathrm{H}, 21^{\prime}-\mathrm{CH}_{3}\right), 0.95(\mathrm{~d}, J=6.7$ $\left.\mathrm{Hz}, 3 \mathrm{H}, 17^{\prime}-\mathrm{CH}_{3}\right), 1.00\left(\mathrm{~d}, J=6.9 \mathrm{~Hz}, 3 \mathrm{H}, 23^{\prime}-\mathrm{CH}_{3}\right), 1.36\left(\mathrm{~s}, 3 \mathrm{H}\right.$, acetonide- $\left.\mathrm{CH}_{3}\right), 1.37$ (s, 3H, acetonide$\left.\mathrm{CH}_{3}\right), 1.45\left(\mathrm{~s}, 3 \mathrm{H}\right.$, acetonide- $\left.\mathrm{CH}_{3}\right), 1.49\left(\mathrm{~s}, 3 \mathrm{H}\right.$, acetonide- $\left.\mathrm{CH}_{3}\right), 1.50-1.57\left(\mathrm{~m}, 4 \mathrm{H}, 19\right.$ '- $\left.\mathrm{CH}_{3}+24-\mathrm{CH}_{2}\right)$, 1.91 (ddd, $\left.J=14.4,9.3,2.8 \mathrm{~Hz}, 1 \mathrm{H}, 24-\mathrm{CH}_{2}\right), 2.02-2.13(\mathrm{~m}, 2 \mathrm{H}, 21-\mathrm{CH}+23-\mathrm{CH}), 2.16$ (apparent t, $J=$ 7.1, 2H, 16- $\mathrm{CH}_{2}$ ), 2.58 (apparent dsxt, $J=9.6,6.9 \mathrm{~Hz}, 1 \mathrm{H}, 17-\mathrm{CH}$ ), 2.78 (dd, $J=17.4,3.3 \mathrm{~Hz}, 1 \mathrm{H}, 12$ $\mathrm{CH}_{2}$ ), 3.02 (dd, $\left.J=17.4,8.0 \mathrm{~Hz}, 1 \mathrm{H}, 12-\mathrm{CH}_{2}\right), 3.31$ (s, 3H, MOM-CH 3$), 3.38$ (s, 3H, MOM-CH 3$), 3.50$ (s, $\left.3 \mathrm{H},-\mathrm{OCH}_{3}\right), 3.65(\mathrm{~d}, J=9.6 \mathrm{~Hz}, 1 \mathrm{H}, 20-\mathrm{CH}), 3.68(\mathrm{dd}, J=4.0,1.9 \mathrm{~Hz}, 1 \mathrm{H}, 22-\mathrm{CH}), 3.88(\mathrm{dd}, J=8.4,6.5$ $\left.\mathrm{Hz}, 1 \mathrm{H}, 27-\mathrm{CH}_{2}\right), 4.03-4.09\left(\mathrm{~m}, 2 \mathrm{H}, 25-\mathrm{CH}+27-\mathrm{CH}_{2}\right), 4.24$ (apparent td, $\left.J=6.5,5.3 \mathrm{~Hz}, 1 \mathrm{H}, 26-\mathrm{CH}\right)$, $4.43\left(\mathrm{~d}, J=6.3 \mathrm{~Hz}, 1 \mathrm{H}, \mathrm{MOM}-\mathrm{CH}_{2}\right), 4.46(\mathrm{dd}, J=7.1,4.5 \mathrm{~Hz}, 1 \mathrm{H}, 10-\mathrm{CH}), 4.48(\mathrm{~d}, J=6.1 \mathrm{~Hz}, 1 \mathrm{H}$, MOM-CH $), 4.57$ (d, $\left.J=6.8 \mathrm{~Hz}, 1 \mathrm{H}, \mathrm{MOM}_{-} \mathrm{CH}_{2}\right), 4.67-4.73\left(\mathrm{~m}, 2 \mathrm{H}, 9-\mathrm{CH}+\mathrm{MOM}-\mathrm{CH}_{2}\right), 5.14(\mathrm{~d}, J=9.4$ $\mathrm{Hz}, 1 \mathrm{H}, 18-\mathrm{CH}$ ), 5.23 (apparent dt, $J=10.5,1.1 \mathrm{~Hz}, 1 \mathrm{H}, 8^{\prime}-\mathrm{CH}_{2}$ ), 5.37 (apparent dt, $J=17.1,1.3 \mathrm{~Hz}, 1 \mathrm{H}$, 8'- $-\mathrm{CH}_{2}$ ), 5.62 (ddd, $\left.J=7.8,4.3,3.4 \mathrm{~Hz}, 1 \mathrm{H}, 11-\mathrm{CH}\right), 5.79$ (ddd, $\left.J=17.1,10.4,6.8 \mathrm{~Hz}, 1 \mathrm{H}, 8-\mathrm{CH}\right), 6.01$ $(\mathrm{d}, J=15.9,1 \mathrm{H}, 14-\mathrm{CH}), 6.70$ (apparent dt, $J=15.6,7.4 \mathrm{~Hz}, 1 \mathrm{H}, 15-\mathrm{CH}), 7.33-7.40(\mathrm{~m}, 3 \mathrm{H}, 3 \times \mathrm{Ph}-\mathrm{CH})$, 7.48-7.53 (m, 2H, 2×Ph-CH); ${ }^{13} \mathrm{C} \mathrm{NMR}\left(\mathrm{CDCl}_{3}, 126 \mathrm{MHz}\right) \delta 11.3\left(\mathrm{CH}_{3}\right), 12.6\left(\mathrm{CH}_{3}\right), 16.9\left(\mathrm{CH}_{3}\right), 20.8$ $\left(\mathrm{CH}_{3}\right), 25.0\left(\mathrm{CH}_{3}\right), 25.4\left(\mathrm{CH}_{3}\right), 26.3\left(\mathrm{CH}_{3}\right), 27.1\left(\mathrm{CH}_{3}\right), 30.6(\mathrm{CH}), 32.0(\mathrm{CH}), 38.9(\mathrm{CH}), 39.8\left(\mathrm{CH}_{2}\right)$, $39.9\left(\mathrm{CH}_{2}\right), 40.3\left(\mathrm{CH}_{2}\right), 55.5\left(\mathrm{CH}_{3}\right), 55.8\left(\mathrm{CH}_{3}\right), 56.2\left(\mathrm{CH}_{3}\right), 61.5(\mathrm{CH}), 66.6\left(\mathrm{CH}_{2}\right), 71.8(\mathrm{CH}), 77.8$ $(\mathrm{CH}), 78.0(\mathrm{CH}), 78.8(\mathrm{CH}), 79.8(\mathrm{CH}), 84.3(\mathrm{q}, J=27.4 \mathrm{~Hz}, \mathrm{C}), 85.5(\mathrm{CH}), 94.7\left(\mathrm{CH}_{2}\right), 96.8\left(\mathrm{CH}_{2}\right)$, $109.1(\mathrm{C}), 110.0(\mathrm{C}), 119.4\left(\mathrm{CH}_{2}\right), 123.3(\mathrm{q}, J=287.2 \mathrm{~Hz}, \mathrm{C}), 127.7(\mathrm{CH}), 128.4(\mathrm{CH}), 129.6(\mathrm{CH}), 131.4$ $(\mathrm{CH}), 132.0(\mathrm{C}), 132.4(\mathrm{CH}), 133.0(\mathrm{C}), 135.5(\mathrm{CH}), 146.4(\mathrm{CH}), 165.6(\mathrm{C}), 195.5(\mathrm{C}) ;{ }^{19} \mathrm{~F} \mathrm{NMR}\left(\mathrm{CDCl}_{3}\right.$, $471 \mathrm{MHz}) \delta$-71.6; IR $\vee 2935(\mathrm{w}), 1750(\mathrm{~m}), 1675(\mathrm{w}), 1455(\mathrm{w}), 1380(\mathrm{~m}), 1255$ (m), $1210(\mathrm{~m}), 1165$ (m), $1025(\mathrm{~s}), 920(\mathrm{~m}), 855(\mathrm{~m}), 765(\mathrm{w}), 720(\mathrm{~m}), 510(\mathrm{w}) \mathrm{cm}^{-1}$; HRMS (ESI): m/z [M + Na] $]^{+}$Calcd. for $\mathrm{C}_{45} \mathrm{H}_{66} \mathrm{ClF}_{3} \mathrm{NaO}_{12}$ : 913.40871; Found: 913.40861.

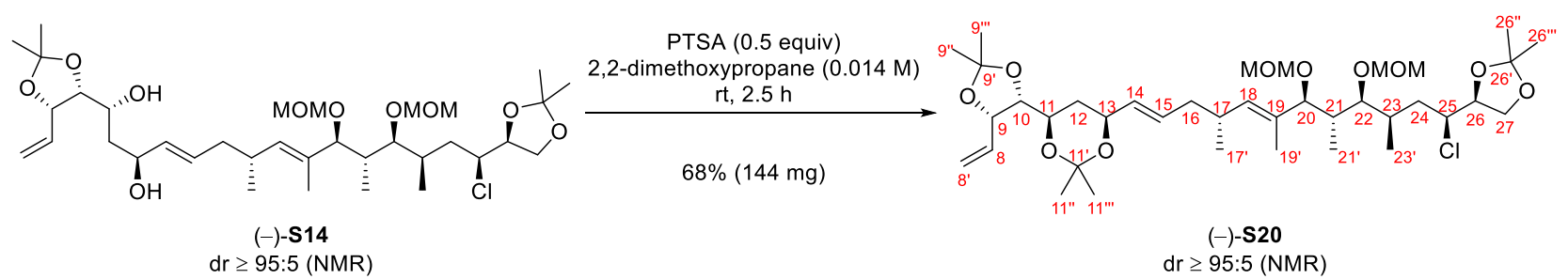

Tris-acetal (-)-S20. To a stirred solution of syn-11,13-diol (-)-S14 $\left(\mathrm{C}_{35} \mathrm{H}_{61} \mathrm{ClO}_{10}, 677.31 \mathrm{~g} / \mathrm{mol}, 200 \mathrm{mg}\right.$, $295 \mu \mathrm{mol}, 1$ equiv) in 2,2-dimethoxypropane $(20.7 \mathrm{~mL}, 0.014 \mathrm{M})$ at ambient temperature was added $p$ toluenesulfonic acid monohydrate (PTSA, $\mathrm{C}_{7} \mathrm{H}_{10} \mathrm{O}_{4} \mathrm{~S}, 190.21 \mathrm{~g} / \mathrm{mol}, 28 \mathrm{mg}, 147 \mu \mathrm{mol}, 0.5$ equiv) to afford a clear colorless solution. After being stirred for $2.5 \mathrm{~h}$ at ambient temperature, the clear colorless solution was diluted by the addition of aqueous phosphate buffer $(\mathrm{pH} \mathrm{7)}$ at ambient temperature. The resulting colorless biphasic mixture was transferred into a separatory funnel using $\mathrm{CH}_{2} \mathrm{Cl}_{2}$ for rinsing. The phases were separated, and the aqueous layer was extracted with $\mathrm{CH}_{2} \mathrm{Cl}_{2}(4 \times)$. The combined organic layers were dried $\left(\mathrm{MgSO}_{4}\right)$. Removal of all volatiles under reduced pressure and subsequent purification of the colorless oil by flash chromatography (cyclohexane-ethyl acetate, 20:1 to 10:1) delivered (-)-S20 $\left(\mathrm{C}_{38} \mathrm{H}_{65} \mathrm{ClO}_{10}, 717.38 \mathrm{~g} / \mathrm{mol}, 144 \mathrm{mg}, 201 \mu \mathrm{mol}, 68 \%\right.$, dr $\geq 95: 5$ according to NMR evaluation $)$ as a clear colorless oil. The assignment of the absolute configuration of 11-CH and 13-CH rests on the interpretation of the ${ }^{1} \mathrm{H}$ NMR data of the Mosher esters $(S)-(-)-S 19$ and $(R)-(-)-S 18$ as well as of the ${ }^{13} \mathrm{C}$ NMR data of the tris-acetal $(-)$-S20. The ${ }^{1} \mathrm{H}$ NMR chemical shifts for $(S)-(-)$-S19 and $(R)-(-)$-S18 suggest a $(11 R)-$ configuration (Figure SI-1-4). The ${ }^{13} \mathrm{C}$ NMR chemical shifts of $(-)-\mathbf{S 2 0}$ for the acetonide at $11-\mathrm{CH}$ and 13-CH suggest a 11,13-syn-configuration (Figure SI-1-5) and, therefore, supports the assumption of a $(13 S)$-configuration. $\mathrm{R}_{\mathrm{f}} 0.69$ (cyclohexane-ethyl acetate, $\left.1: 1\right) ;[\alpha]_{\mathrm{D}}{ }^{20}=-51.0\left(c=1, \mathrm{CHCl}_{3}\right) ;{ }^{1} \mathrm{H}$ NMR $\left(\mathrm{CDCl}_{3}, 400 \mathrm{MHz}\right) \delta 0.78\left(\mathrm{~d}, J=7.3 \mathrm{~Hz}, 3 \mathrm{H}, 21^{\prime}-\mathrm{CH}_{3}\right), 0.92\left(\mathrm{~d}, J=6.7 \mathrm{~Hz}, 3 \mathrm{H}, 17-\mathrm{CH}_{3}\right), 1.00(\mathrm{~d}, J=6.9$ $\left.\mathrm{Hz}, 3 \mathrm{H}, 23 '-\mathrm{CH}_{3}\right), 1.33-1.36\left(\mathrm{~m}, 6 \mathrm{H}, 11^{\prime \prime}-\mathrm{CH}_{3}\right.$ or $11^{\prime \prime}-\mathrm{CH}_{3}+9 "-\mathrm{CH}_{3}$ or 9"'- $\left.\mathrm{CH}_{3}\right), 1.36-1.42(\mathrm{~m}, 7 \mathrm{H}, 26$ "- 


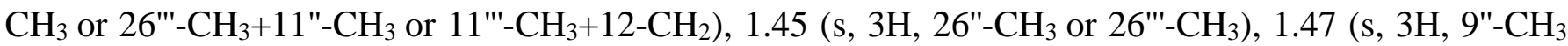
or 9'"- $\left.\mathrm{CH}_{3}\right), 1.49-1.58\left(\mathrm{~m}, 4 \mathrm{H}, 19 '-\mathrm{CH}_{3}+24-\mathrm{CH}_{2}\right), 1.72$ (apparent dt, $\left.J=13.0,2.4 \mathrm{~Hz}, 1 \mathrm{H}, 12-\mathrm{CH}_{2}\right), 1.92$ (ddd, $J=14.4,9.2,2.8 \mathrm{~Hz}, 1 \mathrm{H}, 24-\mathrm{CH}_{2}$ ), 2.01 (apparent t, $J=6.9 \mathrm{~Hz}, 2 \mathrm{H}, 16-\mathrm{CH}_{2}$ ), 2.04-2.15 (m, 2H, 21$\mathrm{CH}+23-\mathrm{CH}), 2.47$ (apparent dsxt, $J=9.3,6.9 \mathrm{~Hz}, 1 \mathrm{H}, 17-\mathrm{CH}), 3.35$ (s, 3H, MOM-CH 3$), 3.37(\mathrm{~s}, 3 \mathrm{H}$, MOM-CH $), 3.64-3.70(\mathrm{~m}, 2 \mathrm{H}, 20-\mathrm{CH}+22-\mathrm{CH}), 3.83-3.91\left(\mathrm{~m}, 2 \mathrm{H}, 11-\mathrm{CH}+27-\mathrm{CH}_{2}\right), 3.94(\mathrm{dd}, J=8.5$, $6.3 \mathrm{~Hz}, 1 \mathrm{H}, 10-\mathrm{CH}), 4.03-4.11\left(\mathrm{~m}, 2 \mathrm{H}, 25-\mathrm{CH}+27-\mathrm{CH}_{2}\right), 4.21-4.32(\mathrm{~m}, 2 \mathrm{H}, 13-\mathrm{CH}+26-\mathrm{CH}), 4.47(\mathrm{~d}, J=$

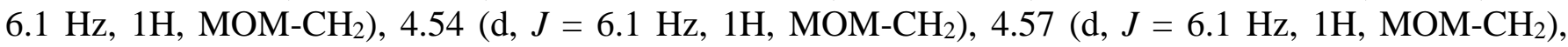
4.63-4.71 (m, 2H, MOM-CH $2+9-\mathrm{CH}), 5.14(\mathrm{~d}, J=8.8 \mathrm{~Hz}, 1 \mathrm{H}, 18-\mathrm{CH}), 5.20$ (apparent dt, $J=10.5,1.4$ $\mathrm{Hz}, 1 \mathrm{H}, 8$ '- $\mathrm{CH}_{2}$ ), 5.36 (apparent dt, $\left.J=17.2,1.6 \mathrm{~Hz}, 1 \mathrm{H}, 8^{\prime}-\mathrm{CH}_{2}\right), 5.44$ (dd, $J=15.4,6.4 \mathrm{~Hz}, 1 \mathrm{H}, 14-\mathrm{CH}$ ), 5.64 (apparent dt, $J=14.9,7.5 \mathrm{~Hz}, 1 \mathrm{H}, 15-\mathrm{CH}), 5.89$ (ddd, $J=17.0,10.7,6.1 \mathrm{~Hz}, 1 \mathrm{H}, 8-\mathrm{CH}) ;{ }^{13} \mathrm{C}$ NMR $\left(\mathrm{CDCl}_{3}, 101 \mathrm{MHz}\right) \delta 11.3\left(19^{\prime}-\mathrm{CH}_{3}\right), 12.7\left(21^{\prime}-\mathrm{CH}_{3}\right), 16.8\left(23^{\prime}-\mathrm{CH}_{3}\right), 19.7\left(11^{\prime \prime}-\mathrm{CH}_{3}\right.$ or 11'"-- $\left.\mathrm{CH}_{3}\right), 20.6$

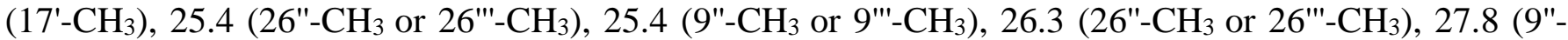
$\mathrm{CH}_{3}$ or 9"'-- $\left.\mathrm{CH}_{3}\right), 30.2\left(11 "-\mathrm{CH}_{3}\right.$ or $\left.11^{\prime \prime}-\mathrm{CH}_{3}\right), 30.7(23-\mathrm{CH}), 32.5(17-\mathrm{CH}), 34.7\left(12-\mathrm{CH}_{2}\right), 39.1(21-\mathrm{CH})$, $40.0\left(24-\mathrm{CH}_{2}\right), 40.1\left(16-\mathrm{CH}_{2}\right), 55.8\left(\mathrm{MOM}-\mathrm{CH}_{3}\right), 56.3\left(\mathrm{MOM}-\mathrm{CH}_{3}\right), 61.5(25-\mathrm{CH}), 66.6\left(27-\mathrm{CH}_{2}\right), 67.6$ (11-CH), 70.0 (13-CH), $78.7(9-\mathrm{CH}), 78.8(26-\mathrm{CH}), 80.0(10-\mathrm{CH}), 80.0(22-\mathrm{CH}), 85.3(20-\mathrm{CH}), 94.7$

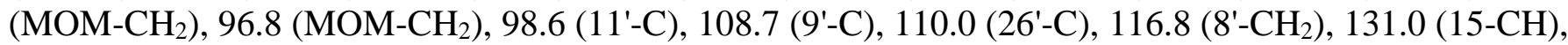
131.8 (19-C), 131.9 (14-CH), 134.2 (8-CH), 136.8 (18-CH); IR v 2930 (w), 1455 (w), 1370 (m), 1250 $(\mathrm{m}), 1205(\mathrm{~m}), 1155(\mathrm{~m}), 1030(\mathrm{~s}), 965(\mathrm{~m}), 920(\mathrm{~m}), 855(\mathrm{~m}), 515(\mathrm{w}) \mathrm{cm}^{-1}$; Anal. Calcd. for $\mathrm{C}_{38} \mathrm{H}_{65} \mathrm{ClO}_{10}$ : C, 63.6; H, 9.1; Found: C, 63.7; H, 9.2; HRMS (ESI): $\mathrm{m} / \mathrm{z}\left[\mathrm{M}+\mathrm{Na}^{+} \mathrm{Calcd}\right.$. for $\mathrm{C}_{38} \mathrm{H}_{65} \mathrm{ClNaO}_{10}$ : 739.41585; Found: 739.41570 .

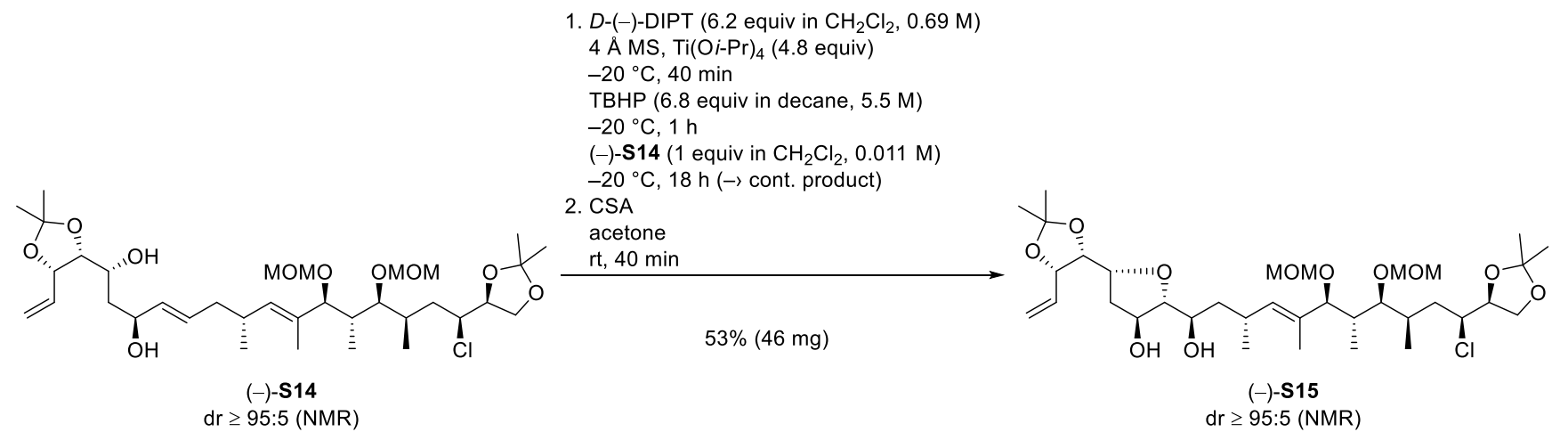

Tetrahydrofurane (-)-S15. To a stirred colorless solution of freshly distilled $\left(0.05 \mathrm{mbar}, 150{ }^{\circ} \mathrm{C}\right) \mathrm{D}$-(-)diisopropyl tartrate $\left(D-(-)\right.$-DIPT, $\mathrm{C}_{10} \mathrm{H}_{18} \mathrm{O}_{6}, 234.25 \mathrm{~g} / \mathrm{mol}, 1.119 \mathrm{~g} / \mathrm{mL}, 163 \mu \mathrm{L}, 182 \mathrm{mg}, 777 \mu \mathrm{mol}, 6.2$ equiv) in $\mathrm{CH}_{2} \mathrm{Cl}_{2}(11.25 \mathrm{~mL}, 0.69 \mathrm{M})$ at ambient temperature was added powdered $4 \AA$ molecular sieves (340 mg, $4 \mathrm{mg} / \mathrm{mg}(-)-$ S14) to afford a slightly orange suspension. The suspension was cooled to $-20{ }^{\circ} \mathrm{C}$ and freshly distilled $\left(1 \mathrm{mbar}, 125^{\circ} \mathrm{C}\right)$ titanium(IV) isopropoxide $\left(\mathrm{Ti}(\mathrm{O} i \text { - } \mathrm{Pr})_{4}, \mathrm{C}_{12} \mathrm{H}_{18} \mathrm{O}_{4} \mathrm{Ti}, 284.22 \mathrm{~g} / \mathrm{mol}\right.$, $0.96 \mathrm{~g} / \mathrm{mL}, 178 \mu \mathrm{L}, 171 \mathrm{mg}, 602 \mu \mathrm{mol}, 4.8$ equiv) was added to afford a slightly orange suspension. After being stirred for $40 \mathrm{~min}$ at $-20{ }^{\circ} \mathrm{C}$, tert-butyl hydroperoxide (TBHP, $\mathrm{C}_{4} \mathrm{H}_{10} \mathrm{O}_{2}, 5.5 \mathrm{M}$ in decane, $155 \mu \mathrm{L}$, $853 \mu \mathrm{mol}, 6.8$ equiv) was added dropwise at $-20{ }^{\circ} \mathrm{C}$ and stirring was continued at $-20{ }^{\circ} \mathrm{C}$ for $1 \mathrm{~h}$. A solution of the syn-11,13-diol (-)-S14 $\left(\mathrm{C}_{35} \mathrm{H}_{61} \mathrm{ClO}_{10}, 677.31 \mathrm{~g} / \mathrm{mol}, 85 \mathrm{mg}, 125 \mu \mathrm{mol}, 1\right.$ equiv) in $\mathrm{CH}_{2} \mathrm{Cl}_{2}$ (11.25 mL, $0.011 \mathrm{M}$; overall: $0.006 \mathrm{M}$ in $\mathrm{CH}_{2} \mathrm{Cl}_{2}$ ) was added dropwise at $-20{ }^{\circ} \mathrm{C}$ to afford an orange suspension. After being stirred for $18 \mathrm{~h}$ at $-20{ }^{\circ} \mathrm{C}$, the orange suspension was diluted at $-20{ }^{\circ} \mathrm{C}$ by the addition of aqueous $\mathrm{NaOH}$ solution $(3 \mathrm{~N})$. The resulting orange biphasic mixture was allowed to warm to ambient temperature. After being stirred for $15 \mathrm{~min}$ at ambient temperature, saturated aqueous $\mathrm{Na}_{2} \mathrm{~S}_{2} \mathrm{O}_{3}$ solution was added and stirring was continued for $15 \mathrm{~min}$. Solid potassium sodium tartrate was added and stirring was continued for $15 \mathrm{~min}$ at ambient temperature. The resulting orange biphasic mixture was diluted further by the addition of methanol $(1.2 \mathrm{~mL})$ at ambient temperature. The resulting orange biphasic mixture was transferred into a separatory funnel using $\mathrm{CH}_{2} \mathrm{Cl}_{2}$ for rinsing. The phases were separated, and the aqueous layer was extracted with $\mathrm{CH}_{2} \mathrm{Cl}_{2}(5 \times)$. The combined organic layers were dried $\left(\mathrm{MgSO}_{4}\right)$. Removal of all volatiles under reduced pressure and attempted purification of the cloudy colorless oil by flash chromatography (cyclohexane-ethyl acetate, 10:1 to 1:1) delivered a clear colorless 
oil (105 mg). NMR analysis revealed significant but inseparable impurities of $D$-(-)-DIPT and $\mathrm{Ti}(\mathrm{O} i \text {-Pr) })_{4}$, and the clear colorless oil was used without further purification.

To a stirred solution of the clear colorless oil $(105 \mathrm{mg})$ in acetone $(12.5 \mathrm{~mL})$ at ambient temperature was added (+)-camphor-10-sulfonic acid $\left(\mathrm{CSA}, \mathrm{C}_{10} \mathrm{H}_{16} \mathrm{O}_{4} \mathrm{~S}, 232.3 \mathrm{~g} / \mathrm{mol}, 35 \mathrm{mg}, 151 \mu \mathrm{mol}\right)$ to afford a clear colorless solution. After being stirred for $40 \mathrm{~min}$ at ambient temperature, the clear colorless solution was diluted by the addition of aqueous phosphate buffer ( $\mathrm{pH} 7$ ) at ambient temperature. The resulting colorless biphasic mixture was transferred into a separatory funnel using $\mathrm{CH}_{2} \mathrm{Cl}_{2}$ for rinsing. The phases were separated, and the aqueous layer was extracted with $\mathrm{CH}_{2} \mathrm{Cl}_{2}(5 \times)$. The combined organic layers were dried $\left(\mathrm{MgSO}_{4}\right)$. Removal of all volatiles under reduced pressure and subsequent purification of the colorless oil by flash chromatography (cyclohexane-ethyl acetate, 10:1 to 1:2) delivered (-)-S15 $\left(\mathrm{C}_{35} \mathrm{H}_{61} \mathrm{ClO}_{11}, 693.31\right.$ $\mathrm{g} / \mathrm{mol}, 46 \mathrm{mg}, 66 \mu \mathrm{mol}, 53 \%, \mathrm{dr} \geq 95: 5$ according to NMR evaluation; note: the diastereomeric epoxide could not be isolated) as a clear colorless oil. $\mathrm{R}_{\mathrm{f}} 0.14$ (cyclohexane-ethyl acetate, $\left.1: 1\right) ;[\alpha]_{\mathrm{D}}{ }^{20}=-20.9(c=$ $\left.1, \mathrm{CHCl}_{3}\right) ;{ }^{1} \mathrm{H} \mathrm{NMR}\left(\mathrm{CDCl}_{3}, 500 \mathrm{MHz}\right) \delta 0.78\left(\mathrm{~d}, J=7.2 \mathrm{~Hz}, 3 \mathrm{H}, 21^{\prime}-\mathrm{CH}_{3}\right), 0.94\left(\mathrm{~d}, J=6.6 \mathrm{~Hz}, 3 \mathrm{H}, 17^{\prime}-\right.$ $\left.\mathrm{CH}_{3}\right), 0.99\left(\mathrm{~d}, J=6.9 \mathrm{~Hz}, 3 \mathrm{H}, 23{ }^{\prime}-\mathrm{CH}_{3}\right), 1.36\left(\mathrm{~s}, 3 \mathrm{H}\right.$, acetonide- $\left.\mathrm{CH}_{3}\right), 1.37$ (s, 3H, acetonide- $\left.\mathrm{CH}_{3}\right), 1.38-$ $1.44\left(\mathrm{~m}, 1 \mathrm{H}, 16-\mathrm{CH}_{2}\right), 1.44-1.53\left(\mathrm{~m}, 7 \mathrm{H}\right.$, acetonide- $\mathrm{CH}_{3}$ acetonide- $\left.\mathrm{CH}_{3}+24-\mathrm{CH}_{2}\right), 1.59\left(\mathrm{~s}, 3 \mathrm{H}, 19\right.$ '- $\left.\mathrm{CH}_{3}\right)$, $1.66\left(\mathrm{ddd}, J=14.0,5.3,3.1 \mathrm{~Hz}, 1 \mathrm{H}, 16-\mathrm{CH}_{2}\right), 1.84-1.94\left(\mathrm{~m}, 2 \mathrm{H}, 24-\mathrm{CH}_{2}+12-\mathrm{CH}_{2}\right), 2.04-2.11(\mathrm{~m}, 2 \mathrm{H}, 21-$ $\mathrm{CH}+23-\mathrm{CH}), 2.15$ (apparent dt, $\left.J=13.4,7.4 \mathrm{~Hz}, 1 \mathrm{H}, 12-\mathrm{CH}_{2}\right), 2.31$ (br. s, 1H, -OH), 2.56-2.66 (m, 1H, 17-CH), 3.36 (s, 3H, MOM-CH 3 ), 3.37 (s, 3H, MOM-CH CH $_{3} 3.40$ (br s, $\left.1 \mathrm{H},-\mathrm{OH}\right), 3.49$ (dd, $J=5.6,3.8$ $\mathrm{Hz}, 1 \mathrm{H}, 14-\mathrm{CH}), 3.56-3.62(\mathrm{~m}, 2 \mathrm{H}, 15-\mathrm{CH}+20-\mathrm{CH}), 3.72(\mathrm{~d}, J=3.1 \mathrm{~Hz}, 1 \mathrm{H}, 22-\mathrm{CH}), 3.87(\mathrm{dd}, J=8.4$, $\left.6.5 \mathrm{~Hz}, 1 \mathrm{H}, 27-\mathrm{CH}_{2}\right), 4.01(\mathrm{ddd}, J=11.1,5.3,2.3 \mathrm{~Hz}, 1 \mathrm{H}, 25-\mathrm{CH}), 4.06(\mathrm{dd}, J=8.4,6.8 \mathrm{~Hz}, 1 \mathrm{H}, 27-$ $\mathrm{CH}_{2}$ ), 4.10-4.16 (m, 1H, 11-CH), 4.20-4.25 (m, 2H, 10-CH+26-CH), 4.32 (apparent dt, $J=6.8,3.4 \mathrm{~Hz}$,

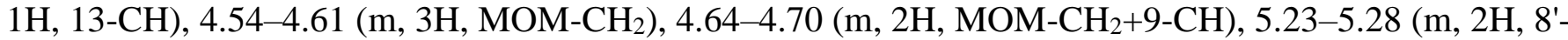
$\left.\mathrm{CH}_{2}+18-\mathrm{CH}\right), 5.37$ (d, $\left.J=17.1 \mathrm{~Hz}, 1 \mathrm{H}, 8{ }^{\prime}-\mathrm{CH}_{2}\right), 5.85$ (ddd, $\left.J=17.1,10.4,6.8 \mathrm{~Hz}, 1 \mathrm{H}, 8-\mathrm{CH}\right) ;{ }^{13} \mathrm{C}$ NMR $\left(\mathrm{CDCl}_{3}, 126 \mathrm{MHz}\right) \delta 11.4\left(\mathrm{CH}_{3}\right), 12.4\left(\mathrm{CH}_{3}\right), 16.9\left(\mathrm{CH}_{3}\right), 21.2\left(\mathrm{CH}_{3}\right), 25.2\left(\mathrm{CH}_{3}\right), 25.3\left(\mathrm{CH}_{3}\right), 26.4\left(\mathrm{CH}_{3}\right)$, $27.2\left(\mathrm{CH}_{3}\right), 30.1(\mathrm{CH}), 30.7(\mathrm{CH}), 37.0\left(\mathrm{CH}_{2}\right), 38.6(\mathrm{CH}), 39.8\left(\mathrm{CH}_{2}\right), 41.5\left(\mathrm{CH}_{2}\right), 55.8\left(\mathrm{CH}_{3}\right), 56.4$ $\left(\mathrm{CH}_{3}\right), 61.4(\mathrm{CH}), 66.6\left(\mathrm{CH}_{2}\right), 72.5(\mathrm{CH}), 73.7(\mathrm{CH}), 77.1(\mathrm{CH}), 78.3(\mathrm{CH}), 78.8(\mathrm{CH}), 78.8(\mathrm{CH}), 79.9$ $(\mathrm{CH}), 88.0(\mathrm{CH}), 88.9(\mathrm{CH}), 96.3\left(\mathrm{CH}_{2}\right), 96.5\left(\mathrm{CH}_{2}\right), 108.8(\mathrm{C}), 110.0(\mathrm{C}), 118.3\left(\mathrm{CH}_{2}\right), 132.2(\mathrm{C}), 133.7$ $(\mathrm{CH}), 136.4(\mathrm{CH}) ; \mathrm{IR} \vee 3460(\mathrm{w}), 2930(\mathrm{w}), 1740(\mathrm{w}), 1455(\mathrm{w}), 1370(\mathrm{~m}), 1245(\mathrm{~m}), 1215(\mathrm{~m}), 1155$ (m), $1090(\mathrm{~m}), 1030$ (s), $920(\mathrm{~m}), 875$ (m), 515 (w) cm ${ }^{-1}$; HRMS (ESI): m/z [M + Na] ${ }^{+}$Calcd. for $\mathrm{C}_{35} \mathrm{H}_{61} \mathrm{ClNaO}_{11}$ : 715.37946; Found: 715.37948, $\mathrm{m} / \mathrm{z}[\mathrm{M}+\mathrm{K}]^{+}$Calcd. for $\mathrm{C}_{35} \mathrm{H}_{61} \mathrm{ClKO}_{11}$ : 731.35340; Found: $731.35336, \mathrm{~m} / \mathrm{z}\left[\mathrm{M}+\mathrm{NH}_{4}\right]^{+}$Calcd. for $\mathrm{C}_{35} \mathrm{H}_{65} \mathrm{ClNO}_{11}: 710.42407$; Found: 710.42435 .
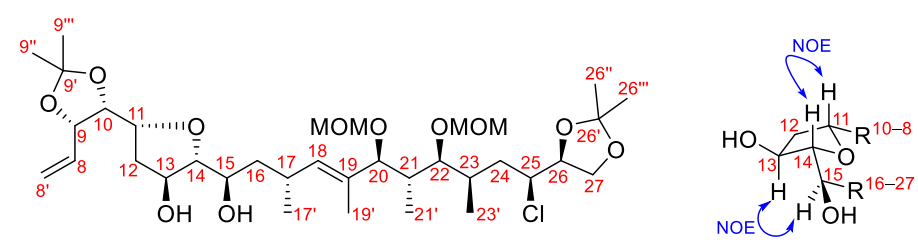

$(-)-S 15$

Table SI-1-1. Assignment of the absolute configuration for (-)-S15.

\begin{tabular}{|c|c|}
\hline carbon atom & foundation for assignment \\
\hline 9-CH & ex-chiral-pool synthesis \\
\hline $10-\mathrm{CH}$ & ex-chiral-pool synthesis \\
\hline $11-\mathrm{CH}$ & Mosher's configurational correlation model (Figure SI-1-3 and Figure SI-1-4) \\
\hline $13-\mathrm{CH}$ & ${ }^{13} \mathrm{C}$ NMR acetonide analysis of Rychnovsky for tris-acetal (-)-S20 (Figure SI-1-5) \\
\hline 14-CH & $\begin{array}{l}\text { asymmetric synthesis: applying the accepted stereochemical model for the Sharpless } \\
\text { asymmetric epoxidation (SAE) and assuming a diastereospecific 5-exo-tet- } \\
\text { tetrahydrofurane ring formation by concerted } \mathrm{S}_{\mathrm{N}} \text { i ring opening of the epoxide; NMR } \\
\text { spectroscopy: NOE correlation experimentally observed between } 15-\mathrm{CH} \text { and } 13-\mathrm{CH}, 13- \\
\mathrm{CH} \text { and } 12-\mathrm{CH}_{2} \mathrm{Si}, 14-\mathrm{CH} \text { and } 11-\mathrm{CH}, 11-\mathrm{CH} \text { and } 12-\mathrm{CH}_{2}{ }^{R e}\end{array}$ \\
\hline $15-\mathrm{CH}$ & asymmetric synthesis: applying the accepted stereochemical model for the Sharpless \\
\hline
\end{tabular}


asymmetric epoxidation (SAE) and assuming a diastereospecific 5-exo-tettetrahydrofurane ring formation by concerted $S_{N i}$ ring opening of the epoxide; NMR spectroscopy: NOE experiment

17- $\mathrm{CH}$ asymmetric synthesis: applying accepted stereochemical model for asymmetric induction by chiral auxiliary; in accordance to the literature; no independent verification by spectroscopy or crystallography

20-CH Mosher's configurational correlation model (Figure SI-1-1 and Figure SI-1-2)

21-CH NOE experiment of methylene acetal (-)-12

22- $\mathrm{CH} \quad$ NOE experiment of methylene acetal (-)-12

23-CH asymmetric synthesis: applying accepted stereochemical model for asymmetric induction by chiral auxiliary; in accordance to the literature; no independent verification by spectroscopy or crystallography

25- $\mathrm{CH}$ ex-chiral-pool synthesis and diastereospecific $\mathrm{S}_{\mathrm{N}} 2$; in accordance to the literature; no independent verification by spectroscopy or crystallography

$26-\mathrm{CH}$ ex-chiral-pool synthesis

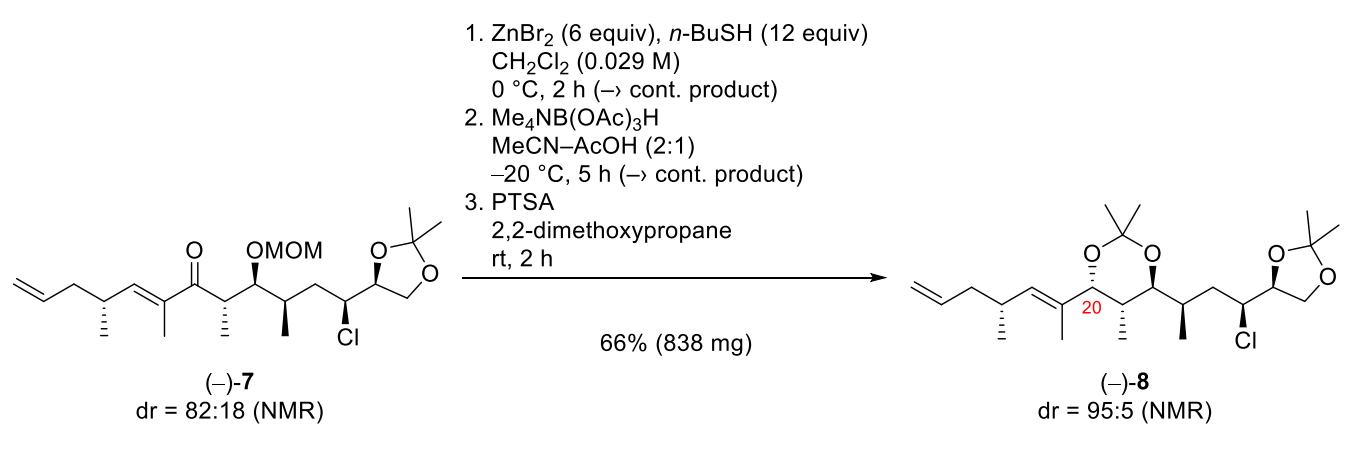

Bis-acetal (-)-8. To a stirred solution of a diastereomeric mixture $(\mathrm{dr}=82: 18)$ of the enone $(-)-7$ $\left(\mathrm{C}_{23} \mathrm{H}_{39} \mathrm{ClO}_{5}, 431.01 \mathrm{~g} / \mathrm{mol}, 1.27 \mathrm{~g}, 2.95 \mathrm{mmol}, 1\right.$ equiv) in $\mathrm{CH}_{2} \mathrm{Cl}_{2}(103 \mathrm{~mL}, 0.029 \mathrm{M})$ at $0{ }^{\circ} \mathrm{C}$ was added 1-butanethiol ( $n$-BuSH, $\mathrm{C}_{4} \mathrm{H}_{10} \mathrm{~S}, 90.18 \mathrm{~g} / \mathrm{mol}, 0.842 \mathrm{~g} / \mathrm{mL}, 1.9 \mathrm{~mL}, 1.6 \mathrm{~g}, 17.74 \mathrm{mmol}, 6$ equiv) and dried $\left(0.05\right.$ mbar, $\left.175{ }^{\circ} \mathrm{C}, 2 \mathrm{~h}\right)$ zinc(II) bromide $\left(\mathrm{ZnBr}_{2}, 225.2 \mathrm{~g} / \mathrm{mol}, 1.99 \mathrm{~g}, 8.84 \mathrm{mmol}, 3\right.$ equiv) to afford a grey suspension. After being stirred for $45 \mathrm{~min}$ at $0{ }^{\circ} \mathrm{C}$, additional $n$-BuSH $\left(\mathrm{C}_{4} \mathrm{H}_{10} \mathrm{~S}, 90.18 \mathrm{~g} / \mathrm{mol}, 0.842\right.$ $\mathrm{g} / \mathrm{mL}, 950 \mu \mathrm{L}, 800 \mathrm{mg}, 8.87 \mathrm{mmol}, 3$ equiv) and additional dried $\mathrm{ZnBr}_{2}(225.2 \mathrm{~g} / \mathrm{mol}, 1 \mathrm{~g}, 4.44 \mathrm{mmol}, 1.5$ equiv) were added. The resulting yellow grey suspension was stirred for $45 \mathrm{~min}$ at $0{ }^{\circ} \mathrm{C}$. Additional $n$ BuSH $\left(\mathrm{C}_{4} \mathrm{H}_{10} \mathrm{~S}, 90.18 \mathrm{~g} / \mathrm{mol}, 0.842 \mathrm{~g} / \mathrm{mL}, 950 \mu \mathrm{L}, 800 \mathrm{mg}, 8.87 \mathrm{mmol}, 3\right.$ equiv) and additional dried $\mathrm{ZnBr}_{2}(225.2 \mathrm{~g} / \mathrm{mol}, 1 \mathrm{~g}, 4.44 \mathrm{mmol}, 1.5$ equiv) were added to afford a yellow grey suspension. After being stirred for $30 \mathrm{~min}$ at $0{ }^{\circ} \mathrm{C}$, the yellow grey suspension was diluted by the addition of saturated aqueous $\mathrm{NaHCO}_{3}$ solution and saturated aqueous potassium sodium tartrate solution $(v / v=2: 1)$ at $0{ }^{\circ} \mathrm{C}$. The resulting yellow biphasic mixture was transferred into a separatory funnel using $\mathrm{CH}_{2} \mathrm{Cl}_{2}$ for rinsing. The phases were separated, and the aqueous layer was extracted with ethyl acetate $(5 x)$. The combined organic layers were dried $\left(\mathrm{MgSO}_{4}\right)$. Removal of all volatiles under reduced pressure and attempted purification of the cloudy yellow oil by flash chromatography (cyclohexane-ethyl acetate, 2:1 to 1:2) delivered a colorless oil (1.2 g). NMR analysis revealed significant but inseparable impurities, and the colorless oil was used without further purification.

To a stirred solution of the colorless oil $(1.2 \mathrm{~g})$ in acetonitrile $(207 \mathrm{~mL})$ and acetic acid $(103 \mathrm{~mL})$ at -20 ${ }^{\circ} \mathrm{C}$ was added tetramethylammonium triacetoxyborohydride $\left(\mathrm{Me}_{4} \mathrm{NB}(\mathrm{OAc})_{3} \mathrm{H}, 263.1 \mathrm{~g} / \mathrm{mol}, 4.31 \mathrm{~g}, 90 \%\right.$ purity, $3.88 \mathrm{~g}, 14.75 \mathrm{mmol}$ ) to afford a colorless suspension. After being stirred for $2.5 \mathrm{~h}$ at $-20{ }^{\circ} \mathrm{C}$, additional $\mathrm{Me}_{4} \mathrm{NB}(\mathrm{OAc}){ }_{3} \mathrm{H}(263.1 \mathrm{~g} / \mathrm{mol}, 862 \mathrm{mg}, 90 \%$ purity, $776 \mathrm{mg}, 2.95 \mathrm{mmol})$ was added at $-20{ }^{\circ} \mathrm{C}$ and the colorless reaction mixture was stirred at $-20{ }^{\circ} \mathrm{C}$ for $2.5 \mathrm{~h}$. The colorless reaction mixture was diluted by the very slow addition of saturated aqueous $\mathrm{K}_{2} \mathrm{CO}_{3}$ solution and water $(v / v=10: 1)$ at $0{ }^{\circ} \mathrm{C}$ till no more gas formation was observed. The resulting colorless biphasic mixture was transferred into a separatory funnel using ethyl acetate for rinsing. The phases were separated, and the aqueous layer was extracted with ethyl acetate (6x). The combined organic layers were dried $\left(\mathrm{MgSO}_{4}\right)$. Removal of all volatiles under reduced pressure and attempted purification of the colorless oil by flash chromatography 
$\left(\mathrm{CH}_{2} \mathrm{Cl}_{2}\right.$-methanol, 250:1 to 10:1) delivered a colorless oil (1.12 g). NMR analysis revealed significant but inseparable impurities, and the colorless viscous oil was used without further purification.

To a stirred solution of the colorless oil $(1.12 \mathrm{~g})$ in 2,2-dimethoxypropane $(88.5 \mathrm{~mL})$ at ambient temperature was added $p$-toluenesulfonic acid monohydrate (PTSA, $\mathrm{C}_{7} \mathrm{H}_{10} \mathrm{O}_{4} \mathrm{~S}, 190.21 \mathrm{~g} / \mathrm{mol}, 561 \mathrm{mg}$, $2.95 \mathrm{mmol}$ ) to afford a clear colorless solution. After being stirred for $2 \mathrm{~h}$ at ambient temperature, the colorless solution was diluted by the addition of saturated aqueous $\mathrm{NaHCO}_{3}$ solution at ambient temperature. The resulting colorless biphasic mixture was transferred into a separatory funnel using $\mathrm{CH}_{2} \mathrm{Cl}_{2}$ for rinsing. The phases were separated, and the aqueous layer was extracted with $\mathrm{CH}_{2} \mathrm{Cl}_{2}(4 \times)$. The combined organic layers were dried $\left(\mathrm{MgSO}_{4}\right)$. Removal of all volatiles under reduced pressure and subsequent purification of the colorless oil by flash chromatography (cyclohexane-ethyl acetate, 500:1 to 100:1) delivered an inseparable mixture of diastereomers of (-)-8 $\left(\mathrm{C}_{24} \mathrm{H}_{41} \mathrm{ClO}_{4}, 429.04 \mathrm{~g} / \mathrm{mol}, 838 \mathrm{mg}\right.$, $1.95 \mathrm{mmol}, 66 \%, \mathrm{dr}=95: 5$ according to NMR evaluation) as a colorless oil. The ratio of diastereomers was determined by integration of the ${ }^{1} \mathrm{H}$ NMR signals at $3.86 \mathrm{ppm}$ (minor) and $3.95 \mathrm{ppm}$ (major). The absolute configuration of $20-\mathrm{CH}$ was tentatively assigned and later confirmed by the ${ }^{13} \mathrm{C}$ NMR acetonide analysis of Rychnovsky. $\mathrm{R}_{\mathrm{f}} 0.6$ (cyclohexane-ethyl acetate, $\left.1: 1\right) ;[\alpha]_{\mathrm{D}}{ }^{20}=-18.2\left(c=1, \mathrm{CHCl}_{3}\right) ; \mathrm{NMR}$ data are reported for the major diastereomer: ${ }^{1} \mathrm{H} \mathrm{NMR}\left(\mathrm{CDCl}_{3}, 500 \mathrm{MHz}\right) \delta 0.68(\mathrm{~d}, J=6.8 \mathrm{~Hz}, 3 \mathrm{H}), 0.94(\mathrm{~d}, J$ $=6.7 \mathrm{~Hz}, 3 \mathrm{H}), 0.98(\mathrm{~d}, J=6.8 \mathrm{~Hz}, 3 \mathrm{H}), 1.29(\mathrm{~s}, 3 \mathrm{H}), 1.31(\mathrm{~s}, 3 \mathrm{H}), 1.38(\mathrm{~s}, 3 \mathrm{H}), 1.46(\mathrm{~s}, 3 \mathrm{H}), 1.46-1.59$ (m, 4H), 1.87 (ddd, $J=13.9,9.6,2.6 \mathrm{~Hz}, 1 \mathrm{H}), 1.90-1.99(\mathrm{~m}, 2 \mathrm{H}), 1.99-2.10$ (m, 2H), 2.48 (apparent dsxt, $J=9.4,6.9 \mathrm{~Hz}, 1 \mathrm{H}), 3.24(\mathrm{dd}, J=7.9,1.8 \mathrm{~Hz}, 1 \mathrm{H}), 3.81(\mathrm{dd}, J=8.4,6.5 \mathrm{~Hz}, 1 \mathrm{H}), 3.95(\mathrm{ddd}, J=11.3$, $5.8,2.6 \mathrm{~Hz}, 1 \mathrm{H}), 4.08(\mathrm{dd}, J=8.4,6.7 \mathrm{~Hz}, 1 \mathrm{H}), 4.10(\mathrm{~d}, J=4.8 \mathrm{~Hz}, 1 \mathrm{H}), 4.23$ (apparent q, $J=6.3 \mathrm{~Hz}$, $1 \mathrm{H}), 4.95(\mathrm{~d}, J=10.1 \mathrm{~Hz}, 1 \mathrm{H}), 4.99(\mathrm{~d}, J=17.1 \mathrm{~Hz}, 1 \mathrm{H}), 5.23(\mathrm{~d}, J=9.5 \mathrm{~Hz}, 1 \mathrm{H}), 5.77$ (apparent ddt, $J=$ 17.1, 10.0, 7.2 Hz, $1 \mathrm{H}) ;{ }^{13} \mathrm{C} \mathrm{NMR}\left(\mathrm{CDCl}_{3}, 126 \mathrm{MHz}\right) \delta 12.6\left(\mathrm{CH}_{3}\right), 14.3\left(\mathrm{CH}_{3}\right), 14.9\left(\mathrm{CH}_{3}\right), 20.8\left(\mathrm{CH}_{3}\right)$, $24.1\left(\mathrm{CH}_{3}\right), 25.1\left(\mathrm{CH}_{3}\right), 25.4\left(\mathrm{CH}_{3}\right), 26.4\left(\mathrm{CH}_{3}\right), 32.2(\mathrm{CH}), 32.3(\mathrm{CH}), 35.9(\mathrm{CH}), 37.2\left(\mathrm{CH}_{2}\right), 41.9$ $\left(\mathrm{CH}_{2}\right), 61.2(\mathrm{CH}), 66.7\left(\mathrm{CH}_{2}\right), 72.3(\mathrm{CH}), 74.3(\mathrm{CH}), 79.1(\mathrm{CH}), 100.5(\mathrm{C}), 110.1(\mathrm{C}), 115.4\left(\mathrm{CH}_{2}\right), 130.1$ $(\mathrm{CH}), 130.7(\mathrm{C}), 137.8(\mathrm{CH})$; IR $v 2980(\mathrm{w}), 1640(\mathrm{w}), 1455(\mathrm{w}), 1380(\mathrm{~m}), 1220(\mathrm{~s}), 1170(\mathrm{~m}), 1055(\mathrm{~m})$, $1020(\mathrm{~m}), 960$ (w), $910(\mathrm{~m}), 855(\mathrm{~m}), 695$ (w), $510(\mathrm{w}) \mathrm{cm}^{-1}$; Anal. Calcd. for $\mathrm{C}_{24} \mathrm{H}_{41} \mathrm{ClO}_{4}$ : C, 67.2; H, 9.6; Found: C, 67.5; H, 9.7.

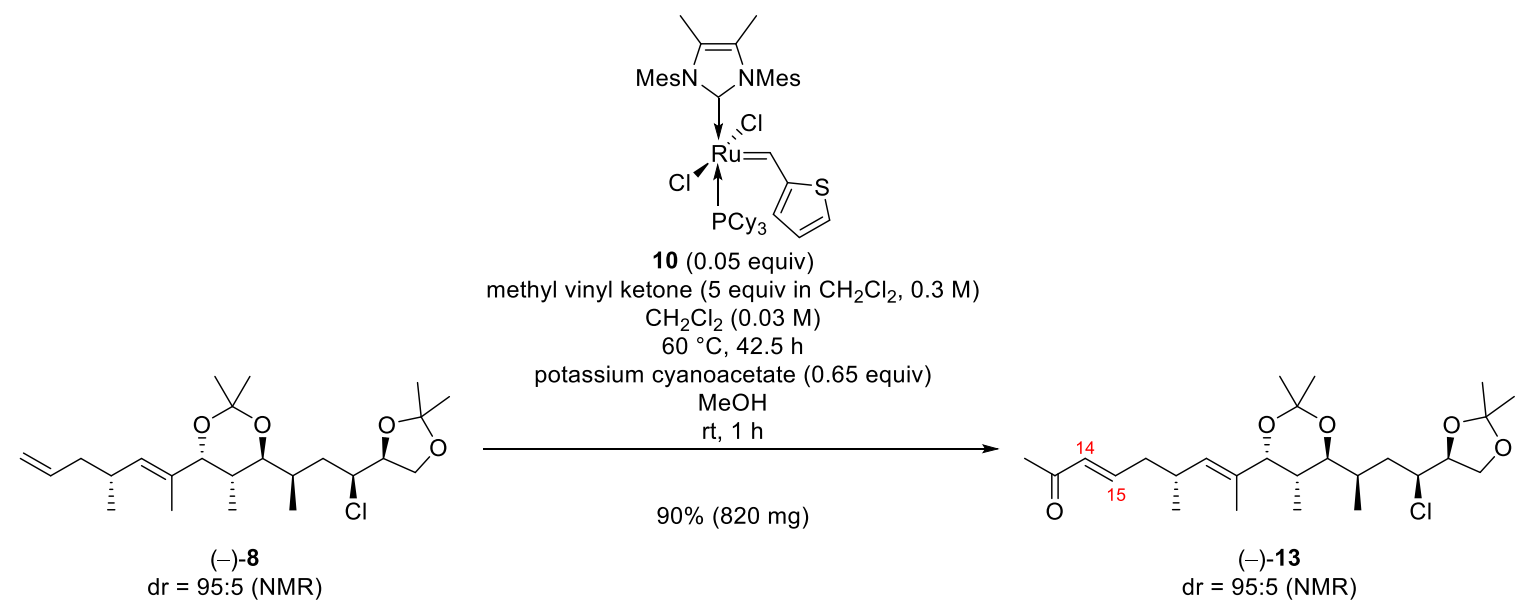

Enone (-)-13. A sealable glass pressure tube was charged with a diastereomeric mixture $(\mathrm{dr}=95: 5)$ of bis-acetal (-)-8 $\left(\mathrm{C}_{24} \mathrm{H}_{41} \mathrm{ClO}_{4}, 429.04 \mathrm{~g} / \mathrm{mol}, 828 \mathrm{mg}, 1.93 \mathrm{mmol}, 1\right.$ equiv) in $\mathrm{CH}_{2} \mathrm{Cl}_{2}(64.5 \mathrm{~mL}, 0.03 \mathrm{M}$, degassed by three freeze-pump-thaw-cycles) to afford a colorless solution. A solution of freshly distilled $\left(95^{\circ} \mathrm{C}\right)$ methyl vinyl ketone $\left(\mathrm{C}_{4} \mathrm{H}_{6} \mathrm{O}, 70.09 \mathrm{~g} / \mathrm{mol}, 0.864 \mathrm{~g} / \mathrm{mL}, 782 \mu \mathrm{L}, 676 \mathrm{mg}, 9.64 \mathrm{mmol}, 5\right.$ equiv) in $\mathrm{CH}_{2} \mathrm{Cl}_{2}$ (32 mL, 0.3 M, degassed by three freeze-pump-thaw-cycles) (overall: $0.02 \mathrm{M}$ in (-)-8 in $\mathrm{CH}_{2} \mathrm{Cl}_{2}$ ) and catMETium ${ }^{\circledR} \mathrm{RF} 310\left(\mathrm{C}_{46} \mathrm{H}_{65} \mathrm{Cl}_{2} \mathrm{~N}_{2} \mathrm{PRuS}, 881.04 \mathrm{~g} / \mathrm{mol}, 85 \mathrm{mg}, 96 \mu \mathrm{mol}, 0.05\right.$ equiv $)$ were added at ambient temperature to afford a brown solution. The tube was sealed with a Teflon screw cap and placed in a pre-heated oil bath $\left(60{ }^{\circ} \mathrm{C}\right)$. After being stirred for $42.5 \mathrm{~h}$ at $60{ }^{\circ} \mathrm{C}$, the resulting dark brown reaction mixture was cooled to ambient temperature and transferred into a round-bottomed flask using $\mathrm{CH}_{2} \mathrm{Cl}_{2}$ for rinsing. Removal of volatiles under reduced pressure $\left(40{ }^{\circ} \mathrm{C}, 640 \mathrm{mbar}\right)$ delivered a black liquid. Methanol $(38.5 \mathrm{~mL})$ and potassium cyanoacetate $\left(\mathrm{C}_{3} \mathrm{H}_{2} \mathrm{KNO}_{2}, 123.15 \mathrm{~g} / \mathrm{mol}, 181 \mathrm{mg}, 85 \%\right.$ purity, 154 
$\mathrm{mg}, 1.25 \mathrm{mmol}, 0.65$ equiv) were added and the resulting mixture was stirred at ambient temperature for 1 h. Removal of all volatiles under reduced pressure and subsequent purification of the black oil by flash chromatography (cyclohexane-ethyl acetate, 50:1 to 20:1) delivered an inseparable mixture of diastereomers of (-)-13 $\left(\mathrm{C}_{26} \mathrm{H}_{43} \mathrm{ClO}_{5}, 471.08 \mathrm{~g} / \mathrm{mol}, 820 \mathrm{mg}, 1.74 \mathrm{mmol}, 90 \%\right.$, $\mathrm{dr}=95: 5$ according to NMR evaluation) as a viscos colorless oil. The ratio of diastereomers was determined by integration of the ${ }^{1} \mathrm{H}$ NMR signals at $3.86 \mathrm{ppm}$ (minor) and $3.94 \mathrm{ppm}$ (major). The configuration of the $14-\mathrm{CH} / 15-\mathrm{CH}$ double bond was assigned by coupling constant analysis: 6.74 (apparent $\mathrm{dt}, J=15.1,7.4 \mathrm{~Hz}, 1 \mathrm{H}$ ). $\mathrm{R}_{\mathrm{f}} 0.66$ (cyclohexane-ethyl acetate, $1: 1) ;[\alpha]_{\mathrm{D}}^{20}=-40.1\left(c=1, \mathrm{CHCl}_{3}\right)$; NMR data are reported for the major diastereomer: ${ }^{1} \mathrm{H}$ NMR $\left(\mathrm{CDCl}_{3}, 500 \mathrm{MHz}\right) \delta 0.66(\mathrm{~d}, J=6.7 \mathrm{~Hz}, 3 \mathrm{H}), 0.94(\mathrm{dd}, J=6.2,6.2 \mathrm{~Hz}, 6 \mathrm{H}), 1.28$ $(\mathrm{s}, 3 \mathrm{H}), 1.31(\mathrm{~s}, 3 \mathrm{H}), 1.37(\mathrm{~s}, 3 \mathrm{H}), 1.45(\mathrm{~s}, 3 \mathrm{H}), 1.50-1.58(\mathrm{~m}, 4 \mathrm{H}), 1.86$ (ddd, $J=14.1,9.7,2.6 \mathrm{~Hz}, 1 \mathrm{H})$, 1.90-2.00 (m, 2H), 2.18-2.24 (m, 5H), 2.57 (apparent dsxt, $J=9.4,6.8 \mathrm{~Hz}, 1 \mathrm{H}), 3.24$ (dd, $J=7.8,1.7 \mathrm{~Hz}$, $1 \mathrm{H}), 3.80(\mathrm{dd}, J=8.5,6.4 \mathrm{~Hz}, 1 \mathrm{H}), 3.94(\mathrm{ddd}, J=11.3,5.7,2.6 \mathrm{~Hz}, 1 \mathrm{H}), 4.05-4.11(\mathrm{~m}, 2 \mathrm{H}), 4.22$ (apparent q, $J=6.3 \mathrm{~Hz}, 1 \mathrm{H}), 5.24(\mathrm{~d}, J=9.6 \mathrm{~Hz}, 1 \mathrm{H}), 6.05(\mathrm{~d}, J=15.9 \mathrm{~Hz}, 1 \mathrm{H}), 6.74$ (apparent dt, $J=$ 15.1, $7.4 \mathrm{~Hz}, 1 \mathrm{H}) ;{ }^{13} \mathrm{C} \mathrm{NMR}\left(\mathrm{CDCl}_{3}, 126 \mathrm{MHz}\right) \delta 12.5\left(\mathrm{CH}_{3}\right), 14.3\left(\mathrm{CH}_{3}\right), 14.9\left(\mathrm{CH}_{3}\right), 21.1\left(\mathrm{CH}_{3}\right), 24.1$ $\left(\mathrm{CH}_{3}\right), 25.1\left(\mathrm{CH}_{3}\right), 25.4\left(\mathrm{CH}_{3}\right), 26.4\left(\mathrm{CH}_{3}\right), 26.9\left(\mathrm{CH}_{3}\right), 31.8(\mathrm{CH}), 32.2(\mathrm{CH}), 35.7(\mathrm{CH}), 37.1\left(\mathrm{CH}_{2}\right)$, $40.4\left(\mathrm{CH}_{2}\right), 61.2(\mathrm{CH}), 66.7\left(\mathrm{CH}_{2}\right), 72.1(\mathrm{CH}), 74.2(\mathrm{CH}), 79.0(\mathrm{CH}), 100.6(\mathrm{C}), 110.1(\mathrm{C}), 129.0(\mathrm{CH})$, $131.7(\mathrm{C}), 132.3(\mathrm{CH}), 147.4(\mathrm{CH}), 198.9(\mathrm{C})$; IR $\vee 2985(\mathrm{w}), 1657(\mathrm{~m}), 1625(\mathrm{w}), 1455(\mathrm{w}), 1380(\mathrm{~m})$, $1250(\mathrm{~m}), 1220(\mathrm{~s}), 1170(\mathrm{~m}), 1055(\mathrm{~m}), 1020(\mathrm{~m}), 980(\mathrm{~m}), 885(\mathrm{~m}), 855(\mathrm{~m}), 695(\mathrm{w}), 545(\mathrm{w}), 510(\mathrm{w})$ $\mathrm{cm}^{-1}$; Anal. Calcd. for $\mathrm{C}_{26} \mathrm{H}_{43} \mathrm{ClO}_{5}$ : C, 66.3; H, 9.2; Found: C, 66.6; H, 9.1.
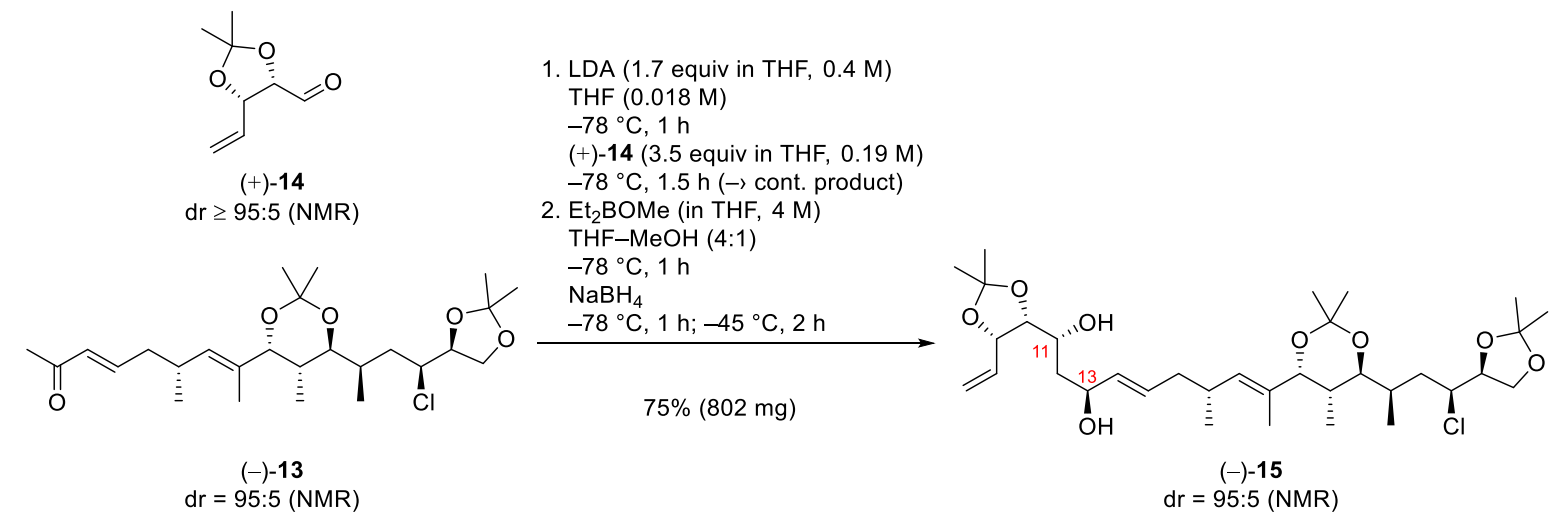

syn-11,13-Diol (-)-15. To a stirred solution of diisopropylamine (DIPA, $\mathrm{C}_{6} \mathrm{H}_{15} \mathrm{~N}, 101.19 \mathrm{~g} / \mathrm{mol}, 0.722$ $\mathrm{g} / \mathrm{mL}, 570 \mu \mathrm{L}, 412 \mathrm{mg}, 4.07 \mathrm{mmol})$ in THF $(7.5 \mathrm{~mL})$ at $-78{ }^{\circ} \mathrm{C}$ was added $n$-butyllithium $\left(\mathrm{C}_{4} \mathrm{H}_{9} \mathrm{Li}, 2.5 \mathrm{M}\right.$ in $n$-hexane, $1.53 \mathrm{~mL}, 3.83 \mathrm{mmol}$ ) to afford a colorless solution. After being stirred for $5 \mathrm{~min}$ at $-78{ }^{\circ} \mathrm{C}$, the solution was warmed to $0{ }^{\circ} \mathrm{C}$ and stirring was continued at $0{ }^{\circ} \mathrm{C}$ for $30 \mathrm{~min}$. A part of the resulting lithium diisopropylamide solution ( $\mathrm{LDA}, \mathrm{C}_{6} \mathrm{H}_{14} \mathrm{LiN}$, assumed to be $0.4 \mathrm{M}$ in THF- $n$-hexane $\{5: 1\}$ ) was used immediately according to the following procedure: A diastereomeric mixture $(\mathrm{dr}=95: 5)$ of enone $(-$ )-13 $\left(\mathrm{C}_{26} \mathrm{H}_{43} \mathrm{ClO}_{5}, 471.08 \mathrm{~g} / \mathrm{mol}, 798 \mathrm{mg}, 1.69 \mathrm{mmol}, 1\right.$ equiv) was dissolved in THF (95 mL, $\left.0.018 \mathrm{M}\right)$ and cooled to $-78{ }^{\circ} \mathrm{C}$. LDA $\left(\mathrm{C}_{6} \mathrm{H}_{14} \mathrm{LiN}\right.$, assumed to be $0.4 \mathrm{M}$ in THF-n-hexane $\{5: 1\}, 7.2 \mathrm{~mL}, 2.88$ mmol, 1.7 equiv) was added at $-78{ }^{\circ} \mathrm{C}$ to afford a colorless reaction mixture. After being stirred for $1 \mathrm{~h}$ at $-78{ }^{\circ} \mathrm{C}$, a solution of the freshly prepared aldehyde $(+)-14\left(\mathrm{C}_{8} \mathrm{H}_{12} \mathrm{O}_{3}, 77 \% \mathrm{~m} / \mathrm{m}\right.$ in diethyl ether, $1.21 \mathrm{~g}$ containing $932 \mathrm{mg}(+)-14,156.18 \mathrm{~g} / \mathrm{mol}, 5.97 \mathrm{mmol}, 3.5$ equiv) in THF (32 mL, $0.19 \mathrm{M}$ ) (overall: 0.013 $\mathrm{M}$ in (-)-13 in THF) was added dropwise at $-78{ }^{\circ} \mathrm{C}$ to afford a colorless reaction mixture. After being stirred for $1.5 \mathrm{~h}$ at $-78{ }^{\circ} \mathrm{C}$, the colorless reaction mixture was diluted by the slow addition of saturated aqueous $\mathrm{NH}_{4} \mathrm{Cl}$ solution at $-78{ }^{\circ} \mathrm{C}$. The resulting colorless biphasic mixture was transferred into a separatory funnel using diethyl ether for rinsing. The phases were separated, and the aqueous layer was extracted with $\mathrm{CH}_{2} \mathrm{Cl}_{2}(4 \times)$. The combined organic layers were dried $\left(\mathrm{MgSO}_{4}\right)$. Removal of all volatiles under reduced pressure and attempted purification of the colorless oil by flash chromatography (cyclohexane-ethyl acetate, 50:1 to 5:1) delivered a colorless oil (1.08 g). NMR analysis revealed significant but inseparable impurities of unconsumed aldehyde (+)-14, and, to avoid decomposition due to extensive chromatography, the colorless oil was used without further purification.

Note: The reaction was carried out in parallel in four batches. To four stirred solutions of the colorless oil 
$(1.08 \mathrm{~g}[4 \times 270 \mathrm{mg}])$ in $\mathrm{THF}(134 \mathrm{~mL}[4 \times 33.5 \mathrm{~mL}])$ and methanol $(34 \mathrm{~mL}[4 \times 8.5 \mathrm{~mL}])$ at $-78{ }^{\circ} \mathrm{C}$ was added diethylmethoxyborane ( $\mathrm{Et}_{2} \mathrm{BOMe}, \mathrm{C}_{5} \mathrm{H}_{13} \mathrm{BO}, 4 \mathrm{M}$ in THF, $1.696 \mathrm{~mL}$ [ $4 \times 424 \mu \mathrm{L}$ ], $6.78 \mathrm{mmol}$ ) to afford four colorless solutions. After being stirred for $1 \mathrm{~h}$ at $-78{ }^{\circ} \mathrm{C}$, sodium borohydride $\left(\mathrm{NaBH}_{4}, 37.83\right.$ $\mathrm{g} / \mathrm{mol}, 320 \mathrm{mg}$ [4×80 mg], $8.46 \mathrm{mmol}$ ) was added at $-78{ }^{\circ} \mathrm{C}$ to each solution to afford four colorless reaction mixtures. After being stirred at $-78{ }^{\circ} \mathrm{C}$ for $1 \mathrm{~h}$ and subsequently at $-45^{\circ} \mathrm{C}$ for $2 \mathrm{~h}$, the four colorless solutions were diluted by the addition of aqueous phosphate buffer $(\mathrm{pH} 7,108 \mathrm{~mL}[4 \times 27 \mathrm{~mL}])$, methanol $(108 \mathrm{~mL}[4 \times 27 \mathrm{~mL}])$, and hydrogen peroxide $(35 \% \mathrm{~m} / \mathrm{m}$ in water, $54 \mathrm{~mL}[4 \times 13.5 \mathrm{~mL}])$ at -78 ${ }^{\circ} \mathrm{C}$. The four colorless biphasic mixtures were allowed to warm to ambient temperature and were immediately transferred into a single beaker using $\mathrm{CH}_{2} \mathrm{Cl}_{2}$ for rinsing. The colorless biphasic mixture was diluted by the very slow addition of saturated aqueous $\mathrm{Na}_{2} \mathrm{~S}_{2} \mathrm{O}_{3}(216 \mathrm{~mL})$ solution at $0{ }^{\circ} \mathrm{C}$. The resulting colorless biphasic mixture was transferred into a separatory funnel using $\mathrm{CH}_{2} \mathrm{Cl}_{2}$ for rinsing. The phases were separated, and the aqueous layer was extracted with $\mathrm{CH}_{2} \mathrm{Cl}_{2}(5 \times)$. The combined organic layers were dried $\left(\mathrm{MgSO}_{4}\right)$. Removal of all volatiles under reduced pressure and subsequent purification of the remaining colorless oil by flash chromatography (cyclohexane-ethyl acetate, 20:1 to 5:1) delivered an inseparable mixture of diastereomers of $(-)-\mathbf{1 5}\left(\mathrm{C}_{34} \mathrm{H}_{57} \mathrm{ClO}_{8}, 629.27 \mathrm{~g} / \mathrm{mol}, 802 \mathrm{mg}, 1.27 \mathrm{mmol}, 75 \%, \mathrm{dr}=\right.$ 95:5 according to NMR evaluation) as a viscos colorless oil. The ratio of diastereomers was determined by integration of the ${ }^{1} \mathrm{H}$ NMR signals at $4.22 \mathrm{ppm}$ (major) and $4.28 \mathrm{ppm}$ (minor). The absolute configuration of 11-CH and 13-CH was assigned in analogy to the stereochemical course of the synthesis of the syn-11,13-diol (-)-S14. $\mathrm{R}_{\mathrm{f}} 0.51$ (cyclohexane-ethyl acetate, $\left.1: 1\right) ;[\alpha]_{\mathrm{D}}{ }^{20}=-7.7\left(c=1, \mathrm{CHCl}_{3}\right)$; NMR data are reported for the major diastereomer: ${ }^{1} \mathrm{H}$ NMR $\left(\mathrm{CDCl}_{3}, 500 \mathrm{MHz}\right) \delta 0.67(\mathrm{~d}, J=6.7 \mathrm{~Hz}$, $3 \mathrm{H}), 0.93(\mathrm{~d}, J=6.7 \mathrm{~Hz}, 3 \mathrm{H}), 0.98(\mathrm{~d}, J=6.8 \mathrm{~Hz}, 3 \mathrm{H}), 1.28(\mathrm{~s}, 3 \mathrm{H}), 1.31(\mathrm{~s}, 3 \mathrm{H}), 1.36(\mathrm{~s}, 3 \mathrm{H}), 1.37(\mathrm{~s}$, $3 \mathrm{H}), 1.45$ (s, 3H), $1.47(\mathrm{~s}, 3 \mathrm{H}), 1.49-1.58(\mathrm{~m}, 4 \mathrm{H}), 1.63$ (apparent dt, $J=14.6,10.0 \mathrm{~Hz}, 1 \mathrm{H}), 1.86$ (ddd, $J$ $=13.6,9.9,2.4 \mathrm{~Hz}, 1 \mathrm{H}), 1.90-2.06(\mathrm{~m}, 5 \mathrm{H}), 2.37$ (br. s, 1H), 2.44 (apparent dsxt, $J=9.2,6.9 \mathrm{~Hz}, 1 \mathrm{H})$, 3.23 (dd, $J=7.8,1.5 \mathrm{~Hz}, 1 \mathrm{H}$ ), 3.33 (br. s, $1 \mathrm{H}$ ), 3.80 (dd, $J=8.5,6.4 \mathrm{~Hz}, 1 \mathrm{H}$ ), 3.89 (ddd, $J=9.8,8.5,1.1$ $\mathrm{Hz}, 1 \mathrm{H}), 3.92-3.98(\mathrm{~m}, 2 \mathrm{H}), 4.05-4.10(\mathrm{~m}, 2 \mathrm{H}), 4.22$ (apparent q, $J=6.3 \mathrm{~Hz}, 1 \mathrm{H}), 4.35$ (ddd, $J=9.6,6.4$, $2.4 \mathrm{~Hz}, 1 \mathrm{H}), 4.67$ (apparent t, $J=6.6 \mathrm{~Hz}, 1 \mathrm{H}), 5.21(\mathrm{~d}, J=9.5 \mathrm{~Hz}, 1 \mathrm{H}), 5.30(\mathrm{~d}, J=10.5 \mathrm{~Hz}, 1 \mathrm{H}), 5.43(\mathrm{~d}$, $J=17.1 \mathrm{~Hz}, 1 \mathrm{H}), 5.48(\mathrm{dd}, J=15.4,6.9 \mathrm{~Hz}, 1 \mathrm{H}), 5.62$ (apparent dt, $J=14.7,7.0 \mathrm{~Hz}, 1 \mathrm{H}), 6.05$ (ddd, $J=$ 17.2, 10.3, 7.0 Hz, 1H); ${ }^{13} \mathrm{C} \mathrm{NMR}\left(\mathrm{CDCl}_{3}, 126 \mathrm{MHz}\right) \delta 12.6\left(\mathrm{CH}_{3}\right), 14.4\left(\mathrm{CH}_{3}\right), 14.9\left(\mathrm{CH}_{3}\right), 20.8\left(\mathrm{CH}_{3}\right)$, $24.1\left(\mathrm{CH}_{3}\right), 25.2\left(\mathrm{CH}_{3}\right), 25.4\left(\mathrm{CH}_{3}\right), 25.5\left(\mathrm{CH}_{3}\right), 26.4\left(\mathrm{CH}_{3}\right), 27.9\left(\mathrm{CH}_{3}\right), 32.1(\mathrm{CH}), 32.3(\mathrm{CH}), 35.7$ $(\mathrm{CH}), 37.1\left(\mathrm{CH}_{2}\right), 40.1\left(\mathrm{CH}_{2}\right), 40.3\left(\mathrm{CH}_{2}\right), 61.2(\mathrm{CH}), 66.7\left(\mathrm{CH}_{2}\right), 70.9(\mathrm{CH}), 72.2(\mathrm{CH}), 74.0(\mathrm{CH}), 74.2$ $(\mathrm{CH}), 78.9(\mathrm{CH}), 79.1(\mathrm{CH}), 80.6(\mathrm{CH}), 100.6(\mathrm{C}), 108.8(\mathrm{C}), 110.1(\mathrm{C}), 118.2\left(\mathrm{CH}_{2}\right), 129.9(\mathrm{CH}), 130.8$ (C), $130.8(\mathrm{CH}), 133.6(\mathrm{CH}), 134.6(\mathrm{CH})$; IR $\vee 3430(\mathrm{w}), 2985(\mathrm{~m}), 2915(\mathrm{w}), 2875(\mathrm{w}), 1740(\mathrm{w}), 1455$ (w), 1370 (s), 1220 (s), $1170(\mathrm{~m}), 1120$ (m), 1055 (s), 970 (m), 925 (m), $875(\mathrm{~m}), 855(\mathrm{~m}), 695(\mathrm{w}), 510$ (m) $\mathrm{cm}^{-1}$; HRMS (ESI): $\mathrm{m} / \mathrm{z}[\mathrm{M}+\mathrm{Na}]^{+}$Calcd. for $\mathrm{C}_{34} \mathrm{H}_{57} \mathrm{ClNaO}_{8}$ : 651.36342; Found: 651.36350 .

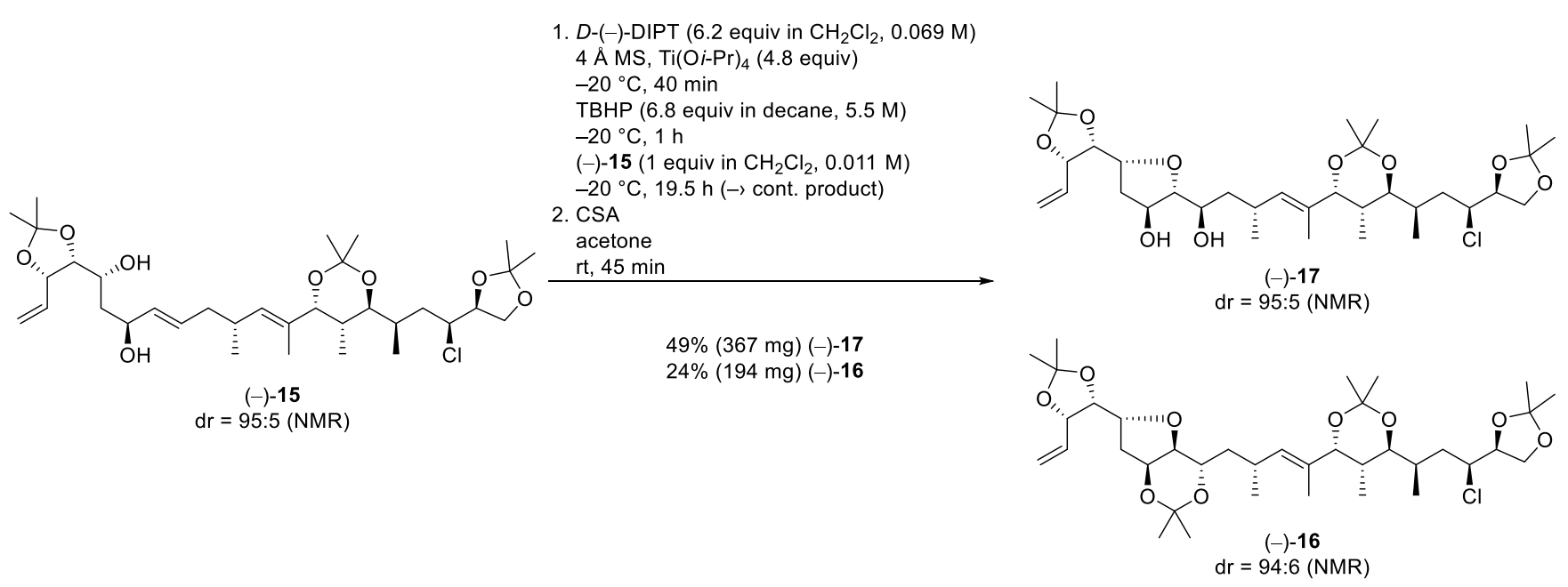

Tetrahydrofurane (-)-17 and Tetrakis-acetal (-)-16. Note: The reaction was carried out in parallel in four batches. To four colorless solutions of freshly distilled (0.05 mbar, $\left.150{ }^{\circ} \mathrm{C}\right) \mathrm{D}$-(-)-diisopropyl tartrate $\left(D-(-)\right.$-DIPT, $\mathrm{C}_{10} \mathrm{H}_{18} \mathrm{O}_{6}, 234.25 \mathrm{~g} / \mathrm{mol}, 1.119 \mathrm{~g} / \mathrm{mL}, 1.524 \mathrm{~mL}[4 \times 381 \mu \mathrm{L}], 1.705 \mathrm{~g}$ [4×426 mg], 7.27 
mmol, 6.2 equiv) in $\mathrm{CH}_{2} \mathrm{Cl}_{2}(105 \mathrm{~mL}$ [4×26.25 mL], $0.069 \mathrm{M})$ at ambient temperature was added powdered $4 \AA$ molecular sieves $(2.944 \mathrm{~g}$ [4×736 mg], $4 \mathrm{mg} / \mathrm{mg}(-)-15)$ to afford four slightly orange suspensions. The four suspensions were cooled to $-20{ }^{\circ} \mathrm{C}$ and freshly distilled $\left(1 \mathrm{mbar}, 125{ }^{\circ} \mathrm{C}\right)$ titanium(IV) isopropoxide ( $\mathrm{Ti}(\mathrm{O} i-\mathrm{Pr})_{4}, \mathrm{C}_{12} \mathrm{H}_{18} \mathrm{O}_{4} \mathrm{Ti}, 284.22 \mathrm{~g} / \mathrm{mol}, 0.96 \mathrm{~g} / \mathrm{mL}, 1.654 \mathrm{~mL}$ [4×413.5 $\mu \mathrm{L}$ ],

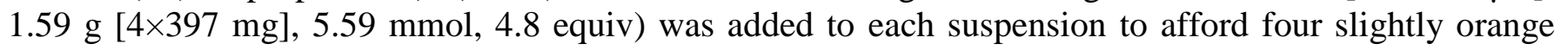
suspension. After being stirred for $40 \mathrm{~min}$ at $-20{ }^{\circ} \mathrm{C}$, tert-butyl hydroperoxide (TBHP, $\mathrm{C}_{4} \mathrm{H}_{10} \mathrm{O}_{2}, 5.5 \mathrm{M}$ in decane, $1.444 \mathrm{~mL}\left[4 \times 361 \mu \mathrm{L}\right.$ ], $7.94 \mathrm{mmol}, 6.8$ equiv) was added dropwise at $-20{ }^{\circ} \mathrm{C}$ to each suspension and stirring was continued at $-20{ }^{\circ} \mathrm{C}$ for $1 \mathrm{~h}$. A diastereomeric mixture $(\mathrm{dr}=95: 5)$ of syn-11,13-diol (-)$15\left(\mathrm{C}_{34} \mathrm{H}_{57} \mathrm{ClO}_{8}, 629.27 \mathrm{~g} / \mathrm{mol}, 736 \mathrm{mg}\right.$ [4×184 mg], $1.17 \mathrm{mmol}, 1$ equiv) dissolved in $\mathrm{CH}_{2} \mathrm{Cl}_{2}(105 \mathrm{~mL}$ [4×26.25 mL], $0.011 \mathrm{M}$; overall: $0.006 \mathrm{M}$ in $\mathrm{CH}_{2} \mathrm{Cl}_{2}$ ) was added dropwise at $-20{ }^{\circ} \mathrm{C}$ to each suspension to afford four orange suspensions. After being stirred at $-20^{\circ} \mathrm{C}$ for $19.5 \mathrm{~h}$, the four orange suspensions were diluted by the addition of aqueous $\mathrm{NaOH}$ solution $(3 \mathrm{~N})$ at $-20{ }^{\circ} \mathrm{C}$. The resulting four orange biphasic mixtures were allowed to warm to ambient temperature. After being stirred for $15 \mathrm{~min}$ at ambient temperature, saturated aqueous $\mathrm{Na}_{2} \mathrm{~S}_{2} \mathrm{O}_{3}$ solution was added and stirring was continued for 15 min. Solid potassium sodium tartrate was added and stirring continued for $15 \mathrm{~min}$ at ambient temperature. The resulting four orange biphasic mixtures were diluted further by the addition of methanol $(10.4 \mathrm{~mL}[4 \times 2.6$ $\mathrm{mL}]$ ) at ambient temperature. The resulting four orange biphasic mixtures were transferred into a single separatory funnel using $\mathrm{CH}_{2} \mathrm{Cl}_{2}$ for rinsing. The phases were separated, and the aqueous layer was extracted with $\mathrm{CH}_{2} \mathrm{Cl}_{2}(5 \times)$. The combined organic layers were dried $\left(\mathrm{MgSO}_{4}\right)$. Removal of all volatiles under reduced pressure and attempted purification of the cloudy colorless oil by flash chromatography (cyclohexane-ethyl acetate, 10:1 to 1:1) delivered a clear colorless oil (1.07 g). NMR analysis revealed significant but inseparable impurities of $D-(-)$-DIPT and $\mathrm{Ti}(\mathrm{O} i \text {-Pr })_{4}$, and the clear colorless oil was used without further purification.

To a stirred solution of the clear colorless oil $(1.07 \mathrm{~g})$ in acetone $(117 \mathrm{~mL})$ at ambient temperature was added (+)-camphor-10-sulfonic acid (CSA, $\left.\mathrm{C}_{10} \mathrm{H}_{16} \mathrm{O}_{4} \mathrm{~S}, 232.3 \mathrm{~g} / \mathrm{mol}, 325 \mathrm{mg}, 1.4 \mathrm{mmol}\right)$ to afford a clear colorless solution. After being stirred at ambient temperature for $40 \mathrm{~min}$, the clear colorless solution was diluted by the addition of aqueous phosphate buffer $(\mathrm{pH} 7)$ at ambient temperature. The resulting colorless biphasic mixture was transferred into a separatory funnel using $\mathrm{CH}_{2} \mathrm{Cl}_{2}$ for rinsing. The phases were separated, and the aqueous layer was extracted with $\mathrm{CH}_{2} \mathrm{Cl}_{2}(5 \times)$. The combined organic layers were dried $\left(\mathrm{MgSO}_{4}\right)$. Removal of all volatiles under reduced pressure and subsequent purification of the colorless oil by flash chromatography (cyclohexane-ethyl acetate, 10:1 to 1:1) yielded an inseparable mixture of diastereomers of (-)-17 $\left(\mathrm{C}_{34} \mathrm{H}_{57} \mathrm{ClO}_{9}, 645.27 \mathrm{~g} / \mathrm{mol}, 367 \mathrm{mg}, 569 \mu \mathrm{mol}, 49 \%\right.$, $\mathrm{dr}=95: 5$ according to NMR evaluation) as a clear colorless oil, and an inseparable mixture of diastereomers of (-)-16 $\left(\mathrm{C}_{37} \mathrm{H}_{61} \mathrm{ClO}_{9}, 685.34 \mathrm{~g} / \mathrm{mol}, 194 \mathrm{mg}, 283 \mu \mathrm{mol}, 24 \%\right.$, dr = 94:6 according to NMR evaluation $)$ as a clear colorless oil.
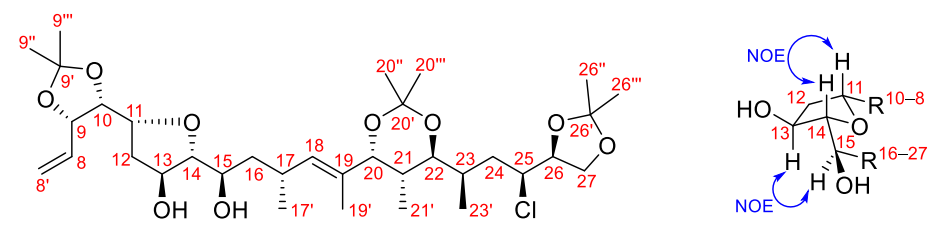

$(-)-17$

Table SI-1-2. Assignment of the absolute configuration for (-)-17.

\begin{tabular}{cc}
\hline carbon atom & foundation for assignment \\
\hline $9-\mathrm{CH}$ & ex-chiral-pool synthesis \\
$10-\mathrm{CH}$ & ex-chiral-pool synthesis \\
$11-\mathrm{CH}$ & analogy to (-)-S14 (Table SI-1-1) \\
$13-\mathrm{CH}$ & analogy to (-)-S14 (Table SI-1-1) \\
$14-\mathrm{CH}$ & asymmetric synthesis: applying the accepted stereochemical model for the Sharpless \\
& asymmetric epoxidation (SAE) and assuming a diastereospecific 5-exo-tet-
\end{tabular}


tetrahydrofurane ring formation by concerted $S_{N}$ ring opening of the epoxide; NMR spectroscopy: NOE correlation experimentally observed between $13-\mathrm{CH}$ and $15-\mathrm{CH}, 12-$ $\mathrm{CH}_{2}{ }^{S i}$ and $13-\mathrm{CH}, 14-\mathrm{CH}$ and $11-\mathrm{CH}, 12-\mathrm{CH}_{2}{ }^{R e}$ and $11-\mathrm{CH}$

15- $\mathrm{CH} \quad$ asymmetric synthesis: applying the accepted stereochemical model for the Sharpless asymmetric epoxidation (SAE) and assuming a diastereospecific 5-exo-tet-

tetrahydrofurane ring formation by concerted $S_{N}$ ring opening of the epoxide; NMR spectroscopy: NOE experiment

17-CH asymmetric synthesis: applying accepted stereochemical model for asymmetric induction by chiral auxiliary; in accordance to the literature; no independent verification by spectroscopy or crystallography

20-CH $\quad{ }^{13} \mathrm{C}$ NMR chemical shifts of (-)-17 for the acetonide at 20-CH and 22-CH suggest a 20,22-anti configuration (Figure SI-1-6) and, therefore, supports the assumption of a $(20 R)$-configuration

$21-\mathrm{CH}$

$22-\mathrm{CH}$

$23-\mathrm{CH}$

$25-\mathrm{CH}$ analogy to (-)-12 (Table SI-1-1)

analogy to (-)-12 (Table SI-1-1)

asymmetric synthesis: applying accepted stereochemical model for asymmetric induction by chiral auxiliary; in accordance to the literature; no independent verification by spectroscopy or crystallography independent verification by spectroscopy or crystallography

$(-)-17\left(\mathrm{C}_{34} \mathrm{H}_{57} \mathrm{ClO}_{9}\right)$ : The ratio of diastereomers was determined by integration of the ${ }^{1} \mathrm{H}$ NMR signals at $3.13 \mathrm{ppm}$ (minor) and $3.23 \mathrm{ppm}$ (major). $\mathrm{R}_{\mathrm{f}} 0.37$ (cyclohexane-ethyl acetate, $\left.1: 1\right) ;[\alpha]_{\mathrm{D}}^{25}=-1.5(c=1$, $\left.\mathrm{CHCl}_{3}\right)$; NMR data are reported for the major diastereomer: ${ }^{1} \mathrm{H} \mathrm{NMR}\left(\mathrm{CDCl}_{3}, 400 \mathrm{MHz}\right) \delta 0.66(\mathrm{~d}, J=$ $\left.6.8 \mathrm{~Hz}, 3 \mathrm{H}, 21^{\prime}-\mathrm{CH}_{3}\right), 0.94-1.00\left(\mathrm{~m}, 6 \mathrm{H}, 17^{\prime}-\mathrm{CH}_{3}+23^{\prime}-\mathrm{CH}_{3}\right), 1.27$ (s, 3H, 20"- $\mathrm{CH}_{3}$ or 20'"- $\left.\mathrm{CH}_{3}\right), 1.30$ (s,

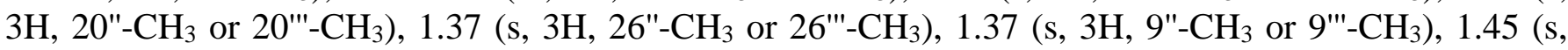
$3 \mathrm{H}, 26 "-\mathrm{CH}_{3}$ or $\left.26^{\prime \prime \prime}-\mathrm{CH}_{3}\right), 1.46-1.52\left(\mathrm{~m}, 4 \mathrm{H}, 9{ }^{\prime \prime}-\mathrm{CH}_{3}\right.$ or 9'"- $\left.\mathrm{CH}_{3}+16-\mathrm{CH}_{2}\right), 1.52-1.62(\mathrm{~m}, 5 \mathrm{H}, 19 '-$ $\left.\mathrm{CH}_{3}+16-\mathrm{CH}_{2}+24-\mathrm{CH}_{2}\right), 1.82-2.01$ (m, 4H, 12- $\left.\mathrm{CH}_{2}+24-\mathrm{CH}_{2}+21-\mathrm{CH}+23-\mathrm{CH}\right), 2.03-2.18$ (m, 2H, 12$\mathrm{CH}_{2}+-\mathrm{OH}$ ), 2.65 (apparent dsxt, $J=9.4,7.1 \mathrm{~Hz}, 1 \mathrm{H}, 17-\mathrm{CH}$ ), 2.75 (br. s, $\left.1 \mathrm{H},-\mathrm{OH}\right), 3.23$ (dd, $J=7.8,1.9$ $\mathrm{Hz}, 1 \mathrm{H}, 22-\mathrm{CH}), 3.58$ (dd, $J=4.4,3.2 \mathrm{~Hz}, 1 \mathrm{H}, 14-\mathrm{CH}), 3.71$ (apparent dt, $J=8.6,4.3 \mathrm{~Hz}, 1 \mathrm{H}, 15-\mathrm{CH}$ ), $3.80\left(\mathrm{dd}, J=8.5,6.4 \mathrm{~Hz}, 1 \mathrm{H}, 27-\mathrm{CH}_{2}\right), 3.94(\mathrm{ddd}, J=11.2,5.7,2.7 \mathrm{~Hz}, 1 \mathrm{H}, 25-\mathrm{CH}), 4.03-4.10(\mathrm{~m}, 2 \mathrm{H}$, $27-\mathrm{CH}+20-\mathrm{CH}), 4.15$ (ddd, $J=8.6,6.5,4.7 \mathrm{~Hz}, 1 \mathrm{H}, 11-\mathrm{CH}), 4.22$ (apparent q, $J=6.3 \mathrm{~Hz}, 1 \mathrm{H}, 26-\mathrm{CH}$ ), $4.31(\mathrm{dd}, J=7.2,4.7 \mathrm{~Hz}, 1 \mathrm{H}, 10-\mathrm{CH}), 4.39$ (apparent dt, $J=6.3,2.7 \mathrm{~Hz}, 1 \mathrm{H}, 13-\mathrm{CH}), 4.68$ (apparent t, $J=$ $7.0 \mathrm{~Hz}, 1 \mathrm{H}, 9-\mathrm{CH}$ ), 5.25 (apparent dt, $J=10.4,1.3 \mathrm{~Hz}, 1 \mathrm{H}, 8^{\prime}-\mathrm{CH}$ ), 5.33 (apparent dt, $J=9.8,1.4 \mathrm{~Hz}, 1 \mathrm{H}$, $18-\mathrm{CH}$ ), 5.38 (apparent dt, $\left.J=17.1,1.4 \mathrm{~Hz}, 1 \mathrm{H}, 8{ }^{\prime}-\mathrm{CH}\right), 5.83$ (ddd, $J=17.1,10.4,6.8 \mathrm{~Hz}, 1 \mathrm{H}, 8-\mathrm{CH}$ ); ${ }^{13} \mathrm{C}$ $\mathrm{NMR}\left(\mathrm{CDCl}_{3}, 101 \mathrm{MHz}\right) \delta 12.6\left(21^{\prime}-\mathrm{CH}_{3}\right), 14.5\left(19^{\prime}-\mathrm{CH}_{3}\right), 14.9\left(23^{\prime}-\mathrm{CH}_{3}\right), 21.1\left(17^{\prime}-\mathrm{CH}_{3}\right), 24.0\left(20 "-\mathrm{CH}_{3}\right.$

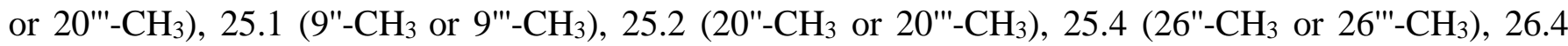

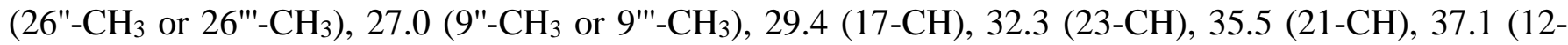
$\mathrm{CH}_{2}$ or $\left.24-\mathrm{CH}_{2}\right), 37.2\left(12-\mathrm{CH}_{2}\right.$ or $\left.24-\mathrm{CH}_{2}\right), 41.0\left(16-\mathrm{CH}_{2}\right), 61.1(25-\mathrm{CH}), 66.6\left(27-\mathrm{CH}_{2}\right), 71.8(15-\mathrm{CH})$, $72.1(20-\mathrm{CH}), 73.1(13-\mathrm{CH}), 74.3(22-\mathrm{CH}), 77.4(11-\mathrm{CH}), 78.1(9-\mathrm{CH}), 79.0(26-\mathrm{CH}), 79.7(10-\mathrm{CH}), 89.4$ (14-CH), 100.6 (20'-C), 108.8 (9'-C), 110.1 (26'-C), 118.5 (8'-CH $), 130.4$ (18-CH), 131.4 (19-C), 133.6 (8-CH); IR v $3460(\mathrm{w}), 2930$ (m), 1740 (w), 1455 (w), 1370 (s), 1220 (s), 1170 (m), 1055 (s), 930 (m), 875 (m), 695 (w), 515 (w) $\mathrm{cm}^{-1}$; Anal. Calcd. for $\mathrm{C}_{34} \mathrm{H}_{57} \mathrm{ClO}_{9}$ : C, 63.3; H, 8.9; Found: C, 63.3; H, 9.1; HRMS (ESI): $\mathrm{m} / \mathrm{z}[\mathrm{M}+\mathrm{Na}]^{+}$Calcd. for $\mathrm{C}_{34} \mathrm{H}_{57} \mathrm{ClNaO}_{9}$ : 667.35833; Found: 667.35823.
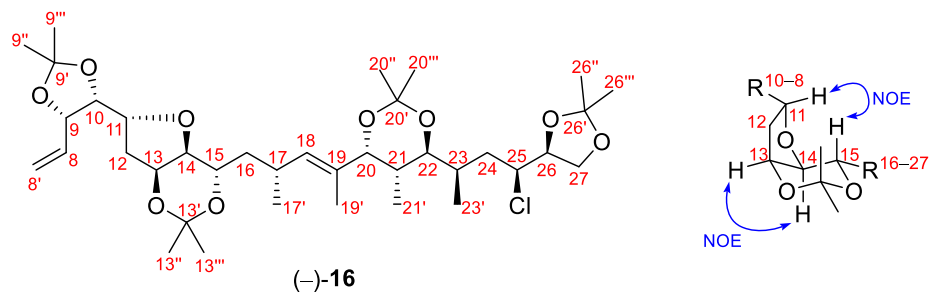
Table SI-1-3. Assignment of the absolute configuration for (-)-16.

\begin{tabular}{|c|c|}
\hline carbon atom & foundation for assignment \\
\hline 9-CH & ex-chiral-pool synthesis \\
\hline $10-\mathrm{CH}$ & ex-chiral-pool synthesis \\
\hline $11-\mathrm{CH}$ & analogy to (-)-S14 (Table SI-1-1) \\
\hline $13-\mathrm{CH}$ & analogy to (-)-S14 (Table SI-1-1) \\
\hline $14-\mathrm{CH}$ & $\begin{array}{l}\text { asymmetric synthesis: applying the accepted stereochemical model for the Sharpless } \\
\text { asymmetric epoxidation (SAE) and assuming a diastereospecific 5-exo-tet- } \\
\text { tetrahydrofurane ring formation by concerted } \mathrm{S}_{\mathrm{Ni}} \text { ring opening of the epoxide; NMR } \\
\text { spectroscopy: NOE correlation experimentally observed between } 13-\mathrm{CH} \text { and } 14-\mathrm{CH}, 13- \\
\mathrm{CH} \text { and } 12-\mathrm{CH}_{2} \mathrm{Re}, 11-\mathrm{CH} \text { and } 15-\mathrm{CH}, 11-\mathrm{CH} \text { and } 12-\mathrm{CH}_{2}{ }^{\mathrm{Si}}\end{array}$ \\
\hline $15-\mathrm{CH}$ & $\begin{array}{l}\text { asymmetric synthesis: applying the accepted stereochemical model for the Sharpless } \\
\text { asymmetric epoxidation (SAE) and assuming a diastereospecific 5-exo-tet- } \\
\text { tetrahydrofurane ring formation by concerted } \mathrm{S}_{\mathrm{N}} \text { ring opening of the epoxide; NMR } \\
\text { spectroscopy: NOE experiment; }{ }^{13} \mathrm{C} \text { NMR chemical shifts of }(-)-16 \text { for the acetonide at } \\
\text { 13-CH and 15-CH suggest a } 13,15 \text {-anti configuration (Figure SI-1-7) and, therefore, } \\
\text { supports the assumption of a }(15 S) \text {-configuration }\end{array}$ \\
\hline $17-\mathrm{CH}$ & $\begin{array}{l}\text { asymmetric synthesis: applying accepted stereochemical model for asymmetric induction } \\
\text { by chiral auxiliary; in accordance to the literature; no independent verification by } \\
\text { spectroscopy or crystallography }\end{array}$ \\
\hline 20-CH & analogy to $(-)-17$ (Table SI-1-2) \\
\hline 21-CH & analogy to (-)-12 (Table SI-1-1) \\
\hline 22- $\mathrm{CH}$ & analogy to (-)-12 (Table SI-1-1) \\
\hline $23-\mathrm{CH}$ & $\begin{array}{l}\text { asymmetric synthesis: applying accepted stereochemical model for asymmetric induction } \\
\text { by chiral auxiliary; in accordance to the literature; no independent verification by } \\
\text { spectroscopy or crystallography }\end{array}$ \\
\hline $25-\mathrm{CH}$ & $\begin{array}{l}\text { ex-chiral-pool synthesis and diastereospecific } \mathrm{S}_{\mathrm{N}} 2 \text {; in accordance to the literature; no } \\
\text { independent verification by spectroscopy or crystallography }\end{array}$ \\
\hline 26- $\mathrm{CH}$ & ex-chiral-pool synthesis \\
\hline
\end{tabular}

$(-)-16\left(\mathrm{C}_{37} \mathrm{H}_{61} \mathrm{ClO}_{9}\right)$ : The ratio of diastereomers was determined by integration of the ${ }^{1} \mathrm{H}$ NMR signals at $4.22 \mathrm{ppm}$ (major) and $4.28 \mathrm{ppm}$ (minor). $\mathrm{R}_{\mathrm{f}} 0.77$ (cyclohexane-ethyl acetate, $\left.1: 1\right) ;[\alpha]_{\mathrm{D}}{ }^{20}=-3.3(c=1$, $\left.\mathrm{CHCl}_{3}\right)$; NMR data are reported for the major diastereomer: ${ }^{1} \mathrm{H} \mathrm{NMR}\left(\mathrm{CDCl}_{3}, 500 \mathrm{MHz}\right) \delta 0.68(\mathrm{~d}, J=$ $\left.6.7 \mathrm{~Hz}, 3 \mathrm{H}, 21^{\prime}-\mathrm{CH}_{3}\right), 0.94\left(\mathrm{~d}, J=6.8 \mathrm{~Hz}, 3 \mathrm{H}, 17^{\prime}-\mathrm{CH}_{3}\right), 0.98\left(\mathrm{~d}, J=6.8 \mathrm{~Hz}, 3 \mathrm{H}, 23^{\prime}-\mathrm{CH}_{3}\right), 1.23(\mathrm{~s}, 3 \mathrm{H}$, 13 "- $\mathrm{CH}_{3}$ or 13 '"- $\left.\mathrm{CH}_{3}\right), 1.28$ (s, $3 \mathrm{H}, 20$ "- $\mathrm{CH}_{3}$ or 20 '"- $\left.\mathrm{CH}_{3}\right), 1.30-1.33$ (m, $6 \mathrm{H}, 13$ "- $\mathrm{CH}_{3}$ or 13 "'- $\mathrm{CH}_{3}+20$ "$\mathrm{CH}_{3}$ or 20 "'- $\left.\mathrm{CH}_{3}\right), 1.35-1.38\left(\mathrm{~m}, 6 \mathrm{H}, 9\right.$ "- $\mathrm{CH}_{3}$ or 9"'- $\mathrm{CH}_{3}+26$ "- $\mathrm{CH}_{3}$ or 26 '"- $\left.\mathrm{CH}_{3}\right), 1.41-1.50$ (m, 7H, 9"-- $\mathrm{CH}_{3}$ or 9'"- $\mathrm{CH}_{3}+26$ "- $\mathrm{CH}_{3}$ or 26 '"- $\left.\mathrm{CH}_{3}+16-\mathrm{CH}_{2}\right), 1.50-1.61\left(\mathrm{~m}, 5 \mathrm{H}, 19\right.$ '- $\left.\mathrm{CH}_{3}+16-\mathrm{CH}_{2}+24-\mathrm{CH}_{2}\right), 1.82-1.90(\mathrm{~m}$, $\left.2 \mathrm{H}, 12-\mathrm{CH}_{2}+24-\mathrm{CH}_{2}\right), 1.90-2.00(\mathrm{~m}, 2 \mathrm{H}, 21-\mathrm{CH}+23-\mathrm{CH}), 2.09$ (dd, $\left.J=13.4,3.2 \mathrm{~Hz}, 1 \mathrm{H}, 12-\mathrm{CH}_{2}\right), 2.60$ $2.71(\mathrm{~m}, 1 \mathrm{H}, 17-\mathrm{CH}), 3.24(\mathrm{dd}, J=6.7,1.0 \mathrm{~Hz}, 1 \mathrm{H}, 22-\mathrm{CH}), 3.38$ (apparent td, $J=9.2,1.9 \mathrm{~Hz}, 1 \mathrm{H}, 15-$ $\mathrm{CH}), 3.77-3.85\left(\mathrm{~m}, 2 \mathrm{H}, 14-\mathrm{CH}+27-\mathrm{CH}_{2}\right), 3.94(\mathrm{ddd}, J=11.2,5.6,2.4 \mathrm{~Hz}, 1 \mathrm{H}, 25-\mathrm{CH}), 3.99-4.04(\mathrm{~m}, 2 \mathrm{H}$, $10-\mathrm{CH}+, 11-\mathrm{CH}), 4.05-4.09\left(\mathrm{~m}, 2 \mathrm{H}, 20-\mathrm{CH}+27-\mathrm{CH}_{2}\right), 4.22$ (apparent q, $\left.J=6.2 \mathrm{~Hz}, 1 \mathrm{H}, 26-\mathrm{CH}\right), 4.38$ (apparent t, $J=5.4 \mathrm{~Hz}, 1 \mathrm{H}, 13-\mathrm{CH}), 4.65$ (apparent t, $J=6.1 \mathrm{~Hz}, 1 \mathrm{H}, 9-\mathrm{CH}), 5.18-5.25(\mathrm{~m}, 1 \mathrm{H}, 18-\mathrm{CH}$ ), $5.25-5.32\left(\mathrm{~m}, 1 \mathrm{H}, 8^{\prime}-\mathrm{CH}\right), 5.39$ (d, $\left.J=17.1 \mathrm{~Hz}, 1 \mathrm{H}, 8^{\prime}-\mathrm{CH}\right), 5.90$ (ddd, $J=17.2,10.2,7.2 \mathrm{~Hz}, 1 \mathrm{H}, 8-\mathrm{CH}$ ); ${ }^{13} \mathrm{C} \mathrm{NMR}\left(\mathrm{CDCl}_{3}, 126 \mathrm{MHz}\right) \delta 12.5\left(21^{\prime}-\mathrm{CH}_{3}\right), 14.4\left(19^{\prime}-\mathrm{CH}_{3}\right), 14.9\left(23^{\prime}-\mathrm{CH}_{3}\right), 21.9\left(17^{\prime}-\mathrm{CH}_{3}\right), 24.1\left(20{ }^{\prime \prime}-\right.$ $\mathrm{CH}_{3}$ or 20 "'- $\left.\mathrm{CH}_{3}\right), 24.1\left(13\right.$ "- $\mathrm{CH}_{3}$ or 13 "'- $\left.\mathrm{CH}_{3}\right), 24.9\left(13 "-\mathrm{CH}_{3}\right.$ or 13"'-- $\left.\mathrm{CH}_{3}\right), 25.0\left(20\right.$ "- $-\mathrm{CH}_{3}$ or 20 "'- $\left.\mathrm{CH}_{3}\right)$, $25.3\left(9^{\prime \prime}-\mathrm{CH}_{3}\right.$ or 9'"- $\left.\mathrm{CH}_{3}\right), 25.4\left(26^{\prime \prime}-\mathrm{CH}_{3}\right.$ or $\left.26^{\prime \prime \prime}-\mathrm{CH}_{3}\right), 26.4\left(26\right.$ "- $\mathrm{CH}_{3}$ or 26 "'- $\left.\mathrm{CH}_{3}\right), 27.7\left(9\right.$ "- $-\mathrm{CH}_{3}$ or 9"'$\left.\mathrm{CH}_{3}\right), 28.1(17-\mathrm{CH}), 32.3(23-\mathrm{CH}), 35.6(21-\mathrm{CH}), 37.1\left(12-\mathrm{CH}_{2}\right.$ or $\left.24-\mathrm{CH}_{2}\right), 37.2\left(12-\mathrm{CH}_{2}\right.$ or $\left.24-\mathrm{CH}_{2}\right)$, $41.3\left(16-\mathrm{CH}_{2}\right), 61.2(25-\mathrm{CH}), 66.6\left(27-\mathrm{CH}_{2}\right), 67.6(15-\mathrm{CH}), 71.6(13-\mathrm{CH}), 72.2(20-\mathrm{CH}), 74.3(22-\mathrm{CH})$, $76.3(10-\mathrm{CH}$ or $11-\mathrm{CH}), 79.0(9-\mathrm{CH}$ or $26-\mathrm{CH}), 79.1(9-\mathrm{CH}$ or $26-\mathrm{CH}), 80.2(10-\mathrm{CH}$ or $11-\mathrm{CH}), 83.8(14-$ $\mathrm{CH}), 99.9$ (13'-C), 100.6 (20'-C), 108.9 (9'-C), 110.1 (26'-C), $118.4\left(8\right.$ '- $\left.\mathrm{CH}_{2}\right), 129.6$ (18-CH), 131.1 (19- 
C), $133.8(8-\mathrm{CH})$; IR $v 2985(\mathrm{~m}), 2930(\mathrm{~m}), 1740(\mathrm{w}), 1455$ (w), 1370 (s), 1220 (s), 1160 (s), 1120 (m), $1055(\mathrm{~m}), 925(\mathrm{~m}), 875(\mathrm{~m}), 695(\mathrm{w}), 515(\mathrm{w}) \mathrm{cm}^{-1}$; HRMS (ESI): m/z [M + H] ${ }^{+}$Calcd. for $\mathrm{C}_{37} \mathrm{H}_{62} \mathrm{ClO}_{9}$ : 685.4077; Found: 685.4081, m/z [M + Na $]^{+}$Calcd. for $\mathrm{C}_{37} \mathrm{H}_{61} \mathrm{ClNaO}_{9}$ : 707.3896; Found: 707.3896.
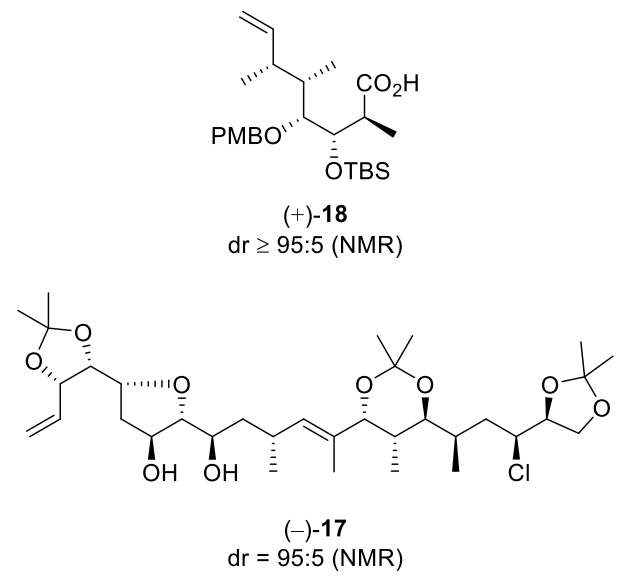

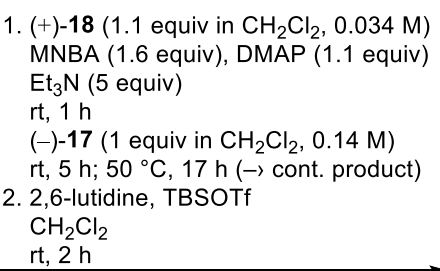

$86 \%(553 \mathrm{mg})$

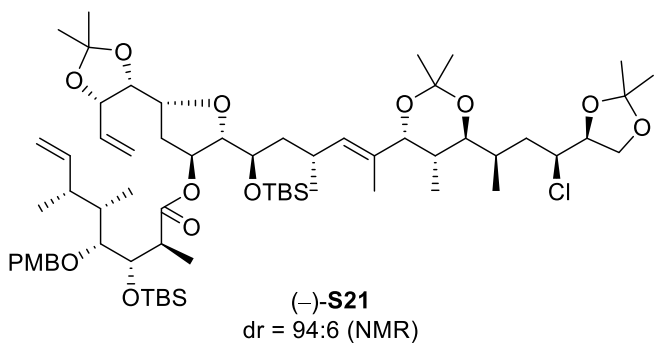

Ester (-)-S21. Note: The reaction was carried out in parallel in two batches. Two sealable glass pressure tubes were charged with the known carboxylic acid (+)-18 ${ }^{16}\left(\mathrm{C}_{25} \mathrm{H}_{42} \mathrm{O}_{5} \mathrm{Si}, 450.69 \mathrm{~g} / \mathrm{mol}, 268 \mathrm{mg}\right.$ [142 $\mathrm{mg}+126 \mathrm{mg}$ ], $595 \mu \mathrm{mol}, 1.1$ equiv) in $\mathrm{CH}_{2} \mathrm{Cl}_{2}(17.45 \mathrm{~mL}$ [9.25 mL+8.2 mL], $0.034 \mathrm{M})$ at ambient temperature to afford two colorless solutions. 2-Methyl-6-nitrobenzoic anhydride (MNBA, $\mathrm{C}_{16} \mathrm{H}_{12} \mathrm{~N}_{2} \mathrm{O}_{7}$, $344.28 \mathrm{~g} / \mathrm{mol}, 298 \mathrm{mg}$ [158 mg+140 mg], $866 \mu \mathrm{mol}, 1.6$ equiv), 4-(dimethylamino)pyridine (DMAP, $\mathrm{C}_{7} \mathrm{H}_{10} \mathrm{~N}_{2}, 122.17 \mathrm{~g} / \mathrm{mol}, 72 \mathrm{mg}$ [38 mg+34 mg], $589 \mu \mathrm{mol}, 1.09$ equiv), and triethylamine (Et $3 \mathrm{~N}, 101.19$ $\mathrm{g} / \mathrm{mol}, 0.726 \mathrm{~g} / \mathrm{mL}, 374 \mu \mathrm{L}$ [198 $\mu \mathrm{L}+176 \mu \mathrm{L}$ ], $272 \mathrm{mg}$ [144 mg+128 mg], $2.69 \mathrm{mmol}, 5$ equiv) were added at ambient temperature to afford two deep yellow reaction mixtures. The two tubes were sealed with Teflon screw caps. After being stirred for $1 \mathrm{~h}$ at ambient temperature, a diastereomeric mixture $(\mathrm{dr}=$ 95:5) of tetrahydrofurane $(-)-\mathbf{1 7}\left(\mathrm{dr}=95: 5 ; \mathrm{C}_{34} \mathrm{H}_{57} \mathrm{ClO}_{9}, 645.27 \mathrm{~g} / \mathrm{mol}, 349 \mathrm{mg}\right.$ [185 mg+164 mg], 541 $\mu$ mol, 1 equiv) dissolved in $\mathrm{CH}_{2} \mathrm{Cl}_{2}(3.8 \mathrm{~mL}[2 \mathrm{~mL}+1.8 \mathrm{~mL}], 0.14 \mathrm{M})$ was added by Pasteur pipettes to both reaction mixtures. The pipettes were rinsed with $\mathrm{CH}_{2} \mathrm{Cl}_{2}(31.1 \mathrm{~mL}$ [16.5 mL+14.6 mL]) (overall: $0.011 \mathrm{M}$ in (-)-17 in $\mathrm{CH}_{2} \mathrm{Cl}_{2}$ ). The two tubes were sealed with Teflon screw caps and stirring of the two yellow reaction mixtures was continued for $5 \mathrm{~h}$ at ambient temperature. The tubes were placed in a preheated oil bath $\left(50{ }^{\circ} \mathrm{C}\right)$. After being stirred for $17 \mathrm{~h}$ at $50{ }^{\circ} \mathrm{C}$, the two resulting yellow reaction mixtures were diluted by the addition of saturated aqueous $\mathrm{NH}_{4} \mathrm{Cl}$ solution at ambient temperature. After being stirred for $1.5 \mathrm{~h}$ at ambient temperature, the resulting two yellow biphasic mixtures were transferred into a single separatory funnel using $\mathrm{CH}_{2} \mathrm{Cl}_{2}$ for rinsing. The phases were separated, and the aqueous layer was extracted with $\mathrm{CH}_{2} \mathrm{Cl}_{2}(4 \times)$. The combined organic layers were dried $\left(\mathrm{MgSO}_{4}\right)$. Removal of all volatiles under reduced pressure and attempted purification of the yellow oil by flash chromatography (cyclohexane-ethyl acetate, 20:1 to 5:1) delivered a colorless viscous oil (546 mg). NMR analysis revealed significant but inseparable impurities, and the colorless viscous oil was used without further purification.

To a solution of the colorless viscous oil $(546 \mathrm{mg})$ in $\mathrm{CH}_{2} \mathrm{Cl}_{2}(70 \mathrm{~mL})$ at ambient temperature was added 2,6-lutidine $\left(\mathrm{C}_{7} \mathrm{H}_{9} \mathrm{~N}, 107.15 \mathrm{~g} / \mathrm{mol}, 0.92 \mathrm{~g} / \mathrm{mL}, 750 \mu \mathrm{L}, 690 \mathrm{mg}, 6.44 \mathrm{mmol}\right)$ and tert-butyldimethylsilyl trifluoromethanesulfonate (TBSOTf, $\mathrm{C}_{7} \mathrm{H}_{15} \mathrm{~F}_{3} \mathrm{O}_{3} \mathrm{SSi}, 264.34 \mathrm{~g} / \mathrm{mol}, 1.151 \mathrm{~g} / \mathrm{mL}, 1.12 \mathrm{~mL}, 1.29 \mathrm{~g}, 4.88$ $\mathrm{mmol}$ ) to afford a colorless solution. After being stirred for $2 \mathrm{~h}$ at ambient temperature, the colorless reaction mixture was diluted by the addition of saturated aqueous $\mathrm{NH}_{4} \mathrm{Cl}$ solution at ambient temperature. The resulting colorless biphasic mixture was transferred into a separatory funnel using $\mathrm{CH}_{2} \mathrm{Cl}_{2}$ for rinsing. The phases were separated, and the aqueous layer was extracted with $\mathrm{CH}_{2} \mathrm{Cl}_{2}(4 \times)$. The combined organic layers were dried $\left(\mathrm{MgSO}_{4}\right)$. Removal of all volatiles under reduced pressure and subsequent purification of the resulting yellow oil by flash chromatography (cyclohexane-ethyl acetate, 100:1 to 10:1) yielded an inseparable mixture of diastereomers of (-)-S21 $\left(\mathrm{C}_{65} \mathrm{H}_{111} \mathrm{ClO}_{13} \mathrm{Si}_{2}, 1192.21 \mathrm{~g} / \mathrm{mol}, 553 \mathrm{mg}, 464 \mu \mathrm{mol}\right.$, $86 \%, \mathrm{dr}=94: 6$ according to NMR evaluation) as a colorless viscous oil. The ratio of diastereomers was determined by integration of the ${ }^{1} \mathrm{H}$ NMR signals at $3.06 \mathrm{ppm}$ (minor) and $3.38 \mathrm{ppm}$ (major). The 
regioselectivity of the esterification was tentatively assigned and later confirmed by the interpretation of a HMBC experiment of $(11 R, 13 S, 14 R, 15 R)$-lytophilippine $\mathrm{A}(-)-\mathbf{1 b} . \mathrm{R}_{\mathrm{f}} 0.66$ (cyclohexane-ethyl acetate, $2: 1) ;[\alpha]_{\mathrm{D}}{ }^{20}=-14.8\left(c=1, \mathrm{CHCl}_{3}\right) ; \mathrm{NMR}$ data are reported for the major diastereomer: ${ }^{1} \mathrm{H} \mathrm{NMR}\left(\mathrm{CDCl}_{3}\right.$, $500 \mathrm{MHz}) \delta-0.01(\mathrm{~s}, 3 \mathrm{H}), 0.03(\mathrm{~s}, 3 \mathrm{H}), 0.04(\mathrm{~s}, 3 \mathrm{H}), 0.08(\mathrm{~s}, 3 \mathrm{H}), 0.67(\mathrm{~d}, J=6.7 \mathrm{~Hz}, 3 \mathrm{H}), 0.87(\mathrm{~s}, 9 \mathrm{H})$, $0.88-0.91(\mathrm{~m}, 12 \mathrm{H}), 0.94(\mathrm{~d}, J=6.8 \mathrm{~Hz}, 3 \mathrm{H}), 0.96-1.00(\mathrm{~m}, 6 \mathrm{H}), 1.21(\mathrm{~d}, J=7.1 \mathrm{~Hz}, 3 \mathrm{H}), 1.27(\mathrm{~s}, 3 \mathrm{H})$, $1.30(\mathrm{~s}, 3 \mathrm{H}), 1.33-1.39(\mathrm{~m}, 7 \mathrm{H}), 1.45(\mathrm{~s}, 3 \mathrm{H}), 1.46(\mathrm{~s}, 3 \mathrm{H}), 1.47-1.56(\mathrm{~m}, 4 \mathrm{H}), 1.63$ (ddd, $J=13.7,9.7$, $4.3 \mathrm{~Hz}, 1 \mathrm{H}$ ), 1.71 (apparent quind, $J=6.7,4.1 \mathrm{~Hz}, 1 \mathrm{H}), 1.87$ (ddd, $J=13.8,9.6,2.5 \mathrm{~Hz}, 1 \mathrm{H}), 1.90-2.03$ (m, 4H), 2.28 (apparent dq, $J=13.9,6.8 \mathrm{~Hz}, 1 \mathrm{H}), 2.32-2.41(\mathrm{~m}, 1 \mathrm{H}), 2.73$ (apparent qd, $J=7.1,4.7 \mathrm{~Hz}$, $1 \mathrm{H}), 3.24$ (dd, $J=7.8,1.4 \mathrm{~Hz}, 1 \mathrm{H}), 3.38$ (apparent t, $J=4.2 \mathrm{~Hz}, 1 \mathrm{H}), 3.59-3.64(\mathrm{~m}, 1 \mathrm{H}), 3.78-3.83(\mathrm{~m}$, 4H), 3.85 (apparent t, $J=1.9 \mathrm{~Hz}, 1 \mathrm{H}), 3.87-3.92(\mathrm{~m}, 1 \mathrm{H}), 3.94(\mathrm{ddd}, J=11.3,5.7,2.6 \mathrm{~Hz}, 1 \mathrm{H}), 4.03$ (dd, $J=7.9,6.5 \mathrm{~Hz}, 1 \mathrm{H}), 4.06-4.11(\mathrm{~m}, 2 \mathrm{H}), 4.23$ (apparent q, $J=6.3 \mathrm{~Hz}, 1 \mathrm{H}), 4.27$ (apparent t, $J=4.5 \mathrm{~Hz}$, $1 \mathrm{H}), 4.43(\mathrm{~d}, J=10.8 \mathrm{~Hz}, 1 \mathrm{H}), 4.60-4.67(\mathrm{~m}, 2 \mathrm{H}), 4.96(\mathrm{~d}, J=17.2 \mathrm{~Hz}, 1 \mathrm{H}), 4.99(\mathrm{~d}, J=10.3 \mathrm{~Hz}, 1 \mathrm{H})$, 5.20 (apparent t, $J=10.6 \mathrm{~Hz}, 2 \mathrm{H}), 5.25(\mathrm{~d}, J=5.4 \mathrm{~Hz}, 1 \mathrm{H}), 5.31-5.41(\mathrm{~m}, 1 \mathrm{H}), 5.72(\mathrm{ddd}, J=17.7,10.4$, $7.8 \mathrm{~Hz}, 1 \mathrm{H}), 5.92(\mathrm{ddd}, J=17.0,10.5,6.3 \mathrm{~Hz}, 1 \mathrm{H}), 6.86(\mathrm{~d}, J=8.6 \mathrm{~Hz}, 2 \mathrm{H}), 7.23-7.27(\mathrm{~m}, 2 \mathrm{H}) ;{ }^{13} \mathrm{C} \mathrm{NMR}$ $\left(\mathrm{CDCl}_{3}, 126 \mathrm{MHz}\right) \delta-4.3\left(\mathrm{CH}_{3}\right),-4.2\left(\mathrm{CH}_{3}\right),-4.1\left(\mathrm{CH}_{3}\right),-3.9\left(\mathrm{CH}_{3}\right), 11.6\left(\mathrm{CH}_{3}\right), 12.6\left(\mathrm{CH}_{3}\right), 12.7\left(\mathrm{CH}_{3}\right)$, $14.3\left(\mathrm{CH}_{3}\right), 14.9\left(\mathrm{CH}_{3}\right), 16.9\left(\mathrm{CH}_{3}\right), 18.1(\mathrm{C}), 18.4(\mathrm{C}), 21.8\left(\mathrm{CH}_{3}\right), 24.1\left(\mathrm{CH}_{3}\right), 25.1\left(\mathrm{CH}_{3}\right), 25.4\left(\mathrm{CH}_{3}\right)$, $25.5\left(\mathrm{CH}_{3}\right), 26.1\left(\mathrm{CH}_{3}\right), 26.2\left(\mathrm{CH}_{3}\right), 26.4\left(\mathrm{CH}_{3}\right), 27.8\left(\mathrm{CH}_{3}\right), 28.9(\mathrm{CH}), 32.3(\mathrm{CH}), 35.8(\mathrm{CH}), 37.1$ $\left(\mathrm{CH}_{2}\right), 38.1\left(\mathrm{CH}_{2}\right), 39.1(\mathrm{CH}), 40.9(\mathrm{CH}), 42.0(\mathrm{CH}), 42.6\left(\mathrm{CH}_{2}\right), 55.4\left(\mathrm{CH}_{3}\right), 61.2(\mathrm{CH}), 66.7\left(\mathrm{CH}_{2}\right), 70.9$ $(\mathrm{CH}), 72.1(\mathrm{CH}), 73.4(\mathrm{CH}), 73.5\left(\mathrm{CH}_{2}\right), 74.3(\mathrm{CH}), 75.1(\mathrm{CH}), 76.5(\mathrm{CH}), 78.9(\mathrm{CH}), 79.1(\mathrm{CH}), 80.3$ $(\mathrm{CH}), 83.4(\mathrm{CH}), 86.9(\mathrm{CH}), 100.5(\mathrm{C}), 108.8(\mathrm{C}), 110.1(\mathrm{C}), 113.7(\mathrm{CH}), 114.1\left(\mathrm{CH}_{2}\right), 117.3\left(\mathrm{CH}_{2}\right)$, $129.1(\mathrm{CH}), 130.2(\mathrm{CH}), 131.0(\mathrm{C}), 131.3(\mathrm{C}), 134.2(\mathrm{CH}), 144.2(\mathrm{CH}), 159.1(\mathrm{C}), 175.0(\mathrm{C}) ; \mathrm{IR} \vee 2930$ (m), 1730 (w), 1615 (w), 1515 (w), 1460 (w), 1380 (m), 1250 (s), 1220 (s), 1170 (m), 1060 (s), 915 (m), 835 (s), 775 (s), $670(\mathrm{w}), 510(\mathrm{w}) \mathrm{cm}^{-1}$; HRMS (ESI): m/z $[\mathrm{M}+\mathrm{H}]^{+}$Calcd. for $\mathrm{C}_{65} \mathrm{H}_{112} \mathrm{ClO}_{13} \mathrm{Si}_{2}$ : 1191.73245; Found: 1191.73508, $\mathrm{m} / \mathrm{z}\left[\mathrm{M}+\mathrm{NH}_{4}\right]^{+}$Calcd. for $\mathrm{C}_{65} \mathrm{H}_{115} \mathrm{ClNO}_{13} \mathrm{Si}_{2}$ : 1208.75900 ; Found: 1208.76067, $\mathrm{m} / \mathrm{z}[\mathrm{M}+\mathrm{Na}]^{+}$Calcd. for $\mathrm{C}_{65} \mathrm{H}_{111} \mathrm{ClNaO}_{13} \mathrm{Si}_{2}$ : 1213.71440; Found: 1213.71564 .

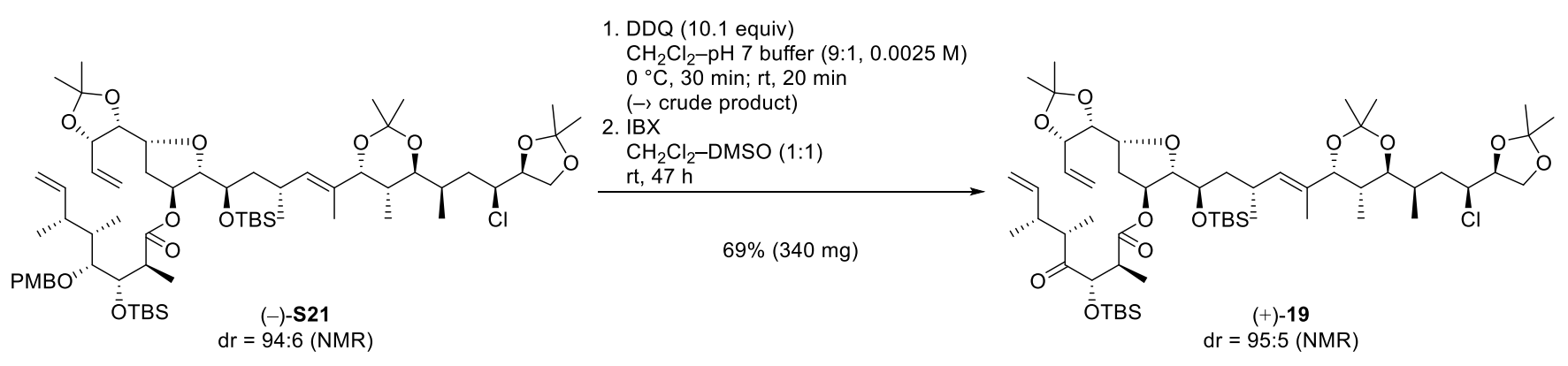

Ketone (+)-19. To a stirred colorless biphasic mixture of a diastereomeric mixture $(\mathrm{dr}=94: 6)$ of the ester (-)-S21 ( $\mathrm{C}_{65} \mathrm{H}_{111} \mathrm{ClO}_{13} \mathrm{Si}_{2}, 1192.21 \mathrm{~g} / \mathrm{mol}, 548 \mathrm{mg}, 460 \mu \mathrm{mol}, 1$ equiv) in $\mathrm{CH}_{2} \mathrm{Cl}_{2}(165.6 \mathrm{~mL}, 0.0028 \mathrm{M})$ and aqueous phosphate buffer $\left(\mathrm{pH} 7,18.4 \mathrm{~mL}\right.$ ) (overall: $0.0025 \mathrm{M}$ ) at $0{ }^{\circ} \mathrm{C}$ was added 2,3-dichloro-5,6dicyano- $p$-benzoquinone (DDQ, $\mathrm{C}_{8} \mathrm{Cl}_{2} \mathrm{~N}_{2} \mathrm{O}_{2}, 227 \mathrm{~g} / \mathrm{mol}, 1.05 \mathrm{~g}, 4.63 \mathrm{mmol}, 10.1$ equiv) to afford a dark red biphasic mixture. After being stirred for $30 \mathrm{~min}$ at $0{ }^{\circ} \mathrm{C}$ and for $20 \mathrm{~min}$ at ambient temperature, the dark red biphasic mixture was diluted by the addition of saturated aqueous $\mathrm{NaHCO}_{3}$ solution at $0{ }^{\circ} \mathrm{C}$. The resulting red biphasic mixture was transferred into a separatory funnel using $\mathrm{CH}_{2} \mathrm{Cl}_{2}$ for rinsing. The phases were separated, and the aqueous layer was extracted with diethyl ether $(4 \times)$. The combined organic layers were dried $\left(\mathrm{MgSO}_{4}\right)$. Removal of volatiles under reduced pressure $\left(25^{\circ} \mathrm{C}, 450\right.$ mbar) delivered a red oil. Purification of the red oil by flash chromatography ( $n$-pentane-diethyl ether, 20:1 to 5:1) and subsequent removal of all volatiles under reduced pressure $\left(25^{\circ} \mathrm{C}, 450 \mathrm{mbar}\right)$ delivered a colorless oil that was used immediately in the next reaction to avoid degradation (probably by intramolecular transesterification).

To a solution of the colorless oil in $\mathrm{CH}_{2} \mathrm{Cl}_{2}(92 \mathrm{~mL})$ and DMSO $(92 \mathrm{~mL})$ at $0{ }^{\circ} \mathrm{C}$ was added 2iodoxybenzoic acid (IBX, $\mathrm{C}_{7} \mathrm{H}_{5} \mathrm{IO}_{4}, 280.02 \mathrm{~g} / \mathrm{mol}, 3.22 \mathrm{~g}, 11.5 \mathrm{mmol}$ ) to afford a white suspension. After being stirred for $5 \mathrm{~min}$ at $0{ }^{\circ} \mathrm{C}$ and for $24 \mathrm{~h}$ at ambient temperature, additional $\mathrm{IBX}\left(\mathrm{C}_{7} \mathrm{H}_{5} \mathrm{IO}_{4}, 280.02\right.$ $\mathrm{g} / \mathrm{mol}, 3.22 \mathrm{~g}, 11.5 \mathrm{mmol}$ ) was added to the resulting clear colorless reaction mixture at $0{ }^{\circ} \mathrm{C}$ to afford a 
white suspension. After being stirred for $23 \mathrm{~h}$ at ambient temperature, the resulting clear colorless reaction mixture was diluted by the addition of saturated aqueous $\mathrm{Na}_{2} \mathrm{~S}_{2} \mathrm{O}_{3}$ solution at $0{ }^{\circ} \mathrm{C}$ and stirring was continued for $30 \mathrm{~min}$ at $0{ }^{\circ} \mathrm{C}$. The resulting clear colorless biphasic mixture was transferred into a separatory funnel using $\mathrm{CH}_{2} \mathrm{Cl}_{2}$ for rinsing. The phases were separated, and the aqueous layer was extracted with $\mathrm{CH}_{2} \mathrm{Cl}_{2}(4 \times)$. The combined organic layers were transferred into a separatory funnel and washed with saturated aqueous $\mathrm{NaCl}$ solution $(2 \times)$. The combined organic layers were dried $\left(\mathrm{MgSO}_{4}\right)$. Removal of all volatiles under reduced pressure and subsequent purification of the colorless oil by flash chromatography (cyclohexane-ethyl acetate, 100:1 to 50:1) delivered an inseparable mixture of diastereomers of (+)-19 $\left(\mathrm{C}_{57} \mathrm{H}_{101} \mathrm{ClO}_{12} \mathrm{Si}_{2}, 1070.04 \mathrm{~g} / \mathrm{mol}, 340 \mathrm{mg}, 318 \mu \mathrm{mol}, 69 \%, \mathrm{dr}=95: 5\right.$ according to NMR evaluation) as a colorless oil. The ratio of diastereomers was determined by integration of the ${ }^{1} \mathrm{H}$ NMR signals at $3.06 \mathrm{ppm}$ (minor) and $3.24 \mathrm{ppm}$ (major). $\mathrm{R}_{\mathrm{f}} 0.54$ (cyclohexane-ethyl acetate, $5: 1$ ); $[\alpha]_{\mathrm{D}}{ }^{20}$ $=+12.8\left(c=1, \mathrm{CHCl}_{3}\right)$; $\mathrm{NMR}$ data are reported for the major diastereomer: ${ }^{1} \mathrm{H} \mathrm{NMR}\left(\mathrm{CDCl}_{3}, 500 \mathrm{MHz}\right) \delta$ $-0.00(\mathrm{~s}, 3 \mathrm{H}), 0.03(\mathrm{~s}, 3 \mathrm{H}), 0.04(\mathrm{~s}, 3 \mathrm{H}), 0.09(\mathrm{~s}, 3 \mathrm{H}), 0.68(\mathrm{~d}, J=6.7 \mathrm{~Hz}, 3 \mathrm{H}), 0.87(\mathrm{~s}, 9 \mathrm{H}), 0.89-0.94(\mathrm{~m}$, $12 \mathrm{H}), 0.95-1.00(\mathrm{~m}, 9 \mathrm{H}), 1.08(\mathrm{~d}, J=7.1 \mathrm{~Hz}, 3 \mathrm{H}), 1.27(\mathrm{~s}, 3 \mathrm{H}), 1.30(\mathrm{~s}, 3 \mathrm{H}), 1.34-1.39$ (m, 7H), $1.44-$ $1.47(\mathrm{~m}, 6 \mathrm{H}), 1.51-1.61(\mathrm{~m}, 4 \mathrm{H}), 1.66(\mathrm{ddd}, J=13.6,9.6,4.2 \mathrm{~Hz}, 1 \mathrm{H}), 1.87(\mathrm{ddd}, J=14.1,9.7,2.5 \mathrm{~Hz}$, 1H), 1.91-2.05 (m, 4H), 2.37-2.46 (m, 1H), 2.51 (apparent sxt, $J=6.8 \mathrm{~Hz}, 1 \mathrm{H}), 2.84-2.95(\mathrm{~m}, 2 \mathrm{H}), 3.24$ $(\mathrm{dd}, J=8.0,1.4 \mathrm{~Hz}, 1 \mathrm{H}), 3.63$ (apparent dt, $J=9.2,3.4 \mathrm{~Hz}, 1 \mathrm{H}), 3.80(\mathrm{dd}, J=8.4,6.5 \mathrm{~Hz}, 1 \mathrm{H}), 3.88$ (apparent t, $J=1.9 \mathrm{~Hz}, 1 \mathrm{H}), 3.89-3.97(\mathrm{~m}, 2 \mathrm{H}), 4.04(\mathrm{dd}, J=7.9,6.4 \mathrm{~Hz}, 1 \mathrm{H}), 4.06-4.12(\mathrm{~m}, 2 \mathrm{H}), 4.23$ (apparent q, $J=6.2 \mathrm{~Hz}, 1 \mathrm{H}), 4.59-4.66(\mathrm{~m}, 2 \mathrm{H}), 4.97-5.03(\mathrm{~m}, 2 \mathrm{H}), 5.19-5.25(\mathrm{~m}, 2 \mathrm{H}), 5.27-5.31(\mathrm{~m}$, $1 \mathrm{H}), 5.37(\mathrm{~d}, J=17.1 \mathrm{~Hz}, 1 \mathrm{H}), 5.73(\mathrm{ddd}, J=17.3,10.2,7.3 \mathrm{~Hz}, 1 \mathrm{H}), 5.94(\mathrm{ddd}, J=17.0,10.6,6.2 \mathrm{~Hz}$, $1 \mathrm{H}) ;{ }^{13} \mathrm{C} \mathrm{NMR}\left(\mathrm{CDCl}_{3}, 126 \mathrm{MHz}\right) \delta-4.6\left(\mathrm{CH}_{3}\right),-4.3\left(\mathrm{CH}_{3}\right),-4.2\left(\mathrm{CH}_{3}\right),-4.2\left(\mathrm{CH}_{3}\right), 11.4\left(\mathrm{CH}_{3}\right), 12.6$ $\left(\mathrm{CH}_{3}\right), 12.7\left(\mathrm{CH}_{3}\right), 14.2\left(\mathrm{CH}_{3}\right), 14.9\left(\mathrm{CH}_{3}\right), 15.6\left(\mathrm{CH}_{3}\right), 18.1(\mathrm{C}), 18.4(\mathrm{C}), 21.8\left(\mathrm{CH}_{3}\right), 24.1\left(\mathrm{CH}_{3}\right), 25.1$ $\left(\mathrm{CH}_{3}\right), 25.4\left(\mathrm{CH}_{3}\right), 25.5\left(\mathrm{CH}_{3}\right), 26.0\left(\mathrm{CH}_{3}\right), 26.1\left(\mathrm{CH}_{3}\right), 26.4\left(\mathrm{CH}_{3}\right), 27.8\left(\mathrm{CH}_{3}\right), 28.8(\mathrm{CH}), 32.3(\mathrm{CH})$, $35.8(\mathrm{CH}), 37.1\left(\mathrm{CH}_{2}\right), 38.0\left(\mathrm{CH}_{2}\right), 39.5(\mathrm{CH}), 42.6\left(\mathrm{CH}_{2}\right), 42.9(\mathrm{CH}), 45.1\left(\mathrm{CH}_{2}\right), 61.2(\mathrm{CH}), 66.7\left(\mathrm{CH}_{2}\right)$, $70.9(\mathrm{CH}), 72.1(\mathrm{CH}), 74.3(\mathrm{CH}), 75.5(\mathrm{CH}), 76.5(\mathrm{CH}), 78.9(\mathrm{CH}), 79.0(\mathrm{CH}), 79.1(\mathrm{CH}), 80.3(\mathrm{CH})$, $86.9(\mathrm{CH}), 100.5(\mathrm{C}), 108.8(\mathrm{C}), 110.1(\mathrm{C}), 114.9\left(\mathrm{CH}_{2}\right), 117.4\left(\mathrm{CH}_{2}\right), 130.3(\mathrm{CH}), 131.0(\mathrm{C}), 134.1(\mathrm{CH})$, $141.8(\mathrm{CH}), 173.2(\mathrm{C}), 213.3(\mathrm{C})$; IR $\vee 2930(\mathrm{w}), 1730(\mathrm{w}), 1460(\mathrm{w}), 1380(\mathrm{~m}), 1250(\mathrm{~m}), 1220(\mathrm{~s}), 1170$ (m), 1065 (s), 920 (m), 835 (s), 775 (s), 735 (w), $675(\mathrm{w}), 510(\mathrm{w}) \mathrm{cm}^{-1}$; HRMS (ESI): m/z [M + H] Calcd. for $\mathrm{C}_{57} \mathrm{H}_{102} \mathrm{ClO}_{12} \mathrm{Si}_{2}$ : 1069.65929; Found: 1069.66103, $\mathrm{m} / \mathrm{z}\left[\mathrm{M}+\mathrm{Na}^{+}\right.$Calcd. for $\mathrm{C}_{57} \mathrm{H}_{101} \mathrm{ClNaO}_{12} \mathrm{Si}_{2}$ : 1091.64123; Found: 1091.64213.

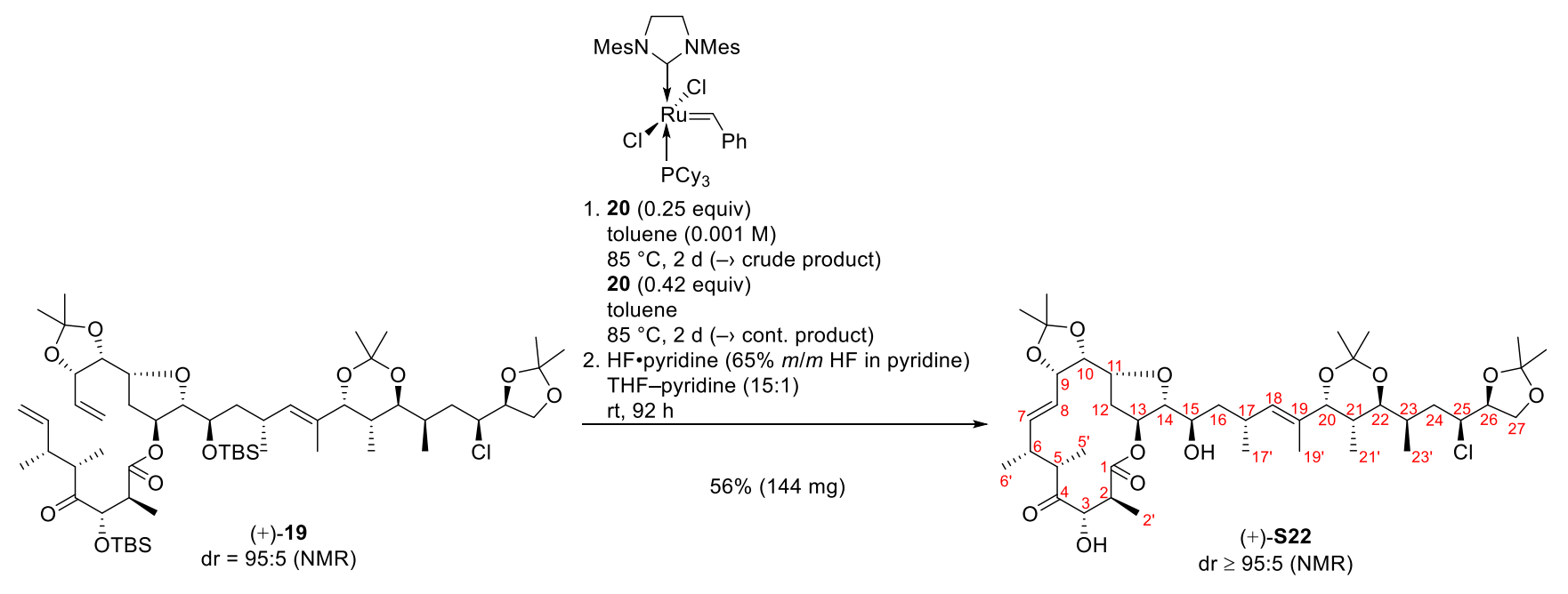

[14]Macrolactone (+)-S22. Note: The reaction was carried out in parallel in two batches and required two cycles for complete consumption of the starting material. Procedure is unoptimized. Conversion was not traceable by TLC. Two sealable glass pressure tubes were charged with a diastereomeric mixture $(\mathrm{dr}=$ 95:5) of ketone (+)-19 $\left(\mathrm{C}_{57} \mathrm{H}_{101} \mathrm{ClO}_{12} \mathrm{Si}_{2}, 1070.04 \mathrm{~g} / \mathrm{mol}, 340 \mathrm{mg}\right.$ [2×170 mg], $318 \mu \mathrm{mol}, 1$ equiv) in toluene $(318 \mathrm{~mL}$ [2×159 mL], $0.001 \mathrm{M}$, degassed by three freeze-pump-thaw cycles) to afford two colorless solutions. Second generation Grubbs catalyst $20\left(\mathrm{C}_{46} \mathrm{H}_{65} \mathrm{Cl}_{2} \mathrm{~N}_{2} \mathrm{PRu}, 848.97 \mathrm{~g} / \mathrm{mol}, 27.2 \mathrm{mg}\right.$ [ $2 \times 13.6 \mathrm{mg}$ ], $32 \mu \mathrm{mol}, 0.1$ equiv) was added at ambient temperature to both solutions to afford two pink 
solutions. The two tubes were sealed with Teflon screw caps and placed in a pre-heated oil bath $\left(85^{\circ} \mathrm{C}\right)$. After being stirred for $15 \mathrm{~h}$ at $85{ }^{\circ} \mathrm{C}$, the resulting two brown reaction mixtures were cooled to ambient temperature using a water bath. Additional metathesis pre-catalyst $20\left(\mathrm{C}_{46} \mathrm{H}_{65} \mathrm{Cl}_{2} \mathrm{~N}_{2} \mathrm{PRu}, 848.97 \mathrm{~g} / \mathrm{mol}\right.$, $13.6 \mathrm{mg}$ [ $2 \times 6.8 \mathrm{mg}$ ], $16 \mu \mathrm{mol}, 0.05$ equiv) was then added to both reaction mixtures, and the brown reaction mixtures were placed in a pre-heated oil bath $\left(85^{\circ} \mathrm{C}\right)$. After being stirred for $9 \mathrm{~h}$ at $85{ }^{\circ} \mathrm{C}$, the resulting two brown reaction mixtures were cooled in a water bath to ambient temperature. Additional 20 $\left(\mathrm{C}_{46} \mathrm{H}_{65} \mathrm{Cl}_{2} \mathrm{~N}_{2} \mathrm{PRu}, 848.97 \mathrm{~g} / \mathrm{mol}, 13.6 \mathrm{mg}\right.$ [2×6.8 mg], $16 \mu \mathrm{mol}, 0.05$ equiv $)$ was then added to both reaction mixtures, and the two brown reaction mixtures were placed in a pre-heated oil bath $\left(85^{\circ} \mathrm{C}\right)$. After being stirred for $15 \mathrm{~h}$ at $85{ }^{\circ} \mathrm{C}$, the resulting two brown reaction mixtures were cooled to ambient temperature in using a water bath. Additional $20\left(\mathrm{C}_{46} \mathrm{H}_{65} \mathrm{Cl}_{2} \mathrm{~N}_{2} \mathrm{PRu}, 848.97 \mathrm{~g} / \mathrm{mol}, 13.6 \mathrm{mg}\right.$ [2×6.8 mg], 16 $\mu$ mol, 0.05 equiv) was then added to both reaction mixtures, and the two brown reaction mixtures were placed in a pre-heated oil bath $\left(85^{\circ} \mathrm{C}\right)$. After being stirred for $9 \mathrm{~h}$ at $85^{\circ} \mathrm{C}$, the resulting two dark brown solutions were cooled to ambient temperature and transferred into a single round-bottomed flask using $\mathrm{CH}_{2} \mathrm{Cl}_{2}$ for rinsing. Removal of all volatiles under reduced pressure and attempted purification of the black oil by flash chromatography (cyclohexane-ethyl acetate, 100:1 to 10:1) delivered a viscos colorless oil $(280 \mathrm{mg}) .{ }^{1} \mathrm{H}$ NMR examination of the oil indicated $50 \%$ conversion. In order to allow for complete conversion, the oil was subjected to a second RCM procedure:

Two sealable glass pressure tubes were charged with the viscos colorless oil $(280 \mathrm{mg}$ [2×140 $\mathrm{mg}])$ in toluene $(262 \mathrm{~mL}[2 \times 131 \mathrm{~mL}]$, degassed by three freeze-pump-thaw cycles) to afford two colorless solutions. Metathesis pre-catalyst $20\left(\mathrm{C}_{46} \mathrm{H}_{65} \mathrm{Cl}_{2} \mathrm{~N}_{2} \mathrm{PRu}, 848.97 \mathrm{~g} / \mathrm{mol}, 56 \mathrm{mg}\right.$ [2×28 mg], $66 \mu \mathrm{mol}, 0.21$ equiv based on substrate of first cycle) was added at ambient temperature to both solutions to afford two pink solutions. The two tubes were sealed with Teflon screw caps and placed in a pre-heated oil bath (85 ${ }^{\circ} \mathrm{C}$ ). After being stirred for $24 \mathrm{~h}$ at $85{ }^{\circ} \mathrm{C}$, the two brown reaction mixtures were cooled to ambient temperature using a water bath. Additional $20\left(\mathrm{C}_{46} \mathrm{H}_{65} \mathrm{Cl}_{2} \mathrm{~N}_{2} \mathrm{PRu}, 848.97 \mathrm{~g} / \mathrm{mol}, 56 \mathrm{mg}\right.$ [2×28 mg], 66 $\mu$ mol, 0.21 equiv based on substrate of first cycle) was added to both reaction mixtures, and the two brown reaction mixtures were placed in a pre-heated oil bath $\left(85^{\circ} \mathrm{C}\right)$. After being stirred for $24 \mathrm{~h}$ at $85^{\circ} \mathrm{C}$, the resulting two dark brown solutions were cooled to ambient temperature and transferred into a single round-bottomed flask using $\mathrm{CH}_{2} \mathrm{Cl}_{2}$ for rinsing. Removal of all volatiles under reduced pressure and attempted purification of the black oil by flash chromatography (cyclohexane-ethyl acetate, 100:1 to 10:1) delivered a viscos colorless oil $(253 \mathrm{mg}) .{ }^{1} \mathrm{H}$ NMR examination indicted complete consumption but contamination with impurities of unknown constitution. The viscos colorless oil was used without further purification.

A sealable polypropylene reaction vessel was charged with a colorless solution of the viscos colorless oil $(253 \mathrm{mg})$ in THF $(24 \mathrm{~mL})$ and pyridine $(1.6 \mathrm{~mL})$ at ambient temperature. Hydrogen fluoride pyridine complex (HF-pyridine, $\mathrm{C}_{5} \mathrm{H}_{6} \mathrm{FN}, 65 \% \mathrm{~m} / \mathrm{m} \mathrm{HF}$ in pyridine, $1.1 \mathrm{~g} / \mathrm{mL}, 813 \mu \mathrm{L}, 894 \mathrm{mg}$ containing $581 \mathrm{mg}$ $\mathrm{HF}, 20.01 \mathrm{~g} / \mathrm{mol}, 29.04 \mathrm{mmol}$ ) was added at ambient temperature to afford a yellow solution and the reaction vessel was sealed with a polypropylene screw cap. After being stirred for $24 \mathrm{~h}$ at ambient temperature, additional $\mathrm{HF} \cdot$ pyridine $\left(\mathrm{C}_{5} \mathrm{H}_{6} \mathrm{FN}, 65 \% \mathrm{~m} / \mathrm{m} \mathrm{HF}\right.$ in pyridine, $1.1 \mathrm{~g} / \mathrm{mL}, 813 \mu \mathrm{L}, 894 \mathrm{mg}$ containing $581 \mathrm{mg} \mathrm{HF}, 20.01 \mathrm{~g} / \mathrm{mol}, 29.04 \mathrm{mmol}$ ) was added. After being stirred for $24 \mathrm{~h}$ at ambient temperature, additional $\mathrm{HF} \cdot$ pyridine $\left(\mathrm{C}_{5} \mathrm{H}_{6} \mathrm{FN}, 65 \% \mathrm{~m} / \mathrm{m} \mathrm{HF}\right.$ in pyridine, $1.1 \mathrm{~g} / \mathrm{mL}, 813 \mu \mathrm{L}, 894 \mathrm{mg}$ containing $581 \mathrm{mg} \mathrm{HF}, 20.01 \mathrm{~g} / \mathrm{mol}, 29.04 \mathrm{mmol}$ ) was added. After being stirred for $44 \mathrm{~h}$ at ambient temperature, the resulting yellow reaction mixture was diluted by the very slow addition of saturated aqueous $\mathrm{K}_{2} \mathrm{CO}_{3}$ solution at $0{ }^{\circ} \mathrm{C}$. The resulting clear colorless biphasic mixture was transferred into a separatory funnel using ethyl acetate for rinsing. The phases were separated, and the aqueous layer was extracted with ethyl acetate $(4 \times)$. The combined organic layers were dried $\left(\mathrm{MgSO}_{4}\right)$. Removal of all volatiles under reduced pressure and subsequent purification of the colorless oil by flash chromatography (cyclohexane-ethyl acetate, 20:1 to 2:1) delivered (+)-S22 $\left(\mathrm{C}_{43} \mathrm{H}_{69} \mathrm{ClO}_{12}, 813.46 \mathrm{~g} / \mathrm{mol}, 144 \mathrm{mg}, 177\right.$ $\mu \mathrm{mol}, 56 \%, \mathrm{dr} \geq 95: 5$ according to NMR evaluation) as a white solid. The configuration of the 7-CH/8$\mathrm{CH}$ double bond was tentatively assigned according to the expected outcome of the RCM and later confirmed by coupling constant analysis of $(11 R, 13 S, 14 R, 15 R)$-lytophilippine $\mathrm{A}(-)-\mathbf{1 b} . \quad \mathrm{R}_{\mathrm{f}} 0.34$ (cyclohexane-ethyl acetate, 1:1); m.p. $59.5{ }^{\circ} \mathrm{C} ;[\alpha]_{\mathrm{D}}{ }^{25}=+41.2\left(c=1, \mathrm{CHCl}_{3}\right) ;{ }^{1} \mathrm{H}$ NMR $\left(\mathrm{CDCl}_{3}, 700\right.$ MHz) $\delta 0.66\left(\mathrm{~d}, J=6.7 \mathrm{~Hz}, 3 \mathrm{H}, 21^{\prime}-\mathrm{CH}_{3}\right), 0.96\left(\mathrm{~d}, J=6.6 \mathrm{~Hz}, 3 \mathrm{H}, 17^{\prime}-\mathrm{CH}_{3}\right), 0.98(\mathrm{~d}, J=6.9 \mathrm{~Hz}, 3 \mathrm{H}, 23 '-$ 
$\left.\mathrm{CH}_{3}\right), 1.02\left(\mathrm{~d}, J=6.9 \mathrm{~Hz}, 3 \mathrm{H}, 6^{\prime}-\mathrm{CH}_{3}\right), 1.16\left(\mathrm{~d}, J=7.2 \mathrm{~Hz}, 3 \mathrm{H}, 5^{\prime}-\mathrm{CH}_{3}\right), 1.27\left(\mathrm{~s}, 3 \mathrm{H}\right.$, acetonide- $\left.\mathrm{CH}_{3}\right), 1.30$ $\left(\mathrm{s}, 3 \mathrm{H}\right.$, acetonide- $\left.\mathrm{CH}_{3}\right), 1.32\left(\mathrm{~d}, J=7.2 \mathrm{~Hz}, 3 \mathrm{H}, 2^{\prime}-\mathrm{CH}_{3}\right), 1.36-1.38\left(\mathrm{~m}, 6 \mathrm{H}, 2\right.$ a acetonide- $\left.\mathrm{CH}_{3}\right), 1.45(\mathrm{~s}$, $3 \mathrm{H}$, acetonide- $\left.\mathrm{CH}_{3}\right), 1.46-1.51\left(\mathrm{~m}, 5 \mathrm{H}, 16-\mathrm{CH}_{2}+\right.$ acetonide $\left.-\mathrm{CH}_{3}\right), 1.52-1.57\left(\mathrm{~m}, 4 \mathrm{H}, 24-\mathrm{CH}_{2}+19 '-\mathrm{CH}_{3}\right)$, $1.75\left(\mathrm{dd}, J=13.9,4.0 \mathrm{~Hz}, 1 \mathrm{H}, 12-\mathrm{CH}_{2}\right), 1.87$ (ddd, $\left.J=14.1,9.6,2.6 \mathrm{~Hz}, 1 \mathrm{H}, 24-\mathrm{CH}_{2}\right), 1.91-1.99(\mathrm{~m}, 3 \mathrm{H}$, 12- $\mathrm{CH}_{2}+21-\mathrm{CH}+23-\mathrm{CH}$ ), 2.45 (apparent sxt, $J=7.3 \mathrm{~Hz}, 1 \mathrm{H}, 6-\mathrm{CH}$ ), 2.49 (br. s, 1H, -OH), 2.60 (apparent dsxt, $J=9.3,6.9 \mathrm{~Hz}, 1 \mathrm{H}, 17-\mathrm{CH}$ ), 2.69 (apparent qd, $J=7.0,5.4 \mathrm{~Hz}, 1 \mathrm{H}, 2-\mathrm{CH}$ ), 2.83 (apparent quin, $J=$ $7.4 \mathrm{~Hz}, 1 \mathrm{H}, 5-\mathrm{CH}), 3.23(\mathrm{dd}, J=7.8,1.7 \mathrm{~Hz}, 1 \mathrm{H}, 22-\mathrm{CH}), 3.75$ (apparent dt, $J=8.1,4.1 \mathrm{~Hz}, 1 \mathrm{H}, 15-\mathrm{CH}$ ), 3.80 (dd, $\left.J=8.5,6.5 \mathrm{~Hz}, 1 \mathrm{H}, 27-\mathrm{CH}_{2}\right), 3.83$ (apparent dt, $\left.J=11.5,3.5 \mathrm{~Hz}, 1 \mathrm{H}, 11-\mathrm{CH}\right), 3.93-3.98(\mathrm{~m}$, $2 \mathrm{H}, 25-\mathrm{CH}+-\mathrm{OH}), 4.00(\mathrm{~d}, J=3.2 \mathrm{~Hz}, 1 \mathrm{H}, 14-\mathrm{CH}), 4.05-4.08\left(\mathrm{~m}, 2 \mathrm{H}, 20-\mathrm{CH}+27-\mathrm{CH}_{2}\right), 4.13(\mathrm{dd}, J=$ $10.2,5.1 \mathrm{~Hz}, 1 \mathrm{H}, 3-\mathrm{CH}), 4.22$ (apparent q, $J=6.3 \mathrm{~Hz}, 1 \mathrm{H}, 26-\mathrm{CH}), 4.48$ (dd, $J=7.4,3.1 \mathrm{~Hz}, 1 \mathrm{H}, 10-\mathrm{CH}$ ), $4.79(\mathrm{dd}, J=7.4,2.1 \mathrm{~Hz}, 1 \mathrm{H}, 9-\mathrm{CH}), 5.17(\mathrm{~d}, J=4.5 \mathrm{~Hz}, 1 \mathrm{H}, 13-\mathrm{CH}), 5.30(\mathrm{~d}, J=9.8 \mathrm{~Hz}, 1 \mathrm{H}, 18-\mathrm{CH})$, 5.51-5.58 (m, 2H, 7-CH+8-CH); ${ }^{13} \mathrm{C} \mathrm{NMR}\left(\mathrm{CDCl}_{3}, 176 \mathrm{MHz}\right) \delta 12.6\left(21^{\prime}-\mathrm{CH}_{3}\right), 13.9\left(2^{\prime}-\mathrm{CH}_{3}\right), 14.3\left(5^{\prime}-\right.$ $\mathrm{CH}_{3}$ or $\left.19^{\prime}-\mathrm{CH}_{3}\right), 14.3\left(5^{\prime}-\mathrm{CH}_{3}\right.$ or $\left.19^{\prime}-\mathrm{CH}_{3}\right), 14.9\left(23^{\prime}-\mathrm{CH}_{3}\right), 18.0\left(6^{\prime}-\mathrm{CH}_{3}\right), 20.9\left(17^{\prime}-\mathrm{CH}_{3}\right), 24.1$ (acetonide- $\mathrm{CH}_{3}$ ), 24.9 (acetonide- $\mathrm{CH}_{3}$ ), 25.2 (acetonide- $\mathrm{CH}_{3}$ ), 25.4 (acetonide- $\mathrm{CH}_{3}$ ), 26.4 (acetonide$\left.\mathrm{CH}_{3}\right), 26.4$ (acetonide- $\left.\mathrm{CH}_{3}\right), 29.1(17-\mathrm{CH}), 32.4(23-\mathrm{CH}), 32.9\left(12-\mathrm{CH}_{2}\right), 35.6(21-\mathrm{CH}), 37.2\left(24-\mathrm{CH}_{2}\right)$, $38.9(6-\mathrm{CH}), 40.2\left(16-\mathrm{CH}_{2}\right), 44.0(2-\mathrm{CH}), 47.5(5-\mathrm{CH}), 61.2(25-\mathrm{CH}), 66.7\left(27-\mathrm{CH}_{2}\right), 70.6(15-\mathrm{CH}), 72.1$ $(20-\mathrm{CH}), 74.4(22-\mathrm{CH}), 75.5(9-\mathrm{CH}), 77.3(3-\mathrm{CH}$ or $10-\mathrm{CH}), 77.3(3-\mathrm{CH}$ or $10-\mathrm{CH}), 78.3$ (11-CH or 13$\mathrm{CH}), 78.5(11-\mathrm{CH}$ or $13-\mathrm{CH}), 79.0(26-\mathrm{CH}), 85.2(14-\mathrm{CH}), 100.6$ (acetonide-C), 109.0 (acetonide-C), 110.1 (acetonide-C), 124.8 (8-CH), 130.0 (18-CH), 131.1 (19-C), 134.2 (7-CH), 174.9 (1-C), 212.9 (4-C); IR v $3445(\mathrm{w}), 2925(\mathrm{~m}), 2360(\mathrm{w}), 1715(\mathrm{~m}), 1575(\mathrm{w}), 1455(\mathrm{~m}), 1380(\mathrm{~s}), 1220(\mathrm{~s}), 1025(\mathrm{~s}), 885(\mathrm{~m})$, $855(\mathrm{~m}), 685(\mathrm{w}), 510(\mathrm{~m}) \mathrm{cm}^{-1}$; HRMS (ESI): m/z [M + H] ${ }^{+}$Calcd. for $\mathrm{C}_{43} \mathrm{H}_{70} \mathrm{ClO}_{12}$ : 813.45503; Found: 813.45550, m/z [M + Na $]^{+}$Calcd. for $\mathrm{C}_{43} \mathrm{H}_{69} \mathrm{ClNaO}_{12}$ : 835.43698; Found: 835.43717.
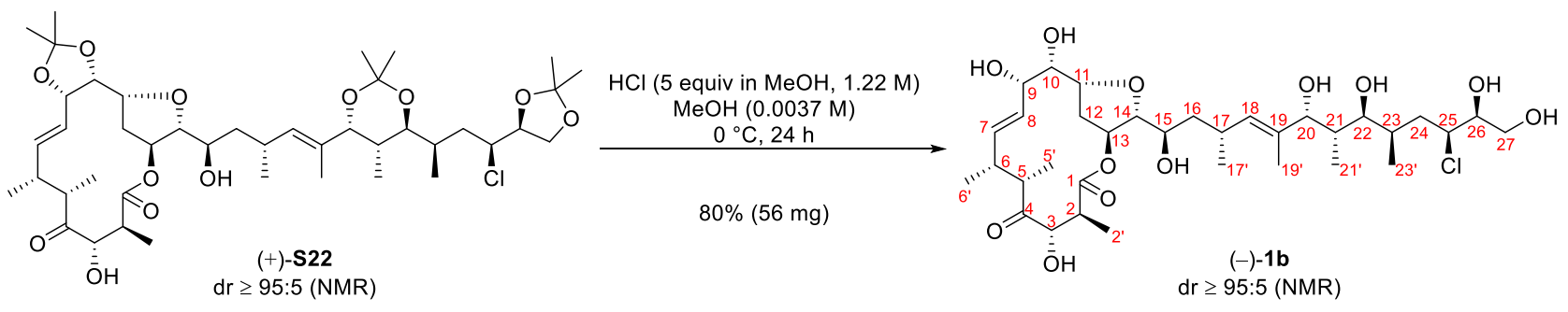

$(\mathbf{1 1 R}, \mathbf{1 3 S}, \mathbf{1 4 R}, \mathbf{1 5 R})$-Lytophilippine A (-)-1b. Note: Overall a total mass of $84 \mathrm{mg}$ was prepared during our total synthesis campaign. A colorless solution of hydrochloric acid $(\mathrm{HCl}, 35 \% \mathrm{~m} / \mathrm{m}$ in water, 1.18 $\mathrm{g} / \mathrm{mL}, 100 \mu \mathrm{L}, 118 \mathrm{mg}$ containing $41 \mathrm{mg} \mathrm{HCl}, 36.46 \mathrm{~g} / \mathrm{mol}, 1.12 \mathrm{mmol})$ in methanol (820 $\mu \mathrm{L})$ was prepared. A fraction of this hydrochloric acid solution $(\mathrm{HCl}$, assumed to be $1.22 \mathrm{M}$ in methanol-water $\{8: 1\})$ was used immediately according to the following procedure: [14]Macrolactone (+)-S22 $\left(\mathrm{C}_{43} \mathrm{H}_{69} \mathrm{ClO}_{12}, 813.46 \mathrm{~g} / \mathrm{mol}, 82 \mathrm{mg}, 101 \mu \mathrm{mol}, 1\right.$ equiv) was dissolved in methanol $(27.2 \mathrm{~mL}, 0.0037 \mathrm{M})$, and the solution was cooled to $0{ }^{\circ} \mathrm{C}$. Hydrochloric acid solution $(\mathrm{HCl}$, assumed to be $1.22 \mathrm{M}$ in methanolwater $\{8: 1\}, 403 \mu \mathrm{L}, 492 \mu \mathrm{mol}, 4.9$ equiv) was added at $0{ }^{\circ} \mathrm{C}$ to afford a colorless reaction mixture. After being stirred for $24 \mathrm{~h}$ at $0{ }^{\circ} \mathrm{C}$, solid $\mathrm{NaHCO}_{3}(847 \mathrm{mg}$ ) and silica gel (approx. $500 \mathrm{mg}$ ) were added slowly at $0{ }^{\circ} \mathrm{C}$ to afford a slurry. Subsequent removal of all volatiles under reduced pressure afforded a powdery white solid that was loaded directly onto a silica gel column. Elution $\left(\mathrm{CH}_{2} \mathrm{Cl}_{2}\right.$-methanol, 20:1 to 5:1) delivered (-)-1b $\left(\mathrm{C}_{34} \mathrm{H}_{57} \mathrm{ClO}_{12}, 693.27 \mathrm{~g} / \mathrm{mol}, 56 \mathrm{mg}, 81 \mu \mathrm{mol}, 80 \%\right.$, dr $\geq 95: 5$ according to NMR evaluation) as a white solid. The configuration of the $7-\mathrm{CH} / 8-\mathrm{CH}$ double bond was assigned by coupling constant analysis: 5.46 (ddd, $J=16.0,3.3,0.6 \mathrm{~Hz}, 1 \mathrm{H}, 8-\mathrm{CH}), 6.08(\mathrm{ddd}, J=15.9,8.8,1.9 \mathrm{~Hz}, 1 \mathrm{H}, 7-\mathrm{CH})$. Our proposal of a [14]macrolide rather than the alternative [16]macrolide structural element is supported by the interpretation of the results of a HMBC experiment. HMBC correlation observed between 13-CH and $1-\mathrm{C}, 3-\mathrm{CH}$ and $1-\mathrm{C}, 2-\mathrm{C}$ and $1-\mathrm{C}, 2^{\prime}-\mathrm{CH}_{3}$ and $1-\mathrm{C}, 2-\mathrm{CH}$ and $13-\mathrm{CH}$ as well as $2{ }^{\prime}-\mathrm{CH}_{3}$ and $13-\mathrm{CH}$. $\mathrm{R}_{\mathrm{f}}$ $0.54\left(\mathrm{CH}_{2} \mathrm{Cl}_{2}-\right.$ methanol, 5:1); m.p. $128.5^{\circ} \mathrm{C} ;[\alpha]_{\mathrm{D}}{ }^{25}=-4.6(c=1, \mathrm{MeOH}) ; \mathrm{IR} \vee 3360(\mathrm{~m}), 2930(\mathrm{~m}), 2495$ (m), 1715 (s), 1455 (m), 1380 (m), 1255 (m), 1045 (s), 975 (s) cm ${ }^{-1} ;$ HRMS (ESI): m/z [M + Na] Calcd. for $\mathrm{C}_{34} \mathrm{H}_{57} \mathrm{ClNaO}_{12}$ : 715.34308; Found: 715.34290.

${ }^{1} \mathrm{H}$ NMR $\left(\mathbf{C D}_{3} \mathrm{OD}, 600 \mathrm{MHz}\right) \delta 0.71\left(\mathrm{~d}, J=7.0 \mathrm{~Hz}, 3 \mathrm{H}, 21^{\prime}-\mathrm{CH}_{3}\right), 0.90\left(\mathrm{~d}, J=6.6 \mathrm{~Hz}, 3 \mathrm{H}, 23{ }^{\prime}-\mathrm{CH}_{3}\right), 0.97$ $\left(\mathrm{d}, J=6.6 \mathrm{~Hz}, 3 \mathrm{H}, 17^{\prime}-\mathrm{CH}_{3}\right), 1.21\left(\mathrm{~d}, J=7.0 \mathrm{~Hz}, 3 \mathrm{H}, 6{ }^{\prime}-\mathrm{CH}_{3}\right), 1.26\left(\mathrm{~d}, J=7.2 \mathrm{~Hz}, 3 \mathrm{H}, 2^{\prime}-\mathrm{CH}_{3}\right), 1.40(\mathrm{~d}, J$ 
$\left.=7.7 \mathrm{~Hz}, 3 \mathrm{H}, 5^{\prime}-\mathrm{CH}_{3}\right), 1.42-1.51\left(\mathrm{~m}, 2 \mathrm{H}, 16-\mathrm{CH}_{2}\right), 1.61\left(\mathrm{~s}, 3 \mathrm{H}, 19 '-\mathrm{CH}_{3}\right), 1.69-1.82\left(\mathrm{~m}, 4 \mathrm{H}, 12-\mathrm{CH}_{2}+21-\right.$ $\left.\mathrm{CH}+24-\mathrm{CH}_{2}\right), 1.95-2.04\left(\mathrm{~m}, 2 \mathrm{H}, 23-\mathrm{CH}+24-\mathrm{CH}_{2}\right), 2.23-2.30(\mathrm{~m}, 1 \mathrm{H}, 6-\mathrm{CH}), 2.56$ (apparent dq, $J=9.6$, $7.2 \mathrm{~Hz}, 1 \mathrm{H}, 2-\mathrm{CH}$ ), 2.62 (apparent dq, $J=9.5,7.0 \mathrm{~Hz}, 1 \mathrm{H}, 17-\mathrm{CH}$ ), 2.99 (apparent qd, $J=7.6,3.1 \mathrm{~Hz}, 1 \mathrm{H}$, 5-CH), 3.59-3.73 (m, 6H, 14-CH+15-CH+22-CH+26-CH+27- $\left.\mathrm{CH}_{2}\right), 3.79$ (ddd, $J=11.4,3.9,2.8 \mathrm{~Hz}, 1 \mathrm{H}$, 11-CH), 4.01 (apparent t, $J=3.2 \mathrm{~Hz}, 1 \mathrm{H}, 10-\mathrm{CH}), 4.23(\mathrm{~d}, J=9.6 \mathrm{~Hz}, 1 \mathrm{H}, 3-\mathrm{CH}), 4.25-4.30$ (m, 1H, 25$\mathrm{CH}), 4.37-4.41(\mathrm{~m}, 2 \mathrm{H}, 9-\mathrm{CH}+20-\mathrm{CH}), 5.27(\mathrm{~d}, J=4.6 \mathrm{~Hz}, 1 \mathrm{H}, 13-\mathrm{CH}), 5.35$ (apparent dt, $J=9.7,1.4$ $\mathrm{Hz}, 1 \mathrm{H}, 18-\mathrm{CH}), 5.46$ (ddd, $J=16.0,3.3,0.6 \mathrm{~Hz}, 1 \mathrm{H}, 8-\mathrm{CH}), 6.08$ (ddd, $J=15.9,8.8,1.9 \mathrm{~Hz}, 1 \mathrm{H}, 7-\mathrm{CH})$, note: The alcohol proton signals $(8 \times)$ were not detectable; ${ }^{13} \mathrm{C} \mathrm{NMR}\left(\mathbf{C D}_{3} \mathrm{OD}, 151 \mathrm{MHz}\right) \delta 9.4\left(211^{\prime}\right.$ $\left.\mathrm{CH}_{3}\right), 13.3\left(233^{\prime}-\mathrm{CH}_{3}\right), 14.6\left(19^{\prime}-\mathrm{CH}_{3}\right), 14.8\left(2^{\prime}-\mathrm{CH}_{3}\right), 17.8\left(5^{\prime}-\mathrm{CH}_{3}\right), 20.9\left(6{ }^{\prime}-\mathrm{CH}_{3}\right), 21.0\left(17^{\prime}-\mathrm{CH}_{3}\right), 29.8$ $(17-\mathrm{CH}), 33.0(23-\mathrm{CH}), 33.2\left(12-\mathrm{CH}_{2}\right), 39.6(21-\mathrm{CH}), 40.0\left(24-\mathrm{CH}_{2}\right), 41.3(6-\mathrm{CH}), 41.8\left(16-\mathrm{CH}_{2}\right), 44.6$ (2-CH), $50.1(5-\mathrm{CH}), 63.0(25-\mathrm{CH}), 64.6\left(27-\mathrm{CH}_{2}\right), 70.3(15-\mathrm{CH}), 71.9(10-\mathrm{CH}), 72.4(9-\mathrm{CH}), 73.4(22-$ $\mathrm{CH}), 75.1(20-\mathrm{CH}), 75.1(26-\mathrm{CH}), 75.8(3-\mathrm{CH}), 77.3(13-\mathrm{CH}), 79.8(11-\mathrm{CH}), 86.5(14-\mathrm{CH}), 128.0$ (8$\mathrm{CH}), 131.1$ (18-CH), 134.7 (7-CH), 136.2 (19-C), 174.9 (1-C), 212.5 (4-C).

${ }^{1} \mathrm{H}$ NMR $\left(\left(\mathbf{C D}_{3}\right)_{2} \mathbf{C O}, 500 \mathrm{MHz}\right) \delta 0.73\left(\mathrm{~d}, J=7.0 \mathrm{~Hz}, 3 \mathrm{H}, 21^{\prime}-\mathrm{CH}_{3}\right), 0.92\left(\mathrm{~d}, J=6.7 \mathrm{~Hz}, 3 \mathrm{H}, 233^{\prime}-\mathrm{CH}_{3}\right)$, $0.94\left(\mathrm{~d}, J=6.6 \mathrm{~Hz}, 3 \mathrm{H}, 17{ }^{\prime}-\mathrm{CH}_{3}\right), 1.16\left(\mathrm{~d}, J=7.0 \mathrm{~Hz}, 3 \mathrm{H}, 6{ }^{\prime}-\mathrm{CH}_{3}\right), 1.26\left(\mathrm{~d}, J=7.2 \mathrm{~Hz}, 3 \mathrm{H}, 2^{\prime}-\mathrm{CH}_{3}\right), 1.40$ $\left(\mathrm{d}, J=7.6 \mathrm{~Hz}, 3 \mathrm{H}, 5{ }^{\prime}-\mathrm{CH}_{3}\right), 1.42-1.48\left(\mathrm{~m}, 2 \mathrm{H}, 16-\mathrm{CH}_{2}\right), 1.59$ (s, 3H, 19'- $\left.\mathrm{CH}_{3}\right), 1.70$ (dd, $J=13.7,4.6 \mathrm{~Hz}$, $\left.1 \mathrm{H}, 12-\mathrm{CH}_{2}\right), 1.72-1.85\left(\mathrm{~m}, 3 \mathrm{H}, 12-\mathrm{CH}_{2}+21-\mathrm{CH}+24-\mathrm{CH}_{2}\right), 1.94-2.02(\mathrm{~m}, 1 \mathrm{H}, 23-\mathrm{CH}), 2.06-2.10(\mathrm{~m}, 1 \mathrm{H}$, 24- $\left.\mathrm{CH}_{2}\right), 2.21-2.29(\mathrm{~m}, 1 \mathrm{H}, 6-\mathrm{CH}), 2.53-2.60(\mathrm{~m}, 1 \mathrm{H}, 2-\mathrm{CH}), 2.60-2.67(\mathrm{~m}, 1 \mathrm{H}, 17-\mathrm{CH}), 2.97-3.02(\mathrm{~m}$, $1 \mathrm{H}, 5-\mathrm{CH}), 3.58-3.69\left(\mathrm{~m}, 5 \mathrm{H}, 14-\mathrm{CH}+15-\mathrm{CH}+22-\mathrm{CH}+27-\mathrm{CH}_{2}\right), 3.71-3.78(\mathrm{~m}, 2 \mathrm{H}, 26-\mathrm{CH}+-\mathrm{OH}), 3.78$ 3.86 (m, 3H, 11-CH+-OH+-OH), 3.93 (br. s, 1H, -OH), 4.00 (br. s, 1H, -OH), 4.02-4.07 (m, 2H, 10-CH+$\mathrm{OH}), 4.15$ (br. s, $1 \mathrm{H},-\mathrm{OH}), 4.30(\mathrm{~d}, J=9.3 \mathrm{~Hz}, 1 \mathrm{H}, 3-\mathrm{CH}), 4.32-4.36(\mathrm{~m}, 1 \mathrm{H}, 25-\mathrm{CH}), 4.37-4.42(\mathrm{~m}, 2 \mathrm{H}$, 9-CH+20-CH), $5.04(\mathrm{~d}, J=9.2 \mathrm{~Hz}, 1 \mathrm{H},-\mathrm{OH}), 5.27(\mathrm{~d}, J=4.5 \mathrm{~Hz}, 1 \mathrm{H}, 13-\mathrm{CH}), 5.38(\mathrm{~d}, J=9.6 \mathrm{~Hz}, 1 \mathrm{H}$, $18-\mathrm{CH}), 5.46(\mathrm{dd}, J=15.9,3.1 \mathrm{~Hz}, 1 \mathrm{H}, 8-\mathrm{CH}), 6.03(\mathrm{ddd}, J=15.9,8.9,1.8 \mathrm{~Hz}, 1 \mathrm{H}, 7-\mathrm{CH}) ;{ }^{13} \mathrm{C} \mathrm{NMR}$ $\left(\left(\mathbf{C D}_{3}\right)_{2} \mathbf{C O}, 126 \mathrm{MHz}\right) \delta 10.1\left(21^{\prime}-\mathrm{CH}_{3}\right), 13.7\left(23^{\prime}-\mathrm{CH}_{3}\right), 14.4\left(19^{\prime}-\mathrm{CH}_{3}\right), 14.7\left(2^{\prime}-\mathrm{CH}_{3}\right), 17.6\left(5^{\prime}-\mathrm{CH}_{3}\right)$, $20.8\left(6^{\prime}-\mathrm{CH}_{3}\right), 21.2\left(17^{\prime}-\mathrm{CH}_{3}\right), 29.4(17-\mathrm{CH}), 32.9(12-\mathrm{CH}), 32.9\left(23-\mathrm{CH}_{2}\right), 39.1(21-\mathrm{CH}), 39.5\left(24-\mathrm{CH}_{2}\right)$, $40.6(6-\mathrm{CH}), 41.5\left(16-\mathrm{CH}_{2}\right), 44.2(2-\mathrm{CH}), 49.6(5-\mathrm{CH}), 63.5(25-\mathrm{CH}), 64.2\left(27-\mathrm{CH}_{2}\right), 70.0(15-\mathrm{CH}), 71.4$ (10-CH), $71.4(9-\mathrm{CH}), 73.2(22-\mathrm{CH}), 74.4(26-\mathrm{CH}), 75.1(20-\mathrm{CH}), 75.6(3-\mathrm{CH}), 76.5(13-\mathrm{CH}), 79.2$ (11$\mathrm{CH}), 85.9$ (14-CH), 127.5 (8-CH), 130.8 (18-CH), 134.0 (7-CH), 136.0 (19-C), 173.1 (1-C), 211.7 (4-C).

${ }^{1} \mathrm{H}$ NMR $\left(\mathbf{C}_{5} \mathbf{D}_{5} \mathbf{N}-C_{3} \mathrm{OD}(\mathbf{1 : 1}), 600 \mathrm{MHz}\right) \delta 0.79\left(\mathrm{~d}, J=6.9 \mathrm{~Hz}, 3 \mathrm{H}, 21{ }^{\prime}-\mathrm{CH}_{3}\right), 0.91(\mathrm{~d}, J=6.6 \mathrm{~Hz}, 3 \mathrm{H}$, $\left.17 '-\mathrm{CH}_{3}\right), 0.94\left(\mathrm{~d}, J=6.7 \mathrm{~Hz}, 3 \mathrm{H}, 23 '-\mathrm{CH}_{3}\right), 1.10\left(\mathrm{~d}, J=7.0 \mathrm{~Hz}, 3 \mathrm{H}, 6{ }^{\prime}-\mathrm{CH}_{3}\right), 1.31$ (d, $J=7.2 \mathrm{~Hz}, 3 \mathrm{H}, 2^{\prime}-$ $\left.\mathrm{CH}_{3}\right), 1.40\left(\mathrm{~d}, J=7.6 \mathrm{~Hz}, 3 \mathrm{H}, 5{ }^{\prime}-\mathrm{CH}_{3}\right), 1.51-1.56\left(\mathrm{~m}, 2 \mathrm{H}, 16-\mathrm{CH}_{2}\right), 1.57\left(\mathrm{~s}, 3 \mathrm{H}, 19 '-\mathrm{CH}_{3}\right), 1.80-1.87(\mathrm{~m}$, $1 \mathrm{H}, 21-\mathrm{CH}), 1.93-2.01\left(\mathrm{~m}, 2 \mathrm{H}, 24-\mathrm{CH}_{2}+12-\mathrm{CH}_{2}\right), 2.03-2.08\left(\mathrm{~m}, 1 \mathrm{H}, 12-\mathrm{CH}_{2}\right), 2.08-2.13(\mathrm{~m}, 1 \mathrm{H}, 23-$ $\mathrm{CH}), 2.14-2.18(\mathrm{~m}, 1 \mathrm{H}, 6-\mathrm{CH}), 2.21\left(\mathrm{ddd}, J=13.6,8.4,4.4 \mathrm{~Hz}, 1 \mathrm{H}, 24-\mathrm{CH}_{2}\right), 2.69-2.79(\mathrm{~m}, 2 \mathrm{H}, 17-$ $\mathrm{CH}+2-\mathrm{CH}), 3.02$ (apparent dq, $J=7.6,2.8 \mathrm{~Hz}, 1 \mathrm{H}, 5-\mathrm{CH}), 3.77-3.81(\mathrm{~m}, 2 \mathrm{H}, 14-\mathrm{CH}+15-\mathrm{CH}), 3.82$ (dd, $J$ $\left.=5.8,4.1 \mathrm{~Hz}, 2 \mathrm{H}, 27-\mathrm{CH}_{2}\right), 3.88(\mathrm{dd}, J=9.1,2.2 \mathrm{~Hz}, 1 \mathrm{H}, 22-\mathrm{CH}), 3.92($ apparent td, $J=6.0,1.7 \mathrm{~Hz}, 1 \mathrm{H}$, 26-CH), 3.98 (apparent dt, $J=11.4,3.2 \mathrm{~Hz}, 1 \mathrm{H}, 11-\mathrm{CH}$ ), 4.19 (apparent t, $J=2.8 \mathrm{~Hz}, 1 \mathrm{H}, 10-\mathrm{CH}$ ), 4.40 $(\mathrm{d}, J=9.6 \mathrm{~Hz}, 1 \mathrm{H}, 3-\mathrm{CH}), 4.50-4.55(\mathrm{~m}, 2 \mathrm{H}, 25-\mathrm{CH}+9-\mathrm{CH}), 4.60$ (apparent s, 1H, 20-CH), $5.45(\mathrm{dd}, J=$ $15.9,3.2 \mathrm{~Hz}, 1 \mathrm{H}, 8-\mathrm{CH}), 5.50-5.55(\mathrm{~m}, 2 \mathrm{H}, 18-\mathrm{CH}+13-\mathrm{CH}), 6.26$ (ddd, $J=15.9,8.7,1.2 \mathrm{~Hz}, 1 \mathrm{H}, 7-\mathrm{CH})$, note: The alcohol proton signals $(8 \times)$ were not detectable; ${ }^{13} \mathrm{C} \mathrm{NMR}\left(\mathbf{C}_{5} \mathbf{D}_{5} \mathbf{N}-\mathbf{C D}_{3} \mathrm{OD}(\mathbf{1 : 1}), 151 \mathrm{MHz}\right) \delta$ $\left.9.9\left(21^{\prime}-\mathrm{CH}_{3}\right), 13.7\left(23^{\prime}-\mathrm{CH}_{3}\right), 14.8(19)^{\prime}-\mathrm{CH}_{3}\right), 15.0\left(2^{\prime}-\mathrm{CH}_{3}\right), 18.0\left(5^{\prime}-\mathrm{CH}_{3}\right), 21.1\left(6{ }^{\prime}-\mathrm{CH}_{3}\right), 21.1\left(17{ }^{\prime}-\mathrm{CH}_{3}\right)$, $29.5(17-\mathrm{CH}), 33.1(23-\mathrm{CH}), 33.4\left(12-\mathrm{CH}_{2}\right), 39.7(21-\mathrm{CH}), 40.2\left(24-\mathrm{CH}_{2}\right), 41.0(6-\mathrm{CH}), 41.9\left(16-\mathrm{CH}_{2}\right)$, $44.6(2-\mathrm{CH}), 50.0(5-\mathrm{CH}), 63.9(25-\mathrm{CH}), 64.7\left(27-\mathrm{CH}_{2}\right), 70.1(15-\mathrm{CH}), 71.9(10-\mathrm{CH}), 72.3(9-\mathrm{CH}), 73.3$ $(22-\mathrm{CH}), 74.8(26-\mathrm{CH}), 75.0(20-\mathrm{CH}), 75.7(3-\mathrm{CH}), 77.3(13-\mathrm{CH}), 79.8(11-\mathrm{CH}), 86.6(14-\mathrm{CH}), 128.4(8-$ $\mathrm{CH}), 131.1$ (18-CH), 134.3 (7-CH), 136.3 (19-C), 174.2 (1-C), 212.5 (4-C).

${ }^{1} \mathrm{H}$ NMR $\left(\left(\mathbf{C D}_{3}\right)_{2} \mathrm{SO}, 500 \mathrm{MHz}\right) \delta 0.52\left(\mathrm{~d}, J=6.9 \mathrm{~Hz}, 3 \mathrm{H}, 21{ }^{\prime}-\mathrm{CH}_{3}\right), 0.77\left(\mathrm{~d}, J=6.5 \mathrm{~Hz}, 3 \mathrm{H}, 23{ }^{\prime}-\mathrm{CH}_{3}\right)$, $0.85\left(\mathrm{~d}, J=6.5 \mathrm{~Hz}, 3 \mathrm{H}, 17^{\prime}-\mathrm{CH}_{3}\right), 1.09-1.17\left(\mathrm{~m}, 6 \mathrm{H}, 6^{\prime}-\mathrm{CH}_{3}+2^{\prime}-\mathrm{CH}_{3}\right), 1.23-1.27\left(\mathrm{~m}, 1 \mathrm{H}, 16-\mathrm{CH}_{2}\right), 1.31$ $\left(\mathrm{d}, J=7.6 \mathrm{~Hz}, 3 \mathrm{H}, 5^{\prime}-\mathrm{CH}_{3}\right), 1.33-1.40\left(\mathrm{~m}, 1 \mathrm{H}, 16-\mathrm{CH}_{2}\right), 1.40-1.53\left(\mathrm{~m}, 5 \mathrm{H}, 12-\mathrm{CH}_{2}+19 '-\mathrm{CH}_{3}+21-\mathrm{CH}\right)$, 1.59-1.71 (m, 2H, 12- $\left.\mathrm{CH}_{2}+24-\mathrm{CH}_{2}\right), 1.75-1.89\left(\mathrm{~m}, 2 \mathrm{H}, 23-\mathrm{CH}+24-\mathrm{CH}_{2}\right), 2.10-2.19(\mathrm{~m}, 1 \mathrm{H}, 6-\mathrm{CH}), 2.39$ (ddd, $J=14.2,9.6,7.3 \mathrm{~Hz}, 1 \mathrm{H}, 2-\mathrm{CH}), 2.51-2.54(\mathrm{~m}, 1 \mathrm{H}, 17-\mathrm{CH}), 2.88(\mathrm{dd}, J=7.7,2.6 \mathrm{~Hz}, 1 \mathrm{H}, 5-\mathrm{CH})$, 3.38-3.46 (m, 5H, 14-CH+15-CH+22-CH+27- $\mathrm{CH}_{2}$ ), 3.53 (apparent q, $\left.J=6.2 \mathrm{~Hz}, 1 \mathrm{H}, 26-\mathrm{CH}\right), 3.56-3.63$ $(\mathrm{m}, 1 \mathrm{H}, 11-\mathrm{CH}), 3.82(\mathrm{~d}, J=1.9 \mathrm{~Hz}, 1 \mathrm{H}, 10-\mathrm{CH}), 4.07$ (apparent t, $J=9.3 \mathrm{~Hz}, 1 \mathrm{H}, 3-\mathrm{CH}), 4.14-4.21(\mathrm{~m}$, $1 \mathrm{H}, 9-\mathrm{CH}), 4.23-4.29$ (m, 2H, 20-CH+25-CH), 4.31-4.38 (m, 2H, -OH+-OH), 4.48 (br. s, 1H, -OH), 4.56 
(br. s, 1H, -OH), $4.60(\mathrm{~d}, J=3.9 \mathrm{~Hz}, 1 \mathrm{H},-\mathrm{OH}), 4.75$ (br. s, $1 \mathrm{H},-\mathrm{OH}), 4.98(\mathrm{~d}, J=5.2 \mathrm{~Hz}, 1 \mathrm{H},-\mathrm{OH}), 5.10$ $(\mathrm{d}, J=4.4 \mathrm{~Hz}, 1 \mathrm{H}, 13-\mathrm{CH}), 5.26(\mathrm{~d}, J=9.5 \mathrm{~Hz}, 1 \mathrm{H}, 18-\mathrm{CH}), 5.35(\mathrm{dd}, J=15.9,2.9 \mathrm{~Hz}, 1 \mathrm{H}, 8-\mathrm{CH}), 5.87$ (ddd, $J=15.9,8.8,1.7 \mathrm{~Hz}, 1 \mathrm{H}, 7-\mathrm{CH}), 6.13$ (br. s, $1 \mathrm{H},-\mathrm{OH}) ;{ }^{13} \mathrm{C}$ NMR $\left((\mathbf{C D})_{2} \mathbf{S O}, 126 \mathrm{MHz}\right) \delta 8.6\left(21^{\prime}-\right.$ $\left.\mathrm{CH}_{3}\right), 12.9\left(233^{\prime}-\mathrm{CH}_{3}\right), 14.3\left(19^{\prime}-\mathrm{CH}_{3}\right), 14.4\left(2^{\prime}-\mathrm{CH}_{3}\right), 17.2\left(5^{\prime}-\mathrm{CH}_{3}\right), 20.4\left(17^{\prime}-\mathrm{CH}_{3}\right), 20.7\left(6^{\prime}-\mathrm{CH}_{3}\right), 27.6$ $(17-\mathrm{CH}), 31.3(23-\mathrm{CH}), 31.6\left(12-\mathrm{CH}_{2}\right), 38.2(21-\mathrm{CH}), 38.8\left(24-\mathrm{CH}_{2}\right), 39.4(6-\mathrm{CH}), 40.6\left(16-\mathrm{CH}_{2}\right), 42.7$ (2-CH), $48.4(5-\mathrm{CH}), 63.0(27-\mathrm{CH}), 63.3\left(25-\mathrm{CH}_{2}\right), 67.9(15-\mathrm{CH}), 70.0(10-\mathrm{CH}), 70.3(22-\mathrm{CH}), 70.5(9-$ $\mathrm{CH}), 71.7(20-\mathrm{CH}), 72.9(26-\mathrm{CH}), 73.6(3-\mathrm{CH}), 75.6(13-\mathrm{CH}), 78.0(11-\mathrm{CH}), 84.7$ (14-CH), $127.4(8-$ $\mathrm{CH}), 129.4$ (18-CH), 132.2 (7-CH), 134.7 (19-C), 172.4 (1-C), 211.1 (4-C).

${ }^{1} \mathrm{H}$ NMR $\left(\mathbf{C}_{5} \mathbf{D}_{5} \mathbf{N}, 500 \mathrm{MHz}\right) \delta 1.06\left(\mathrm{~d}, J=6.4 \mathrm{~Hz}, 3 \mathrm{H}, 17^{\prime}-\mathrm{CH}_{3}\right), 1.11\left(\mathrm{~d}, J=7.0 \mathrm{~Hz}, 3 \mathrm{H}, 211^{\prime}-\mathrm{CH}_{3}\right), 1.21$ $\left(\mathrm{d}, J=7.0 \mathrm{~Hz}, 3 \mathrm{H}, 6^{\prime}-\mathrm{CH}_{3}\right), 1.24\left(\mathrm{~d}, J=6.7 \mathrm{~Hz}, 3 \mathrm{H}, 23{ }^{\prime}-\mathrm{CH}_{3}\right), 1.56\left(\mathrm{~d}, J=7.3 \mathrm{~Hz}, 3 \mathrm{H}, 2^{\prime}-\mathrm{CH}_{3}\right), 1.58(\mathrm{~d}, J$ $\left.=7.6 \mathrm{~Hz}, 3 \mathrm{H}, 5{ }^{\prime}-\mathrm{CH}_{3}\right), 1.74\left(\mathrm{~s}, 3 \mathrm{H}, 19^{\prime}-\mathrm{CH}_{3}\right), 1.78-1.84\left(\mathrm{~m}, 2 \mathrm{H}, 16-\mathrm{CH}_{2}\right), 2.12-2.21(\mathrm{~m}, 1 \mathrm{H}, 21-\mathrm{CH})$, 2.27-2.35 (m, 1H, 6-CH), 2.36-2.44 (m, 1H, 24- $\left.\mathrm{CH}_{2}\right), 2.45-2.53\left(\mathrm{~m}, 2 \mathrm{H}, 23-\mathrm{CH}+12-\mathrm{CH}_{2}\right), 2.59-2.67(\mathrm{~m}$, $1 \mathrm{H}, 12-\mathrm{CH}_{2}$ ), 2.70 (ddd, $\left.J=13.6,8.2,5.0 \mathrm{~Hz}, 1 \mathrm{H}, 24-\mathrm{CH}_{2}\right), 3.01-3.11(\mathrm{~m}, 1 \mathrm{H}, 17-\mathrm{CH}), 3.15$ (apparent dq, $J=9.5,7.2 \mathrm{~Hz}, 1 \mathrm{H}, 2-\mathrm{CH}$ ), 3.26 (apparent qd, $J=7.5,2.9 \mathrm{~Hz}, 1 \mathrm{H}, 5-\mathrm{CH}), 4.07-4.12(\mathrm{~m}, 1 \mathrm{H}, 15-\mathrm{CH})$, $4.20(\mathrm{~d}, J=5.5 \mathrm{~Hz}, 1 \mathrm{H}, 14-\mathrm{CH}), 4.22-4.28\left(\mathrm{~m}, 2 \mathrm{H}, 27-\mathrm{CH}_{2}\right), 4.30-4.38(\mathrm{~m}, 2 \mathrm{H}, 22-\mathrm{CH}+26-\mathrm{CH}), 4.44$ (apparent dt, $J=11.3,3.4 \mathrm{~Hz}, 1 \mathrm{H}, 11-\mathrm{CH}), 4.59$ (apparent t, $J=2.9 \mathrm{~Hz}, 1 \mathrm{H}, 10-\mathrm{CH}$ ), 4.79 (apparent $\mathrm{t}, J=$ $9.0 \mathrm{~Hz}, 1 \mathrm{H}, 3-\mathrm{CH}), 4.89$ (d, $J=1.2 \mathrm{~Hz}, 1 \mathrm{H}, 9-\mathrm{CH}), 5.00(\mathrm{ddd}, J=9.3,4.9,2.0 \mathrm{~Hz}, 1 \mathrm{H}, 25-\mathrm{CH}), 5.06$ (apparent s, 1H, 20-CH), $5.68(\mathrm{dd}, J=15.7,2.9 \mathrm{~Hz}, 1 \mathrm{H}, 8-\mathrm{CH}), 5.84-5.96(\mathrm{~m}, 2 \mathrm{H}, 18-\mathrm{CH}+-\mathrm{OH}), 5.99-$ 6.12 (m, 3H, 13-CH+-OH+-OH), 6.37 (br. s, 2H, -OH+-OH), 6.54-6.72 (m, 2H, 7-CH+-OH), 6.90 (br. s, $1 \mathrm{H},-\mathrm{OH}), 7.81(\mathrm{~d}, J=8.9 \mathrm{~Hz}, 1 \mathrm{H},-\mathrm{OH}) ;{ }^{13} \mathrm{C}$ NMR $\left(\mathbf{C}_{5} \mathbf{D}_{5} \mathbf{N}, 126 \mathrm{MHz}\right) \delta 10.4\left(21^{\prime}-\mathrm{CH}_{3}\right), 14.0\left(23^{\prime}-\mathrm{CH}_{3}\right)$, $15.0\left(19^{\prime}-\mathrm{CH}_{3}\right), 15.2\left(2^{\prime}-\mathrm{CH}_{3}\right), 18.0\left(5^{\prime}-\mathrm{CH}_{3}\right), 20.8\left(17{ }^{\prime}-\mathrm{CH}_{3}\right), 21.1\left(6 '-\mathrm{CH}_{3}\right), 29.2(17-\mathrm{CH}), 33.2(12-\mathrm{CH})$, $33.3\left(23-\mathrm{CH}_{2}\right), 39.8(21-\mathrm{CH}), 40.4\left(24-\mathrm{CH}_{2}\right), 40.7(6-\mathrm{CH}), 42.0\left(16-\mathrm{CH}_{2}\right), 44.8(2-\mathrm{CH}), 49.9(5-\mathrm{CH}), 64.8$ $(25-\mathrm{CH}), 65.0\left(27-\mathrm{CH}_{2}\right), 70.3(15-\mathrm{CH}), 72.2(10-\mathrm{CH}), 72.4(9-\mathrm{CH}), 73.4(22-\mathrm{CH}), 74.7(20-\mathrm{CH}), 75.1$ (26-CH), $75.9(3-\mathrm{CH}), 77.8(13-\mathrm{CH}), 80.0(11-\mathrm{CH}), 86.6(14-\mathrm{CH}), 128.8(8-\mathrm{CH}), 131.1(18-\mathrm{CH}), 133.9$ (7-CH), 136.5 (19-C), 173.7 (1-C), 212.6 (4-C). 
${ }^{1} \mathbf{H}$ NMR Mosher Ester Analysis of 20-CH. To collect evidence in support of the absolute configuration of 20-CH, the configurational correlation model of Mosher was used. ${ }^{19}$ The diagnostic ${ }^{1} \mathrm{H}$ NMR chemical shifts of the $(R)$ - and $(S)$-Mosher esters (-)-S16 and (-)-S17 were used to calculate $\Delta \delta=\delta(20 ?, S)$ $\delta(20 ?, R)$ (Table SI-1-4). The configurational correlation model of Mosher supports our (20S) configurational assignment (Figure SI-1-2).

Figure SI-1-1. ${ }^{1} \mathrm{H}$ NMR $\left(\mathrm{CDCl}_{3}, 500 \mathrm{MHz}\right.$ for $(S)-(-)-S 17,600 \mathrm{MHz}$ for $\left.(R)-(-)-\mathbf{S 1 6}\right)$ chemical shift assignment of $(S)-(-)-$ S17 and $(R)-(-)-$ S16.

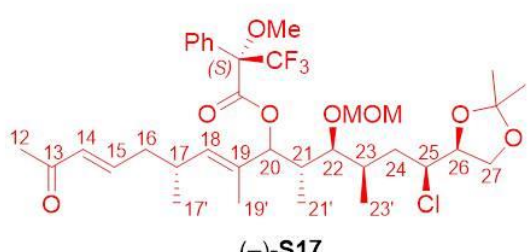

$(-)-\mathbf{S 1 7}$

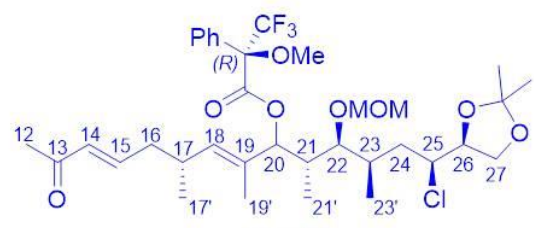

$(-)-\mathbf{S 1 6}$

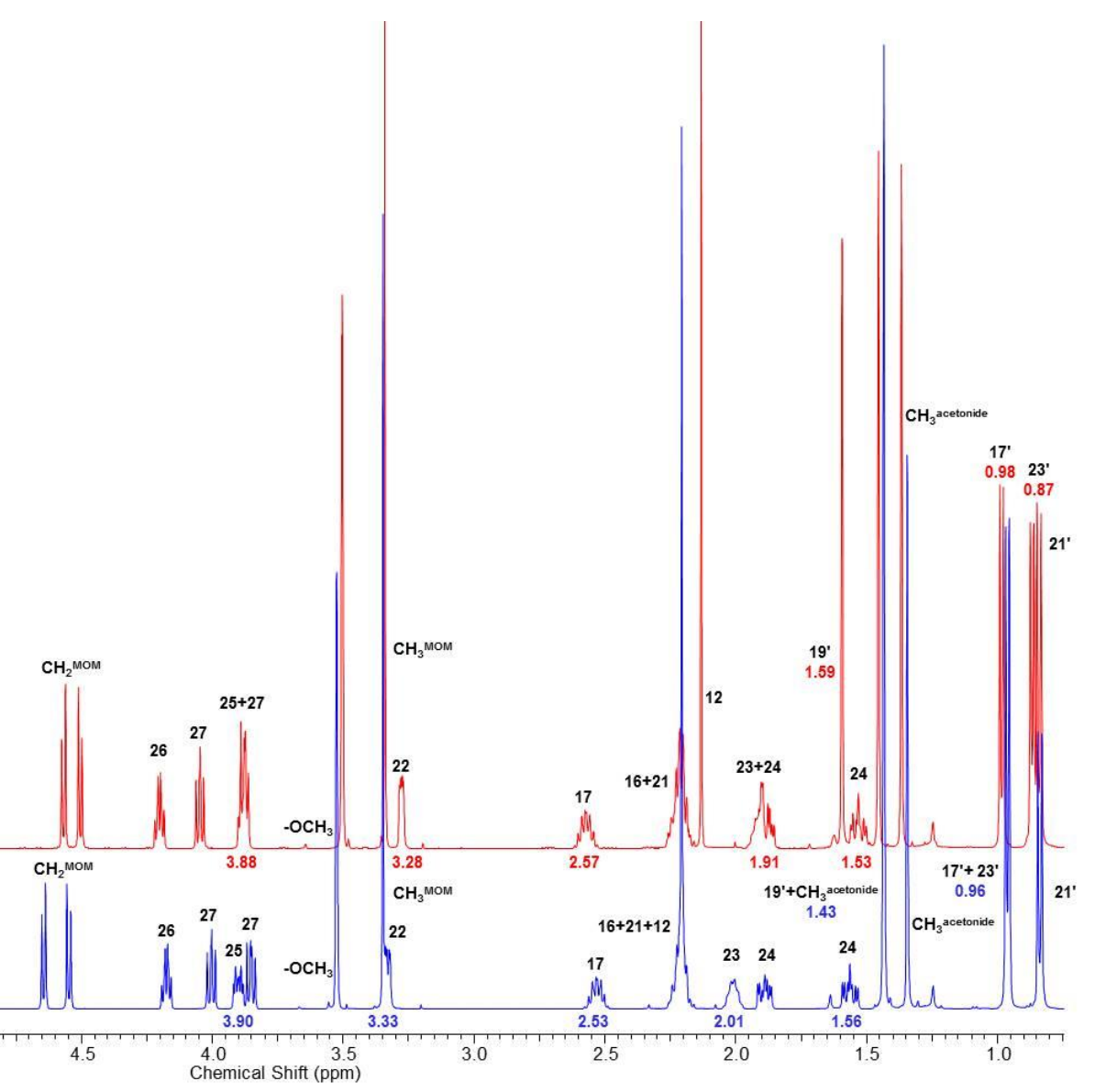

Table SI-1-4. Calculation of $\Delta \delta=\delta(20 ?, S)-\delta(20 ?, R)\left[\mathrm{CDCl}_{3}, 500 \mathrm{MHz}\right.$ for (-)-S17 $(20$ ? ,S), $600 \mathrm{MHz}$ for $(-)-\mathbf{S 1 6}(20 ?, R)]$.

\begin{tabular}{cccccccccc}
\hline$\delta[\mathrm{ppm}]$ & $18-\mathrm{CH}$ & $25-\mathrm{CH}$ & $22-\mathrm{CH}$ & $17-\mathrm{CH}$ & $23-\mathrm{CH}$ & $24-\mathrm{CH}_{2}$ & $19 '-\mathrm{CH}_{3}$ & $17^{\prime}-\mathrm{CH}_{3}$ & $23^{\prime}-\mathrm{CH}_{3}$ \\
\hline$(-)-\mathbf{S 1 7}(20 ?, S)$ & 5.42 & 3.88 & 3.28 & 2.57 & 1.91 & 1.53 & 1.59 & 0.98 & 0.87 \\
$(-)-\mathbf{S 1 6}(20 ?, R)$ & 5.37 & 3.90 & 3.33 & 2.53 & 2.01 & 1.56 & 1.43 & 0.96 & 0.96 \\
$\Delta \delta=\delta(\boldsymbol{S})-\delta(R)$ & +0.05 & -0.02 & -0.05 & +0.04 & -0.1 & -0.03 & +0.16 & +0.02 & -0.09 \\
\hline
\end{tabular}

Figure SI-1-2. Application of Mosher's configurational correlation model for 20-CH using the data basis tabulated in Table SI-1-4.

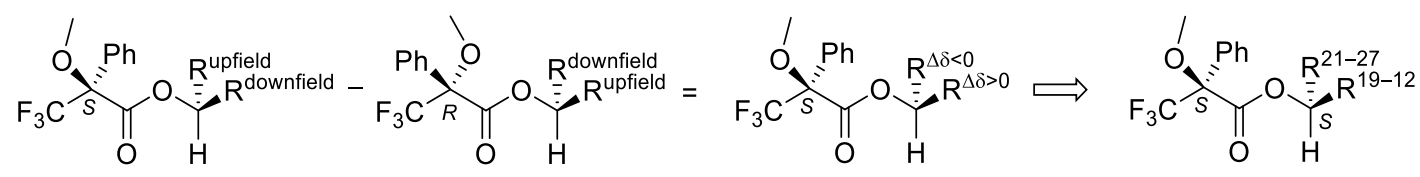

${ }^{1}$ H NMR Mosher Ester Analysis of 11-CH. To collect evidence in support of the absolute configuration of $11-\mathrm{CH}$, the configurational correlation model of Mosher was used. The diagnostic ${ }^{1} \mathrm{H}$ NMR chemical 
shifts of the $(R)$ - and $(S)$-Mosher esters $(-)$-S18 and $(-)$-S19 were used to calculate $\Delta \delta=\delta(11 ?, S)-$ $\delta(11 ?, R)$ (Table SI-1-5). The configurational correlation model of Mosher supports our $(11 R)$ configurational assignment (Figure SI-1-4).

Figure SI-1-3. ${ }^{1} \mathrm{H}$ NMR $\left(\mathrm{CDCl}_{3}, 600 \mathrm{MHz}\right.$ for $(S)-(-)-S 19,500 \mathrm{MHz}$ for $(R)-(-)-$ S18 $)$ chemical shift assignment of $(S)-(-)-$ S19 and $(R)-(-)-$ S18.

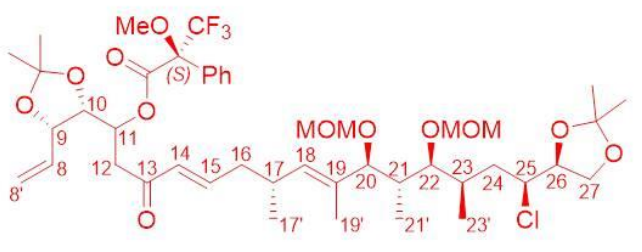

$(-)-\mathbf{S 1 9}$

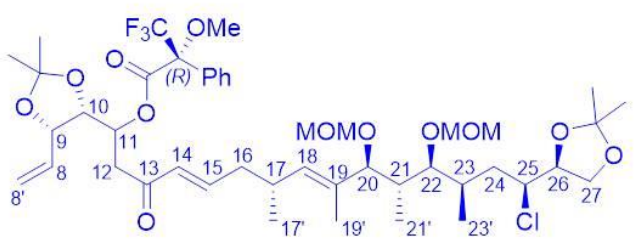

$(-)$-S18
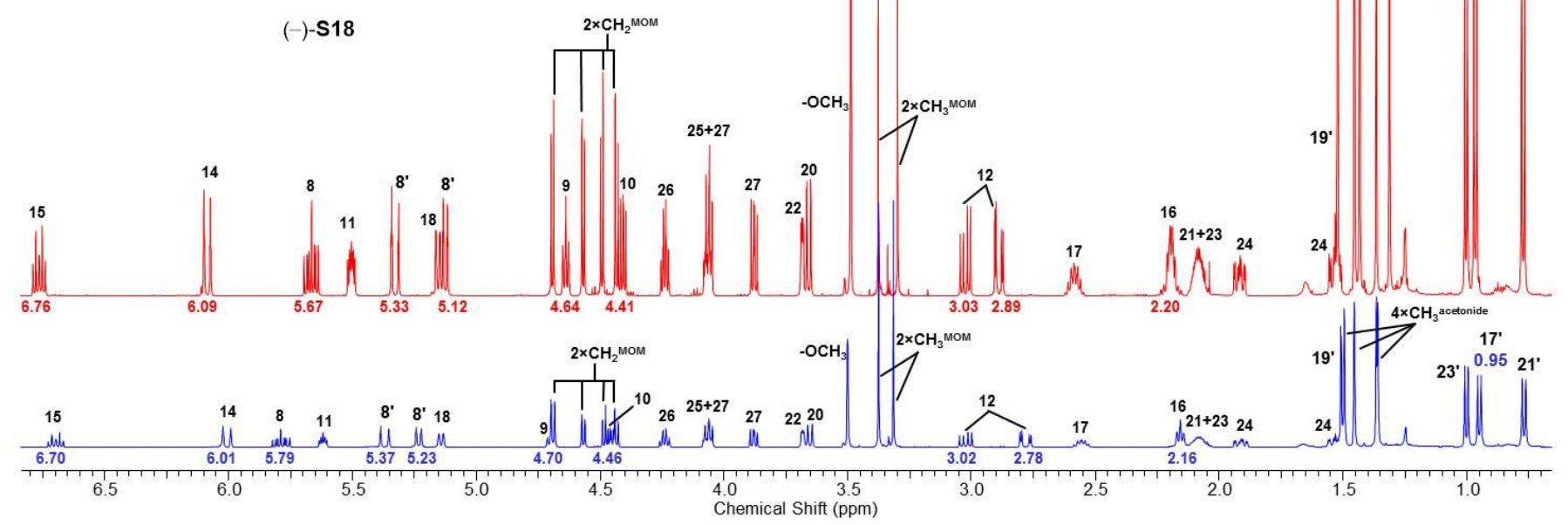

Table SI-1-5. Calculation of $\Delta \delta=\delta(11 ?, S)-\delta(11 ?, R)\left[\mathrm{CDCl}_{3}, 600 \mathrm{MHz}\right.$ for $(-)-\mathrm{S} 19(11 ?, S), 500 \mathrm{MHz}$ for $(-)-\mathbf{S 1 8}(11 ?, R)]$.

\begin{tabular}{ccccccccccccc}
\hline$\delta[\mathrm{ppm}]$ & $15-\mathrm{CH}$ & $14-\mathrm{CH}$ & $8-\mathrm{CH}$ & $8^{\prime}-\mathrm{CH}_{2}$ & $8^{\prime}-\mathrm{CH}_{2}$ & $9-\mathrm{CH}$ & $10-\mathrm{CH}$ & $12-\mathrm{CH}_{2}$ & $12-\mathrm{CH}_{2}$ & $16-\mathrm{CH}_{2}$ & $17-\mathrm{CH}_{3}$ \\
\hline$(-)-\mathbf{S 1 9}(11 ?, S)$ & 6.76 & 6.09 & 5.67 & 5.33 & 5.12 & 4.64 & 4.41 & 3.03 & 2.89 & 2.20 & 0.97 \\
$(-)-\mathbf{S 1 8}(11 ?, R)$ & 6.70 & 6.01 & 5.79 & 5.37 & 5.23 & 4.70 & 4.46 & 3.02 & 2.78 & 2.16 & 0.95 \\
$\Delta \delta=\delta(S)-\delta(R)$ & +0.06 & +0.08 & -0.12 & -0.04 & -0.11 & -0.06 & -0.05 & +0.01 & +0.11 & +0.04 & +0.02 \\
\hline
\end{tabular}

Figure SI-1-4. Application of Mosher's configurational correlation model for 11-CH using the data basis tabulated in Table SI-1-5.

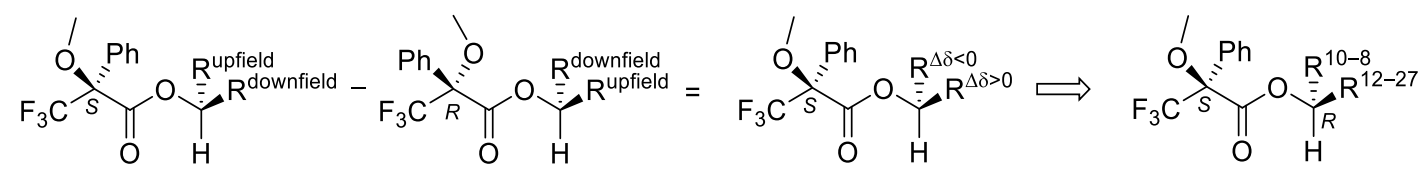


Assignment of the Relative Configuration of 11-CH and 13-CH by ${ }^{13} \mathrm{C}$ NMR Acetonide Analysis. To collect evidence in support of the predicted relative configuration of 11-CH and 13-CH of (-)-S20, we analyzed the ${ }^{13} \mathrm{C}$ NMR chemical shifts of the acetonide functionality according to Rychnovsky (Figure SI1-5). ${ }^{20}$ The ${ }^{13} \mathrm{C}$ NMR acetonide analysis of (-)-S20 suggests an 11,13-syn configuration.

Figure SI-1-5. Rychnovsky analysis of (-)-S20.
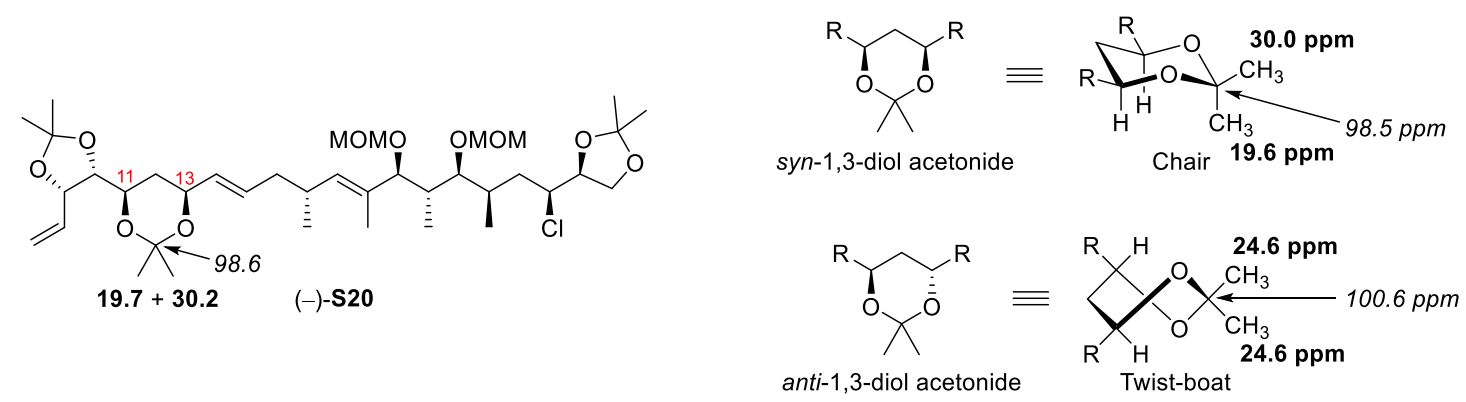

Assignment of the Relative Configuration of 20-CH and 22-CH by ${ }^{13} \mathrm{C}$ NMR Acetonide Analysis To collect evidence in support of the predicted relative configuration of $20-\mathrm{CH}$ and $22-\mathrm{CH}$ of $(-)-17$, we analyzed the ${ }^{13} \mathrm{C}$ NMR chemical shifts of the acetonide functionality according to Rychnovsky (Figure SI1-6). ${ }^{20}$ The ${ }^{13} \mathrm{C}$ NMR acetonide analysis of (-)-17 suggests a 20,22-anti configuration.

Figure SI-1-6. Rychnovsky analysis of (-)-17.
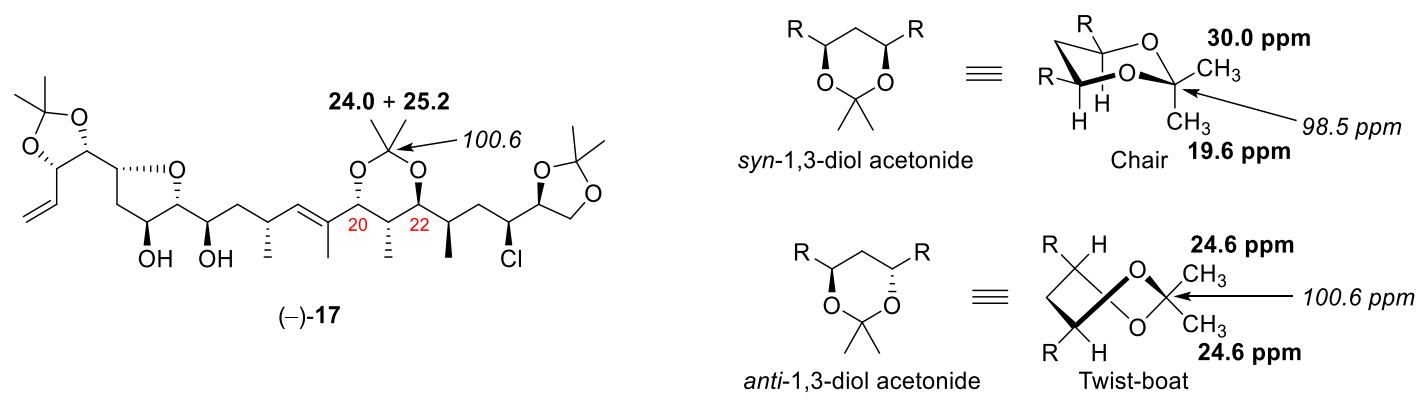

Assignment of the Relative Configuration of 13-CH and 15-CH by ${ }^{13} \mathrm{C}$ NMR Acetonide Analysis To collect evidence in support of the predicted relative configuration of $13-\mathrm{CH}$ and $15-\mathrm{CH}$ of $(-)-16$, we analyzed the ${ }^{13} \mathrm{C}$ NMR chemical shifts of the acetonide functionality according to Rychnovsky (Figure SI$1-7) .{ }^{20}$ The ${ }^{13} \mathrm{C}$ NMR acetonide analysis of (-)-16 suggests a 13,15-anti configuration.

Figure SI-1-7. Rychnovsky analysis of (-)-16.
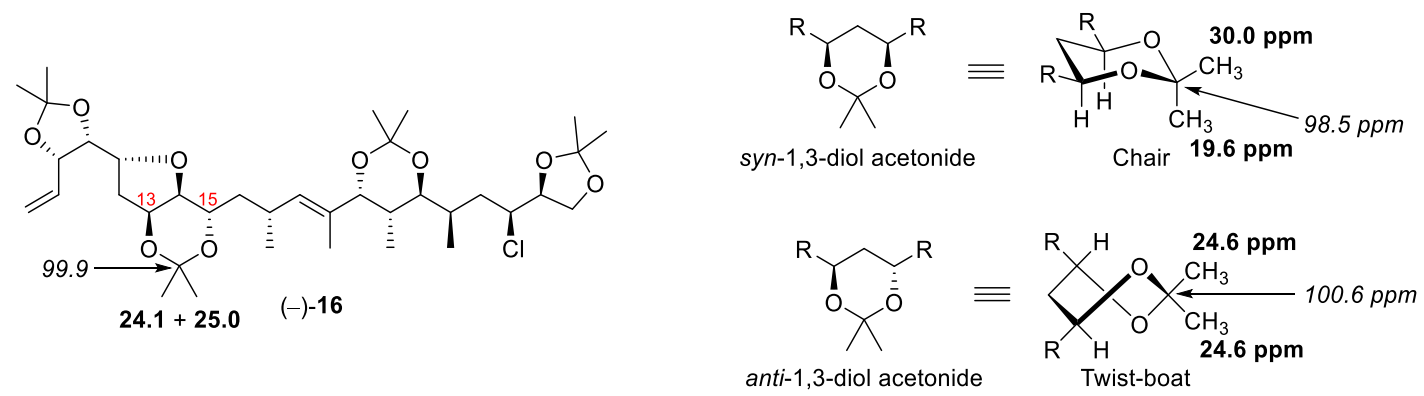
Table SI-1-6. "H NMR data basis for the molecule named "lytophilippine A" originally isolated by Rezanka et al. (2004), ${ }^{21}$ first synthesized by Lee et al. (2011), ${ }^{8}$ and later synthesized by Hiersemann et al. (this letter). Notes: (a) Solvent used for the NMR experiments by Rezanka et al. was not reported; the primary data are no longer available. (b) Tabulated proton assignment according to Lee was deduced from ${ }^{1} \mathrm{H}^{1} \mathrm{H}$ COSY spectrum provided in the Supporting Information. (c) "Our" synthetic lytophilippine A was insoluble in $\mathrm{CD}_{3} \mathrm{CN}, \mathrm{CDCl}_{3}, \mathrm{C}_{6} \mathrm{D}_{6}$, and $\mathrm{D}_{2} \mathrm{O}$.

\begin{tabular}{|c|c|c|c|c|c|c|c|}
\hline \multirow{4}{*}{$\mathrm{H}$ at $\mathrm{C}$} & $\delta[\mathrm{ppm}]$ & $\delta[\mathrm{ppm}]$ & $\delta[\mathrm{ppm}]$ & $\delta[\mathrm{ppm}]$ & $\delta[\mathrm{ppm}]$ & $\delta[\mathrm{ppm}]$ & $\delta[\mathrm{ppm}]$ \\
\hline & $500 \mathrm{MHZ}$ & $600 \mathrm{MHz}$ & $600 \mathrm{MHz}$ & $500 \mathrm{MHz}$ & $600 \mathrm{MHz}$ & $500 \mathrm{MHz}$ & $500 \mathrm{MHz}$ \\
\hline & Řezanka & Lee & Hiersemann & Hiersemann & Hiersemann & Hiersemann & Hiersemann \\
\hline & unreported & $\mathrm{CD}_{3} \mathrm{OD}$ & $\mathrm{CD}_{3} \mathrm{OD}$ & $\left(\mathrm{CD}_{3}\right)_{2} \mathrm{CO}$ & $\mathrm{C}_{5} \mathrm{D}_{5} \mathrm{~N}-\mathrm{CD}_{3} \mathrm{OD}(1: 1)$ & $\left(\mathrm{CD}_{3}\right)_{2} \mathrm{SO}$ & $\mathrm{C}_{5} \mathrm{D}_{5} \mathrm{~N}$ \\
\hline 2 & 2.53 & 2.72 & 2.56 & 2.56 & 2.75 & 2.39 & 3.15 \\
\hline $2^{\prime}$ & 1.31 & 1.20 & 1.26 & 1.26 & 1.31 & 1.14 & 1.56 \\
\hline 3 & 4.39 & 4.30 & 4.23 & 4.30 & 4.40 & 4.07 & 4.79 \\
\hline 5 & 2.84 & 2.94 & 2.99 & 2.99 & 3.02 & 2.88 & 3.26 \\
\hline $5^{\prime}$ & 0.94 & 1.28 & 1.40 & 1.40 & 1.40 & 1.31 & 1.58 \\
\hline 6 & 2.48 & 2.28 & 2.27 & 2.25 & 2.16 & 2.14 & 2.31 \\
\hline $6^{\prime}$ & 1.07 & 1.16 & 1.21 & 1.16 & 1.10 & 1.12 & 1.21 \\
\hline 7 & 5.55 & 6.07 & 6.08 & 6.03 & 6.26 & 5.87 & 6.66 \\
\hline 8 & 5.38 & 5.59 & 5.46 & 5.46 & 5.45 & 5.35 & 5.68 \\
\hline 9 & 4.12 & 3.79 & 4.39 & 4.39 & 4.53 & 4.19 & 4.89 \\
\hline 10 & 3.74 & 3.66 & 4.01 & 4.05 & 4.19 & 3.82 & 4.59 \\
\hline 11 & 3.95 & 3.58 & 3.79 & 3.81 & 3.98 & 3.59 & 4.44 \\
\hline $12 \mathrm{a}$ & 2.11 & 1.64 & 1.78 & 1.80 & 2.06 & 1.63 & 2.63 \\
\hline $12 b$ & 1.87 & 1.43 & 1.73 & 1.70 & 1.99 & 1.43 & 2.48 \\
\hline 13 & 5.10 & 5.26 & 5.27 & 5.27 & 5.54 & 5.10 & 6.04 \\
\hline 14 & 3.66 & 3.79 & 3.63 & 3.66 & 3.79 & 3.42 & 4.20 \\
\hline 15 & 4.02 & 3.45 & 3.67 & 3.65 & 3.79 & 3.38 & 4.09 \\
\hline $16 a$ & 1.39 & 1.48 & 1.46 & 1.43 & 1.54 & 1.35 & 1.81 \\
\hline $16 b$ & 1.22 & 1.38 & 1.46 & 1.43 & 1.54 & 1.25 & 1.81 \\
\hline 17 & 2.81 & 2.79 & 2.62 & 2.63 & 2.73 & 2.51 & 3.06 \\
\hline $17^{\prime}$ & 0.99 & 0.99 & 0.97 & 0.94 & 0.91 & 0.85 & 1.06 \\
\hline 18 & 5.05 & 5.22 & 5.35 & 5.38 & 5.52 & 5.26 & 5.88 \\
\hline $19^{\prime}$ & 1.60 & 1.61 & 1.61 & 1.59 & 1.57 & 1.46 & 1.74 \\
\hline 20 & 4.45 & 4.41 & 4.39 & 4.39 & 4.60 & 4.25 & 5.06 \\
\hline 21 & 2.57 & 1.76 & 1.74 & 1.78 & 1.84 & 1.49 & 2.16 \\
\hline $21^{\prime}$ & 0.98 & 0.70 & 0.71 & 0.73 & 0.79 & 0.52 & 1.11 \\
\hline 22 & 4.00 & 3.65 & 3.64 & 3.62 & 3.88 & 3.43 & 4.34 \\
\hline 23 & 1.84 & 1.99 & 1.99 & 1.98 & 2.10 & 1.81 & 2.48 \\
\hline $23^{\prime}$ & 1.08 & 0.90 & 0.90 & 0.92 & 0.94 & 0.77 & 1.24 \\
\hline $24 a$ & 1.88 & 1.76 & 1.78 & 1.75 & 1.96 & 1.66 & 2.40 \\
\hline $24 b$ & 1.92 & 1.99 & 1.98 & 2.08 & 2.21 & 1.85 & 2.70 \\
\hline 25 & 4.24 & 4.26 & 4.28 & 4.34 & 4.52 & 4.27 & 5.00 \\
\hline 26 & 4.22 & 3.70 & 3.70 & 3.74 & 3.92 & 3.53 & 4.34 \\
\hline $27 \mathrm{a}$ & 4.01 & 3.58 & 3.61 & 3.63 & 3.82 & 3.38 & 4.24 \\
\hline $27 b$ & 4.26 & 3.65 & 3.65 & 3.63 & 3.82 & 3.38 & 4.24 \\
\hline
\end{tabular}


Synthesis of a Diastereomer of the Marine Macrolide Lytophilippine A

Table SI-1-7. ${ }^{1} \mathrm{H}$ NMR chemical shift deviation $(\Delta \delta)$ in different solvents for synthetic $(11 R, 13 S, 14 R, 15 R)$-lytophilippine A (1b).

\begin{tabular}{|c|c|c|c|c|c|}
\hline \multirow{4}{*}{$\mathrm{H}$ at $\mathrm{C}$} & $\delta[\mathrm{ppm}]$ & $\Delta \delta[\mathrm{ppm}]$ & $\Delta \delta[\mathrm{ppm}]$ & $\Delta \delta[\mathrm{ppm}]$ & $\Delta \delta[\mathrm{ppm}]$ \\
\hline & $600 \mathrm{MHz}$ & $500 \mathrm{MHz}$ & $600 \mathrm{MHz}$ & $500 \mathrm{MHz}$ & $500 \mathrm{MHz}$ \\
\hline & $1 \mathbf{b}$ & $\mathbf{1 b}$ & $1 b$ & $1 b$ & $\mathbf{1 b}$ \\
\hline & $\mathrm{CD}_{3} \mathrm{OD}$ & $\left(\mathrm{CD}_{3}\right)_{2} \mathrm{CO}$ & $\mathrm{C}_{5} \mathrm{D}_{5} \mathrm{~N}-\mathrm{CD}_{3} \mathrm{OD}(1: 1)$ & $\left(\mathrm{CD}_{3}\right)_{2} \mathrm{SO}$ & $\mathrm{C}_{5} \mathrm{D}_{5} \mathrm{~N}$ \\
\hline 2 & 2.56 & 0 & +0.19 & -0.17 & +0.59 \\
\hline $2^{\prime}$ & 1.26 & 0 & +0.05 & -0.12 & +0.30 \\
\hline 3 & 4.23 & +0.07 & +0.17 & -0.16 & +0.56 \\
\hline 5 & 2.99 & 0 & +0.03 & -0.11 & +0.27 \\
\hline $5^{\prime}$ & 1.40 & 0 & 0 & -0.09 & +0.18 \\
\hline 6 & 2.27 & -0.02 & -0.11 & -0.13 & +0.04 \\
\hline $6^{\prime}$ & 1.21 & -0.05 & -0.11 & -0.09 & 0 \\
\hline 7 & 6.08 & -0.05 & +0.18 & -0.21 & +0.58 \\
\hline 8 & 5.46 & 0 & -0.01 & -0.11 & +0.22 \\
\hline 9 & 4.39 & 0 & +0.14 & -0.20 & +0.50 \\
\hline 10 & 4.01 & +0.04 & +0.18 & -0.19 & +0.58 \\
\hline 11 & 3.79 & +0.02 & +0.19 & -0.20 & +0.65 \\
\hline $12 \mathrm{a}$ & 1.78 & +0.02 & +0.28 & -0.15 & +0.85 \\
\hline $12 \mathrm{~b}$ & 1.73 & -0.03 & +0.26 & -0.30 & +0.75 \\
\hline 13 & 5.27 & 0 & +0.27 & -0.17 & +0.77 \\
\hline 14 & 3.63 & +0.03 & +0.16 & -0.21 & +0.57 \\
\hline 15 & 3.67 & -0.02 & +0.12 & -0.29 & +0.42 \\
\hline $16 a$ & 1.46 & -0.03 & +0.08 & -0.11 & +0.35 \\
\hline $16 b$ & 1.46 & -0.03 & +0.08 & -0.21 & +0.35 \\
\hline 17 & 2.62 & +0.01 & +0.11 & -0.11 & +0.44 \\
\hline $17^{\prime}$ & 0.97 & -0.03 & -0.06 & -0.12 & +0.09 \\
\hline 18 & 5.35 & +0.03 & +0.17 & -0.09 & +0.53 \\
\hline $19^{\prime}$ & 1.61 & -0.02 & -0.04 & -0.15 & +0.13 \\
\hline 20 & 4.39 & 0 & +0.21 & -0.14 & +0.67 \\
\hline 21 & 1.74 & +0.04 & +0.10 & -0.25 & +0.42 \\
\hline $21^{\prime}$ & 0.71 & +0.02 & +0.08 & -0.19 & +0.40 \\
\hline 22 & 3.64 & -0.02 & +0.24 & -0.21 & +0.70 \\
\hline 23 & 1.99 & -0.01 & +0.11 & -0.18 & +0.49 \\
\hline $23^{\prime}$ & 0.90 & +0.02 & +0.04 & -0.13 & +0.34 \\
\hline $24 a$ & 1.78 & -0.03 & +0.18 & -0.12 & +0.62 \\
\hline $24 b$ & 1.98 & +0.10 & +0.23 & -0.13 & +0.72 \\
\hline 25 & 4.28 & +0.06 & +0.24 & -0.01 & +0.72 \\
\hline 26 & 3.70 & +0.04 & +0.22 & -0.17 & +0.64 \\
\hline $27 \mathrm{a}$ & 3.61 & +0.02 & +0.21 & -0.23 & +0.63 \\
\hline $27 \mathrm{~b}$ & 3.65 & -0.02 & +0.17 & -0.27 & +0.59 \\
\hline
\end{tabular}


Table SI-1-8. ${ }^{13} \mathrm{C}$ NMR data basis for the molecule named "lytophilippine A" originally isolated by Rezanka et al. (2004), ${ }^{21}$ first synthesized by Lee et al. (2011), ${ }^{8}$ and later synthesized by Hiersemann et al. (this letter). Notes: (a) Solvent used for the NMR experiments by Rezanka et al. was not reported; the primary data are no longer available. (b) "Our" synthetic lytophilippine A was insoluble in $\mathrm{CD}_{3} \mathrm{CN}$, $\mathrm{CDCl}_{3}, \mathrm{C}_{6} \mathrm{D}_{6}$, and $\mathrm{D}_{2} \mathrm{O}$.

\begin{tabular}{|c|c|c|c|c|c|c|}
\hline carbon atom & $\begin{array}{c}\delta[\mathrm{ppm}] \\
126 \mathrm{Mhz} \\
\text { Rezanka } \\
\text { unreported } \\
\end{array}$ & $\begin{array}{c}\delta[\mathrm{ppm}] \\
151 \mathrm{MHz} \\
\text { Hiersemann } \\
\mathrm{CD}_{3} \mathrm{OD} \\
\end{array}$ & $\begin{array}{c}\delta[\mathrm{ppm}] \\
126 \mathrm{MHz} \\
\text { Hiersemann } \\
\left(\mathrm{CD}_{3}\right)_{2} \mathrm{CO} \\
\end{array}$ & $\begin{array}{c}\delta[\mathrm{ppm}] \\
151 \mathrm{MHz} \\
\text { Hiersemann } \\
\mathrm{C}_{5} \mathrm{D}_{5} \mathrm{~N}-\mathrm{CD}_{3} \mathrm{OD}(1: 1) \\
\end{array}$ & $\begin{array}{c}\delta[\mathrm{ppm}] \\
126 \mathrm{MHz} \\
\text { Hiersemann } \\
\left(\mathrm{CD}_{3}\right)_{2} \mathrm{SO} \\
\end{array}$ & $\begin{array}{c}\delta[\mathrm{ppm}] \\
126 \mathrm{MHz} \\
\text { Hiersemann } \\
\mathrm{C}_{5} \mathrm{D}_{5} \mathrm{~N} \\
\end{array}$ \\
\hline 1 & 174.5 & 174.9 & 173.1 & 174.2 & 172.4 & 173.7 \\
\hline 2 & 38.5 & 44.6 & 44.2 & 44.6 & 42.7 & 44.8 \\
\hline $2^{\prime}$ & 8.5 & 14.8 & 14.7 & 15.0 & 14.4 & 15.2 \\
\hline 3 & 84.0 & 75.8 & 75.6 & 75.7 & 73.6 & 75.9 \\
\hline 4 & 211.3 & 212.5 & 211.7 & 212.5 & 211.1 & 212.6 \\
\hline 5 & 44.9 & 50.1 & 49.6 & 50.0 & 48.4 & 49.9 \\
\hline $5^{\prime}$ & 11.6 & 17.8 & 17.6 & 18.0 & 17.2 & 18.0 \\
\hline 6 & 33.8 & 41.3 & 40.6 & 41.0 & 39.4 & 40.7 \\
\hline $6^{\prime}$ & 17.1 & 20.9 & 20.8 & 21.1 & 20.7 & 21.1 \\
\hline 7 & 133.4 & 134.7 & 134.0 & 134.3 & 132.2 & 133.9 \\
\hline 8 & 130.6 & 128.0 & 127.5 & 128.4 & 127.4 & 128.8 \\
\hline 9 & 72.4 & 72.4 & 71.4 & 72.3 & 70.5 & 72.4 \\
\hline 10 & 78.0 & 71.9 & 71.4 & 71.9 & 70.0 & 72.2 \\
\hline 11 & 69.8 & 79.8 & 79.2 & 79.8 & 78.0 & 80.0 \\
\hline 12 & 29.8 & 33.2 & 32.9 & 33.4 & 31.6 & 33.2 \\
\hline 13 & 69.6 & 77.3 & 76.5 & 77.3 & 75.6 & 77.8 \\
\hline 14 & 81.1 & 86.5 & 85.9 & 86.6 & 84.7 & 86.6 \\
\hline 15 & 66.3 & 70.3 & 70.0 & 70.1 & 67.9 & 70.3 \\
\hline 16 & 39.2 & 41.8 & 41.5 & 41.9 & 40.6 & 42.0 \\
\hline 17 & 27.9 & 29.8 & 29.4 & 29.5 & 27.6 & 29.2 \\
\hline $17^{\prime}$ & 20.7 & 21.0 & 21.2 & 21.1 & 20.4 & 20.8 \\
\hline 18 & 134.3 & 131.1 & 130.8 & 131.1 & 129.4 & 131.1 \\
\hline 19 & 131.7 & 136.2 & 136.0 & 136.3 & 134.7 & 136.5 \\
\hline $19^{\prime}$ & 11.5 & 14.6 & 14.4 & 14.8 & 14.3 & 15.0 \\
\hline 20 & 72.5 & 75.1 & 75.1 & 75.0 & 71.7 & 74.7 \\
\hline 21 & 41.6 & 39.6 & 39.1 & 39.7 & 38.2 & 39.8 \\
\hline $21^{\prime}$ & 10.4 & 9.4 & 10.1 & 9.9 & 8.6 & 10.4 \\
\hline 22 & 74.8 & 73.4 & 73.2 & 73.3 & 70.3 & 73.4 \\
\hline 23 & 38.4 & 33.0 & 32.9 & 33.1 & 31.3 & 33.3 \\
\hline $23^{\prime}$ & 15.7 & 13.3 & 13.7 & 13.7 & 12.9 & 14.0 \\
\hline 24 & 32.6 & 40.0 & 39.5 & 40.2 & 38.8 & 40.4 \\
\hline 25 & 53.0 & 63.0 & 63.5 & 63.9 & 63.3 & 64.8 \\
\hline 26 & 80.3 & 75.1 & 74.4 & 74.8 & 72.9 & 75.1 \\
\hline 27 & 65.5 & 64.6 & 64.2 & 64.7 & 63.0 & 65.0 \\
\hline
\end{tabular}


Synthesis of a Diastereomer of the Marine Macrolide Lytophilippine A

Table SI-1-9. ${ }^{13} \mathrm{C}$ NMR chemical shift deviation $(\Delta \delta)$ in different solvents for synthetic $(11 R, 13 S, 14 R, 15 R)$-lytophilippine A (1b).

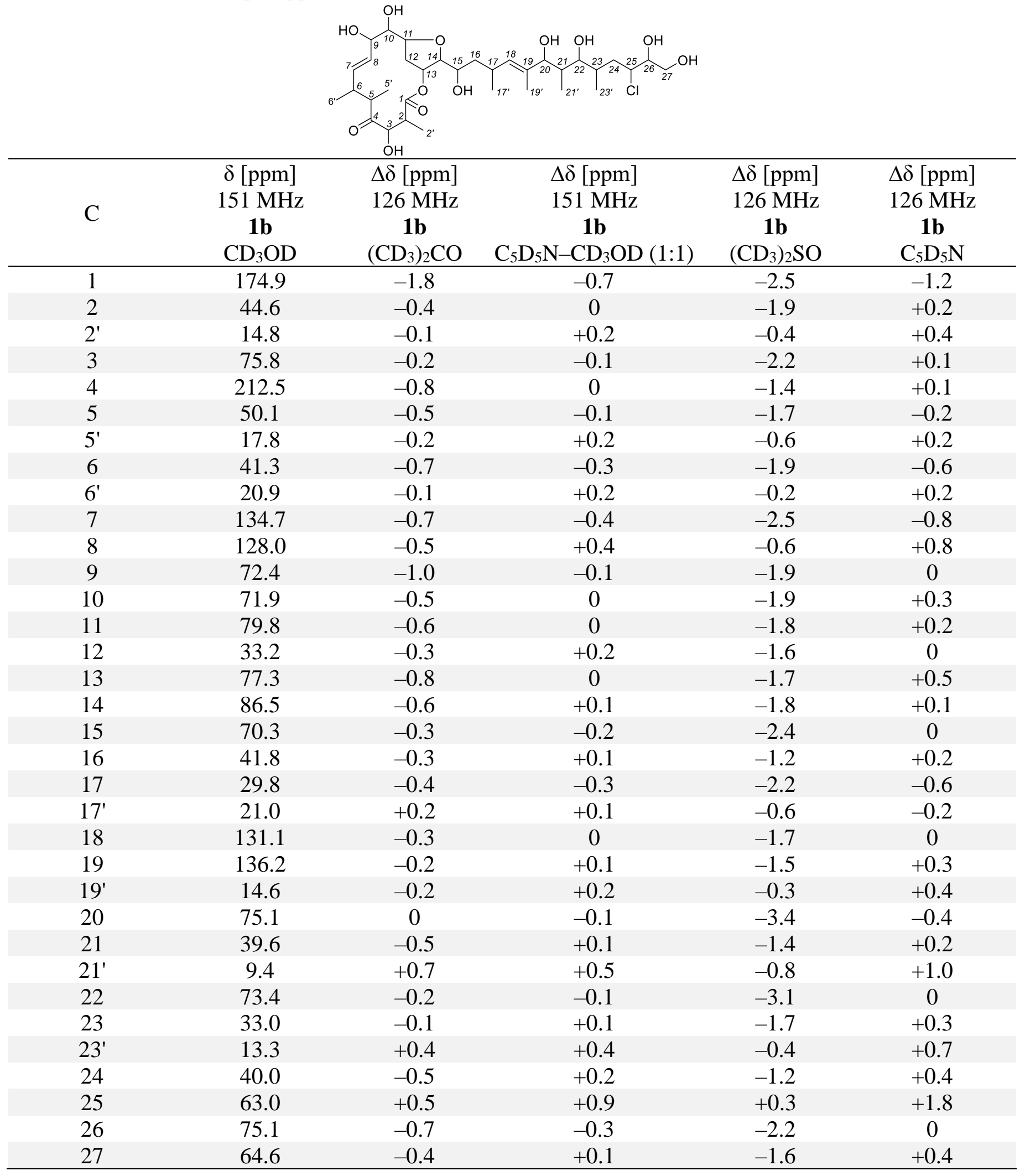


Figure SI-1-8. Comparison of ${ }^{1} \mathrm{H}$ NMR data for the molecule named "lytophilippine A" in different solvents using the data basis tabulated in Table SI-1-6: $\Delta \delta[\mathrm{ppm}]=\delta($ Rezanka, $500 \mathrm{MHz})-$ $\delta$ (Hiersemann, $600 \mathrm{MHz}, 500 \mathrm{MHZ}, 600 \mathrm{MHz}, 500 \mathrm{MHz}, 500 \mathrm{MHz}$ ). Note that the solvent used for the NMR experiments by Řezanka et al. was not reported.

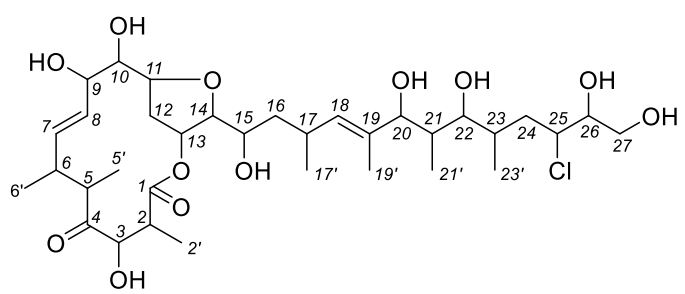

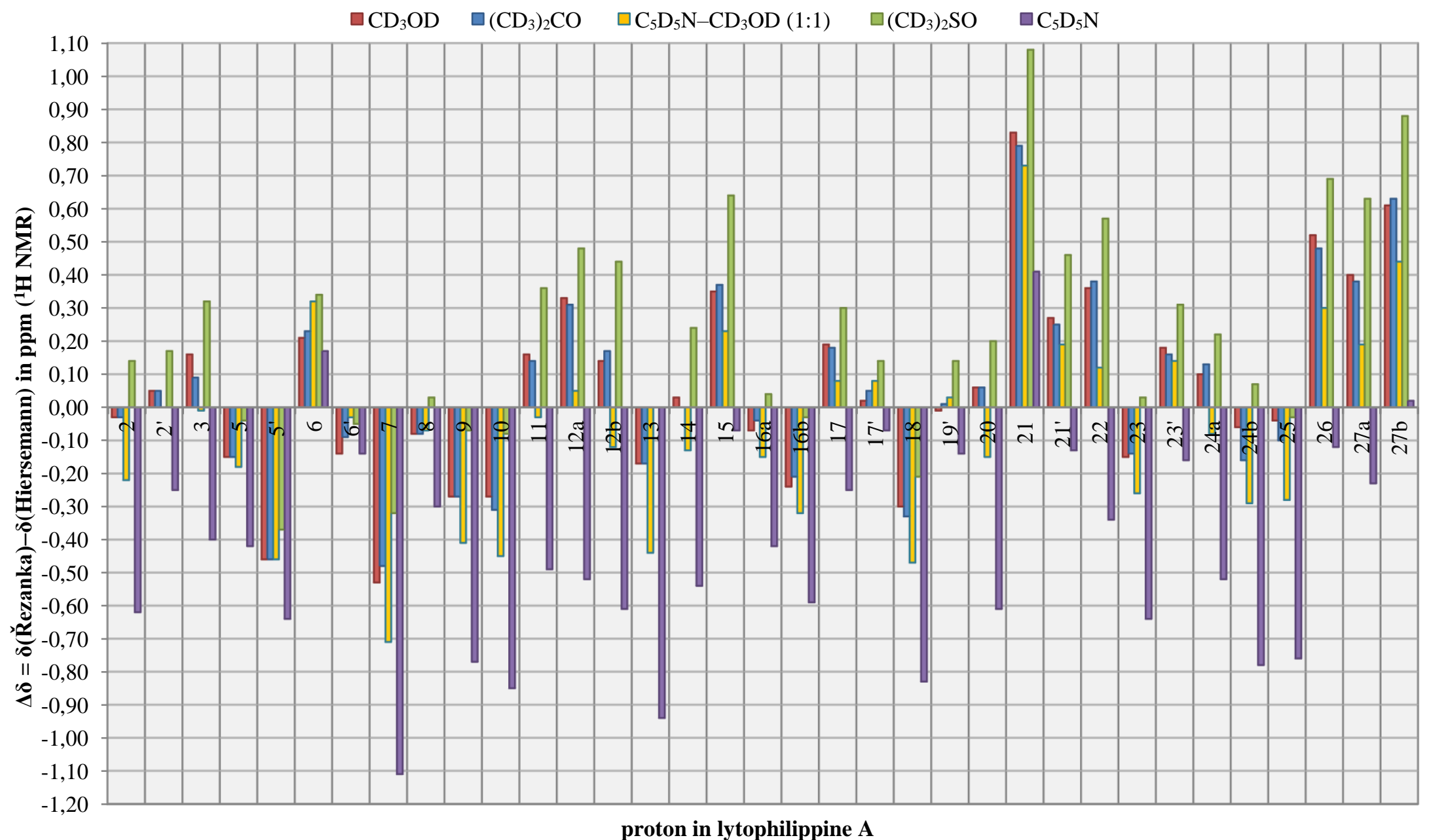


Figure SI-1-9. Comparison of ${ }^{1} \mathrm{H}$ NMR data for the molecule named "lytophilippine A" in $\mathrm{CD}_{3} \mathrm{OD}$ using the data basis tabulated in Table SI-1-6: $\Delta \delta[\mathrm{ppm}]=\delta($ Rezanka, $500 \mathrm{MHz})-\delta($ Hiersemann, $600 \mathrm{MHz})$ and $\Delta \delta[\mathrm{ppm}]=\delta(\check{\mathrm{R} e z a n k a}, 500 \mathrm{MHz})-\delta($ Lee, $600 \mathrm{MHz})$. Note that the solvent used for the NMR experiments by Rezanka et al. was not reported.

$$
\begin{aligned}
& \overbrace{9}^{\mathrm{HO}_{10}^{11}}
\end{aligned}
$$

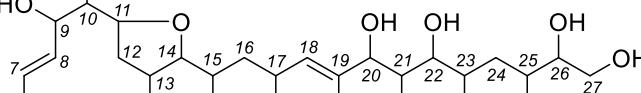

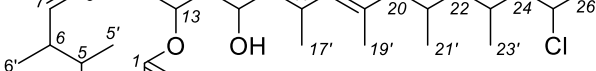

$$
\begin{aligned}
& \overbrace{}^{4} \overbrace{}^{2}
\end{aligned}
$$

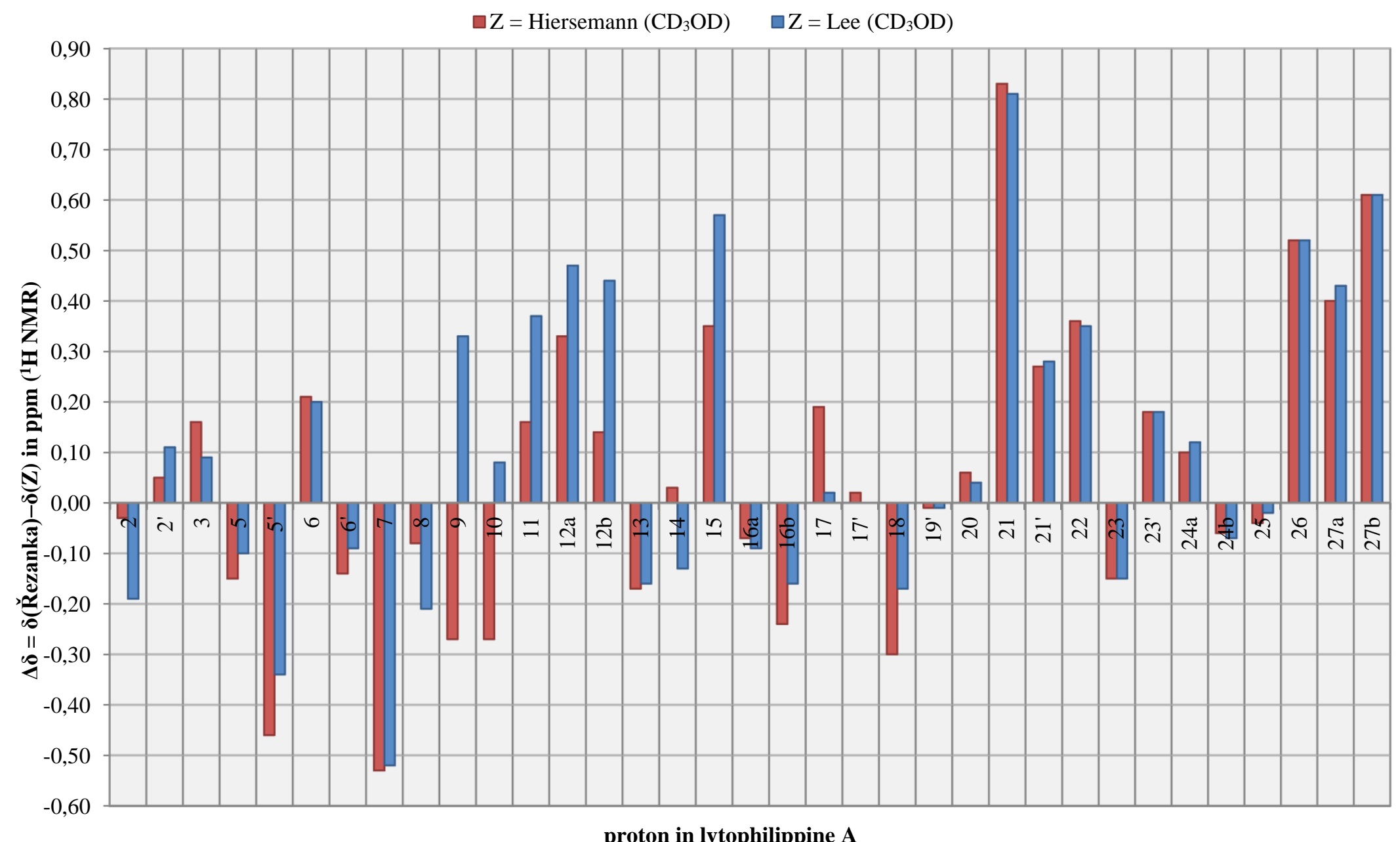


Figure SI-1-10. Comparison of "H NMR data for the molecule named "lytophilippine $\mathrm{A}$ " in $\mathrm{CD}_{3} \mathrm{OD}$ using the data basis tabulated in Table SI-1-6: $\Delta \delta[\mathrm{ppm}]=\delta($ Lee, $600 \mathrm{MHz})-$ $\delta($ Hiersemann, $600 \mathrm{MHz})$.
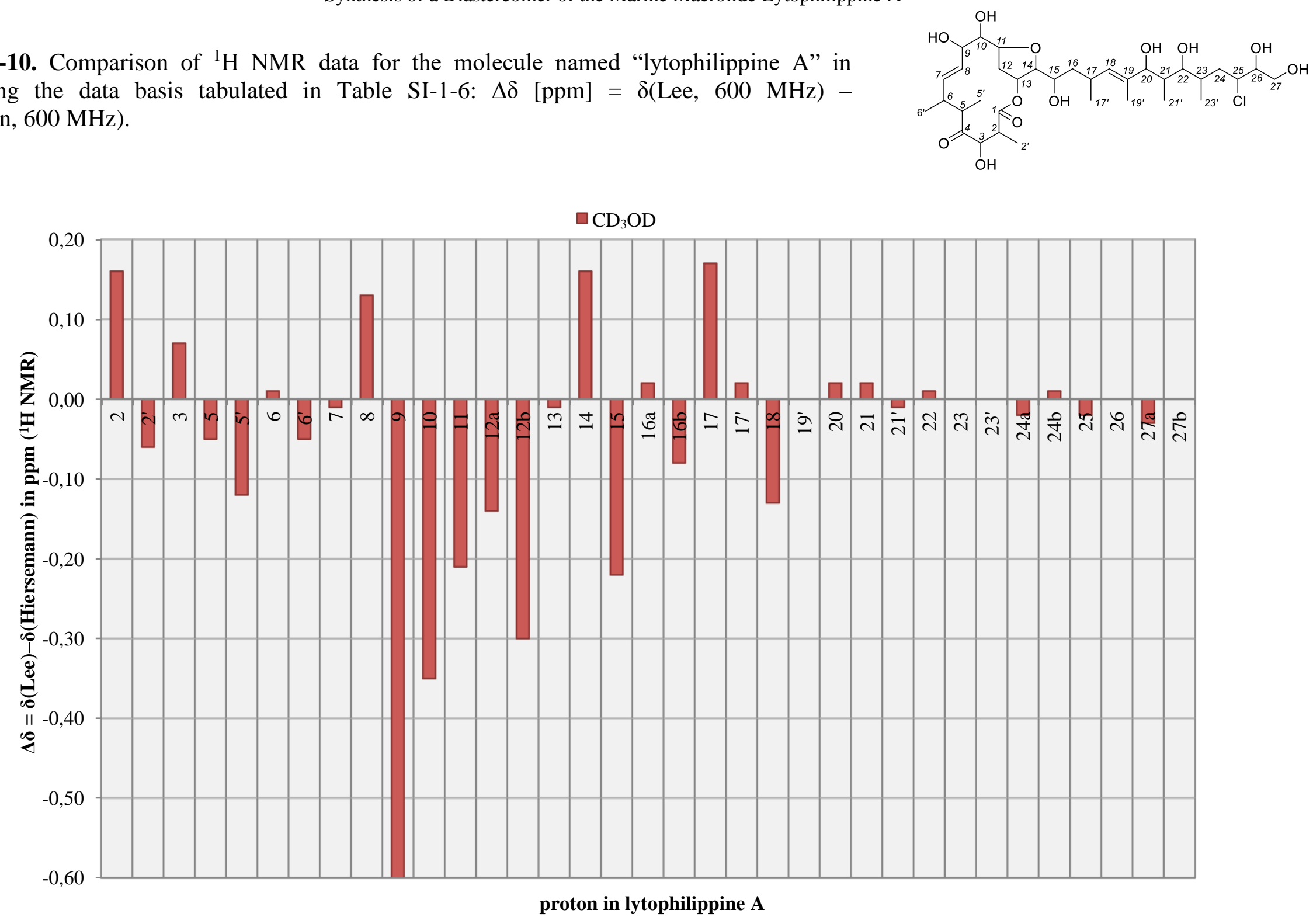
Figure SI-1-11. Comparison of ${ }^{13} \mathrm{C}$ NMR data for the molecule named "lytophilippine $\mathrm{A}$ " in different solvents using the data basis tabulated in Table SI-1-7: $\Delta \delta[\mathrm{ppm}]=\delta($ Rezanka, $126 \mathrm{MHz})$

- $\delta$ (Hiersemann, $151 \mathrm{MHz}, 126 \mathrm{MHz}, 151 \mathrm{MHz}, 126 \mathrm{MHz}, 126 \mathrm{MHz}$ ). Note that the solvent used for the NMR experiments by Rezanka et al. was not reported.

$$
\begin{aligned}
& \text { HO } \overbrace{9}^{\mathrm{OH}}{ }^{11}
\end{aligned}
$$

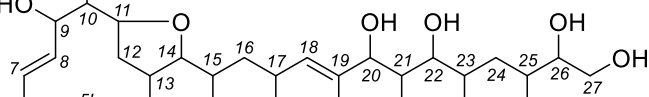

$$
\begin{aligned}
& 6^{6} 5^{5^{\prime}} \mathrm{O}^{\mathrm{O}} \mathrm{OH} \quad \mathrm{17}^{\prime} Y_{19^{\prime}} Y_{21^{\prime}} Y_{23^{\prime}} \mathrm{Cl} \\
& \overbrace{}^{4}{ }^{2}
\end{aligned}
$$

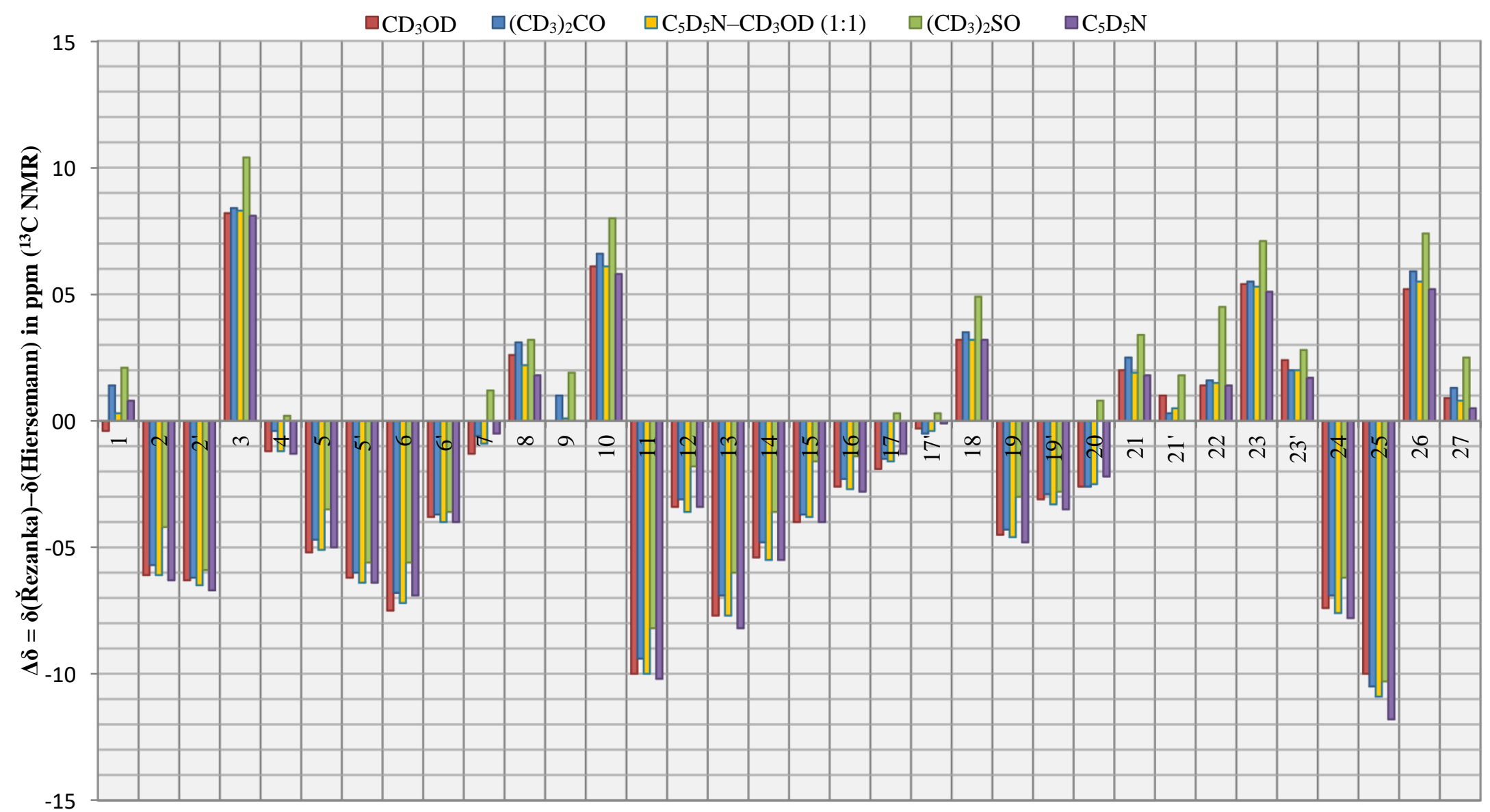

carbon atom in lytophilippine A 


\section{References}

${ }^{1}$ Frigerio, M.; Santagostino, M.; Sputore, S. J. Org. Chem. 1999, 64, 4537.

${ }^{2}$ Corey, E. J.; Cho, H.; Rucker, C.; Hua, D. H. Tetrahedron Lett. 1981, 22, 3455.

3 (a) Miescher, K. Helv. Chim. Acta 1946, 29, 743. (b) Miescher, K.; Kägi, H. Helv. Chim. Acta 1949, 32, 761. (c) Stahl, E.; Kaltenbach. U. J. Chromatogr. 1961, 5, 351.

${ }^{4}$ Still, W. C.; Kahn, M.; Mitra, A. J. Org. Chem. 1978, 43, 2923.

${ }^{5}$ Gottlieb, H. E.; Kotlyar, V.; Nudelman, A. J. Org. Chem. 1997, 62, 7512.

${ }^{6}$ Cho, B. H.; Kim, J. H.; Jeon, H. B.; Kim, K. S. Tetrahedron 2005, 61, 4341.

${ }^{7}$ Tanaka, A.; Yamashita, K. Synthesis 1987, 6, 570.

${ }^{8}$ Jang, K. P.; Choi, S. Y.; Chung, Y. K.; Lee, E. Org. Lett. 2011, 13, 2476.

${ }^{9}$ Börding, S.; Strohmann, C.; Preut, H.; Hiersemann, M. Acta Cryst. 2012, E68, o169.

${ }^{10}$ Evans, D. A.; Weber, A. E. J. Am. Chem. Soc. 1986, 108, 6757.

${ }^{11}$ McKennon, M. J.; Meyers, A. I.; Drauz, K.; Schwarm, M. J. Org. Chem. 1993, 58, 3568.

${ }^{12}$ Abiko, A.; Simons, L. J.; Roush, W. R. Org. Synth. 2002, 79, 109.

13 Abiko, A.; Flamme, E. M.; Roush, W. R. Org. Synth. 2002, 79, 103.

${ }^{14}$ Evans, D. A.; Bartroli, J., Shih, T. L. J. Am. Chem. Soc. 1981, 103, 2127.

${ }^{15}$ Evans, D. A.; Ennis, M. D.; Mathre, D. J. J. Am. Chem. Soc. 1982, 104, 1737.

${ }^{16}$ Gille, A.; Hiersemann, M. Org. Lett. 2010, 12, 5258.

${ }^{17}$ Lin, N.; Overman, L. E.; Rabinowitz, M. H.; Robinson, L. A.; Sharp, M. J.; Zablocki, J. J. Am. Chem. Soc. 1996, 118, 9062.

${ }^{18}$ Moon, H. R.; Choi, W. J.; Kim, H. O.; Jeong, L. S. Tetrahedron: Asymmetry 2002, 13, 1189.

${ }^{19}$ Dale, J. A.; Mosher, H. S. J. Am. Chem. Soc. 1973, 95, 512.

20 a) Rychnovsky, S. D.; Skalitzky, D. J. Tetrahedron Lett. 1990, 31, 945. b) Rychnovsky, S. D.; Rogers, B. N.; Richardson, T. I. Acc. Chem. Res. 1998, 31, 9.

${ }^{21}$ Řezanka, T.; Hanuš, L. O.; Dembitsky, V. M. Tetrahedron 2004, 60, 12191. 